\title{
CARACTERÍSTICAS MORFOLÓGICAS E QUANTITATIVAS DOS PLEXOS VISCERAIS: ASPECTOS NORMAIS E FATORES MODIFICADORES
}

Apresentada ao Instituto de Ciências Biomédicas

da Universidade de São Paulo para a obtenção do

título de Livre-Docente em Ciências (Anatomia)

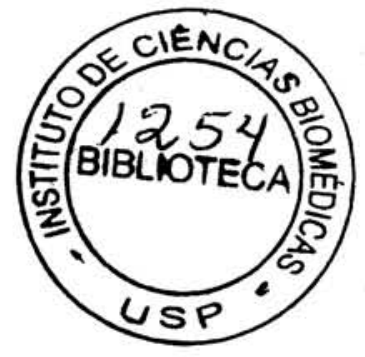

SÃO PAULO

1996 
FICHA CATALOGRÁFICA

Preparada pela Biblioteca do

Instituto de Ciências Biomédicas da Universidade de São Paulo

T - I CB Liberti, Edson Aparecido.

BMA

Caracteristicas morfológicas e quantitativas dos plexos viscerais:

L695C aspectos normais e fatores modificadores / Edson Aparecido Liberti -

1996 São Paulo, 1996.

Tese (Livre-docência)-Instituto de Ciências Biomédicas da Universidade de São Paulo. Departamento de Anatomia.

Área de concentração: Anatomia.

Descritores: 1.Sistema nervoso autônomo 2.Plexos entéricos 3.Plexo mientérico 4.Plexo submucoso 5.Envelhecimento 6.Desnutrição.

ICB/SBIB.011/95 
Nunca procedí tão bem como desejacia ter procedido. Mas fiz o melhor que pude, com franqueza e com retidão. Não posso mais do que isso. $-\mathcal{E}$ não tenho 0 direito de fazer menos.

(Cunha Bueno) 
A meus pais e sogros

Acreditai na lembrança eterna de vossos antepassados e na gratidão imperecivel dos vindouros. (B. Montenegro)

\section{Ao Leonardo}

A maior felicidade que existe é a silenciosa certeza de que vale a pena viver. (Amyr Klink)

\section{À Vera Lúcia}

Compreender é muitas vezes dificil. Compreender e apoiar é a forma verdadeira de amar...tudo.

\section{Ao Dr. Cláudio}

A coragem e a esperança morrem e renascem muitas vezes. A dignidade e o respeito morrem uma única vez.

\section{Ao "Miltão"}

Que é o homem, e para que presta ele? $\mathrm{E}$ que bem ou que mal pode ele fazer? (Eclesiástico, XVII, 7) 


\section{AGRADECIMENTOS}

Aos meus amigos docentes, funcionários e alunos do Departamento de Anatomia e do Instituto de Ciências Biomédicas da Universidade de São Paulo, pela solidariedade, carinho e imensa bondade com que sempre me trataram. 


\section{SUMÁRIO}

Apresentação

Resumo

1. INTRODUÇÃO ….................................................................. 1

2. OBJETIVOS

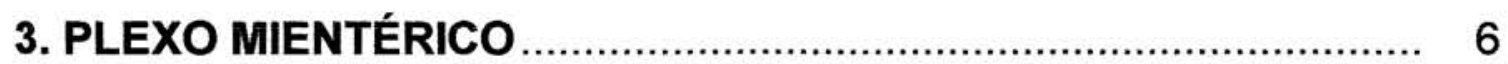

Características gerais .............................................................. 6

Morfologia dos gânglios e neurônios ................................ 6

Densidade neuronal e área do perfil celular ....................... 8

Efeitos do envelhecimento......................................................... 13

Efeitos da doença de Chagas....................................................... 16

Efeitos da desnutrição .............................................................. 17

4. PLEXO SUBMUCOSO.................................................................. 20

Características gerais ............................................................. 21

Morfologia dos gânglios e neurônios ................................. 21

Densidade neuronal e área do perfil celular ...................... 22

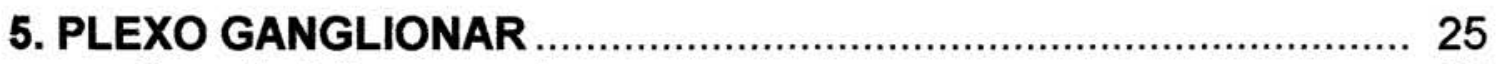

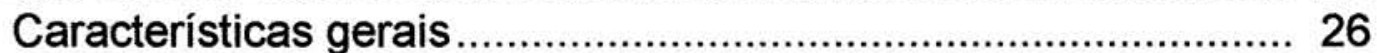

Morfologia dos gânglios e neurônios ................................ 26

Densidade neuronal e área do perfil celular ..................... 27

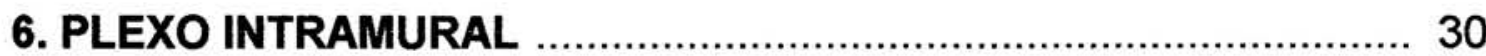

Características gerais ........................................................ 30

Morfologia dos gânglios e neurônios .................................... 30

Densidade neuronal e área do perfil celular ...................... 31

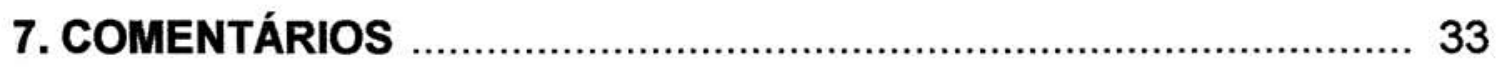

8. TRABALHOS QUE DERAM ORIGEM À TESE ............................ 39

9. REFERÊNCIAS BIBLIOGRÁFICAS .......................................... 41

Abstract

Separatas 


\section{APRESENTAÇÃo}

De acordo com as normas que regem o Concurso para a obtenção do título de Livre-Docência dos Departamentos do Instituto de Ciências Biomédicas da Universidade de São Paulo onde o candidato poderá apresentar como tese texto que sistematize criticamente sua obra ou parte dela, submetemos à apreciação da Comissão Julgadora a presente coletânea, elaborada a partir de estudos morfoquantitativos sobre os plexos viscerais, desenvolvidos no "Laboratório de Sistema Nervoso Autônomo" do Departamento de Anatomia do Instituto de Ciências Biomédicas da Universidade de São Paulo.

Muitos trabalhos e teses foram e estão sendo realizados nesse setor do Departamento, caracterizando uma linha de pesquisa bem estabelecida que conta com uma disciplina no curso de Pós-graduação (BMA- 796 - Anatomia do Sistema Nervoso Entérico) ministrada regularmente no segundo semestre do ano letivo, desde 1991. 


\section{Resumo}

A morfologia normal, as alterações determinadas pelo envelhecimento, a doença de Chagas e a desnutrição e os aspectos evolutivos dos plexos viscerais em diferentes espécies animais são os objetivos da presente linha de pesquisa.

O plexo mientérico é constituído por gânglios de tamanho e formas variadas de acordo com a região do tubo digestivo e a espécie estudada. Uma cápsula de tecido conjuntivo envolve os gânglios, sendo bem desenvolvida no plexo mientérico das diversas regiões do tubo digestivo humano. No interior dos gânglios, predominam neurônios ovalados ou arredondados, bem como uma grande quantidade de células satélites. A densidade neuronal aumenta no tubo digestivo no sentido crânio-caudal. No homem, os neurônios maiores são observados no esôfago.

Neurônios de contorno alterado estão presentes nos gânglios mientéricos de indivíduos idosos. A densidade neuronal diminui com o envelhecimento e, especificamente no homem, a densidade dos componentes fibrosos ganglionares aumenta. A perda neuronal é verificada para todos os neurônios em relação ao tamanho, isto é, o envelhecimento determina uma diminuição das diversas populações dos neurônios mientéricos.

$\mathrm{Na}$ doença de Chagas também ocorre uma diminuição da densidade neuronal do plexo mientérico. A área média dos neurônios de animais infectados diminui, caracterizando a perda de um tipo específico de população neuronal.

Uma grande quantidade de neurônios imaturos é verificada no plexo mientérico de animais desnutridos. Além disso, a desnutrição determina a redução da média do corpo dos neurônios mientéricos. 
As malhas do plexo submucoso são irregulares quando comparadas às do plexo mientérico. Seus gânglios são pequenos e dispersos, e a área dos neurônios é menor quando comparada à área dos neurônios do plexo mientérico da mesma região. A densidade neuronal é maior no duodeno, ocorrendo uma proporção constante de 2,5 a 4 neurônios do plexo mientérico para cada neurônio do plexo submucoso em uma mesma região do intestino.

O plexo ganglionar caracteriza-se por apresentar gânglios pequenos, semelhante ao observado no plexo submucoso. A densidade neuronal neste plexo é baixa, e a área média dos neurônios da traquéia e da vesícula biliar é maior que a verificada para os neurônios do plexo submucoso.

$\mathrm{Na}$ bexiga urinária, a quantidade, o arranjo e a distribuição dos neurônios do plexo intramural diferem de acordo com a espécie animal, levando a crer que o meio ambiente seja um fator determinante na diversidade do plexo verificada em animais da mesma ordem. O agrupamento dos neurônios em gânglios cada vez maiores, com a conseqüente elevação na densidade neuronal, parece ser uma tendência evolutiva. 


\section{1- INTRODUÇÃo}

No homem, os intestinos anterior, médio e posterior, originados a partir do intestino primitivo, são identificados na quarta semana de vida intrauterina derivando destas três divisões, vísceras da porção inferior do sistema respiratório, do tubo digestivo e do seio urogenital.

Duas teorias têm sido postuladas a fim de se estabelecer a origem da inervação dessas estruturas. De acordo com a teoria clássica, antes da décimasegunda semana de vida intra-uterina, ocorre, em sentido crânio-caudal, uma migração simples dos neuroblastos entéricos vagais ao longo do intestino (OKAMOTO \& UEDA, 1967). A segunda teoria descreve um aparecimento simultâneo de populações de neuroblastos em ambas as extremidades do intestino primitivo, que migram em direção ao intestino médio (VAOS \& LISTER, 1988; VAOS, 1989).

Os neuroblastos atingem a superficie externa das vísceras em desenvolvimento para formarem os gânglios viscerais, sendo que no tubo digestivo, envolvem a musculatura circular antes do início do desenvolvimento da musculatura longitudinal (SMITH \& TAYLOR, 1972).

Intimamente relacionados às vísceras, os gânglios constituem estruturas nervosas expostas a uma potente ação mecânica e deformações durante a atividade motora visceral.

Conectados por feixes de fibras interganglionares, formam extensos plexos distribuídos ao longo da parede das vísceras, denominados de acordo com o órgão em que se situam. Assim, os plexos encontrados na traquéia e na vesícula biliar são denominados plexos ganglionares (CAI \& GABELLA, 1983a; CHIANG \& GABELLA, 1986); o plexo existente na bexiga urinária é conhecido como plexo intramural (GABELLA, 1990a).

Particularmente em relação ao tubo digestivo, os plexos responsáveis pela inervação de suas camadas muscularis externa e muscularis mucosae 
constituem o "Sistema Nervoso Entérico" (LANGLEY, 1921), formado pelo plexo mientérico ou de AUERBACH (1864) situado entre as camadas longitudinal e circular da muscularis externa, e o plexo submucoso ou de MEISSNER (1857), situado na tela submucosa.

A visão geral dos plexos viscerais na literatura, é a de que são estruturas estáticas e bem delimitadas. $\mathrm{Na}$ realidade, são estruturas plásticas e desta forma altamente dinâmicas, muito embora este interessante aspecto biológico não tenha sido ainda sistematicamente estudado (GABELLA, 1989).

Os plexos viscerais alteram sua forma e arquitetura durante a contração e o relaxamento da musculatura adjacente (GABELLA, 1990b), sofrendo também amplas mudanças em sua composição durante o crescimento do animal onde existe um extenso desenvolvimento estrutural durante a vida pósnatal, incluindo a formação de novos neurônios (GABELLA, 1971).

A forma e a arquitetura dos plexos variam em estrutura em diferentes vísceras (CAI \& GABELLA, 1983b; CHIANG \& GABELLA, 1986; GABELLA, 1990b) e partes do tracto gastro-intestinal e em diversas espécies animais (IRWIN, 1931; OHKUBO, 1936a,b; SAUER \& RUMBLE, 1946; FILOGAMO \& VIGLIANI, 1954; BALUK \& GABELLA, 1987, 1989), alterando-se ainda em diferentes patologias (KÖBERLE, 1962, YOSHIDA et al., 1988, OLIVEIRA et al., 1990).

Negligenciados por um longo período, os plexos deixaram de ser considerados como constituintes de um sistema nervoso relativamente simples que controlaria um repertório limitado de comportamentos, para serem alvo de estudos cada vez mais elaborados que têm procurado examinar exaustivamente a biologia de seus componentes, com o objetivo de se elucidar os diversos aspectos relativos às funções viscerais. Além disso, os neurônios dos plexos viscerais tornaram-se um modelo atraente de sistema neurobiológico, devido ao seu fácil acesso e também ao fato de poderem sobreviver in vitro. 
As diversas características dos plexos viscerais, em geral têm sido demonstradas por métodos não histoquímicos (PALUMBI, 1933; BARBOSA, 1978), histoquímicos (GABELLA, 1969, 1976; 1979; 1990a, b) e, mais recentemente, através de técnicas imuno-histoquímicas (KRAMMER \& KÜHNEL, 1992; KRAMMER et al., 1993). O comprimento e a largura de seus gânglios são bem maiores que a espessura, permitindo que amplas extensões de um plexo possam ser observadas em preparados totais de membrana, oferecendo desta maneira, possibilidades atraentes para a investigação, particularmente aquelas relativas à sua forma e disposição geral de seus componentes, bem como aos aspectos quantitativos. Assim, a maior parte dos conhecimentos sobre a densidade espacial dos neurônios ganglionares foi obtida através de estudos realizados em preparados totais (TAFURI, 1957; GABELLA, 1971, 1987a; FERRAZ DE CARVALHO et al., 1983, CAI \& GABELLA, 1984; GABELLA \& TRIGG, 1984; SANTER \& BAKER, 1988), pois permitem obter estimativas de densidade mais confiáveis, evitando a necessidade de extrapolações estatísticas e outros incovenientes decorrentes da utilização de cortes histológicos em estudos quantitativos, como a contagem repetida de neurônios.

Estudos sobre a morfologia dos plexos e seus constituintes, bem como a avaliação da densidade e da área do perfil neuronais, são considerados importantes para a determinação dos padrões normais de inervação específicos para cada víscera em um tipo de animal ou em diferentes grupos de animais, fornecendo dados que constituem um substrato morfológico decisivo para interpretações das inúmeras funções viscerais. Tais informações podem ser obtidas através da análise evolutiva desses plexos, que comprovadamente são estruturas sujeitas a processos adaptativos decorrentes de vários fatores, ambientais ou alimentares, como descrito por CHRINTENSEN et al. (1984), que ao estudar a inervação da parte distal do colo em oito diferentes espécies animais, verificou 
desde um plexo mientérico bem desenvolvido em algumas espécies, até sua completa ausência, em outras.

Além disso, ao se estabelecer as características morfológicas normais dos plexos nervosos, as alterações decorrentes de diversas patologias podem também ser padronizadas, servindo como base morfológica essencial para a compreensão de diferentes distúrbios funcionais que acometem as vísceras. 


\section{2- OBJETIVOS}

Considerando-se a importância da atuação dos plexos na complexa fisiologia das vísceras em que se situam, a presente linha de pesquisa tem por objetivos analisar:

1- As características morfológicas normais dos plexos viscerais nas diferentes estruturas oriundas dos primórdios do intestino humano, observando as possíveis semelhanças e diferenças entre esses plexos;

2- Os aspectos evolutivos dos plexos viscerais em diversas espécies animais;

3- As alterações dos plexos viscerais determinadas por agentes modificadores como o envelhecimento, a desnutrição e a doença de Chagas. 


\section{3- PLEXO MIENTÉRICO}

Dentre os plexos viscerais, o plexo mientérico tem sido o mais estudado, especialmente quanto aos aspectos quantitativos (GUNN, 1959; LEAMING \& CAUNA, 1961). Entretanto, ainda que existam muitos trabalhos sobre a densidade de seus neurônios em diversas espécies como o rato (GABELLA, 1979), o camundongo (TAFURI, 1957), o coelho (MASLENNIKOVA, 1962), o gato (SAUER \& RUMBLE, 1946), o cão (FILOGAMO \& VIGLIANI, 1954) e o macaco (OHKUBO, 1936b), os dados são menos extensivos que os obtidos para o plexo mientérico de algumas espécies como a cobaia, onde a densidade de todas as partes de seu tubo digestivo foi amplamente determinada (GABELLA, 1987b).

Por outro lado, pesquisas sobre a densidade neuronal em espécies de grande porte como o homem são escassas, destacando-se as descrições de GABELLA (1987a) sobre o intestino delgado do carneiro, e de BURNS \& CUMMINGS (1991) no tubo digestivo do cavalo. Outras espécies menos conhecidas, mas que devido à sua importância em determinadas patologias que acometem o homem vêm sendo sistematicamente estudadas nos últimos tempos, não são referidas em estudos dos plexos em geral. É o caso específico do Calomys callosus, importante modelo de laboratório para estudos sobre os efeitos da moléstia de Chagas em diversos órgãos do animal, além do coração.

\section{Características gerais}

\section{Morfologia dos gânglios e neurônios}

Em nossas pesquisas, observamos que os gânglios do plexo mientérico, unidos por feixes de fibras interganglionares apresentam diferentes formas e estão dispostos de várias maneiras, de acordo com a região do tubo digestivo e a espécie animal considerada. Os gânglios e feixes nervosos encontram- 
se incluídos no delgado septo conjuntivo situado entre os dois estratos da muscularis externa. Em algumas espécies, histologicamente, cada gânglio apresenta-se envolvido por uma cápsula de tecido conjuntivo, de onde se destacam delgadas lâminas contínuas com as lâminas de tecido conjuntivo que envolvem os feixes musculares; no interior do gânglio, esse tecido forma envoltórios para cada neurônio ou para grupamentos neuronais (Figs. 1a, b).

No colo humano (TRAB. I), análises feitas em cortes histológicos corados com Picro Sirius sob luz polarizada, demonstram a presença de uma cápsula ganglionar, constituida predominantemente por fibras colágenas do Tipo I (Figs. 1c-e). Além disso, colarações específicas para fibras do sistema elástico, permitem observar a presença desse tipo de fibras tanto na cápsula como no interior dos gânglios (Fig 1f). Tais observações são confirmadas pela análise ultraestrutural (Figs. 1g, h).

Nos preparados totais de membrana, observamos no intestino delgado da cobaia (TRAB. II) que os gânglios são longos e delgados nas regiões correspondentes ao jejuno e ao íleo, não ultrapassando em média 4 neurônios de espessura (Fig. 2a); no duodeno, mesmo que alguns gânglios sigam esse padrão, a maioria apresenta-se com formato triangular, quadrado, retangular, arredondado ou ovalado, sendo seu comprimento aproximadamente a metade do observado para as outras regiões (Figs. 2b, c). Essa particularidade do plexo mientérico do duodeno da cobaia permite determinar o limite do gânglio, o que não é possível quando se trata do jejuno e do íleo, pois devido a sua grande extensão, os gânglios normalmente se unem em suas extremidades.

Os gânglios do plexo mientérico do intestino delgado do Calomys callosus, um roedor silvestre muito comum na América do Sul e descrito no Brasil como hospedeiro do Trypanosoma cruzi assemelham-se aos observados no jejuno e no íleo da cobaia, porém com um tamanho menor (TRAB. III). O longo eixo dos gânglios é paralelo à camada circular da muscularis externa, semelhante ao que 
ocorre na cobaia (Fig. 2d). No rato (TRAB. IV), os gânglios do intestino delgado formam verdadeiros cordões alongados paralelos à camada circular, dispostos em intervalos regulares, e contínuos entre sí (Fig. 2e).

O plexo mientérico do intestino delgado humano (TRAB. V) apresenta gânglios que variam em forma e tamanho, sendo observados desde gânglios com alguns poucos neurônios até gânglios com elevado número de células. Como verificamos no duodeno da cobaia, os gânglios no homem apresentam-se arredondados, triangulares e ovalados (Figs. $2 \mathrm{f}, \mathrm{g}$ ).

No esôfago do Calomys callosus (Fig. 3a), os gânglios são extremamente pequenos e esparsamente distribuídos (TRAB III), o que de certa forma, pode ser considerado verdadeiro em relação ao que verificamos no esôfago humano, onde a maior parte dos gânglios foi classificada como gânglios pequenos, ou seja, contendo de 3 a 40 neurônios (TRAB. VI).

No intestino grosso humano, os gânglios são geralmente grandes, com formatos diversos (TRAB. I) e predominantemente alongados no colo do Calomys callosus (TRAB. III). Os gânglios do plexo mientérico do colo da cobaia (TRAB. VII) são os que apresentam uma maior diversidade quanto à forma, pois além de gânglios alongados, retangulares, quadrangulares, formas complexas únicas de aspecto poligonal estão também presentes (Figs. 3g, h).

A forma e dimensões assumidas pelos neurônios nas espécies que estudamos são variáveis, predominando em todas as vísceras, aqueles de aspecto ovalado e arredondado, com núcleo excêntrico. As células satélites estão presentes no interior dos gânglios, entre os neurônios, em toda a extensão do tubo digestivo (Figs. 3a-f).

\section{Densidade neuronal e área do perfil celular}

Ao analisarmos a densidade neuronal média ao longo do tubo digestivo, no sentido crânio-caudal, verificamos que no esôfago encontra-se a 
menor densidade, que é de $1.500 \mathrm{n} / \mathrm{cm}^{2}$ no Calomys callosus, muito semelhante à densidade de $1.790 \mathrm{n} / \mathrm{cm}^{2}$ observada no esôfago humano (TRABs. III, VI). No plexo mientérico das três regiões do intestino delgado da cobaia, a densidade é de 15.600 neurônios $/ \mathrm{cm}^{2}$ diminuindo para $7.100 \mathrm{n} / \mathrm{cm}^{2}$ no intestino delgado humano e $9.000 \mathrm{n} / \mathrm{cm}^{2}$ no intestino delgado do Calomys callosus (TRABs. II, III, V). A densidade neuronal no colo humano é estimada em $46.300 \mathrm{n} / \mathrm{cm}^{2}$ e em 53.397 $\mathrm{n} / \mathrm{cm}^{2}$ no colo da cobaia (TRABs. I, VII).

A área média do perfil celular, que em última análise traduz o tamanho do corpo dos neurônios é de $297 \mu \mathrm{m}^{2}$ para os neurônios do esôfago do Calomys callosus e de $579 \mu \mathrm{m}^{2}$ para os do esôfago humano (TRABs. III, VI). No estômago do Calomys callosus a área média do perfil celular é de $290 \mu \mathrm{m}^{2}$ e no homem 387 $\mu \mathrm{m}^{2}$ (TRABs. III, VIII). Os neurônios do intestino delgado da cobaia possuem uma área média de $195 \mu \mathrm{m}^{2}$ no duodeno, $185 \mu \mathrm{m}^{2}$ no jejuno e $147 \mu \mathrm{m}^{2}$ no íleo; os do Calomys callosus possuem área média de $179 \mu^{2}$ na região do jejuno, semelhante ao verificado na cobaia. Os neurônios do intestino delgado humano são maiores, com área média de $404 \mu \mathrm{m}^{2}$ (TRABs. II, III, VIII). No colo da cobaia, os corpos neuronais apresentam em média um tamanho de $248 \mu \mathrm{m}^{2}$, sendo que no colo do Calomys callosus a área é de $206 \mu \mathrm{m}^{2}$. Também no colo humano a área é maior, ou seja, $327 \mu \mathrm{m}^{2}$ (TRABs. II, III, VIII). 


\section{FIGURA 1 - Características gerais do Plexo Mientérico}

a- Corte transversal de esôfago humano passando por gânglio do plexo mientérico. Envolvendo o gânglio mientérico há uma delgada cápsula de tecido conjuntivo (seta) que se continua com aquele situado entre as fibras musculares (cabeça de seta). No interior do gânglio, delgados septos de tecido conjuntivo envolvem os neurônios $(\mathrm{N})$ (Masson. $280 \mathrm{X}$ ); b- Corte transversal do estômago de Calomys callosus onde se nota a presença de vários neurônios no interior do gânglio (setas) (Masson. 1.000 X); cCorte transversal de colo humano observado sob luz polarizada. Nota-se a presença de cápsula de tecido conjuntivo formada por colágeno tipo I (cores: amarelo, laranja) bem como fibras no interior do gânglio (setas) separando espaços que contêm neurônios (Picro sirius. $370 \mathrm{X}$ ); d- Corte transversal de colo humano analisado sem luz polarizada evidenciando um locus neuronal (N). Comparar com a figura anterior (Picro sirius. $370 \mathrm{X}$ ); e- Corte transversal de colo humano observado sob luz polarizada. Notar a espessa cápsula de tecido conjuntivo formada por colágeno tipo I (seta) e fibras de colágeno tipo III (cabeça de seta) no interior do gânglio entre os loci neuronais (Picro sirius. $715 \mathrm{X}$ ); f- Corte transversal de colo humano evidenciando tanto na cápsula (seta) como no interior do gânglio (cabeça de seta), a presença de fibras elásticas (Verhoff. 425 X); g, h- Fotomicrografias eletrônicas evidenciando fibras colágenas (C) e fibras elásticas (E) no interior dos gânglios. O citoplasma (*) bem como o núcleo do neurônio com seu nucléolo $(\mathrm{N})$ e células da glia $(\mathrm{G})$ adjacentes também são observados (g- 17000 X; h- 4300 X). 

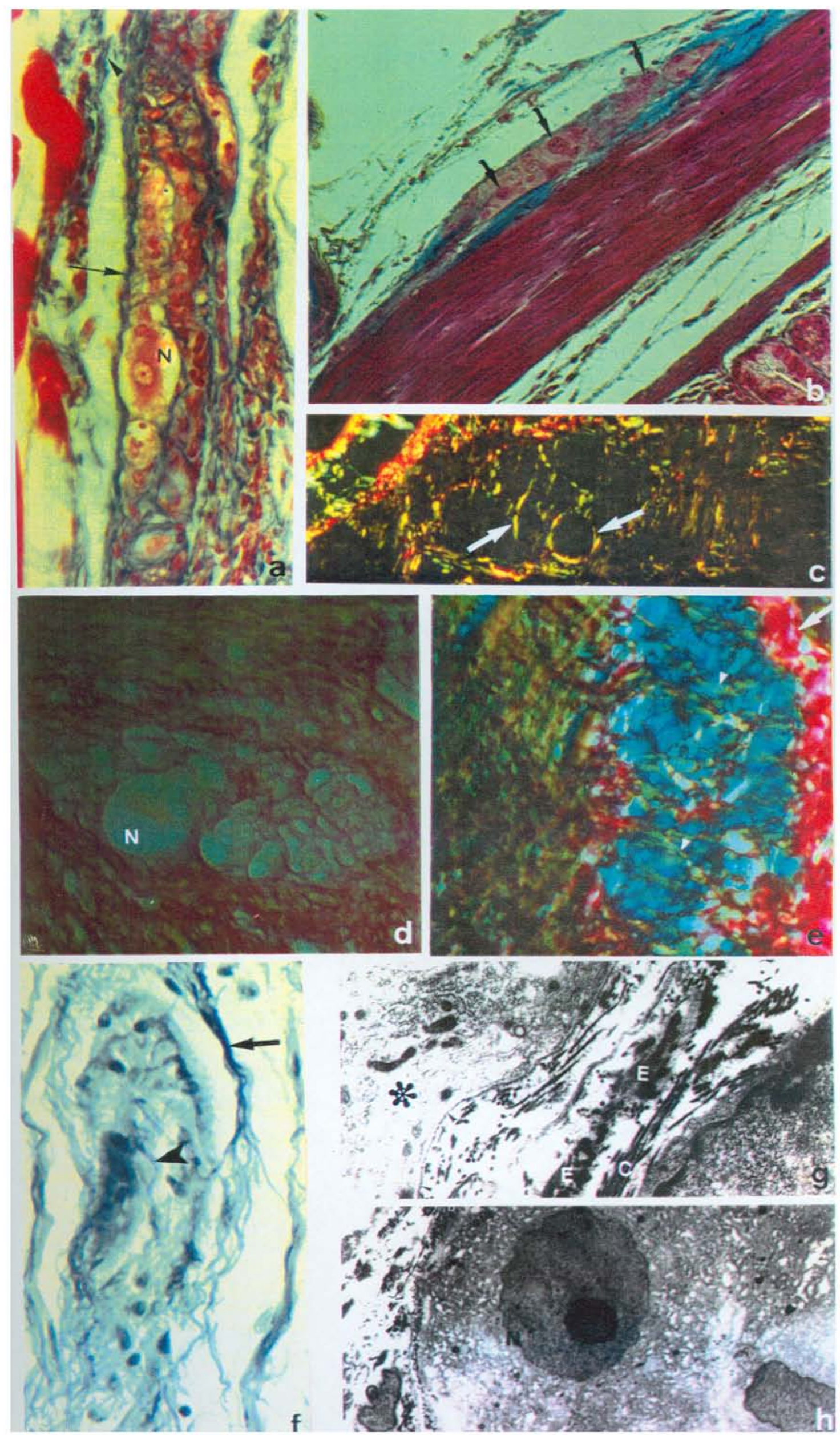

d.
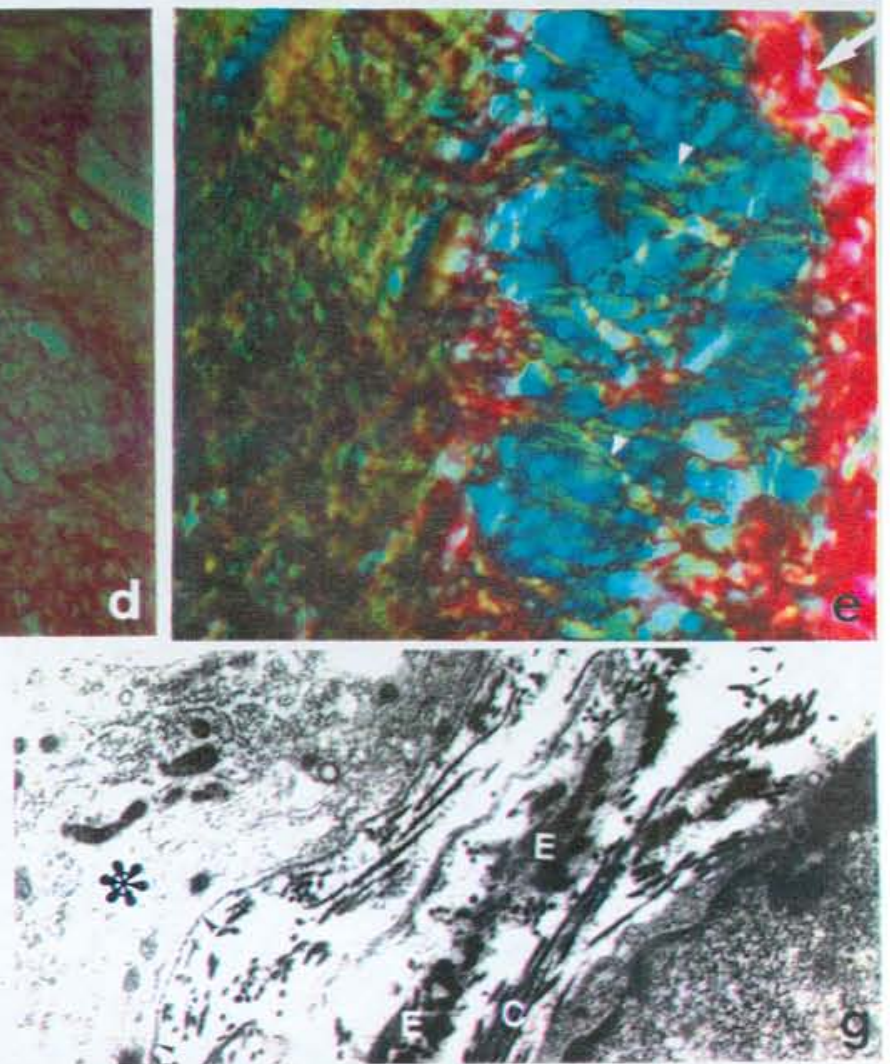

in

$f>0$.

Fis.

$\rightarrow$ cosicis

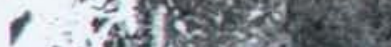

$\therefore$

int

दो

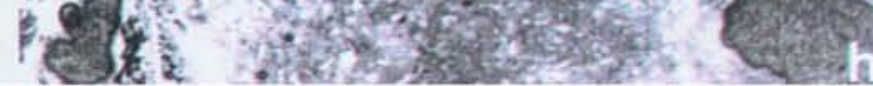




\section{FIGURA 2 - Características gerais do Plexo Mientérico}

a- Gânglio de forma alongada predominante no jejuno e no íleo da cobaia (Giemsa. $100 \mathrm{X}$ ); b, c- Outras formas de gânglios no duodeno da cobaia (Giemsa. b- 130 X; c100 X); d- Gânglio do intestino delgado do Calomys callosus contendo neurônios de diversas formas (setas) (Giemsa. 370 X); e- Gânglios do intestino delgado do rato, paralelos à musculatura circular e contínuos entre sí (NADH. $270 \mathrm{X}$ ); f- Gânglio do duodeno humano, apresentando elevada densidade neuronal. A seta indica a direção da musculatura do extrato circular (Giemsa. 95 X); g- Gânglio de tamanho médio encontrado no duodeno humano. Em maior aumento, notar a diversidade dos tamanhos e formas dos neurônios (Giemsa. 240 X). 


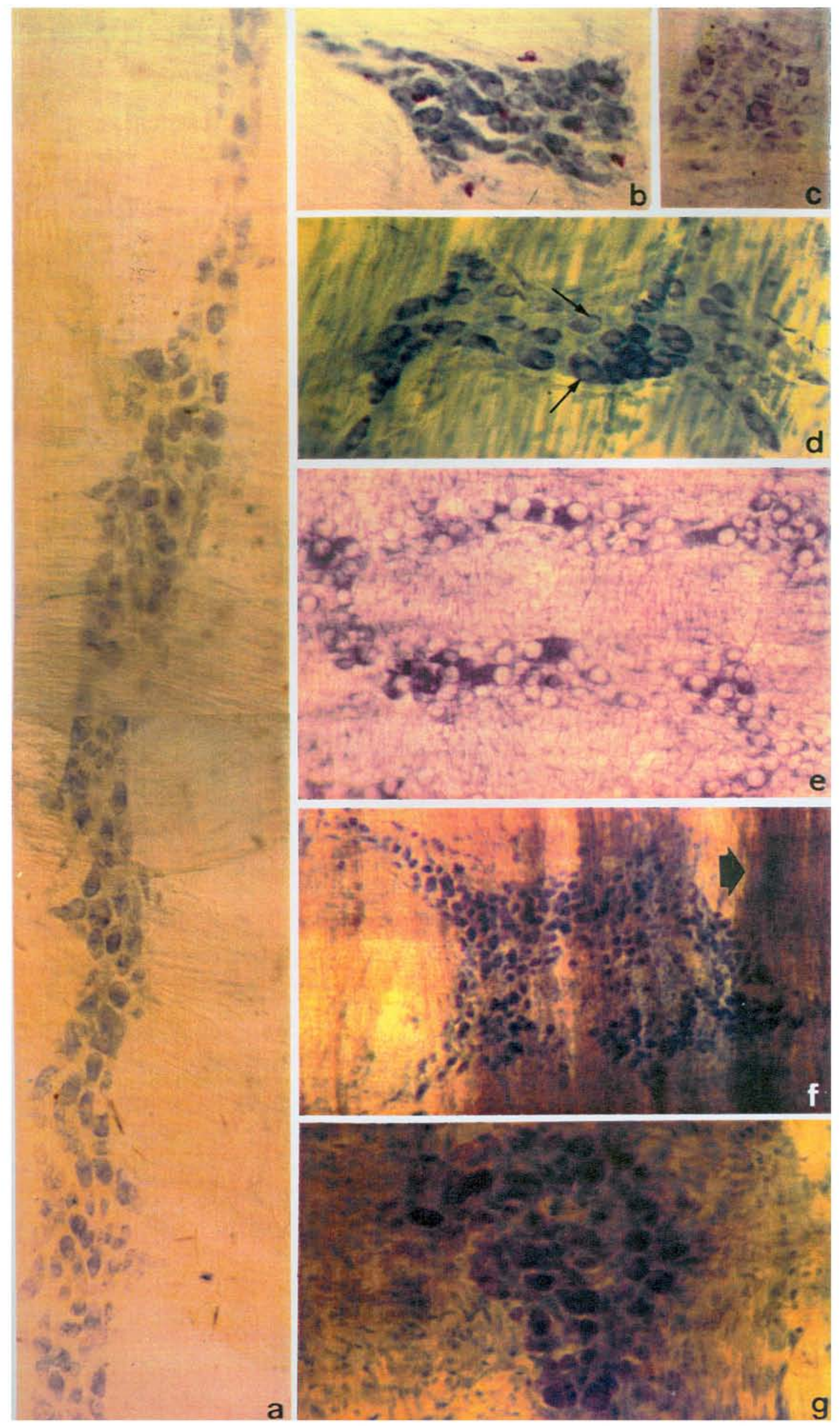




\section{FIGURA 3 - Características gerais do Plexo Mientérico}

a- Neurônios de forma predominantemente alongada e ovalada (setas) presentes em gânglio do intestino delgado da cobaia (Giemsa. 570 X); b- Parte de um gânglio do colo sigmóide de Calomys callosus, evidenciando diferentes formas de neurônios com tamanhos variados e bastante compactados (Giemsa. 1.000 X); c- Gânglios pequenos e esparsos presentes no esôfago do Calomys callosus (Cabeças de seta) (Giemsa. 370 X); d- Plexo do intestino delgado humano. Notar o citoplasma (c), o núcleo bem delimitado (n) com nucléolo evidente (seta). São observadas ainda núcleos de células satélites (s) pouco corados (Giemsa. 980 X); e- Neurônios do esôfago humano em meio a uma grande quantidade de nícleos de células satélites (setas) (Giemsa. $980 \mathrm{X}$ ); f- Neurônios de diversas formas e tamanhos pequeno (1), médio (2) e grande (3) presentes no colo humano (Giemsa. $980 \mathrm{X}$ ); g, h- Gânglio de forma circular ou poligonal e alongada do colo da cobaia. Verificar a grande quantidade de neurônios bastante compactados. (NADH. g- $200 \mathrm{X}$; h- $200 \mathrm{X}$ ). 


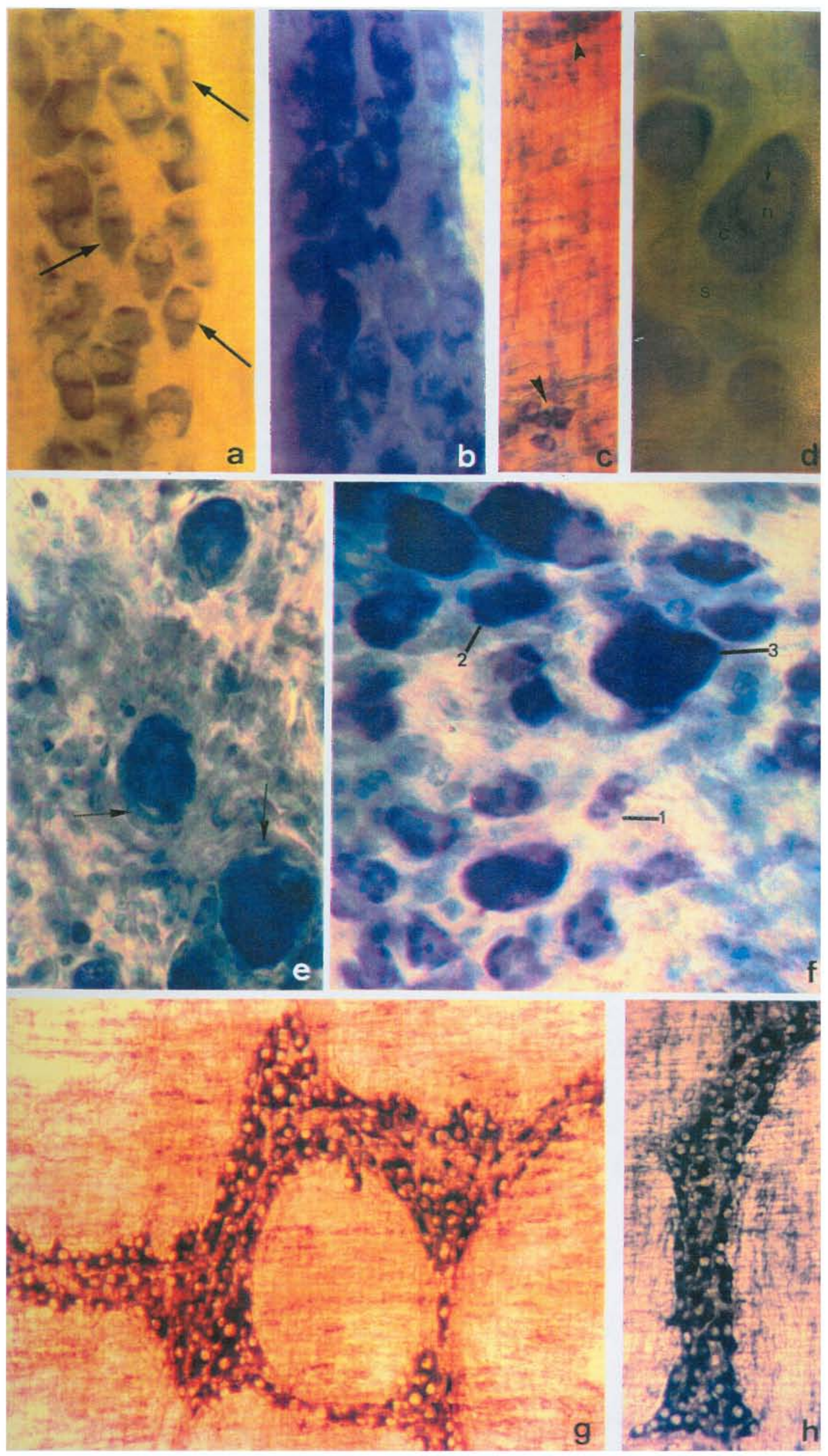




\section{Efeitos do envelhecimento}

Com o envelhecimento, neurônios em degeneração são encontrados nos gânglios mientéricos de animais idosos, ocorrendo uma substancial redução do número de células, acompanhada por mudanças estruturais e reorganização dos neurônios remanescentes (BAKER \& SANTER, 1988; SANTER \& BAKER, 1988; GABELLA, 1989; MECIANO FILHO et al., 1995).

No intestino delgado humano, verificamos que a densidade neuronal do plexo mientérico em indivíduos idosos (com idade média de 71 anos) é 34\% menor do que a do intestino delgado de individuos jovens (com idade média de 32 anos). Esse número aumenta para $38 \%$ quando comparamos especificamente o duodeno (TRAB. V).

Estimamos a mesma porcentagem de redução no número de neurônios para todas as regiões do colo humano (TRAB. I), onde existem gânglios com poucos neurônios esparsamente distribuídos, sendo encontrada grande quantidade de células satélites (Fig. 4a, b). No colo da cobaia, calculamos uma perda neuronal nos animais idosos em torno de 50\% (TRAB. VII), onde pudemos observar, principalmente devido à metodologia utilizada, alterações morfológicas drásticas no contorno dos neurônios ganglionares (Figs. $4 \mathrm{c}, \mathrm{d}$ ).

Mesmo com o contorno alterado, a área do perfil celular não parece modificar-se com a idade, isto é, no colo humano, notamos que tanto o grupo jovem como o grupo idoso, apresentam maior concentração de área na faixa entre 101 e $200 \mu \mathrm{m}^{2}$, e no colo da cobaia, essa faixa para ambos os grupos encontra-se bem distribuida entre os intervalos de 101 e $200 \mu \mathrm{m}^{2}$ e de 201 e $300 \mu \mathrm{m}^{2}$. Portanto, embora ocorra uma diminuição do número de neurônios com a idade, o que se verifica é que não há uma diminuição de um determinado grupo de neurônios de acordo com a área, e sim de todos os grupos neuronais.

Quanto ao tecido conjuntivo associado ao plexo, em indivíduos idosos há um considerável aumento na densidade das fibras colágenas e elásticas, tanto na cápsula quanto no interior do gânglio (Figs. 5a, c, d, f), semelhante ao que ocorre no esôfago (Figs. 5b, e). Não encontramos uma cápsula desenvolvida no colo da cobaia de animais jovens, nem tampouco observamos aumento na densidade de fibras no plexo de cobaias idosas (TRABs. I, VII). 


\section{FIGURA 4 - Envelhecimento do Plexo Mientérico}

a- Preparado total de colo descendente humano (65 anos). Notar a distribuição esparsa dos neurônios se comparada com a figura $2 \mathrm{f}$ (Giemsa. $425 \mathrm{X}$ ); b- Colo transverso humano (68 anos), onde se verifica a grande quantidade de núcleos das células satélites pouco corados (seta) preenchendo os amplos espaços entre os neurônios (Giemsa. 715 X); c- Colo de cobaia (3 anos), evidenciando um gânglio com uma densidade neuronal relativamente elevada, porém com o contorno celular bastante alterado na maioria delas (NADH. $425 \mathrm{X}$ ); d- Gânglio do colo de cobaia (3 anos) com densidade neuronal baixa, e neurônios de contomo alterado (setas). Verificar alguns processos neuronais corados, bem como o contorno dos núcleos das células satélites (cabeças de seta) (NADH. $425 \mathrm{X}$ ). 


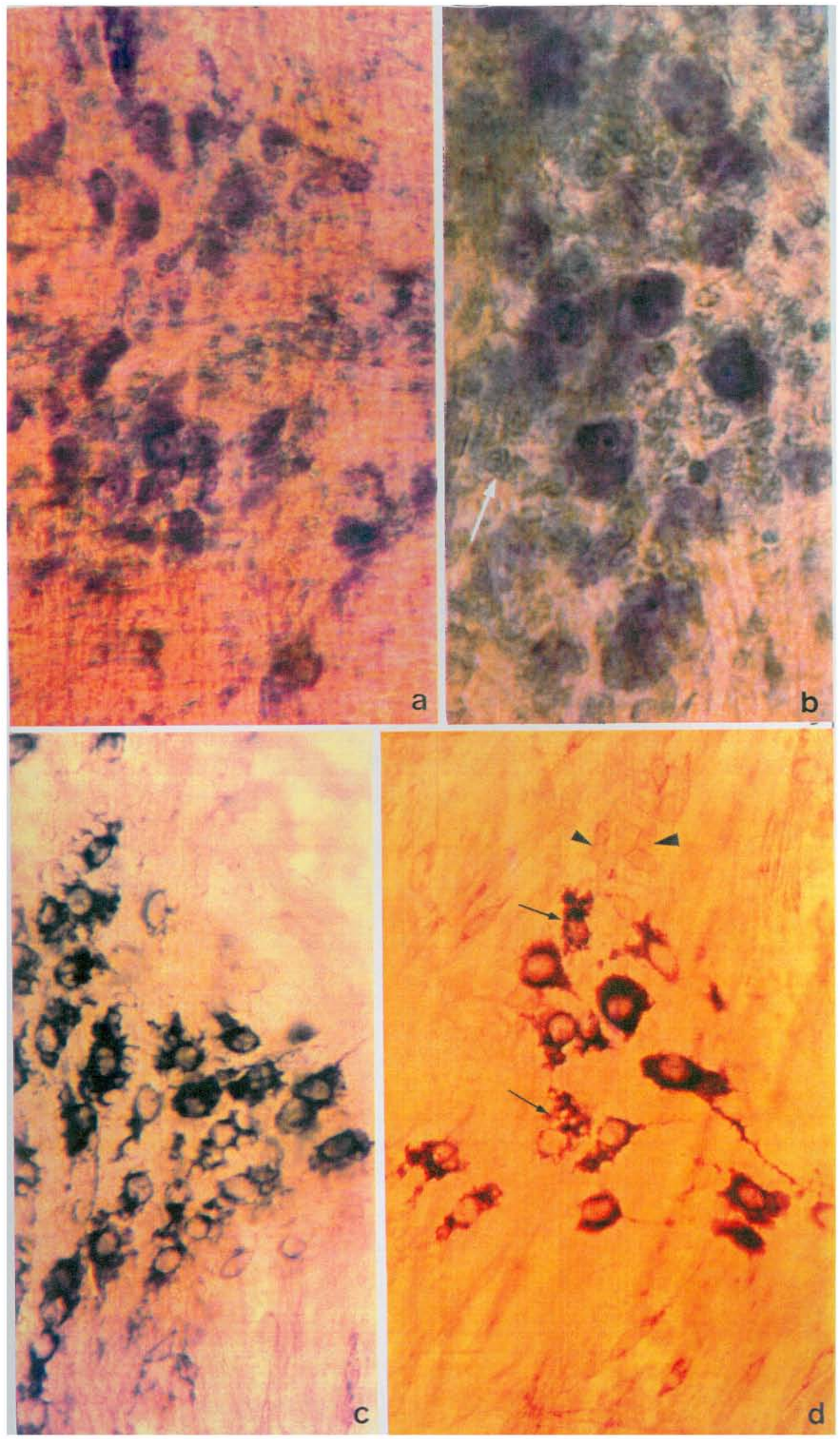




\section{FIGURA 5 - Envelhecimento do Plexo Mientérico}

a- Corte transversal do colo humano evidenciando um gânglio envolto por uma espessa cápsula de tecido conjuntivo (seta). Notar a continuidade da cápsula com o envoltório conjuntivo da musculatura adjacente (M) (Azo-carmin. 275 X); b- Corte transversal de esôfago humano onde se verifica a maior densidade de tecido conjuntivo tanto na cápsula como no interior do gânglio (setas) envolvendo os neurônios $(\mathrm{N})$. Comparar com a figura 1a (Masson. 280 X); c- Cápsula ganglionar bastante espessa (seta) verificada no colo humano. Fibras se projetam no interior do gânglio envolvendo os neurônios (N) (Azo-carmin. 1.100 X); d- Fotomicrografia eletrônica de gânglio do colo humano evidenciando um neurônio $(\mathrm{N})$ envolto por grande quantidade de fibras colágenas (F). Comparar com as figuras $1 \mathrm{~g}, \mathrm{~h}(15.000 \mathrm{X})$;

e- Corte de esôfago humano onde se nota a grande densidade de fibras do sistema elástico tanto na cápsula quanto no interior do gânglio (setas) (Resorcina-fucsina com oxona, $280 \mathrm{X}$ ); f- Maior densidade de fibras do sistema elástico no interior de gânglio do colo humano. Comparar com a figura 1f(Verhoff. 425X). 


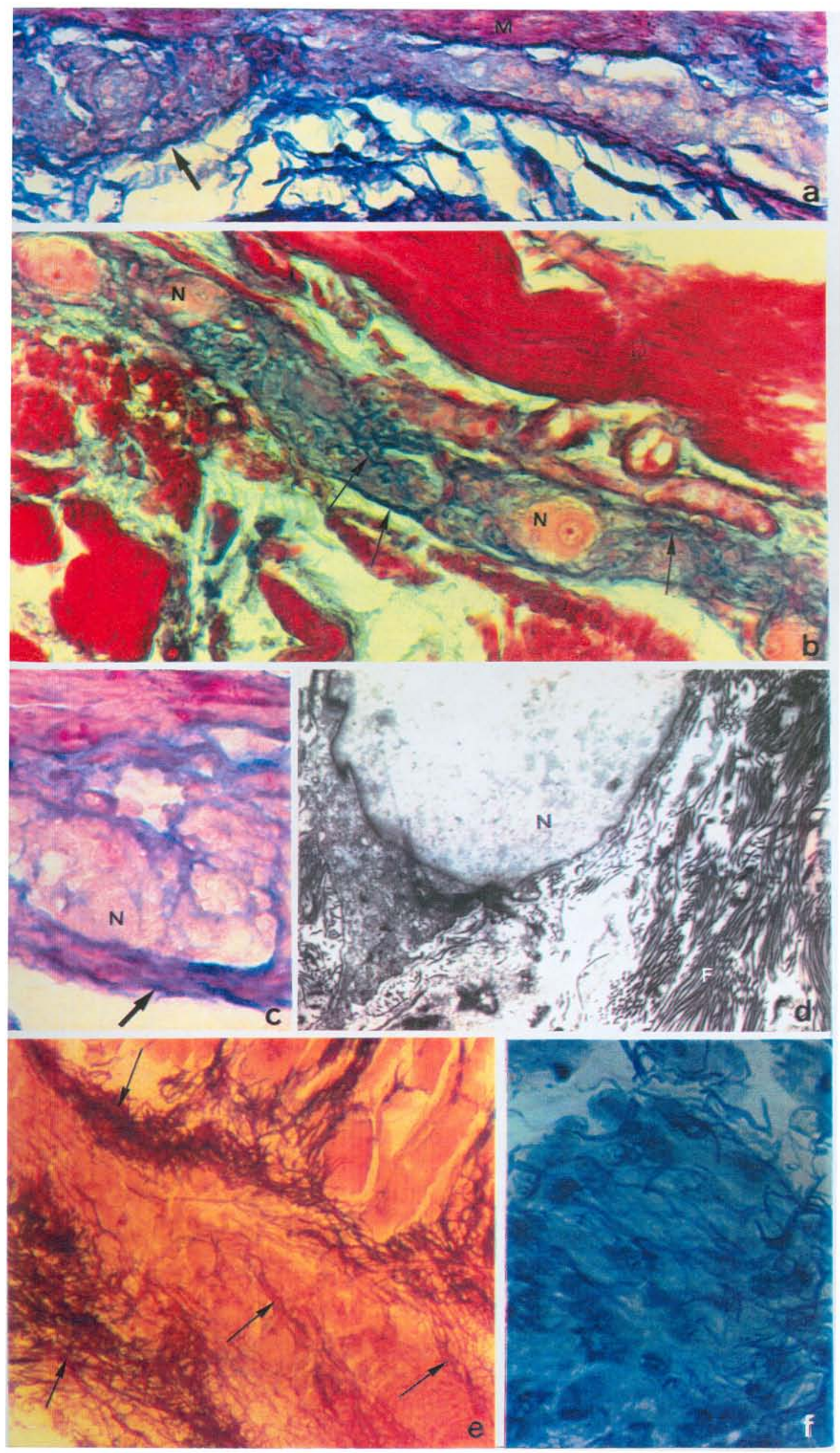




\section{Efeitos da doença de Chagas}

Além da destruição dos gânglios cardíacos, a doença de Chagas também reduz o número de neurônios do plexo mientérico, particularmente os do colo, determinando diversas alterações funcionais decorrentes desse processo (ZANOTTO \& OKUMURA, 1967, FALANGOLA et al., 1990).

Os animais mais utilizados em pesquisas sobre os efeitos da doença são a cobaia, o rato e o camundongo. Em nossos estudos, elegemos o Calomys callosus, por ser um roedor naturalmente infectado pelo $T$. cruzi, e que apresenta uma alta resistência à doença.

Pela análise dos preparados totais de membrana do colo de Calomys callosus obtidos 40 dias após a inoculação com T. cruzi (TRAB. IX), verificamos que os gânglios mientéricos apresentam neurônios mais esparsamente distribuídos, sendo comum a presença de neurônios com contorno alterado (Figs. 6a-d).

Ao compararmos com observações feitas no plexo de animais normais, notamos que os animais não infectados apresentam maior densidade neuronal, sendo também maior a média do corpo celular. Tal fato demonstra claramente que a infecção pelo $T$. cruzi determina no plexo mientérico do colo, uma diminuição na densidade neuronal, e também da área média dos neurônios ganglionares. Esse dado quanto à dimensão dos neurônios, é diferente do observado sobre os efeitos do envelhecimento no plexo mientérico, onde constatamos, além da elevada perda neuronal, uma diminuição de todos os tipos de neurônios do colo quanto ao tamanho, tanto no homem como na cobaia. No caso da moléstia de Chagas, essa diminuição da área média dos neurônios sugere que apenas uma determinada população neuronal é afetada pela doença. 


\section{Efeitos da desnutrição}

No tecido nervoso, os efeitos da desnutrição são descritos principalmente no Sistema Nervoso Central, onde a redução no peso do encéfalo observada pelos diversos autores em várias espécies animais (CHASE et al., 1971; CRAGG, 1972; DEO et al., 1978; ZEMAN, 1967) pode ser determinada por alterações encontradas em seus diversos componentes. Essa redução, tanto em animais desnutridos durante a gestação como em recém-nascidos humanos com retardo do crescimento fetal, é porém menos acentuada do que a verificada em outros órgãos. Em períodos críticos do desenvolvimento, considerados vulneráveis a ações de diversas origens, a desnutrição pode determinar uma perda de terminações nervosas de axônios no córtex (EAYRS \& HORN, 1955); reduzir o número de neurônios multipolares no córtex cerebral e na medula espinal (SHRADER \& ZEMAN, 1973), retardar o processo de mielinização (BASS et al., 1970; DAVISON \& DOBBING, 1966); atrasar a neurogênese cerebelar (WALLINGFORD et al., 1980; LEPRI et al., 1994) diminuindo o número de células granulares e das células de Purkynje (SHRADER \& ZEMAN, 1969) e reduzir a espessura do córtex cerebral (ZAMENHOF et al., 1971; CLARK et al., 1973; YAMANO et al., 1980). A redução do número de células da camada subcortical cerebral e a a diminuição na proliferação celular da camada mais profunda do córtex cerebral também são observadas em consequência de modificações na duração do ciclo de formação de células, que se torna mais prolongado (SHIMADA et al., 1977).

Em relação ao Sistema Nervoso Autônomo, é bastante escassa a literatura que trata dos efeitos da desnutrição, principalmente no que se refere aos plexos entéricos.

A densidade da inervação simpática mais esparsa e irregularmente arranjada e a redução de $27 \%$ no número de neurônios do plexo mientérico foi 
determinada por SANTER \& CONBOY (1990) no jejuno de ratos adultos cujas mães sofreram restrição na dieta durante as duas últimas semanas de gestação, sugerindo que os efeitos da desnutrição materna sobre o Sistema Nervoso Autônomo perduram nos descendentes. Estudos bioquímicos no gânglio cervical superior de ratos submetidos a uma dieta sem proteinas durante trinta dias, demonstraram um decréscimo significativo no conteúdo protéico dos gânglios, principalmente nas enzimas sintetizadoras dos neuro-transmissores (GAETANI et al., 1977). Foi provado em ratos, que um período de desnutrição materna durante a gestação causa redução do tamanho do neurônio e na quantidade de noradrenalina do gânglio mesentérico superior dos filhotes, que persiste durante a fase adulta (CONBOY et al., 1987).

Em nossos estudos com ratos (TRAB. IV), verificamos nos preparados totais de membrana do intestino delgado, que o plexo mientérico de animais mantidos com uma dieta normal, apresenta-se mais densamente povoado que o dos animais desnutridos (Figs. 2e, 6e). Muitos dos neurônios do plexo dos animais nutridos apresentam-se intensamente corados, sugerindo um estágio de maturação avançado; além desses, neurônios com citoplasma reduzido e pouco corado estão presentes, muito provavelmente caracterizando células imaturas (Figs. 6f, g). Ao se comparar essas observações com os animais submetidos a uma dieta com restrição protéica, chama a atenção inicialmente o tamanho reduzido dos neurônios, além da sua conformação alterada. Apesar da existência de neurônios que apresentam uma coloração do citoplasma relativamente intensa, o que predomina nos animais desnutridos, é a presença de células bastante imaturas, pois seu citoplasma além de pouco corado, é também reduzido (Fig. 6h). As áreas dos neurônios do plexo dos animais nutridos são efetivamente maiores que as do plexo dos animais desnutridos. 


\section{FIGURA 6- Efeitos do mal de Chagas e da Desnutrição no Plexo Mientérico}

a- Aspecto geral do plexo mientérico do colo de Calomys callosus infectado pelo $T$. cruzi, onde se observam gânglios apresentando baixa densidade neuronal (comparar com a figura 3h) (NADH. 190 X); b, c- Em maior aumento, nota-se a presença de neurônios alterados (setas) (NADH. 715 X); d- Neurônios com contorno normal e citoplasma bem corado são evidenciados (setas) entremeados a neurônios degenerados (NADH. 425 X); e- Aspecto geral dos gânglios do intestino delgado de ratos desnutridos. Notar a distribuição esparsa dos neurônios (NADH. 280 X); f- Gânglio do intestino delgado de ratos nutridos, com elevada densidade neuronal, onde pode-se observar que, além de neurônios com citoplasma bem evidenciado (seta), alguns neurônios imaturos apresentam o núcleo evidente, porém com o citoplasma pouco corado (cabeça de seta) (NADH. 280 X); g- Neurônios de gânglio do intestino delgado de ratos nutridos com contornos normais (NADH. $1100 \mathrm{X}$ ); hNeurônios de gânglio do intestino delgado de ratos submetidos à desnutrição, onde se verifica nitidamente o tamanho menor dos mesmos, bem como o aspecto alterado de seus contornos (NADH. $1100 \mathrm{X}$ ). 


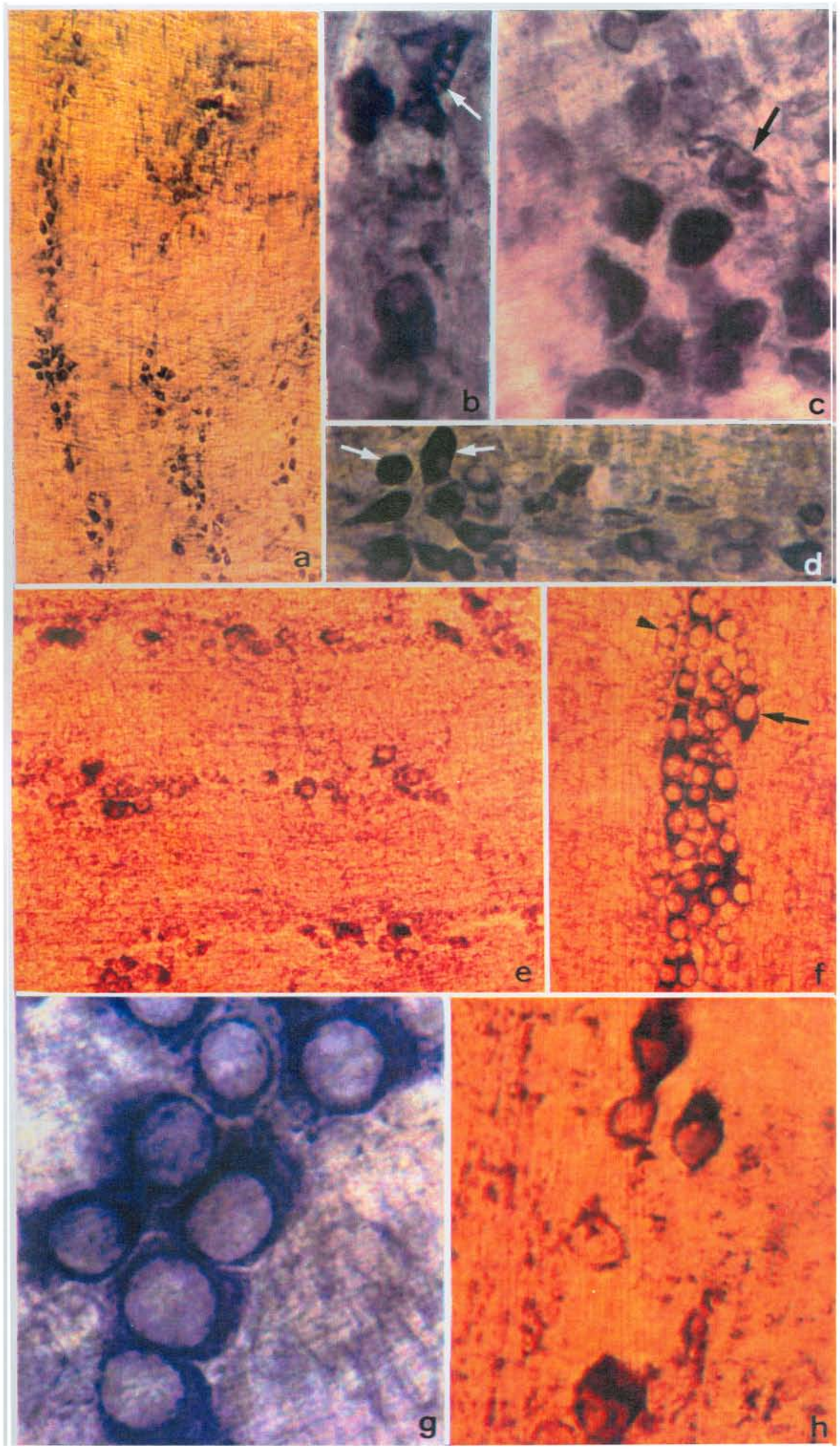




\section{4) PLexo SUBMucoso}

Os gânglios do plexo submucoso frequentemente formam dois grupos, um situado próximo à musculatura $\mathrm{e} o$ outro relacionado à camada mucosa. Vários autores tentaram distinguir entre esses dois plexos que se interconectam, originando muita confusão a partir de definições e nomenclaturas aplicadas às duas partes. SCHABADASCH (1930) refere-se a eles como plexo submucoso interno (de Henle), adjacente à musculatura, e plexo submucoso interno (de Meissner), internamente à mucosa. Após a revisão feita por WILSON et al. (1981a, b), tendo em vista as profusas interconexões entre os gânglios situados em diferentes niveis do tecido conjuntivo da submucosa $\mathrm{e}$ a ausência de qualquer distinção funcional ou histológica entre ambos, os mesmos foram considerados por FURNESS \& COSTA (1987) como plexo submucoso, que deveria ser considerado como plexo de Meissner.

Estudos histofisiológicos sobre o plexo submucoso demonstram o seu envolvimento no controle da atividade contrátil da musculatura lisa no interior das vilosidades, na coordenação da motilidade intestinal e no controle de eletrólitos e transporte de íns através da borda epitelial, tendo sido também enfatizada a presença, em seu interior, de elementos integrativos sensitivos e motores (SCHOFIELD, 1968; HIRST et al., 1975; STACH \& SCHEUERMANN, 1985; FURNESS \& COSTA, 1987).

Apesar de aspectos da sua estrutura e ultra-estrutura serem conhecidos em algumas espécies animais (GUNN, 1968; GABELLA, 1979, 1981; WILSON et al., 1981 a, b; MANNL et al., 1984; BALUK \& GABELLA, 1987), estudos em outras espécies como o camundongo (GABELLA, 1987) são raros. Nossas observações concentram-se no Calomys callosus, para que possamos elucidar a neurocitoarquitetura do plexo nessa espécie animal, objetivando pesquisas futuras relacionadas aos efeitos da moléstia de Chagas nesse importante plexo do sistema digestivo. 


\section{Características gerais}

\section{Morfologia dos gânglios e neurônios}

Em geral, o plexo submucoso é mais irregular que o plexo mientérico no arranjo de suas malhas, no número de gânglios e de neurônios, e no tamanho dos neurônios. Os gânglios do plexo submucoso do intestino delgado da cobaia são bem menores que os do plexo mientérico e com formas muito variadas (TRAB. II). Eles se apresentam circulares, alongados e distantes entre sí, diferentemente da sobreposição observada nos gânglios do plexo mientérico. Os neurônios são arredondados ou em forma de pera. Em regiões do tubo digestivo do Calomys callosus, como o duodeno, o jejuno, o íleo, o ceco e o colo proximal (TRAB. X), o plexo apresenta-se constituído por gânglios pequenos e dispersos, com forma alongada, arredondada e triangular (Figs. 7 a, b). Envoltos por uma delgada cápsula de tecido conjuntivo, seus neurônios possuem diversos formatos $\mathrm{e}$ tamanho variado. Células satélites também são encontradas, semelhante ao verificado para o plexo mientérico (Figs. 7c, d, e).

Preparados de membrana tratados por técnicas específicas para se detectar a atividade da AchE no plexo mostram neurônios AchE positivos em todas as regiões, bem como fibras AchE positivas (TRAB. X). Os gânglios estão unidos por feixes interganglionares que constituem uma malha irregular, sendo observadas entre as malhas de fibras principais, delgadas fibras que constituem uma malha secundária não apresentando diferenças quanto à região estudada (Fig. 8a). Observamos feixes de fibras partindo do plexo submucoso, dirigindo-se para um vaso próximo, onde se forma um plexo perivascular (Fig. 7a).

A análise feita com o auxílio da microscopia eletrônica de varredura após digestão com $\mathrm{HCl}$, permite-nos, além de confirmar o aspecto dos gânglios e das malhas do plexo submucoso situado entre a camada muscular e a mucosa, verificar a presença de feixes de fibras partindo do plexo e penetrando na camada circular de fibras musculares (Figs. 8b, c, d) 


\section{Densidade neuronal e área do perfil celular}

A densidade neuronal varia de acordo com a região ao longo do tubo digestivo do Calomys callosus. Verificamos que há uma diminuição progressiva da densidade de neurônios desde o duodeno, onde os valores são maiores, para o íleo, onde se encontram os menores valores. A partir dessa região, as densidades neuronais aumentam muito discretamente em direção ao colo proximal (TRAB. $\mathrm{X})$.

A densidade neuronal do plexo submucoso do intestino delgado da cobaia demonstra que também para esse animal, o duodeno é o que apresenta a maior densidade (TRAB. II). Os gânglios são pequenos tanto nesta espécie como no Calomys callosus, apresentando uma média de 8 a 10 neurônios/gânglio.

Os neurônios do plexo submucoso do intestino delgado da cobaia são em média menores e menos variáveis em tamanho que os do plexo mientérico. As dimensões da área da imagem do corpo celular variam de 51 a $250 \mu \mathrm{m}^{2}$, sendo que a maior densidade é verificada entre 51 e $100 \mu \mathrm{m}^{2}$.

No Calomys callosus, o tamanho mais frequente dos neurônios no duodeno está entre 50 e $200 \mu \mathrm{m}^{2}$, e no ceco entre 200 a $350 \mu \mathrm{m}^{2}$; no colo, a área dos neurônios varia de 150 a $300 \mu \mathrm{m}^{2}$. Os neurônios encontrados no duodeno são menores, porém nessa região a densidade neuronal é mais elevada, demonstrando uma tendência ao aumento dos corpos neuronais do plexo submucoso nos locais onde a densidade neuronal é menor.

Em linhas gerais, pudemos observar em nossos trabalhos que o padrão do plexo submucoso é diferente do verificado para o plexo mientérico, ou seja, enquanto o plexo mientérico caracteriza-se por apresentar gânglios com uma quantidade relativamente grande de neurônios, o plexo submucoso é formado por gânglios com poucos neurônios. Além disso, se para o plexo mientérico do Calomys callosus (TRAB. III) há uma tendência da elevação da densidade neuronal ao longo do tubo digestivo, é nítido para o plexo submucoso uma diminuição dessa densidade (TRAB. X) 


\section{FIGURA 7 - Características gerais do Plexo Submucoso}

a- Preparado total do intestino delgado de Calomys callosus, onde se observa gânglios (G) unidos por feixes de fibras (F) enviando ramos que envolvem um vaso adjacente (V) (Karnowsky \& Roots. 260 X); b- Aspecto triangular de gânglio presente no íleo, com neurônios alongados $(\mathrm{L})$, arredondados $(\mathrm{R})$ e núcleos de células satélites (cabeças de setas) entre os neurônios (Giemsa. 670 X); c- Neurônios de tamanho pequeno $(\mathrm{p})$, médio $(\mathrm{m})$ e grande $(\mathrm{g})$ observados em gânglio do ceco de Calomys callosus, entremeados por células satélites (cabeça de seta) (Giemsa. 670 X); d- Corte transversal do colo de Calomys callosus evidenciando um vaso sanguineo (S) e um gânglio envolto por delgada cápsula de tecido conjuntivo (seta). Neurônios (n) e células satélites (cabeças de seta) são bem evidenciados (Masson. $670 \mathrm{X}$ ); eEletronmicrografia de um gânglio onde se verifica a presença de um neurônio bem caracterizado pela presença de sua membrana citoplasmática (seta) e por seu nücleo (N) delimitado pela membrana nuclear (cabeças de seta). Uma célula satélite (S) aparece com seu núcleo junto ao neurônio, observando-se ainda, prolongamentos de células semelhantes a fibroblastos (F) e fibras colágenas (C) delimitando o gânglio $(7.200 \mathrm{X})$. 

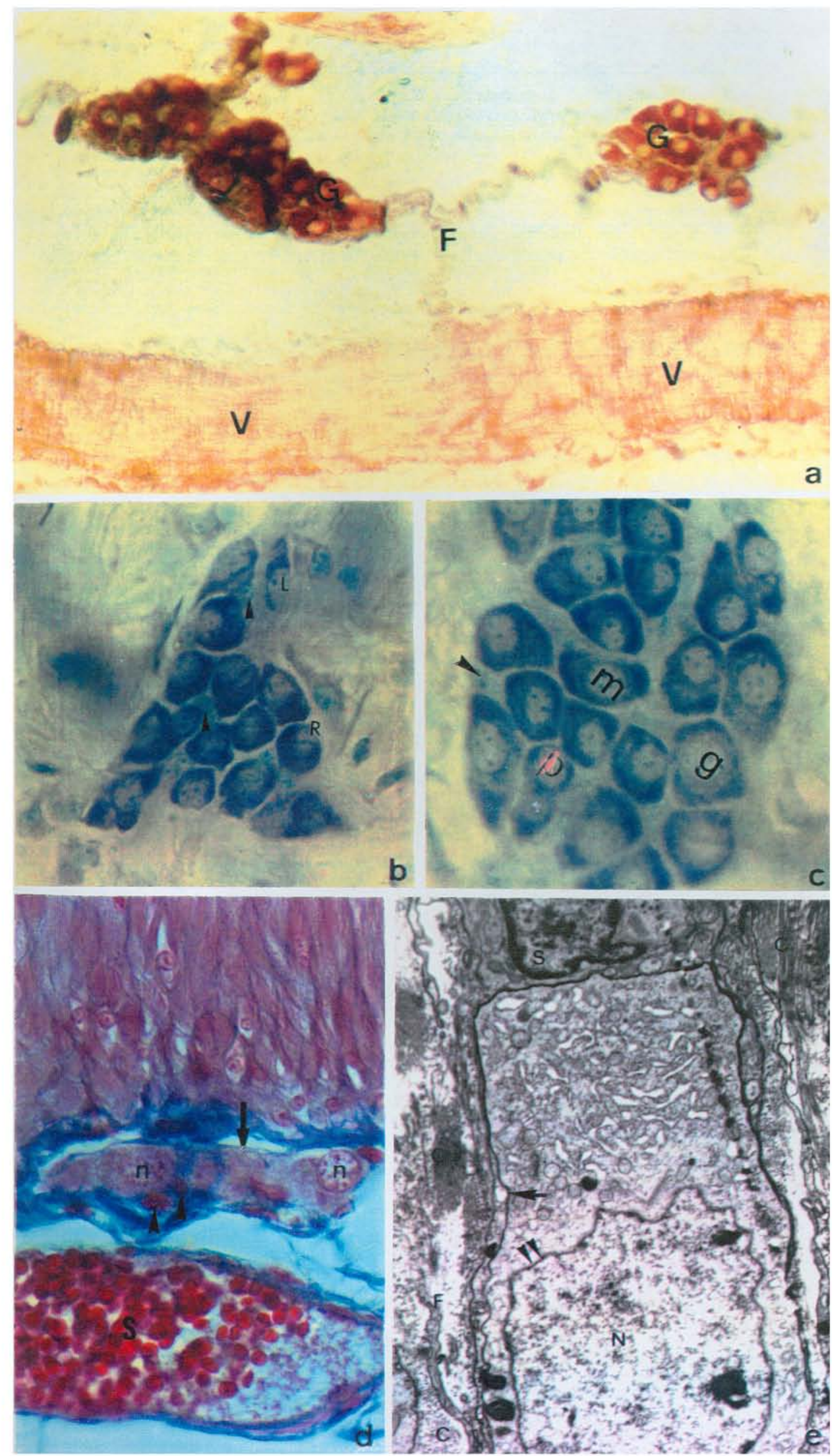


\section{FIGURA 8 - Características gerais do Plexo Submucoso}

a- Morfologia geral do plexo do intestino delgado de Calomys callosus observado em preparados de membrana: gânglios de várias formas $(\mathrm{G})$ interconectados por feixes de fibras nervosas (f) formando malha irregular (Karnowsky \& Roots. $160 \mathrm{X}$ ); b- O mesmo aspecto observado através da microscopia eletrônica de varredura após digestão por Hcl (G- gânglios; C- camada muscular circular; M- mucosa) (450 X); cEm maior aumento, verifica-se a presença de feixes de fibras do plexo (f) penetrando na camada muscular circular (c) (Digestão com Hcl. 940 X); d- Células semelhantes a fibroblastos (setas) junto a um gânglio (G) do intestino grosso de Calomys callosus. F- Feixes interganglionares; C- Camada muscular circular; S- Vaso sanguíneo (Digestão com Hcl. 2.500 X). 

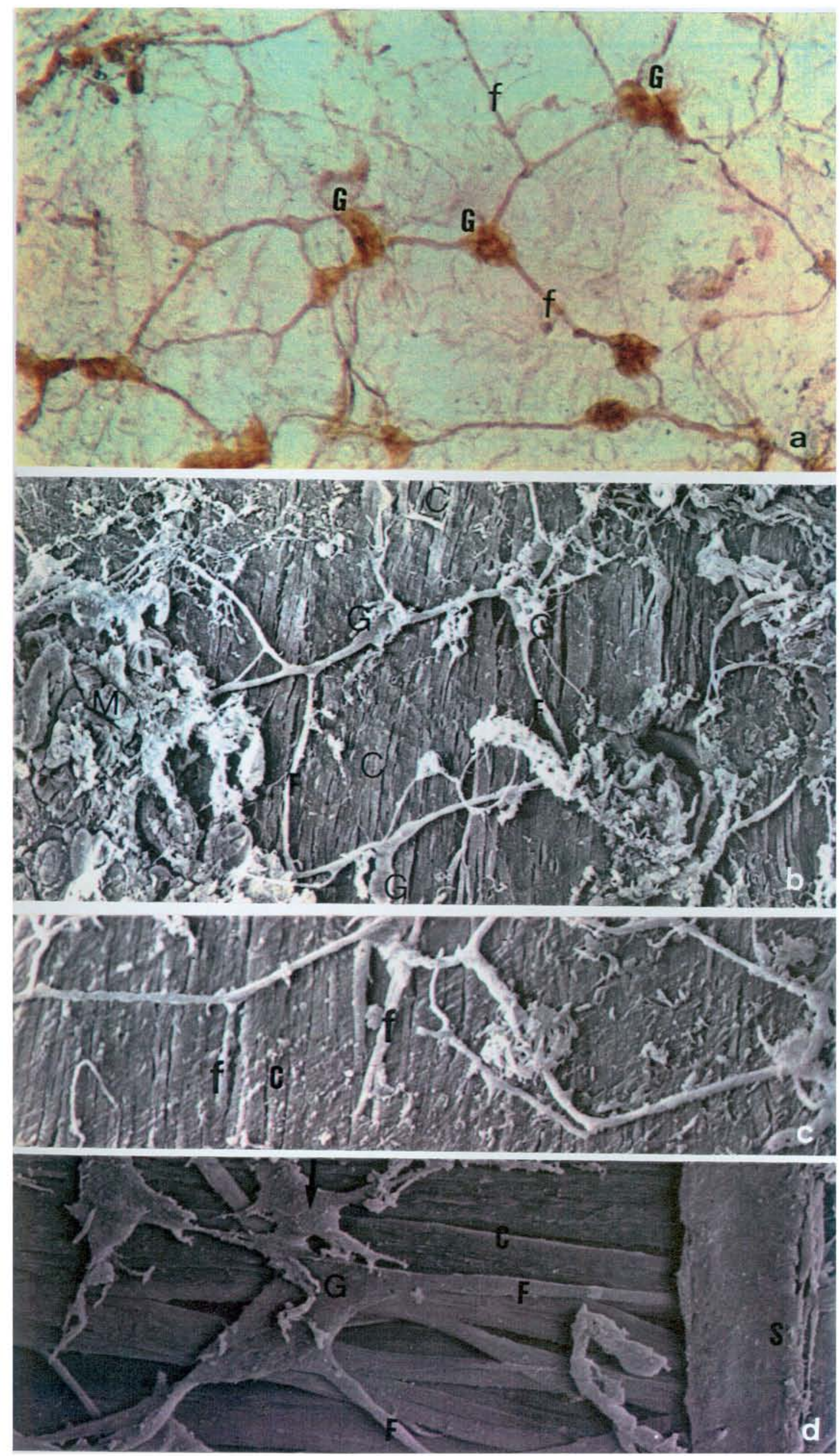


\section{5) PLEXo GANGLiONAR}

A traquéia dos mamíferos recebe fibras provenientes do nervo vago $\mathrm{e}$ da cadeia simpática. Além disso, um grupo de gânglios situado em sua face posterior contribui para essa inervação. Tais gânglios foram considerados por BALUK et al. (1985) semelhantes a outros parassimpáticos, simpáticos e sensoriais, porém menos parecidos com os gânglios entéricos.

Os gânglios recebem fibras do nervos laríngeos e se unem através do plexo ganglionar da traquéia, sendo muito pouco compreendidos se comparados aos gânglios do tubo digestivo. Apesar de um crescente interesse por sua morfologia e função (CAMERON \& COBURN, 1984) este plexo necessita de estudos que melhor determinem sua arquitetura (BAKER et al., 1986), pois ainda são pouco estudados sob o ponto de vista anatômico e fisiológico (CHIANG \& GABELLA, 1986).

O fato de as células musculares da parede da vesícula biliar estarem frouxamente arranjadas e serem muito menores qua as células musculares da muscularis externa, levou alguns autores a compararem sua estrutura à da muscularis mucosae do tubo digestivo, inervada pelo plexo submucoso.

Admite-se que sua inervação ocorre a partir de três plexos distintos sendo o primeiro proveniente da adventícia da artéria ć́stica e seus ramos, o segundo situado na lâmina própria, entre a camada muscular e o epitélio, e o terceiro denominado plexo ganglionar, localizado na face externa da musculatura, adjacente aos feixes musculares ou próximo ao espesso tecido conjuntivo subperitoneal (CAI \& GABELLA, 1983a, b).

Os resultados sobre estudos realizados por diversos autores são contraditórios. GRAPULIN et al. (1968) observaram um rico suprimento de fibras adrenérgicas em diferentes camadas do ducto biliar do cão, inclusive a papila, enquanto TANSY et al. (1974) não confirmaram essa inervação. BAUMGARTEN \& LANGE (1969) demonstraram uma inervação adrenérgica extrínseca à musculatura lisa do ducto cístico no gato e no macaco, mas não a encontraram na cobaia. 


\section{Características gerais}

\section{Morfologia dos gânglios e neurônios}

No Calomys callosus, o plexo ganglionar da traquéia (TRAB. XI) está localizado intimamente relacionado á face posterior do músculo traqueal. Seus gânglios estão envoltos por uma delgada cápsula de fibras colágenas, pouco desenvolvida se comparada à do plexo mientérico humano, de onde se destacam finos septos que envolvem os neurônios em seu interior (Fig. 9a). Da mesma forma, cortes corados com hematoxilina férrica demonstram raras fibras elásticas em torno do gânglio bem como em seu interior.

Os gânglios da traquéia são distribuidos aleatoriamente, sem um padrão específico (Fig. 9b). Empregando-se a técnica da acetilcolinesterase, verificamos a presença de dois troncos nervosos longitudinais, próximos às extremidades dos anéis cartilaginosos (Fig. 9c). Dos troncos longitudinais, partem ramos que se dividem e se anastomosam, constituindo uma rede de malhas irregulares em toda a sua extensão; desta malha, destacam-se delgados feixes que se dirigem lateralmente, penetrando entre os anéis cartilaginosos (Fig. 9d).

Os neurônios estão dispostos preferencialmente em gânglios pequenos e de forma predominantemente arredondada ou ovalada (Figs. 10 a-d). Neurônios de diversas formas são observados entremeados a células satélites, sendo que entre os anéis cartilaginosos, alguns neurônios isolados são encontrados (Fig. 10 e).

O plexo ganglionar da vesícula biliar, como o da traquéia, não é verdadeiramente intramuscular, situando-se sobre a superficie externa da musculatura do órgão. Se esta é derivada da muscularis mucosae, o tecido conjuntivo subperitoneal corresponderia à submucosa intestinal, sendo o plexo ganglionar então equivalente ao plexo submucoso do intestino e não ao plexo mientérico, como geralmente se admite.

$\mathrm{Na}$ vesícula biliar de cobaia (TRAB. II), pudemos observar que os gânglios do plexo ganglionar assemelham-se aos do plexo submucoso, isto é, com poucos neurônios apresentando várias formas, e com núcleo predominantemente excêntrico. 
Densidade neuronal e área do perfil celular

A média do número total de neurônios na traquéia do Calomys callosus é de $279 \pm 51$ neurônios, sendo os gânglios mais frequentes os que apresentam um número entre 6 e 10 neurônios.

A média da densidade neuronal do plexo ganglionar da vesícula biliar é de $6 \mathrm{n} / \mathrm{mm}^{2}$, com uma média de 6 neurônios/gânglio.

A área do perfil celular dos neurônios da traquéia do Calomys callosus mostra que os neurônios mais frequentes medem entre 300 e $400 \mu \mathrm{m}^{2}$, com uma média de $352 \mu \mathrm{m}^{2}$.

Para o plexo ganglionar da vesícula biliar da cobaia, verificamos que a média da área do corpo celular foi de $409 \mu \mathrm{m}^{2}$, sendo que a maioria dos neurônios encontram-se entre 200 e $400 \mu \mathrm{m}^{2}$.

O plexo ganglionar apresenta alguns aspectos distintos em relação aos plexos entéricos, como o tamanho maior de seus neurônios.

Os neurônios da traquéia do Calomys callosus não formam uma população uniforme, apresentando porém uma variação menor que a dos gânglios entéricos, lembrando desta forma, os gânglios da cadeia simpática.

$\mathrm{Na}$ vesícula biliar, embora a densidade neuronal seja menor que a observada para o plexo submucoso, a média do tamanho dos neurônios do plexo ganglionar excede à encontrada para os neurônios do plexo submucoso, compensando aparentemente a menor densidade. Talvez a principal diferença quanto ao aspecto entre o plexo ganglionar da vesícula biliar e o plexo submucoso, esteja na forma dos gânglios, que pequeno em ambos, na vesícula biliar assumem formas bastante irregulares, sendo poucos os gânglios de contorno arredondado ou ovalado (Figs. $10 \mathrm{f}$-h). 


\section{FIGURA 9 - Características gerais do plexo ganglionar}

a- Corte transversal da traquéia de Calomys callosus passando por um gânglio: observamos núcleos de células satélites (setas menores) adjacentes aos neurônios (N) e tecido conjuntivo envolvendo o gânglio, bem como os neurônios individualmente (cabeças de seta). Músculo traqueal (M). (Masson. 230 X); b- Aspecto geral dos gânglios: disposição esparsa e número variado de neurônios em gânglios do plexo da traquéia (setas). Anéis cartilaginosos (*). (Giemsa. $40 \mathrm{X}$ ); c- Plexo da traquéia evidenciando um feixe longitudinal de fibras (seta maior) de onde partem feixes mais delgados (setas menores). Gânglios estão presentes nas junções desses feixes (*) (Karnowsky \& Roots. $100 \mathrm{X}$ ); d- Feixes de fibras do plexo (setas maiores) paralelos aos anéis cartilaginosos $(*)$, inteconectados por feixes delgados (setas menores) (Karnowsky \& Roots. 160 X). 


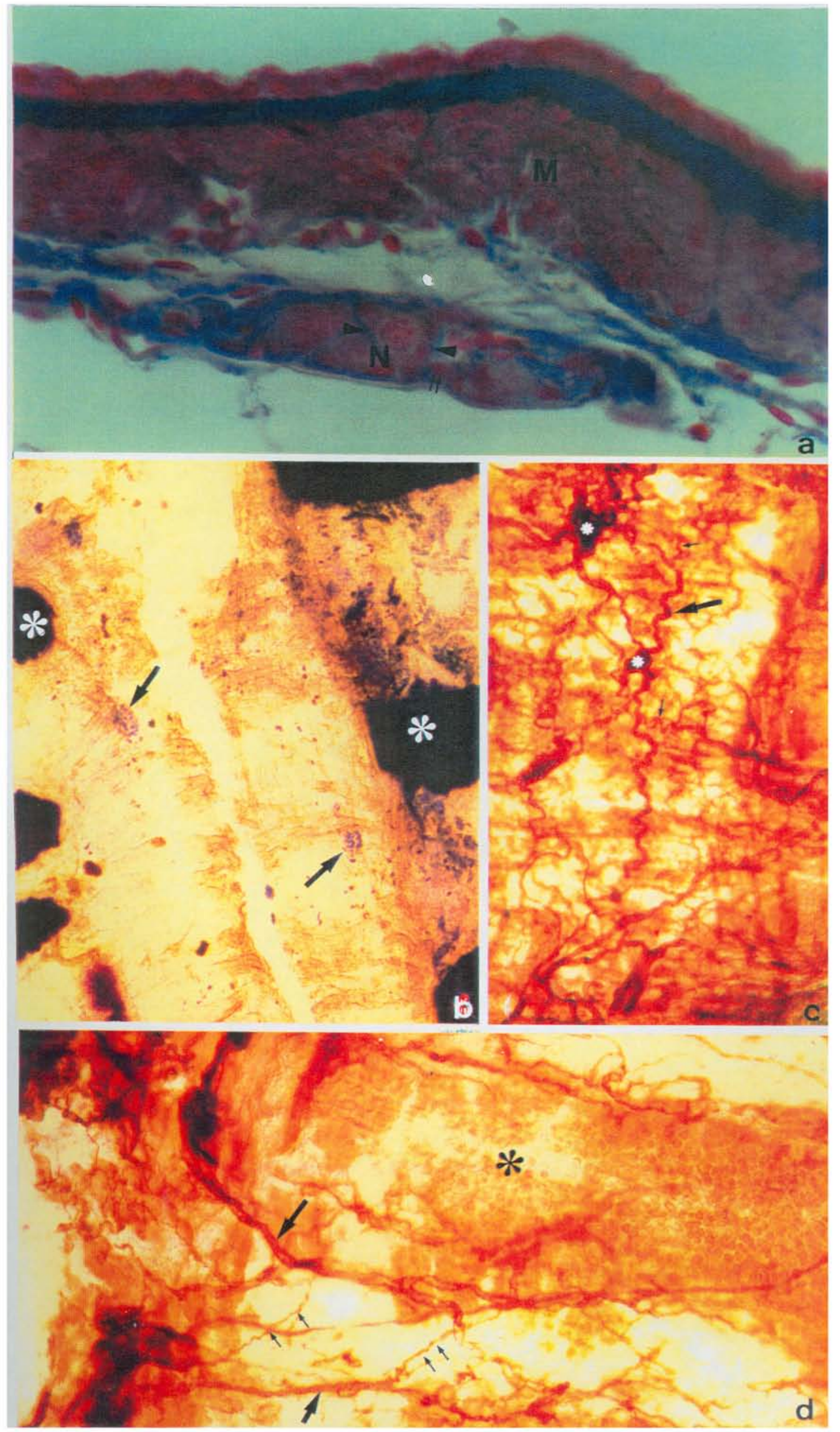




\section{FIGURA 10 - Características gerais do Plexo Ganglionar}

a- Gânglio da traquéia de Calomys callosus de forma arredondada e com elevada densidade neuronal (Giemsa. 260 X); b- Gânglio de forma alongada com neurônios mais esparsamente distribuídos (Giemsa. 260 X); c- Gânglio da traquéia, com reduzido número de neurônios. Músculo traqueal $\left(^{*}\right)$ (Giemsa. $160 \mathrm{X}$ ); d- Gânglio do plexo da traquéia com poucos neurônios de diversos formatos. Observar o feixe de fibras que se destaca do gânglio (setas) (NADH. 425X); e- Neurônio do plexo da traquéia, situado entre os anéis cartilaginosos, circundado por diversas células satélites (setas) (NADH. 670 X); f, g- Gânglios de formas diversas predominates na vesícula biliar de cobaia com neurônios de vários aspectos e tamanhos. Notar o núcleo excêntrico, com um ou dois nucléolos evidentes (Giemsa. 340 X); h- Gânglio da vesícula biliar de cobaia, de forma arredondada, com relativa densidade neuronal e neurônios de contorno arredondado (setas), muito semelhante aos gânglios encontrados no plexo submucoso (comparar com a figura 7c) (Giemsa. $340 \mathrm{X}$ ). 

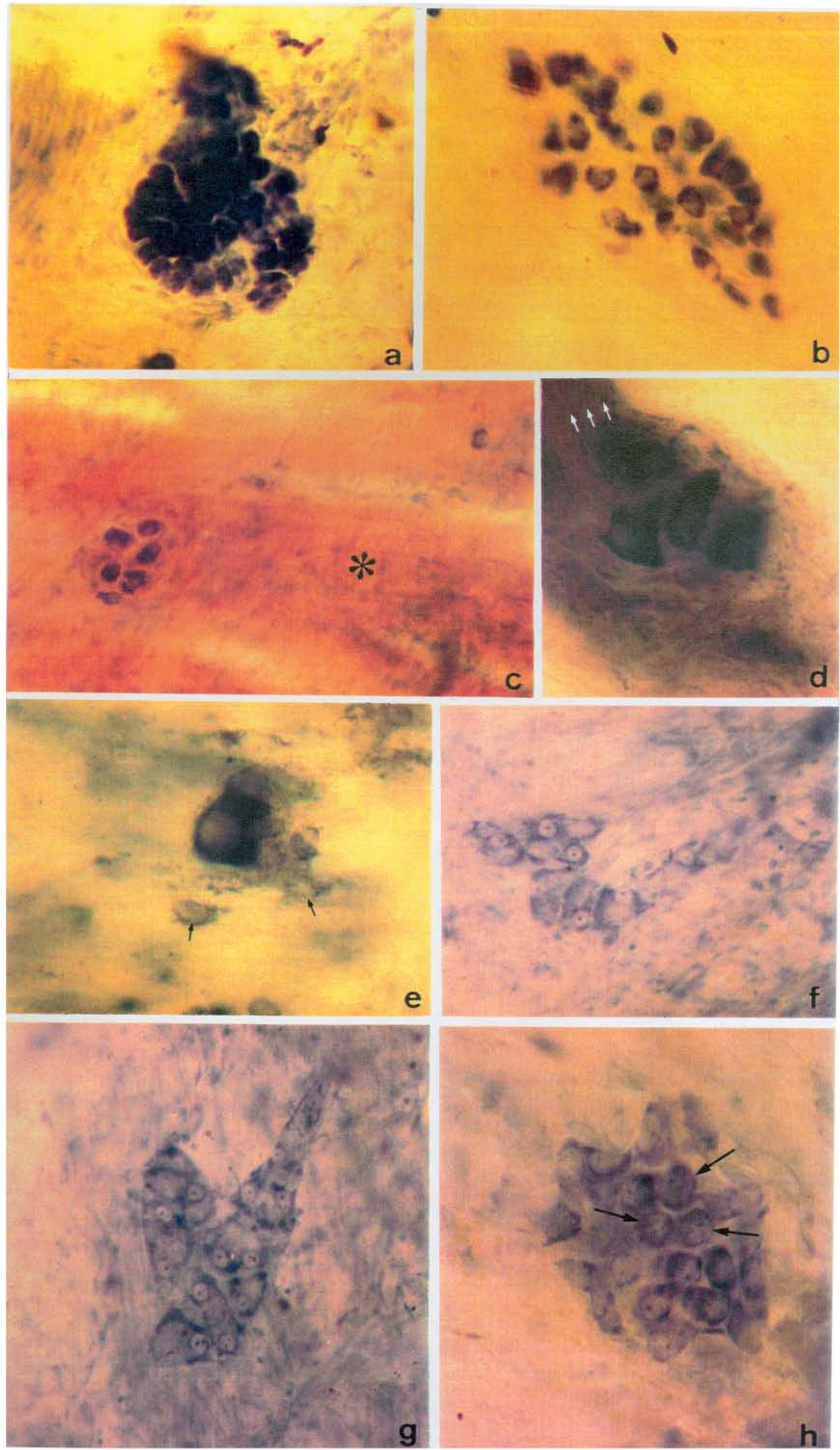


\section{6) PLEXO INTRAMURAL}

Classicamente admite-se que a inervação eferente da bexiga urinária de mamíferos origina-se em neurônios no interior dos gânglios pélvicos (WOZNIAK \& SKOWRONSKA, 1967, DAIL et al., 1975), porém, a presença de células nervosas na parede da bexiga urinária tem sido relatada por diversos autores com o auxílio das mais variadas técnicas (FEHÉR et al., 1979; GILPIN et al., 1983; CROWE et al., 1986; GABELLA, 1990b). Da mesma forma, alguns pesquisadores não têm observado neurônios intramurais na bexiga urinária, permanecendo ainda incerta a dimensão do aparelho neuronal intrínseco da bexiga urinária.

\section{Características gerais}

\section{Morfologia dos gânglios e neurônios}

Os gânglios intramurais da bexiga urinária estão situados em sua camada muscular, semelhante ao que ocorre com os gânglios do plexo mientérico. Independentemente da espécie estudada, muitos neurônios são observados isolados dispersos na parede do órgão, sendo que a maioria entretanto, se encontra agregada, formando gânglios de diversos aspectos e dimensões de acordo com a espécie. A distribuição dos gânglios na parede da bexiga urinária também difere entre as espécies animais. Aliás, essa variabilidade pode ser verificada mesmo quando se compara animais da mesma ordem, como no caso de roedores como o Calomys callosus, o camundongo C57/BLJ e a cobaia (TRAB. XII) ou entre diferentes classes, como a traíra (Osteichthyes), a rã (Amphybia), a tartaruga (Reptilia) e a cobaia (Mammalia) (TRAB. XIII).

$\mathrm{Na}$ bexiga urinária de traíra (Hoplias Spp), encontramos muitos neurônios isolados, sendo que os gânglios presentes no órgão possuem um aspecto rudimentar, com seus nerônios esparsamente agrupados (Figs. 11a, b). No plexo intramural da bexiga urinária de rã (Rana catesbeiana) e de tartaruga (Trachemys dorbignyi), além da presença de neurônios isolados, verificamos gânglios pequenos, porém bem definidos, associados aos espessos feixes de fibras que constituem as malhas do plexo intramural (Figs. $11 \mathrm{c}-\mathrm{h}$ ). Os neurônios e gânglios 
nessas três espécies, são observados espalhados aleatoriamente na parede do órgão. Na cobaia (Cavia porcelus) entretanto, muitos dos gânglios apresentam um número considerável de neurônios e concentram-se ao redor dos óstios ureterais.

Entre animais da mesma ordem, verificamos que no Calomys callosus, os gânglios são pequenos e dispersos; na cobaia variam em forma e tamanho, isto é, como citado anteriormente, observamos desde gânglios pequenos até gânglios com uma quantidade elevada de neurônios (Figs. 11 i, j), agrupados preferencialmente ao redor dos óstios ureterais; no camundongo $\mathrm{C} 57 / \mathrm{BLJ}$, os gânglios são bem desenvolvidos, alguns ultrapassando 200 neurônios, concentrados ao redor do óstio uretral interno (TRAB. XII).

\section{Densidade neuronal e área do perfil celular}

Os aspectos quantitativos são bastante diversos entre as espécies animais. A densidade neuronal observada no plexo intramural da bexiga urinária de roedores é de $756 \mathrm{n} / \mathrm{cm}^{2}$ na cobaia, $2042 \mathrm{n} / \mathrm{cm}^{2}$ no camundongo isogênico C $57 / \mathrm{BLJ}$ e de $58 \mathrm{n} / \mathrm{cm}^{2}$ no Calomys callosus (TRAB. XII). Ao compararmos grupos de animais diferentemente situados na escala zoológica (TRAB. XIII), observamos uma densidade neuronal de $503 \mathrm{n} / \mathrm{cm}^{2}$ na bexiga urinária de peixe, 24 $\mathrm{n} / \mathrm{cm}^{2}$ na bexiga de rã e $12 \mathrm{n} / \mathrm{cm}^{2}$ na bexiga de tartaruga, menores que a observada na bexiga urinária de cobaia.

A média da área da imagem do corpo celular dos neurônios do plexo intramural da bexiga de cobaia é de $253 \mu \mathrm{m}^{2} ; 321 \mu \mathrm{m}^{2}$ para os neurônios da bexiga do camundongo $\mathrm{C} 57 / \mathrm{BLJ}$ e $148 \mu \mathrm{m}^{2}$ para os neurônios da bexiga de Calomys callosus. No peixe, a média é de $161 \mu \mathrm{m}^{2} ; 485 \mu \mathrm{m}^{2}$ na bexiga de rã e $387 \mu \mathrm{m}^{2}$ na bexiga de tartaruga. 


\section{FIGURA 11- Características gerais do Plexo Intramural}

a, b- Neurônios ganglionares da bexiga de Hoplias Spp., encontrados em gânglios rudimentares onde estão esparsamente distribuídos, ou isolados ou em duplas (setas) (Giemsa. 425 X); c, d- Gânglios da bexiga de Rana catesbeiana com dois ou três neurônios de formato preferencialmente alongado. Núcleos de células satélites estão presentes adjacentes aos neurônios (seta) (Geimsa. 425 X); e- Um gânglio da bexiga de Rana catesbeiana de forma alongada com uma relativa densidade neuronal. Observar os feixes de fibras que partem do gânglio (setas) e se dirigem paralelamente à musculatura da víscera (*) (Giemsa. 170 X); f, g, h- Gânglios da bexiga urinária de Trachemys dorbignyi com reduzido número de neurônios. Verificar o espesso feixe de fibras ao qual estão associados ou mesmo incluídos $\left(^{*}\right)$, bem como o formato variado dos neurônios (setas) (Giemsa. 425 X); i, jGânglios da bexiga urinária de Cavia porcelus com diferentes densidades neuronais, onde se observa que os neurônios, com diversas formas, estão mais compactamente dispostos (Giemsa. $425 \mathrm{X}$ ). 

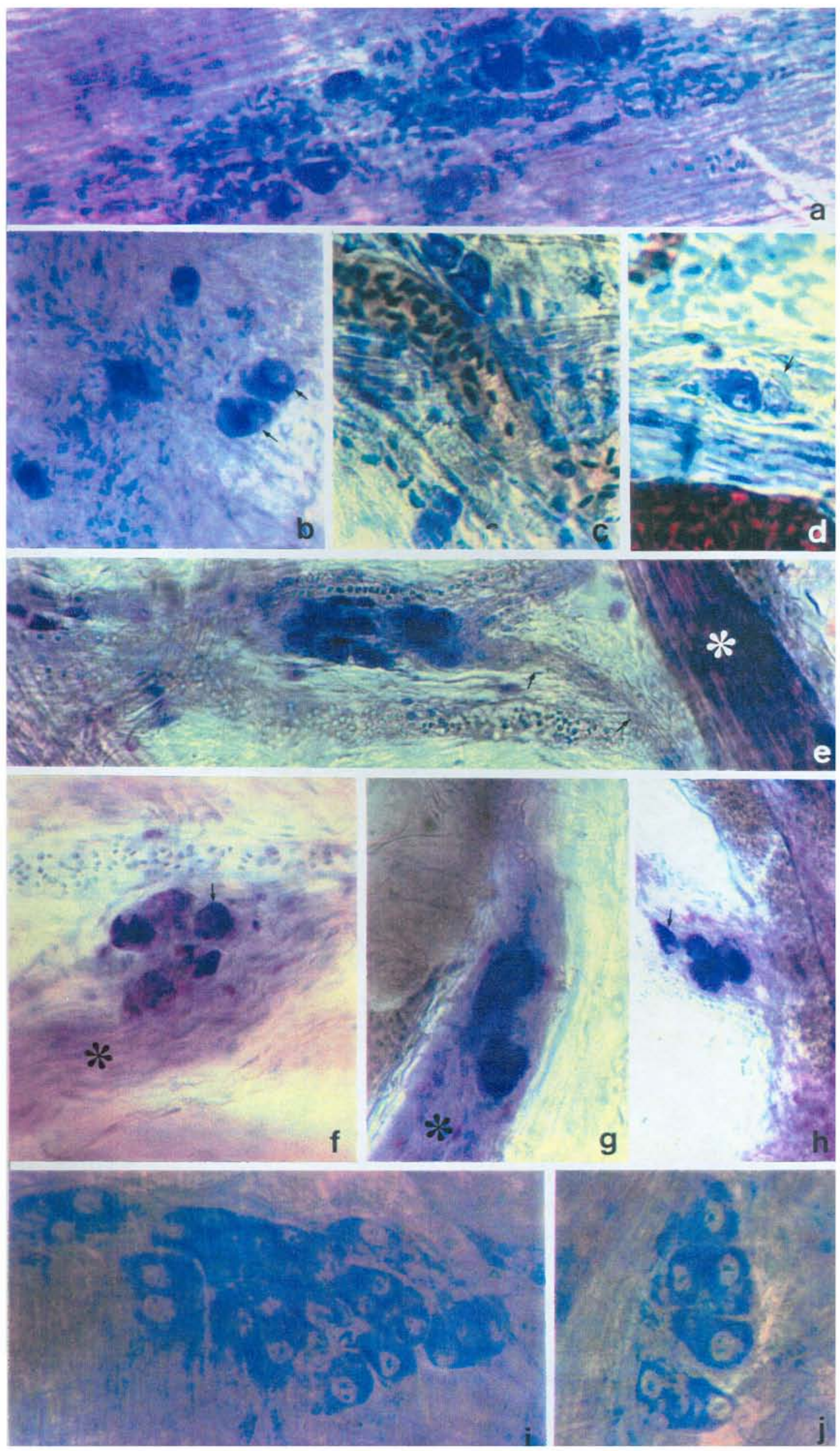


\section{7) COMENTÁRIOS}

Apesar da existência de muitos trabalhos morfológicos e quantitativos sobre os diferentes plexos viscerais, nossos estudos nessa linha de pesquisa permitiram observar diversos aspectos importantes sobre esses plexos, tanto no seu aspecto normal como as alterações decorrentes da ação de diferentes agentes modificadores, sobretudo no homem e no Calomys callosus. Além disso, a atuação nessa área possibilita o planejamento de futuros trabalhos, principalmente de morfologia comparada, visando elucidar questões sobre a atuação desses plexos nas diferentes vísceras, que até o presente momento ainda não foram relatadas ou estão parcialmente respondidas.

No plexo mientérico, pudemos notar, especificamente no homem, que seus gânglios apresentam uma cápsula de tecido conjuntivo bem desenvolvida, cujos elementos fibrosos colágeno e elástico aumentam com o envelhecimento. Não observamos essas características na cobaia, mesmo no processo de envelhecimento. Verificamos também que ocorre uma padronização quanto ao tamanho e à forma dos gânglios para cada região do tubo digestivo de acordo com a espécie. Tais disposições realmente possibilitam o reconhecimento do tipo de animal estudado, bem como da região do tubo digestivo em questão, como no caso do intestino delgado da cobaia, onde o plexo mientérico do duodeno, apresenta gânglios de forma diversa dos observados no jejuno e no íleo, e no intestino grosso, onde a forma aproximadamente pentagonal ou hexagonal dos gânglios é uma característica marcante.

Nos estudos quantitativos sobre o plexo mientérico, notamos que a densidade neuronal tende a ser mais elevada em espécies de menor porte enquanto que o tamanho dos neurônios aumenta em animais de maior porte. Quanto a variações regionais ao longo do tubo digestivo nas diferentes espécies, observamos uma densidade neuronal mais elevada no duodeno em relação às outras regiões do 
intestino delgado, o que muito provavelmente pode estar relacionado à maior espessura da musculatura de suas paredes que é aproximadamente o dobro da observada no jejuno e no íleo. Essa hipótese é reforçada pelas observações feitas em esfincteres do tubo digestivo, onde há um aumento da densidade neuronal em relação a outras áreas não esfinctéricas (IRWIN, 1931; MATSUO, 1934; GUNN, 1968), e também pelo que notamos em relação à disposição dos neurônios intramurais, que são particularmente abundantes em um raio de $1 \mathrm{~mm}$ aproximadamente ao redor dos óstios ureterais.

Muitas pesquisas demonstram que os plexos, particularmente o plexo mientérico, sofrem alterações quando submetidos a diversos agentes modificadores de sua fisiologia normal. Em nossas pesquisas sobre os efeitos do envelhecimento, é importante destacar que a redução neuronal que observamos talvez não deva ser necessariamente legada a um processo degenerativo do plexo mientérico, pois pode ser que ocorra somente a eliminação de neurônios redundantes (GABELLA, 1989), tendo como resultado a eficiência aumentada dos elementos sobreviventes.

Além disso, a diminuição semelhante do número de neurônios quanto aos seus diversos tamanhos, pode significar que também os diferentes tipos de neurotransmissores entéricos sejam afetados pelo decréscimo do número de neurônios, reduzindo desta forma, o potencial de suas variadas ações sobre as estruturas do tubo digestivo.

Parece-nos que uma das principais questões a ser elucidada quanto ao envelhecimento reside no fato de se tentar estabelecer se essa redução do número de neurônios acontece em uma determinada fase da vida, considerada então um período crítico, ou se tal processo se estabelece gradativamente ao longo do processo de envelhecimento. Estudos que determinem e comparem as densidades neuronais bem como os diversos aspectos ultraestruturais dos neurônios ganglionares em faixas etárias mais estreitas podem efetivamente contribuir para uma resposta a essa questão. 
O mesmo enfoque deve ser dado aos efeitos da desnutrição sobre os componentes do plexo, considerando-se as fases migratórias dos neuroblastos que irão se desenvolver no interior das vísceras. Além disso, ainda que tenham sido constatadas alterações nos plexos devido a esse importante fator modificador, seus efeitos não foram ainda avaliados para que se possa realmente afirmar se essas alterações são realmente irreversíveis como em processos mais agressivos como a moléstia de Chagas, onde a desorganização dos plexos do esôfago e do colo está relacionada a importantes disfunções dessas vísceras. Estudos complementares como os efeitos de uma renutrição são importantes para que possamos determinar até que ponto a desnutrição pode alterar as características morfofuncionais dos gânglios viscerais, e, consequentemente, a atividade visceral como um todo.

Porém, não somente os neurônios devem ser avaliados. As alterações de outros componentes ganglionares devem ser também cuidadosamente estudadas, como os elementos fibrosos e as células satélites, até então relegadas a um segundo plano, e que, somente recentemente, através de pesquisas sobre sua atuação no sistema nervoso central, têm sido consideradas quanto aos seus importantíssimos efeitos neurotróficos. Uma vez que essas células suporte existem em quantidade elevada nos gânglios viscerais, estudos imunohistoquímicos sobre a sua atuação nos plexos constituem um campo importante pois as mesmas definitivamente deixaram de ser órgãos passivos para serem consideradas estruturas atuantes no desempenho do sistema nervoso como um todo.

Em nossos trabalhos tivemos a oportunidade de observar uma grande diversidade quanto ao tamanho neuronal, nos vários plexos viscerais. Assim, por exemplo, notamos que o tamanho dos neurônios do plexo ganglionar da vesícula biliar da cobaia é bem maior quando comparados aos neurônios do plexo submucoso do intestino delgado, e que a variabilidade no tamanho dos neurônios do plexo mientérico é maior que a observada para os neurônios da traquéia. 
Estudos sobre os gânglios espinais e o sistema nervoso central têm demonstrado que o tamanho dos neurônios cujos processos se projetam para a periferia estão de alguma forma relacionados com o tamanho do território de inervação, existindo uma correlação similar nos gânglios da cadeia simpática. Acreditamos ser verdadeira essa afirmação, pois a variablidade neuronal do plexo mientérico é proporcional ao tipo de território a ser inervado, evidentemente mais complexo se comparado ao da traquéia. Essas observações permitem inferir ainda que, no caso de animais infectados pelo $T$. cruzi, a redução da densidade neuronal do plexo mientérico do colo e principalmente, a diminuição da média do tamanho do neurônio deva estar diretamente relacionada à destruição dos diferentes órgãos alvo.

Uma análise comparativa entre os plexos mientérico e submucoso da mesma região do intestino delgado demonstra valores inversamente proporcionais quando analisamos a densidade neuronal ao longo do órgão, ou seja, enquanto a densidade neuronal diminui no plexo mientérico, ela aumenta no plexo submucoso. Fato interesseante de se registrar é que, embora a densidade seja elevada no plexo mientérico, ocorre uma proporção constante de 2,5 a 4 neurônios do plexo mientérico para cada neurônio do plexo submucoso. Como se estabelece essa proporcionalidade, é ainda uma questão a ser respondida. Além disso, verificamos ainda que, embora em espécies diferentes, a média do tamanho do corpo do neurônio é maior nos nos neurônios do plexo submucoso do colo do que a dos neurônios do plexo mientérico da mesma região.

Quando observamos o comportamento do plexo intramural comparando-se grupos representativos de animais de espécies diferentes na escala zoológica, verificamos que, diferentemente do que acontece com a cobaia por exemplo, cuja tendência desses gânglios é se concentrarem ao redor dos óstios uretrais, os gânglios e neurônios estão dispersos nas paredes da bexiga urinária. Apesar de existirem gânglios em todas as espécies estudadas, a tendência evolutiva 
é a de que os neurônios se agrupem em gânglios, talvez devido ao aumento considerável da musculatura da bexiga, que por sua vez provavelmente deve estar relacionado ao meio ambiente em que vive o animal. Assim, como pudemos observar na traira, na rã e na tartaruga, a musculatura da bexiga urinária está frouxamente arranjada quando comparada com a da cobaia, ou mesmo com a do camundongo C57/BLJ.

Questão que também deve ser elucidada, é o fato de animais como o rato e o camundongo não apresentarem neurônios intramurais e o o camundongo C57/BLJ possuir uma grande quantidade de neurônios agrupados em densos gânglios ao redor de uma região fisiologicamente importante do órgão, ou seja, o óstio uretral interno. Observações como estas levam a crer que o meio ambiente desempenha um papel fundamental no desenvolvimento e funcionamento das diferentes vísceras, e consequentemente, na disposição dos plexos viscerais. Este é sem dúvida um vasto campo a ser explorado e que seguramente poderá fornecer subsídios importantes à compreensão da atividade dos plexos viscerais.

Como se pode depreender, a atuação dos gânglios nervosos viscerais ainda está longe de estar completamente estabelecida. Os gânglios apresentam uma ampla diversidade neuronal, sendo que a maioria permanece com função ainda desconhecida. As relações entre essa diversidade influenciando a atuação dos plexos e toda a extensão das relações destes e a função visceral ainda precisa ser elucidada. A interconexão entre os vários neurônios viscerais e a possivel presença de tratos definidos ou vias nesses plexos são também obscuras. A possibilidade de que diferentes gânglios viscerais contenham grupos neuronais que atuem como estruturas individuais como os núcleos encefálicos, não pode também ser excluída.

Nota-se que, em relação ao Sistema Nervoso Central em que muito se conhece sobre as conexões entre os neurônios, pouco se sabe a respeito destas nos plexos viscerais talvez devido em parte à dificuldade de se estabelecerem seus circuitos locais. 
Como indagado por GERSHON \& ERDE (1981): “deverão então esses plexos permanecerem atormentadoramente simples porém enigmáticos?" Isso parece improvável, pois como eles emergiram de um longo período de negligência, a velocidade de novas descobertas tem se tornado impressionantemente rápida, fazendo com que novos fatos sejam descritos continuamente. Um armazenamento dos conhecimentos adquiridos sobre essas estruturas não deverá demorar muito tempo e com ele, deverão surgir novos avanços sobre sua atuação no funcionamento visceral, bem como a elucidação dos fatores que determinam suas desordens funcionais. Além disso, as modernas técnicas imunohistoquímicas permitem vislumbrar a possibilidade de se estudar com maior precisão não somente a estrutura dos neurônios ganglionares, mas também o papel desempenhado por outras células encontradas no interior dos gânglios, como as células satélites, e as células intersticiais de Cajal, admitidas como envolvidas na regulação do ritmo peristáltico (BEREZIN et al., 1990; CHRISTENSEN et al., 1992).

Pelo exposto, verificamos que, embora várias características morfológicas dos plexos viscerais sejam conhecidas em diversas espécies, principalmente em relação ao seu aspecto normal, muitas delas ainda não foram suficientemente exploradas, quer sob o ponto de vista evolutivo, ou, principalmente em relação à ação dos diversos agentes modificadores. Tais agentes, além do envelhecimento, a desnutrição e a moléstia de Chagas, incluem ainda os efeitos do diabetes, tema que recentemente começamos a abordar em nossos estudos.

Desta forma, acreditamos que, com o aprimoramento das diferentes metodologias até aquí empregadas, principalmente a microscopia eletrônica, e a necessária adequação das pesquisas às recentes técnicas imunohistoquímicas, os trabalhos nesta linha sem dúvida contribuirão para elucidar diversos pontos importantes da fisiologia visceral que ainda permanecem obscuros. 


\section{8) TRABALHOS QUE DERAM ORIGEM À TESE}

I- GOMES, O.A.; DE SOUZA, R.R.; LIBERTI, E.A. The effects of aging on the myenteric ganglia of the human colon. Gerontology. (submetido em fevereiro de 1996).

II- LIBERTI, E.A.; QUEIROZ, L.M.; POMPEU, E.; PERITO, M.A.M.; MINARELLI, A.M.; MORAES, J.O.R.; DE SOUZA, R.R. A quantitative and comparative study of the ganglionic neurons in the myenteric and submucous plexuses of the small intestine, and in the intramural plexus of the gall bladder of the guinea-pig. Rev. Bras. Ciên. Morfol., 11(2):106114, 1994.

III- MAIFRINO, L.B.M.; PRATES, J.C.; DE SOUZA, R.R.; LIBERTI, E.A. Myenteric plexus of the Calomys callosus digestive tract. Morphometry and acetylcholinesterase activity. Brazilian J. Med. Biol. Res. (submetido em abril de 1996).

IV- LIBERTI, E.A. Estudo morfoquantitativo do plexo mientérico do intestino delgado de ratos desnutridos. (em andamento).

V- DE-SOUZA, R.R.; MORATELLI, H.B.; BORGES, N.; LIBERTI, E.A. Ageinduced nerve cell loss in the myenteric plexus of the small intestine in man. Gerontology, 39:183-188, 1993.

VI- DE SOUZA, R.R.; FERRAZ DE CARVALHO, C.A.; LIBERTI, E.A.; FUJIMURA, I. A quantitative study on the myenteric plexus of the distal end of the human esophagus. Gegenbaurs morphol. Jb., 134 (4):565-574, 1988.

VII- LIBERTI, E.A.; ALVES, N.; PRATES, J.C.; DE SOUZA, R.R. Myenteric neuron number and sizes and ganglionic connective tissues in aged guinea-pig colon (em fase de conclusão). 
VIII- GASPAR, L.P.; DE SOUZA, R.R.; LIBERTI, E.A. Estudo comparativo dos gânglios do plexo mientérico do esôfago, estômago, intestino delgado e colo humanos. (em andamento).

IX-DE SOUZA, R.R.; VASCONCELOS, D.C.; MAIFRINO, L.B.M.; LIBERTI, E.A. Número de neurônios do coração e do plexo mientérico do colo sigmóide do Calomys callosus na fase crônica da infecção experimental pelo T. cruzi. (em fase de conclusão).

X- BORGES, N.; LIBERTI, E.A.; DE SOUZA, R.R. Qualitative and quantitative aspects of the submucous plexus (Meissner) in the small and large intestine of Calomys callosus. Mem. Inst. Oswaldo Cruz. (em fase de conclusão).

XI- FURLANI, V.C.G.; LIBERTI, E.A.; BORGES, N.; DE SOUZA, R.R. Morphological and quantitative study of ganglionated plexus of the Calomys calosus trachea. (em fase de conclusão).

XII- LIBERTI, E.A.; DE SOUZA, R.R.; PERITO, M.A.M.; ALVES, N.; CHADI, G. Number, size and distribution of ganglion neurons in urinary bladder of rodents. Biol. Res., 27:123-128, 1994.

XIII- LIBERTI, E.A.; NOVAES, R.L.C.; BLAZQUEZ, F.J.H.; MINARELLI, A.M.; INTERLIZANO FILHO, W.; DE SOUZA, R.R. Intramural neurons in the urinary bladder of Hoplias Spp., Rana catesbeiana, Trachemys dorbignyi, and Cavia porcelus. I. Quantitative study of the nerve cells. Ann. Sci. Naturelles. (aceito em 28/02/96). 


\section{9) REFERÊNCIAS BIBLIOGRÁFICAS}

AUERBACH, L. Fernere vorläufige Mitteilung über den Nervenapparat des Darmes. Virchows Arch. Pathol. Anat., 30:457-460, 1864.

BAKER, D.G.; McDONALD, D.M.; BASBAUM, C.B.; MITCHELL, R.A. The architecture of nerves and ganglia of the ferret trachea as revealed by acetylcholinesterase histochemistry. J. Comp. Neurol., 246(4):513-526, 1986.

BAKER, D.M. \& SANTER, R.M. A quantitative study of the effects of age on the noradrenergic innervation of Auerbach's plexus in the rat. Mech. Ageing Dev., 42:147-158, 1988.

BALUK, P.; FUJIWARA, T.; MATSUDA, S. The fine structure of the ganglia of the guinea-pig trachea. Cell Tissue Res., 239(I):51-60, 1985.

BALUK, P. \& GABELLA, G. Fine structure of the autonomic ganglia of the mouse pulmonary vein. J. Neurocytol.., 16:169-184, 1987.

BALUK, P. \& GABELLA, G. Innervation of the guinea-pig trachea: A quantitative morphological study of intrinsic neurons and extrinsic nerves. J. Comp. Neurol., 285:117-132, 1989.

BARBOSA, A.J.A. Técnica histológica para gânglios nervosos intramurais em preparados espessos. Rev. Bras. Pesq. Méd. Biol., 11:95-97, 1978.

BASS, N.H.; NETSKY, M.G.; YOUNG, E. Effect of neonatal malnutrition on developing cerebrum. I. Microchemical and histologic study of cellular differentiation in the rat. Arch. Neurol. (Chic.), 23:289-302, 1970. 
BAUMGARTEN, H.G.; LANGE, W. Extrinsec adrenergic innervation of the extrahepatic biliary system in guinea-pigs, cats and rhesus monkes. Zeit. für Zellforsch. Mikrosk. Anat., 100:606-615, 1969.

BEREZIN, I.; HUIZINGA, J.D.; DANIEL, E.E. Atructural characterization of interstitial cells of Cajal in myenteric plexus and muscle layers of canine colon. Can. J. Physiol. Pharmacol., 68:1419-1431, 1990

BURNS, G.A. \& CUMMINGS, J.F. Equine myenteric plexus with special reference to the pelvic flexure pacemaker. Anat. Rec., 230:417-424, 1991.

CAI, W.Q. \& GABELLA, G. Innervation of the gall bladder and biliary pathways in the guinea-pig. J. Anat., 136:97-109, 1983a.

CAI, W.Q. \& GABELLA, G. The musculature of the gall bladder and biliary pathways in the guinea-pig. J. Anat., 136:237-250, 1983b.

CAI, W.Q. \& GABELLA, G. Structure and innervation of the musculature at the gastroduodenal junction of the guinea-pig. J. Anat., 139:93-104, 1984.

CAMERON, A.R. \& COBURN, R.F. Electrical and anatomical characteristics of the ferret paratracheal ganglion. Am. J. Physiol., 246:C450-458, 1984.

CHASE, H.P.; DABIERE, C.S.; WELCH, N.N.; O'BRIEN, D. Intrauterine undernutrition and brain development. Pediatrics, 47:491-500, 1971.

CHIANG, C.H. \& GABELLA, G. Quantitative study of the ganglion neurons of the mouse trachea. Cell Tissue Res., 246:243-252, 1986. 
CHRISTENSEN, J.; STILES, M.J.; RICK, G.A.; SUTHERLAND, J. Comparative anatomy of the myenteric plexus of the distal colon in eight mammals. Gastroenterology, 86:706-713, 1984.

CHRISTENSEN, J.; RICK, G.A.; LOWE, L.S. Distributions of interstitial cells of Cajal in stomach and colon of cat, dog, ferret, opossum, rat, guinea-pig and rabbit. J. Autonom. Nerv. System, 37:47-56, 1992.

CLARK, G.M.; ZAMENHOF, S.; van MARTHENS, E.; GRAUEL, L.; KRUGER, L. The effect of prenatal malnutrition on dimensions of cerebral cortex. Brain Res., 54:397-402, 1973.

CONBOY, V.B.; SANTER, R.M.; SWIFT, G.L. Effects of prenatal undernutrition on prevertebral sympathetic neurons in the rat: a morphological and fluorescence histochemical study. J. Anat., 154:47-53, 1987.

CRAGG, B.G. The development of cortical synapses during starvation in the rat. Brain, 95:143-150, 1972.

CROWE, R.; HAVEN, A.J.; BURNSTOCK, G. Intramural neurons of the guineapig urinary bladder: histochemical localization of putative neurotransmitters in cultures and newborn animals. J. Auton. Ner. System., 15:319-339, 1986.

DAIL Jr., W.; EVAN Jr., A.P.; EASON, H.R. The major ganglion in the pelvic plexus of the male rat. Cell Tissue Res., 159:49-62, 1975.

DAVISON, A.N. \& DOBBING, J. Myelination as a vulnerable period in brain development. Brit. med. Bull., 22:40-44, 1966. 
DEO, K.; BIJLANI, V.; DEO, M.G. Effects of malnutrition on cell genesis and migration in developing brain in rats. Exp. Neurol., 62:80-92, 1978.

EAYRS, J.T. \& HORN, G. The development of cerebral cortex in hypothyroid and starved rats. Anat. Rec., 121:53-61, 1955.

FALANGOLA, M.F.; QUEIROZ, A.C.; ANDRADE, S.G.; SADIGURSKY, M. The involvement of the central nervous system in acute chagasic infection. Comparative histopathologic and immunologic study in three species of animals infected with three strains of T. Cruzi. Mem. Inst. Oswaldp Cruz, $85: 14,1990$.

FEHÉR, E.; CSÁNYI, K.; VAJDA, J. Ultrastructure of the nerve cells and fibers in the urinary bladder wall of the cat. Acta Anat., 103:109-118, 1979.

FERRAZ-DE-CARVALHO, C.A.; DE-SOUZA, R.R.; OLIVEIRA, C.A.; HAMADA, G.S.; FERNANDES, P.M.P. A quantitative study on the myenteric plexus of the distal end of the duodenum and the proximal part of the jejunum. Gegenbaurs Morphol. Jahrb., 129:51-56, 1983.

FILOGAMO, G. \& VIGLIANI, F. Ricerche sperimentali sulla correlazione tra estensione del territorio di ennervazione e grandezza e numero delle cellule gangliari del plesso mienterico (di Auerbach) nel cane. Riv. Patol. nerv. ment., 75:41-62, 1954.

FURNESS, J.B. \& COSTA, M. The enteric nervous system. New York. Churchill Livingston. 1987, 290 p.

GABELLA, G. Detection of nerve cells by a histochemical technique. Experientia, 25:218-219, 1969. 
GABELLA, G. Neuron size and number in the myenteric plexus of the newborn and adult rat. J. Anat., 109:81-95, 1971.

GABELLA, G. Structure of the Autonomic Nervous System. Chapman \& Hall, London, 1976.

GABELLA, G. Innervation of the gastrintestinal tract. Int. Rev. Cytol., 59:129$193,1979$.

GABELLA, G. On the musculature of the gastro-intestinal tract of the guinea-pig. Anat. Embryol., 163:135-156, 1981.

GABELLA, G. \& TRIGG, P. Size of neurons and glial cells in the enteric ganglia of mice, guinea-pig, rabbits and sheep. J. Neurocytol., 13:49-71, 1984.

GABELLA, G \& HALASY, K. On the nerve plexus of the chicken gizzard. Anat. Embryol., 177:97-103, 1987a.

GABELLA, G. The number of neurons in the small intestine of mice, guinea-pig and sheep. Neuroscience, 22(2):737-752, $1987 \mathrm{~b}$.

GABELLA, G.; TRIGG, P.;Mc PHAIL, H. Quantitative cytology of ganglion neurons and satellite glial cells in the superior cervical ganglion of the sheep. Relationship with ganglion neurons size. J. Neurocytol., 17:753$769,1988$.

GABELLA, G. Fall in the number of myenteric neurons in ageing guinea-pig. Gastroenterology, 96:1487-93, 1989.

GABELLA, G. On the plasticity of form and structure of enteric ganglia. J. Auton. Nervous Sys., 30:859-866, 1990a. 
GABELLA, G. Intramural neurons in the urinary bladder of the guinea-pig. Cell tissues Res., 261:231-237, 1990b.

GAETANI, S.; MENGHERI, E.; ROSSI, A.; SPADONI, M.A.; TOSCHI, G. Long term protein deficiency in adult rats. Effects on different proteins of a sympathetic ganglion. Neurochemical Res., 2:439-448, 1977.

GERSHON, M.D.; ERDE, S.M. The nervous system of the gut. Gastroenterology, 80:1571-1594, 1981.

GILPIN, C. J.; DIXON, J.S.; GILPIN, S.A.; GOSLING, J.A. The fine structure of the wall of the human urinary bladder. J. Anat., 137:705-713, 1983.

GRAPUlin, G.; OTTOLENGHI, A.; FAGIOLO, U.; VECELliO, A. Studio sull'innervazione terminale delle vie biliari extraepatiche del cane. Nota III: L'innervazione adrenergica al microscopio a fluorescenza prima e dopo resezione delle vie afferenti vegetative. Arch. 'De Vecchi' per l'anat. patol. med, clin., 51:785-790, 1968.

GUNN, M. Cell types in the myenteric plexus of the cat. J. Comp. Neurol., 111:83-100, 1959.

GUNN, M. Histological and histochemical observation on the myenteric and submucous plexuses of mammals. J. Anat., 102:223-239, 1968.

HIRST, G.D.S.; HOLMAN, M.E.; Mc KIRDY, H.C. Ywo descendong nerve pathways activated by distension of guinea-pig small intestine. J. Physiol., 244:113-127, 1975.

IRWIN, D.A. The anatomy of Auerbach's plexus. Am. J. Anat., 9:161-166, 1931. 
KÖBERLE, F. Quantitative Pathologie des vegetativen Nervensystems. Wien Klin Wochenschr, 74:144-151, 1962.

KRAMMER, H.J; KÜHNEL, W. Immunohistochemistry for intermediate filaments in the enteric nervous system of the porcine small intestine. Ann. Anat., 174:275-278, 1992.

KRAMMER, H.J.; KARAHAN, S.T.; RUMPEL, E.; KLINGER, M.; KÜHNEL, W. Immunohistochemical visualization of the enteric nervous system using antibodies against Protein gene product (PGP) 9.5. Ann. Anat., 175:321-325, 1993.

LANGLEY, J.N. The autonomic nervous system. Cambridge, Heffer, 1921.

LEAMING, D.B. \& CAUNA, N. A qualitative and quantitative study of the myenteric plexus in the small intestine of the cat. J. Anat., 95:160-169, 1961.

LEPRI, E.R.; BRUSCHI, L.C.; MOURA, A.S. Efeitos da desnutrição protéica durante os períodos pré e pós natal no desenvolvimento cerebelar. Rev. bras. Ciên. morfol., 11(1):23-27, 1994.

MANNL, Von A.; POSPISCHIL, A.; DAHME, E. Der plexus submucous (Meiisner) beim Kalb. I. Licht and elektronmikroskopisch Unterschung der Nermalstruktur. Zentralbl. Veterinaremed. Rhie A., 31:585-600, 1984.

MASLENNIKOVA, L.D. On the relation between the motor function of the intestine and the gradient of its nervous elements. Bull. Exp. Biol. Med. U.S.S.R., 52:972-976, 1962. 
MATSUO, H. A contribution on anatomy of Auerbach's plexus. Jpn. Med. Sci. Anat., 4:417-428, 1934.

MECIANO FILHO, J.; CARVALHO, V.C.; DE SOUZA, R.R. Nerve cell loss in the myenteric plexus of the human esophagus in relation to age: A preliminary investigation. Gerontology, 41:18-21, 1995.

MEISSNER, G. Über die nerven der Darmwandt. Z. Rat. Med., 8:364-366, 1857.

OHKUBO, K. Studies on the intrinsec nervous system on the digestive tract. I. The submucous plexus of guinea-pig. Jpn. J. Med. Sci., 6:1-20, 1936a.

OHKUBO, K. Studien uber das intramurale nervensystem des verdaungskanals. III. Affe und Mensch. Jpn. J. Med. Sci., 6:219-247, 1936 b.

OKAMOTO, E.; UEDA, T. Embryogenesis of intra-mural ganglia of the gut and its relation to Hirchsprung's disease. J. Pediatr. Surg., 2:437-443, 1967.

OLIVEIRA, J.S.M., LLORACH-VELLUDO, M.A.S.; SALES-NETO, V.N. Megacolon in rats. Digestion, 45:166-171, 1990.

PALUMBI, G. Differenti aspetti del plesso di Auerbach in regione dei vari segment dell'intestino umano. Ric. Morfol., 13:538-562, 1933.

SANTER, R.M. \& BAKER, D.M. Enteric neuron numbers and sizes in Auerbach's plexus in the small and large intestine of adult and aged rats. J. Autonom. Nervous Syst., 25:59-67, 1988. 
SANTER, R.M. \& CONBOY, V.B. Prenatal undernutrition permanently decreases enteric neuron number and sympathetic innervation of Auerbach's plexus in the rat. J. Anat., 168:57-62, 1990.

SAUER, M.E. \& RUMBLE, C.T. The number of nerve cells in the myenteric and submucous plexuses of the small intestine of the cat. Anat. Rec., 96:373$381,1946$.

SCHABADASCH, A. Die Nerven des Magens der Katze. Z. Zell. Forsch. Mikrosk. Anat., 10:254-385, 1930.

SCHOFIELD, G.C. Anatomy of muscular and neural tissues in the alimentary canal. In: CODE, C.F. ed. Handbook of physiology. Washington, American Physiological Society, 1968. v.4. p. 1579-1627.

SHIMADA, M.; YAMANO, T.; NAKAMURA, T.; MORIKAWA, Y; KUSUNOKI, T. Effect of maternal malnutrition on matrix cell proliferation in the cerebrum of mouse embryo: an autoradiographic study. Pediatr. Res., 11:728-732, 1977.

SHRADER, R.E.; ZEMAN, F.J. Effect of maternal protein deprivation on morphological and enzymatic development of neonatal rat tissue. J. Nutr., 99:401-412, 1969.

SHRADER, R.E.; ZEMAN, F.J. Skeletal development in rats as affected by maternal protein deprivation and postnatal food supply. J. Nutr., 103:792801, 1973. 
SMITH, R.B.; TAYLOR, I.M. Observations on the intrinsec innervation of the human foetal oesophagus between the $10-\mathrm{mm}$ and $140-\mathrm{mm}$ crown-rump length stages. Acta Anat., 81:127-138, 1972.

STACH, W. \& SCHEUERMANN, D.W. Concentration of external noradrenergic axonal networks in the area of type III neuronal aggregates and dense capilary networks of the external submucosal plexus (Schabadasch) in the guinea-pig small intestine. Z. Mikrosk. Anat. Forsch., 99:617-626, 1985.

TAFURI, W.L. Auerbach's plexus in the guinea-pig. I. A quantitative study of the ganglia and nerve cells in the ileum, caecum and colon. Acta Anat., 31:522-530, 1957.

TANSY, M.F.; INNES, D.L.; MARTIN, J.S.; KENDALL, F.M. An evaluation of neural influence on the sphincter of Oddi in dog. Am. J. Dig. Dis., 19:423-437, 1974.

VAOS, G.C.; LISTER, J. Anatomic evidence for coexistence of cholinergic and adrenergic neurons in the developing human intestine: new aspects in the pathogenesis of developmental neuronal abnormalities. J. Pediatr. Surg., 23(3):231-236, 1988.

VAOS, G.C. Quantitative assessment of the stage of neuronal maturation in the developing human fetal gut - A new dimension in the pathogenesis of developmental anomalies of the myenteric plexus. J. Pediatr. Surg., 24(9):920-925, 1989.

YAMANO, T.; SHIMADA, M.; YAMASAKI, S.; GOTO, M.; OHOYA, N. Effect of maternal protein malnutrition on the developing cerebral cortex of mouse embryo: an electron microscopic study. Exp. Neurol., 68:228-239, 1980. 
YOSHIDA, M.M.; KRISHNAMURTHY, S.; WATTCHOW, J.B.; FURNESS, J.B.; SCHUFFLER, M.D. Megacolon in Myotonic Dystrophy caused by a degenerative neuropathy of the myenteric plexus. Gastroenterology, 95:820-827, 1988.

WALLINGFORD, J.C.; SHRADER, R.E.; ZEMAN, F.J. Effect of maternal protein-calorie malnutrition on fetal rat cerebellar neurogenesis. J. Nutr., 110:543-551, 1980.

WILSON, A.J.; FURNESS, J.B.; COSTA, M. The fine structure of the submucous plexus of the guinea-pig ileum . I. The ganglia, neurons, Schwann cells and neuropil. J. Neurocytol., 10:759-784, 1981a.

WILSON, A.J.; FURNESS, J.B.; COSTA, M. The fine structure of the submucous plexus of the guinea-pig ileum. II. Description and analysis of vesiculated nerve profiles. J. Neurocytol., 10:785-804, 1981 b.

WOZNIAK, W.; SKOWRONSKA, U. Comparative anatomy of pelvic plexus in cat, dog, rabbit, macaque and man. Anat. Anz., 120:457-473, 1967.

ZAMENHOF, S.; van MARTHENS, E.; GRAUEL, L. Prenatal cerebral development: effect of restricted diet, reversal by growth hormone. Science, 174:954-955, 1971.

ZANOTTO, A; OKUMURA, M. Alterações da motricidade do ileo isolado do camundongo chagásico. Rev. Inst. Med. Trop., 9:98-106, 1967.

ZEMAN, F.J. Effect on the young rat of maternal protein restriction. J. Nutr., 93:167-173, 1967. 


\begin{abstract}
In the present study we examine the normal morphology and the changes with age, Chagas' disease and undernutrition as well as the evolutive aspects of the visceral plexuses in different animal species.

The myenteric plexus consists of diverse size and shape ganglia according to the species or gut regions. In the human myenteric plexus each ganglion is surrounded by a well developed connective tissue capsule and inside the ganglia, oval or round neurons are present intermingled with many satellite cells. The neuronal density increases along the digestive tract. The largest neuron of the human myenteric plexus is observed in the esophagus.
\end{abstract}

Most of the myenteric neurons in aging subjects have an irregular and horny appearance. With age a neuronal density decrease and an increase in the ganglionic connective tissue are observed. The neuronal density decrease affects all ganglionic neurons according to the neuronal profile.

In the Chagas'disease a decrease in the neuronal density of the myenteric plexus is also verified. The mean of neuronal profile decreases in the animals with Chagas'disease. This aspect suggests the loss of an specific neuronal population.

Many neurons of the myenteric plexus are immature with a decrease in the neuronal profile in undernourished rats.

The meshes of the submucous plexus are more irregular than those of the myenteric plexus. The submucous ganglia are small and scattered, being the neuron area smaller than those of the myenteric plexus in the same gut region. The largest neuronal density of the submucous plexus is observed in the duodenum. The neuronal density of the 
myenteric plexus has a ratio of 2.5 to 4 neurons for each of the submucous plexus in the same region of the digestive tract.

Small ganglia and neuronal density are verified in the ganglionated plexus of the trachea and the gallbladder. The mean of neuronal profile is larger than that of the submucous plexus.

In the urinary bladder, the number, arrangement and distribution of intramural neurons are different according to the animal species. These observations suggest that the environment influences the intramural plexus diversity in same animal class. The neuronal gathering in large ganglia with the consequent increase in the neuronal density may be an evolutive aspect of the intramural plexus. 


\section{SEPARATAS}


TRABALHO I 


\title{
THE EFFECTS OF AGING ON THE MYENTERIC GANGLIA OF THE HUMAN COLON
}

\author{
O. A. Gomes, R.R. de Souza, E.A. Liberti \\ (Laboratory of Autonomic Neurobiology - Department of Anatomy, Institute of \\ Biomedical Sciences, University of São Paulo - São Paulo, SP - Brazil)
}

\section{AGING OF HUMAN COLONIC GANGLIA}

Correspondence to: Prof. Dr. Edson Aparecido Liberti, Departamento de Anatomia, Instituto de Ciências Biomédicas, Universidade de São Paulo, Av. Prof. Lineu Prestes 2415, Bio III - CEP 05508-900, PO BOX 66208 - CEP 05389-970, São Paulo, SP, Brasil. FAX (55-11) 813-0845. E Mail: EALibert, @ Biomed. ICB 2. USP. br 


\begin{abstract}
We examine the number of nerve cells in the myenteric plexus, and the collagen and elastic-related fibers of the myenteric ganglia in the human large intestine from subjects aged 20-35 and over 65 years. The total number of neurons decreases in old subjects by over $37 \%$. The perikaryal area of most of the neurons in both young and old subjects lies in the interval of from 101 to $200 \mu \mathrm{m}^{2}$. A ganglionic capsule is present and is thicker in the ganglia from old subjects, as are the septa within the ganglia. Both collagen and elastic-system fibers are more numerous in the ganglia from the old subjects. We conclude that the decrease in neuron density with age may affect the potential of the enteric nervous system to control various functional parameters of the large intestine.
\end{abstract}

Key words: Large intestine, myenteric ganglia, aging, collagen fibers, elastic-system fibers 


\section{Introduction}

Colon motility depends on the integrity of the gut wall nerves [1]. The control of the motility is still poorly understood $[2,3]$, however. Colonic transit slows in old persons [4, 5], constipation becoming one of the most common, chronic, digestive complaints in the elderly $[5,6]$. Although the reasons are not yet well known, a decrease in the number of neurons in the enteric nervous system with age is an hypothesis that cannot be discarded.

A significant reduction in the number of neurons in the myenteric plexus has been observed in the human small intestine and esophagus $[7,8]$ and in the digestive tracts of several species $[9,10]$. There are, however, no data concerning the number and size of neurons in the myenteric plexus of the human colon. Furthermore, there have been no observations on age-related changes of the ganglionic connective tissue, i.e., the collagen, elastic and elastic-related fibers (elaunin and oxytalan fibers) [11, 12, 13].

Given this lack of information, it was of interest to evaluate whether a substantial loss of neurons occurred in the different parts of the human colon with age and, if so, whether the connective tissue of the ganglia was affected.

\section{Materials and Methods}

Twelve complete large intestines obtained at necropsy from both male and female individuals with no known previous digestive pathologies, particularly Chagas' disease, were used. The subjects were divided according to age into two groups: GI (6 specimens aged 20-35 years) and GII (6 specimens aged over 65 years old). From each large intestine, annular segments of about $2 \mathrm{~cm}$ width were obtained from the middle part of the ascendent (AC) transverse (TC) descendent (DC) and sigmoid (SC) colons using as reference points the ileo-cecal valve, the right and left colonic flexures and the rectosigmoid junction, respectively. The length of the colon and the diameter of the AC, TC, DC and SC segments were measured. The segments were then subdivided in rings about $1 \mathrm{~cm}$ width (S1 and S2) which were opened through the taenia libera coli and processed separately as follows. 


\section{Neuron counts and neuron areas}

The S1 segments were immersed in a fixative solution (acetic formaldehyde) [11], dissected under a stereomicroscope and the mucosa, submucosa and part of the circular muscle layer were removed. Three, circular fragments, of $12.56 \mathrm{~mm}^{2}$ in area were then obtained from each segment with a puncturing device between the taenia mesocolica and taenia libera, the taenia libera and taenia omentalis and between the taenia omentalis and taenia mesocolica respectively, and immersed in the same fixative solution for $36 \mathrm{~h}$. After washing in phosphate buffer ( $\mathrm{pH} 6.9$ ), the portions were immersed for $24 \mathrm{~h}$ in a Giemsa stain solution [14], washed, dehydrated, cleared in xylene and carefully dissected, removing the remaining circular muscle layer. The material was then mounted in synthetic resin as wholemount preparations.

The number of neurons was obtained by examining the whole-mount preparations under a binocular microscope at $1000 \mathrm{X}$. All neurons present in each fragment were counted.

The profiles of 100 neural perikarya from each fragment were outlined and analyzed using a semi-automatic image analyzer (MINI-MOP KONTRON BILDANALYSE) with a camera lucida attached to the microscope. The results were analyzed by analysis of variance $(\mathrm{P}=0.05)$ followed by the Tukey multiple means test $(\mathrm{P}=0.05)[15]$.

\section{Collagen, elastic and elastic-related fibers of the ganglia}

Fragments of S2 were fixed for 48 to $72 \mathrm{~h}$ in a $10 \%$ formalin solution and were placed in $0.1 \mathrm{M}$ phosphate buffer ( $\mathrm{pH} \mathrm{7.4)}$ for $24 \mathrm{~h}$. They were dehydrated in an increasing alcohol series, immersed in benzol for $20 \mathrm{~min}$ and embedded in paraffin. Transverse sections of $10 \mu \mathrm{m}$ thickness were stained to visualize the elastic fibers using iron-hematoxylin [16, 17]. These and the elauninic fibers were detected by the Weigert technique [18]. The same method, preceded by oxidation with Oxon $\left(2 \mathrm{KHSO}_{5} \cdot \mathrm{KHSO}_{4} \cdot \mathrm{K}_{2} \mathrm{SO}_{4}\right.$-Dupont), was also used for both fiber types and for oxytalan fibers. Some sections were stained with Azo- 
Carmine [19] to reveal collagen fibers and by the picro-syrius (picric acid + syrius-red F3Ba, Verona Dyestuffs) $[20,21]$ method and examined by polarization microscopy to identify type I and III collagen fibers.

Other fragments of $\mathbf{S} 2$ were fixed in $2.5 \%$ glutaraldehyde with $0.2 \%$ tannic acid in phosphate buffer [22] and embedded in Epon-812 resin using routine procedures for transmission electron microscopy. Thin sections were examined in a Philips EM-301 electron-microscope.

\section{Results}

To ensure a minimal influence of preparation artifacts several special precautions were taken. Dissection in xylene diaphanizes the fragments making the ganglia easy to recognize and avoiding neuronal lesions. The Giemsa method provided adequate identification of the perikarya of the nerve cells in relation to the satellite and muscle cells (Figs. 1a, 1b); the nerve cell perikarya stained well and the nuclei stained as dark ring containing a black nucleolus (Fig. 1c).

\section{Qualitative observations}

In the whole-mount preparations, the distribution pattern of the myenteric ganglia was regular and uniform from one colonic segment to the next in both groups (GI, GII). The ganglia were variable in shape and size as a function of the number of ganglionic neurons. The neurons were densely arranged in ganglia from GI and were scattered in the ganglia from GII ganglia (Figs. 1a, 1b). The neurons were round or elongated in shape (Fig. 1c) and most were small in size. Satellite cells intermingled with ganglionic neurons were present in both groups (Figs. 1a-c)

The ganglia of the myenteric plexus are immersed in the thin connective septum between the longitudinal and circular muscle layers of the human large intestine. Each ganglion is surrounded by a connective tissue capsule. Thin septa, continuous with the capsule, are present within the ganglion, enveloping isolated or groups of neurons (Figs. le, 
$1 \mathrm{~g}$ ). The ganglionic capsule and the septa inside the ganglion are thicker in the old (GII) than in the young (GI) subjects (Figs 2a, b; 3a-c). Elastic and elastic-related fibers (elaunin and oxytalan fibers) are present in the ganglionic capsule and within the ganglion, and are more numerous in the ganglia from group GII (Figs. 1d, 1f, lh).

\section{Quantitative observations}

Neuronal density $\left(\mathbf{N} / \mathrm{cm}^{2}\right)$ and the total number of neurons estimated for both groups are given in Tables 1 and 2. Statistical analyses indicated no significant effects of the main factors age and colon regions $(\mathrm{P}=0.925)$ or among the regions in both groups $(\mathrm{GI}$ and GII). Significant effects between GI and GII were found only for total neuron density $(\mathrm{P}=0.035)$. A decrease of $37 \%$ in neuronal density was observed in group GII (old subjects).

The ranges of perikaryon area and the mean perikaryal area for groups GI and GII are shown in Figure 4 and table 3. Although the perikaryal area ranges from 18 to $537 \mu \mathrm{m}^{2}$ in group GI and from 19 to $650 \mu \mathrm{m}^{2}$ in group GII, most neurons in both groups have a perikaryal area in the interval from of 101 to $200 \mu \mathrm{m}^{2}$. Statistical analyses indicated no significant effects of the main factor region $(\mathrm{P}=0.958)$ between groups $\mathrm{GI}$ and $\mathrm{GII}(\mathrm{P}=$ $0.438)$ or for the interaction between age $x$ region $(P=0.864)$.

\section{Discussion}

The present study shows that a decrease in neuronal density with age occurs in the human colon as also reported for the human esophagus in which it varies from 22 to $62 \%$, and in the small intestine, with a loss of $38 \%[7,8]$. The relationship between the decrease in neuronal density and the increase in neuronal area suggesting passive expansion of the neurons, and interpreted as compensatory growth in the remaining neurons in an attempt to maintain the density of inervation as seen in the human esophagus and stomach [8], was not observed in the colon. Although the number of neurons decreases in group GII, 
measurements of neuron size suggest that the reduction in number with age affects all categories of neuron equally and implies that all intrinsic neuronal systems in the colon would be equally affected in old age. Thus, all the enteric neurotransmitter systems may be affected by the decline in neuron numbers; the potency of their varying actions on colonic function may consequently also be reduced [9]

Our results, based on the picro-syrius stain plus polarized light $[20,21]$, show the conspicuous collagen network of the ganglia formed mainly by type I collagen mixed with a small number of delicate type III, collagen fiber bundles. The ganglionic capsule in group GII is thicker than that in group GI and type I collagen is also present in greater amounts within the ganglia of group GII which characterizes a hardened structure.

The presence of great amounts of elastic and elastic-related fibers, mainly the elaunin fibers adapted to mechanical resistance [23] and the oxytalan fibers present in tissues of little elasticity [24] in group GII ganglia, suggests a less distensible structure. Although the elastic fibers may act as a reservoir of kinetic energy during distention of the colon wall, their increased calcium contents with age probably compromises elasticity [25]. This is an agerelated phenomenon also observed in other structures [26] which this appears to be a general and genetic process involving fibroblasts with unknown effects on neuronal function.

Nerve cell losses during life may could affect intestinal function and structure [7]. Neuronal body loss and axonal degenerations have been demonstrated in the surgically removed colons of young patients with severe idiopatic constipation [27, 28]. Partial denervation may cause dysfunction of the digestive tract like the increased sensitivity of smooth muscle such as seems to occurs in achalasia and diffuse esophageal spasm [8], and the alterations in the colonic muscle coat and mucosa that result from experimental megacolon [29]. In this light, the present study of the colonic myenteric plexus may help to elucidate why transit time in elderly persons with constipation is prolonged owing to segmental dismotility in the colon [1]. 
It would appear that constipation in the elderly is multifactorial in nature, resulting from decreased muscle tonus and motor function of the colon. The neurons of the myenteric plexus are involved in all these aspects. We thus postulate that the decrease in neuron number with age probably contributes to these alterations in colon function.

\section{Acknowledgments}

This study was supported by a grant from the Sandoz Foundation for Gerontological Research (LA-93-1-08) 


\section{References}

1. Harari D, Gurwitz JH, Minaker KL: Constipation in the elderly. JAGS 1993;41:11301140 .

2. Christensen J: The control of gastrointestinal movements: some old and new views. $\mathrm{N}$ Eng J Med 1971;285: 85.

3. Anuras S, Loening-Baucke V: Gastrointestinal motility in the elderly. JAGS 1984;32(5):386-390.

4. Madsen JL: Effects of gender, age, and body mass index on gatrointestinal transit time. Dig Dis Sci 1992;37:1548-1553.

5. Roberts D, Gelperin D, Wiley JW: Evidence for age-associated reduction in acetylcholine release and smooth muscle response in the rat colon. Am J Physiol 1994;267:515-522.

6. Merkel IS, Locher J, Burgio K, Towers A, Wald A: Physiologic and Psychologic characteristics of an elderly population with chronic constipation. Am J Gastroenterol 1993;88(11):1854-1859.

7. De Souza RR, Moratelli HB, Borges N, Liberti EA: Age-induced nerve cell loss in the myenteric plexus of the small intestine in man. Gerontology 1993;39:183-188.

8. Meciano Filho J, Carvalho VC, De Souza RR: Nerve cell loss in the myenteric plexus of the human esophagus in relation to age: A preliminary investigation. Gerontology 1995;41:18-21.

9. Santer RM, Baker DM: Enteric neuron number and sizes in Auerbach's plexus in the small and large intestine of young adult and aged rats. J Auton Nerv Syst 1988;25:59-67.

10. Gabella G: Fall in the number of myenteric neurons in aging guinea-pigs. Gastroenterology 1989;96:1487-1493.

11. Stadler R, Orfanos CE: Reifung und Alterung der elastischen Fasern. Arch Derm Res 1978;262:97-111.

12. Marsch WC, Schober E, Nürnberger F: Zur Ultrastruktur und Morphogenese der elastischen Faser und der aktinischen Elastose. Z Hautkr, Berlin (West) 1979;54:43-46.

13. Bittencourt-Sampaio $S$, Cotta-Pereira G: Distribuição das fibras elásticas, elaunínicas e oxitalânicas da derme superior em pele humana. A. Brasil. Dermat. 1971;46:333-347.

14. Barbosa JA: Histological technique for intramural ganglia in whole-mount preparations. Rev Bras Pesq Med Biol 1978; 11:95-97.

15. Zar, JH. Biostatistical Analysis. 2 ed.N. Jersey, Prentice Hall, 1984. 
16. Verhöff, FH: Some new staining methods of wide applicability including a rapid differential stain for elastic tissue. J Am Med Ass (Chicago) 1908, 50:876-877.

17. Cotta-Pereira, G, Rodrigo FG, Bittencourt-Sampaio S: Oxytalan, elaunin, and elastic fibers in the human skin. J Invest Derm 1976, 66:143-148.

18. Weigert C: Über eine Methode zur Färbung elastischer Fasern. Zentralbl Allg Pathol Anat (Jena) 1898;9: 289-292.

19. Romeis B: Mikroskopische Technik, 16. Aufl. München, Oldenbourg, 1968. 368-389.

20. Junqueira LCU, Cossermelli W, Brentani R: Differential staining of collagens type I, II and III by Sirius red polarization microscopy. Arch Histol Jpn 1978;41:267-274.

21. Junqueira LCU, Bignolas G, Brentani R: Picrossirius staining plus polarization microscopy, a specific method for collagen detection in tissue sections. J Histochem 1979;11: 447-455.

22. Cotta-Pereira G, Rodrigo FG, David-Ferreira JF: The use of tannic acid-glutaraldehyde in the study of elastic and elastic-related fibers. Stain Technol 1976;51:7-11.

23. Gawlik Z: Morphological and morphochemical properties of the elastic system in the motor organ of man. Fol Histochem Cytochem (Krakow) 1965;3:233-251.

24. Fullmer HM, Lillie RD: The oxytalan fiber: A previously undescribed connective tissue fiber. J Histochem. Cytochem 1958;6:425-430.

25. Robert B, Robert L: Aging of connective tissues. Front Matrix Biol, vol.1, p. 2-39 (Karger, Basel, 1973).

26. Robert C, Lesty C, Robert AM: Ageing of the skin: study of elastic fiber network modifications by computerized image analysis. Gerontology 1988;34:291-296.

27. Balazs M: Melanosis coli: Ultrastructural study of 45 patients. Dis Colon Rectum 1986;29:839-844.

28. Krishnamurthy S, Schuffler MD, Rohrmann CA: Severe idiopathic constipation is associated with a distinctive abnormality of the colonic myenteric plexus. Gastroenterology $1985 ; 88: 26-34$.

29. Alcântara FG, Oliveira JAM: Destruição neuronal no plexo de Auerbach em ratos chagásicos crônicos. Rev Inst Med Trop São Paulo 1964;6:207. 


\section{Figures}

1) a- Elongated myenteric ganglion from group GI with nerve cells showing different aspects (arrows). b- Myenteric ganglion from group GII showing less densely packed neurons (large arrows). Satellite cells are present among the neurons (small arrows). c- Two myenteric neurons of different size with an evident nucleolus (arrowheads). Sattelite cells are present between the neurons (arrow). d- A few elastic-system fibers in a ganglion capsule from group GI (large arrow) and within the ganglion (small arrow). e- Thick capsule (arrowheads) and septa (arrows) formed by type I collagen fibers inside a ganglion from group GII (N- nerve cell loci). $\mathbf{f}, \mathbf{h}$ - Increase in fibers of the elastic system in the capsule from group GII (arrows) and within the ganglion (arrowheads). g- Myenteric ganglion from group GI surrounded by a connective capsule (arrow). Thin septa enveloping isolated neurons or groups of neurons can be seen (arrowhead). (a-c: Whole-mount preparations, Giemsa technique. a- SC, 170X; b- TC, 170X; c- DC, 1.800X. d, h- Weigert technique with Oxon, TC, d- 300X, h- 780X. e- Picro-sirius technique, polarized light, AC, $720 \mathrm{X}$. fVerhoeff technique, AC 420X. g- Azan technique, DC, 1.100X).

2) a- Electron micrograph of a myenteric ganglion from group GI. The nucleus of a ganglionic neuron $(\mathrm{N})$ is seen as are adjacent satellite cells $(\mathrm{G})$. A few collagen fibrils $\left({ }^{*}\right)$ and elaunin fibers (arrowhead) are present surrounding the ganglion. b- Part of a neuron (arrowheads) in the myenteric ganglion from group GI with an adjacent elaunin fibers (E) and a few collagen fibrils (**). (a- 8.500X; b- 50.000X).

3) a- Electron micrograph of a myenteric ganglion from group GII. Numerous collagen fibrils $\left({ }^{*}\right)$ are present adjacent to a ganglionic neuron $(\mathrm{N})$. b, c- Ultrastructural aspects of a myenteric ganglion from group GII. A satellite cell with part of its nucleus is seen $(G)$ near the neuronal fibers $\left({ }^{*}\right)$, both surrounded by numerous collagen fibrils $\left({ }^{* *}\right)$. Elaunin fibers are also present (E). (a- 21.000X; b- 15.000X; c- 10.300X). 
4) Distribution of neuron profile areas in different regions of the human colon of young (GI) and aged (GII) subjects.

Table 1- Neuronal density $\left(\mathrm{N} / \mathrm{cm}^{2}\right)$ in diverse regions of the human large intestine (Mean \pm $\mathrm{SD})$.

Table 2- Mean of the total number of neurons in the myenteric plexus of human colon estimated for both young (GI) and old (GII) subjects. (Mean $\pm \mathrm{SD}$ ).

Table 3- Mean of perikaryon area of the myenteric neurons in the human colon for groups GI and GII. (Mean \pm SD). 


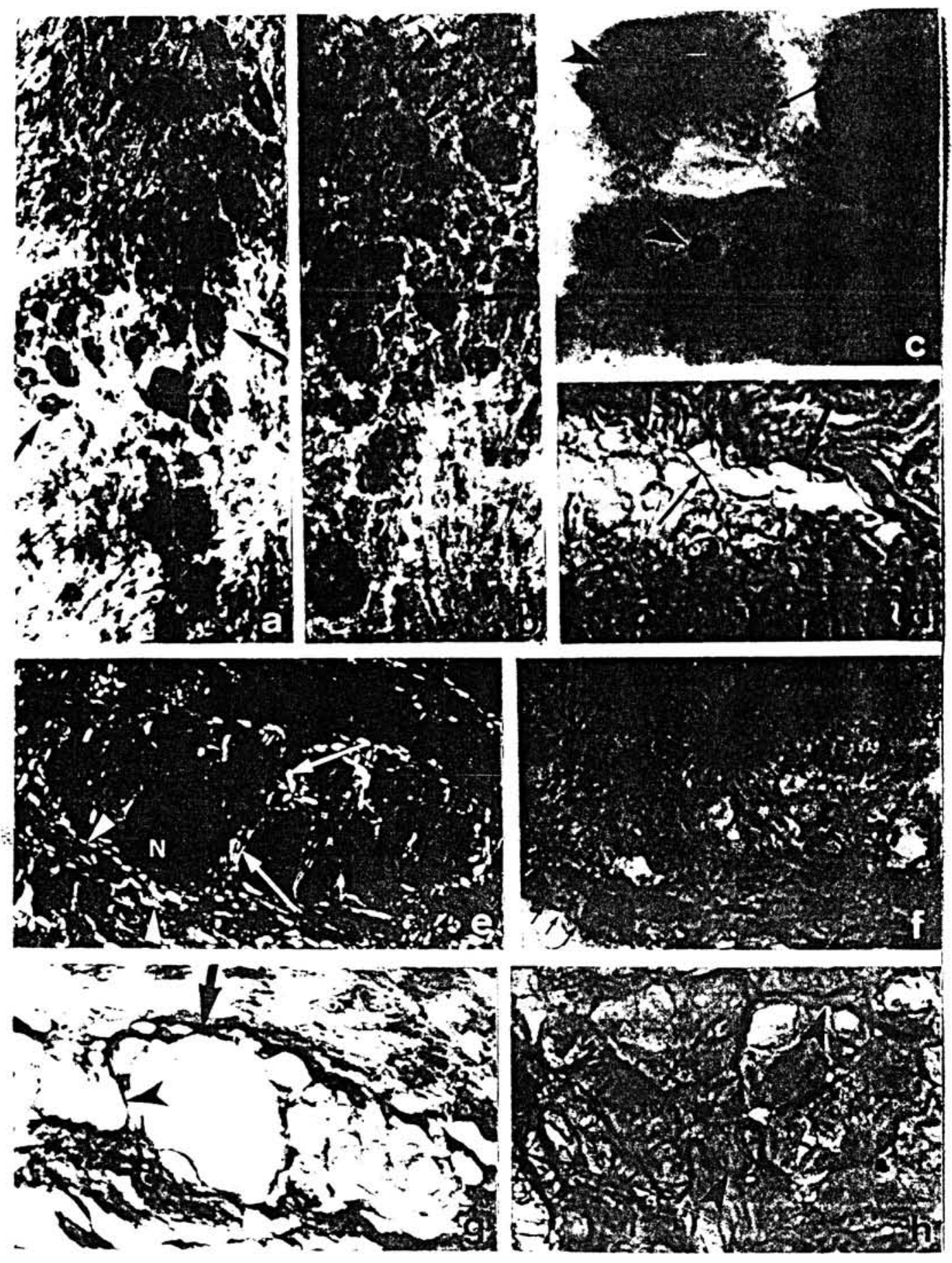




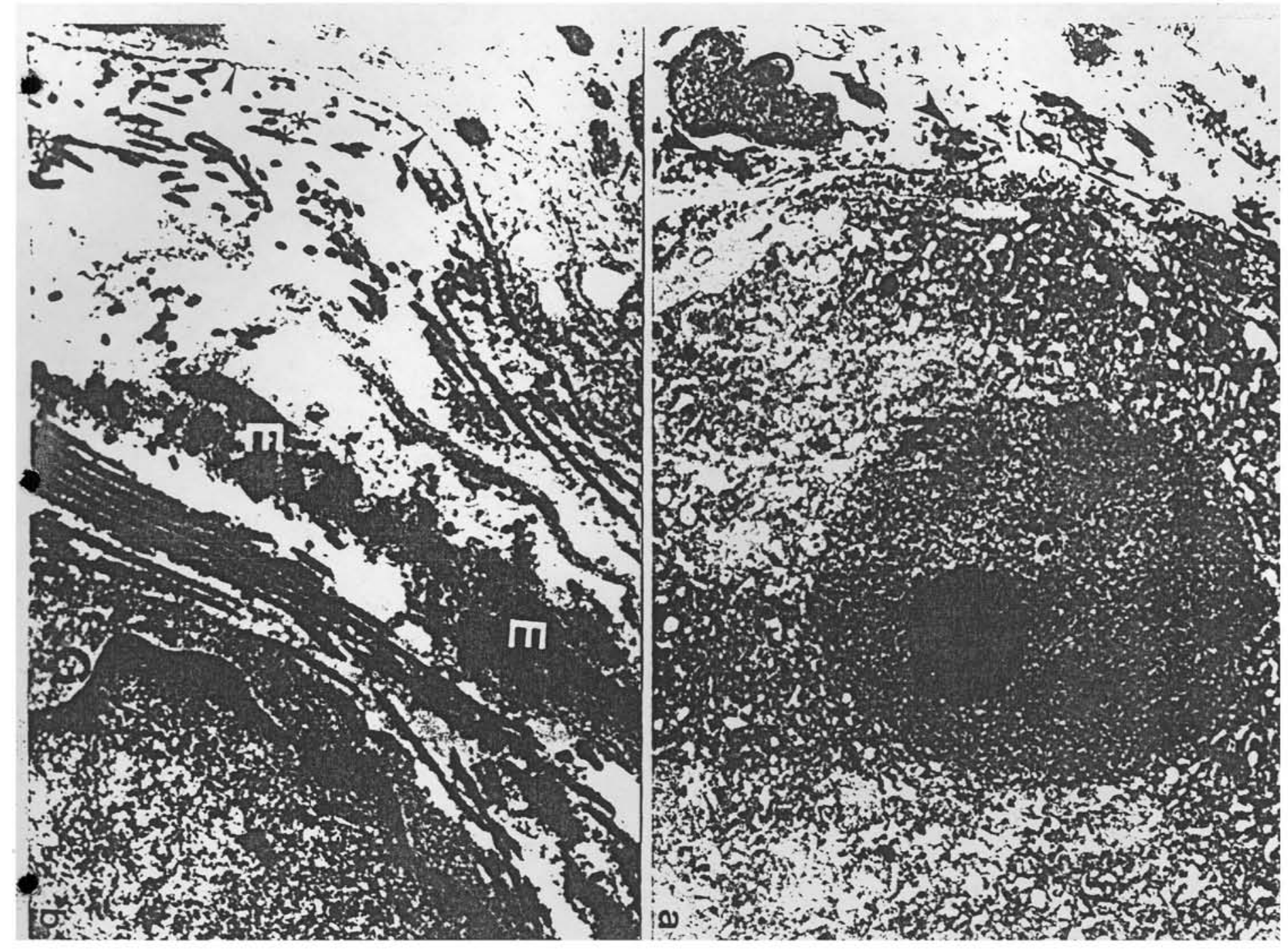




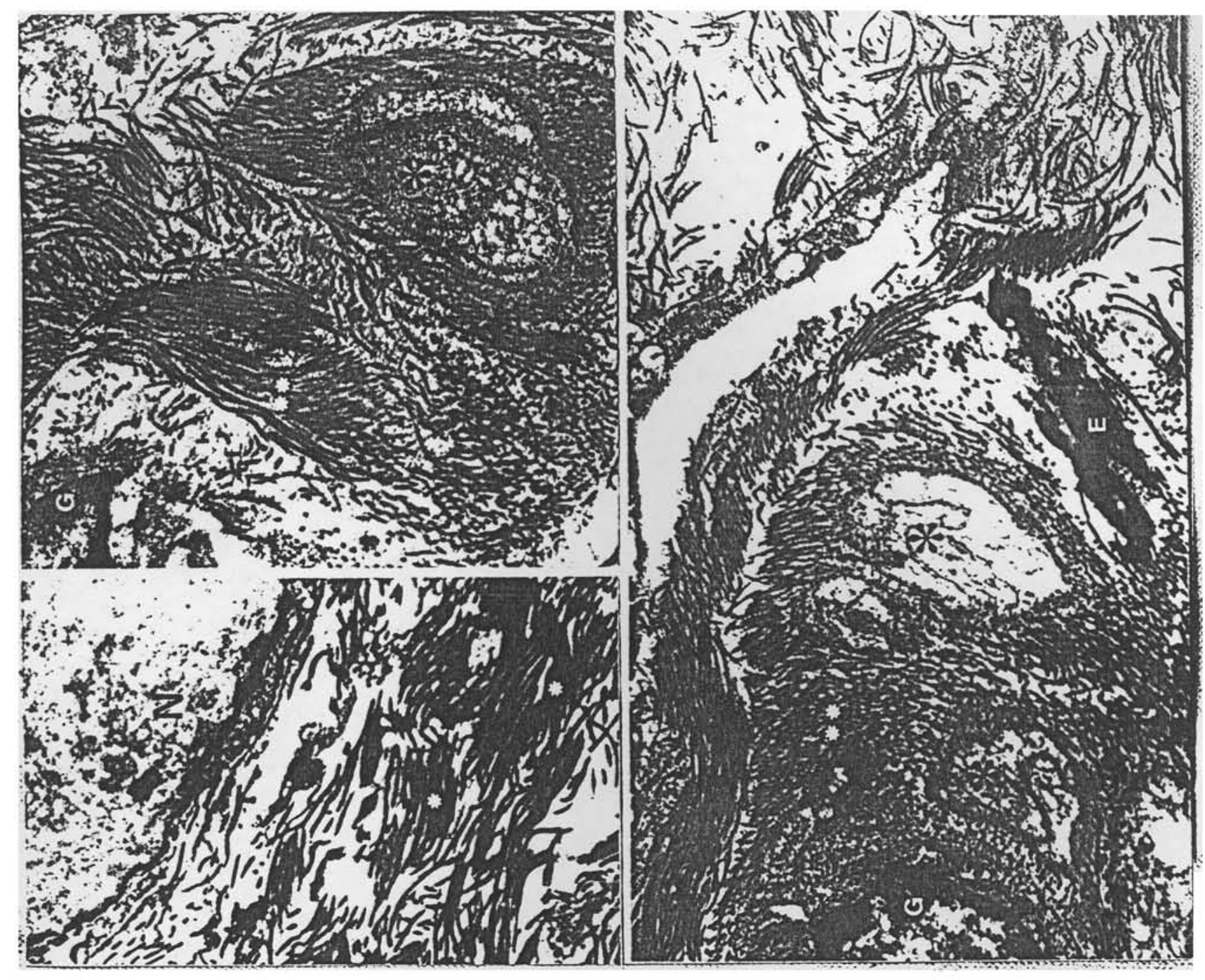




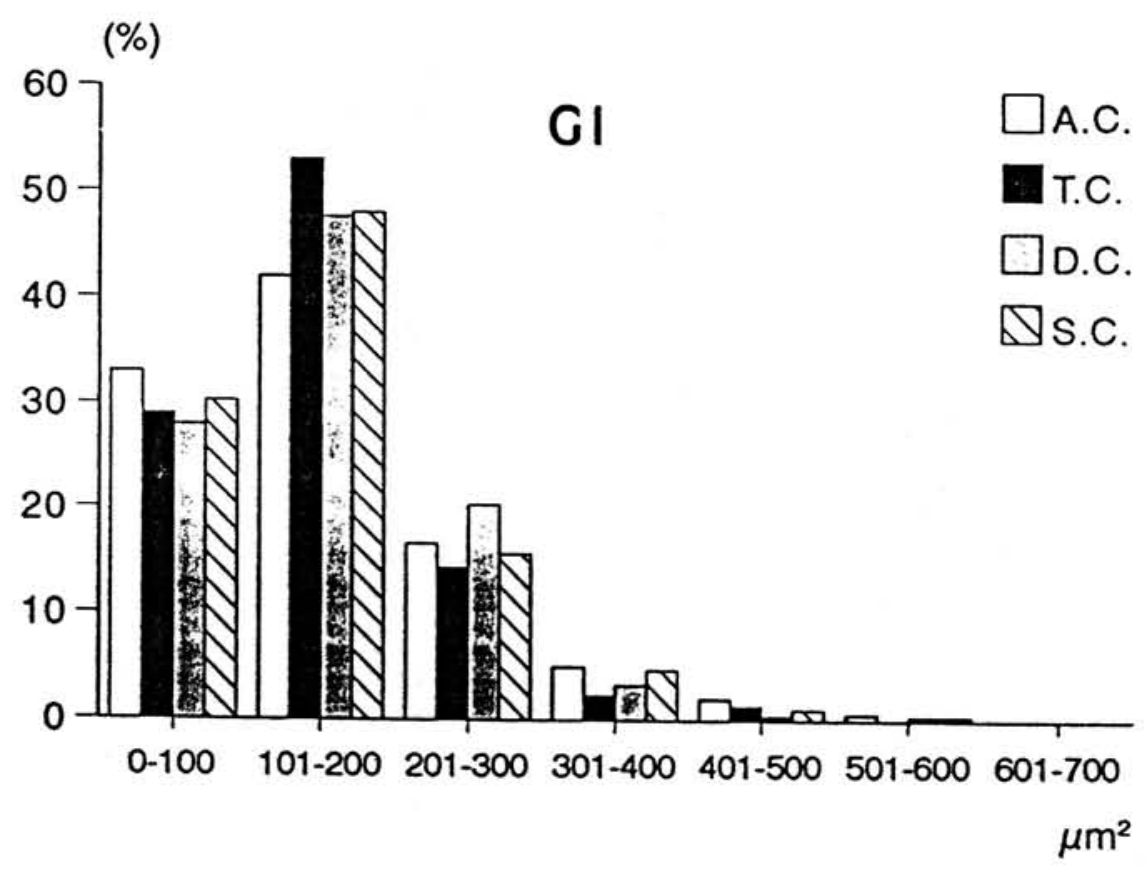

(\%)

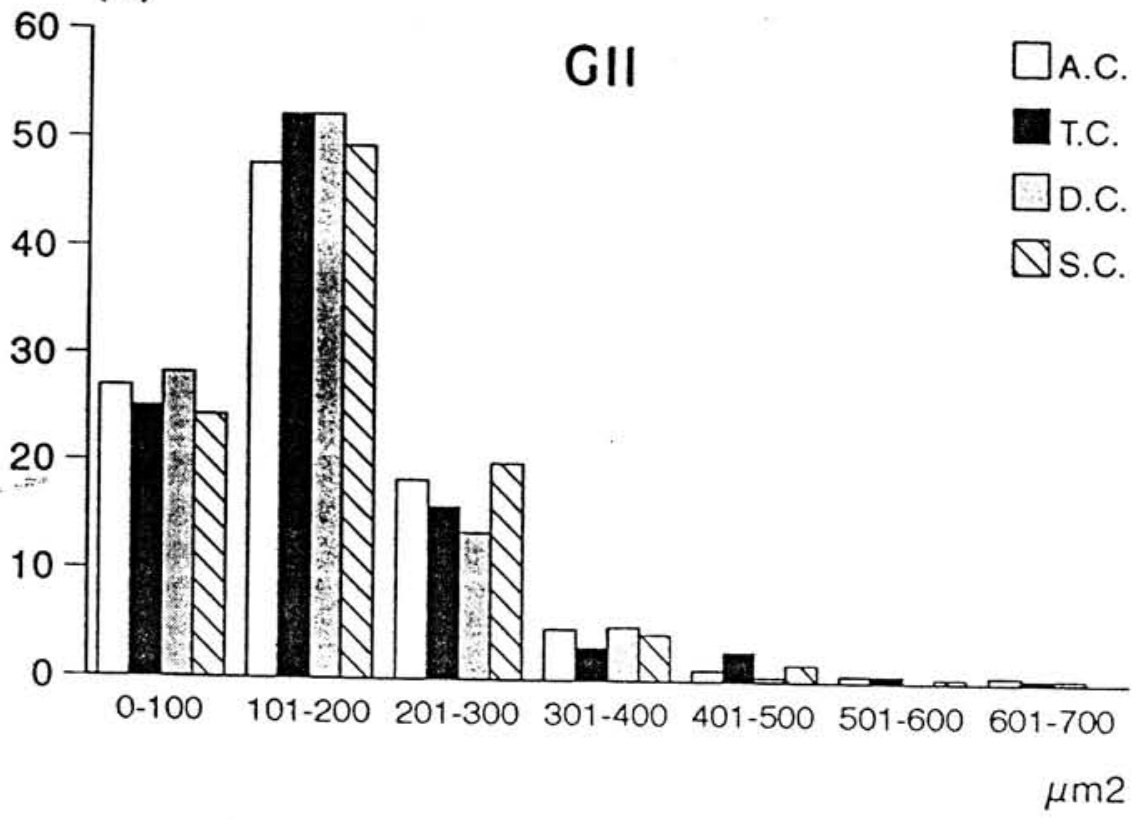




\begin{tabular}{|c|c|c|}
\hline & GI & GII \\
\hline AC & $54.560 \pm 10.345$ & $33.781 \pm 7.406$ \\
\hline TC & $49.377 \pm 13.973$ & $40.722 \pm 15.571$ \\
\hline DC & $42.581 \pm 15.382$ & $33.653 \pm 14.484$ \\
\hline SC & $38.711 \pm 15.495$ & $30.987 \pm 19462$ \\
\hline
\end{tabular}

\begin{tabular}{|c|c|c|}
\hline & GI & GII \\
\hline$X$ & 2.875 .300 & 1.915 .220 \\
\hline$S D$ & \pm 609.226 & \pm 244.467 \\
\hline
\end{tabular}

\begin{tabular}{|c|c|c|}
\hline & GI & GII \\
\hline AC & $153 \pm 93$ & $159 \pm 95$ \\
\hline TC & $146 \pm 72$ & $160 \pm 90$ \\
\hline DC & $152 \pm 77$ & $148 \pm 78$ \\
\hline SC & $151 \pm 83$ & $162 \pm 81$ \\
\hline
\end{tabular}




\section{TRABALHO II}




\title{
A QUANTITATIVE AND COMPARATIVE STUDY OF THE GANGLIONIC NEURONS IN THE MYENTERIC AND SUBMUCOUS PLEXUSES OF THE SMALL INTESTINE, AND IN THE INTRAMURAL PLEXUS OF THE GALL BLADDER OF THE GUINEA-PIG
}

\author{
ESTUDO QUANTITATIVO E COMPARATIVO DOS NEURÔNIOS GANGLIONARES \\ DOS PLEXOS MIENTÉRICO E SUBMUCOSO DO INTESTINO DELGADO E DO PLEXO \\ INTRAMURAL DA VESÍCULA BILIAR DE COBAIAS.
}

\author{
Edson Aparecido Liberti* \\ Luiza Miranda de Queiroz* \\ Eduardo Popeu* \\ Mario Alberto Marcondes Perito* \\ Ana Maria Minarelli* \\ José Oscar Rodrigues de Moraes* \\ Romeu Rodrigues de Souza*
}

\begin{abstract}
LIBERTI, E.A. et al. - A quantitative and comparative study of the ganglionic neurons in the myenteric and submucous plexuses of the small intestine, and in the intramural plexus of the gall bladder of the guinea-pig. Rev. bras. Ciên. morfol., 11(2): 106114,1994
\end{abstract}

\begin{abstract}
Whole-mount preparations of guinea-pig small intestine and gall bladder stained using a modified Giemsa technique were used to estimate neuronal and ganglion density, and neuron area, within the wall of these organs. The myenteric ganglia were long and thin in the jejunum and ileum, and round, triangular, square, rectangular or distinctly elongated in the duodenum. Most of the myenteric neurons were also elongated. The submucosal plexus showed a remarkable regularity of pattern, and, compared with the myenteric plexus, had smaller ganglia which were variable in shape. The pattern of the intramural plexus resembles that of the submucosal plexus. In the myenteric plexus, there were no differences in ganglion density among the duodenum, jejunum and ileum. Neuronal density and the number of neurons/ganglion was greater in the duodenum. The mean ganglion and neuronal densities in the submucosal plexus were greater in the ileum and smaller in the jejunum. The number of neurons/ganglion decreased from the duodenum to the ileum. The intramural plexus of the gall bladder contained $1 \mathrm{ganglion} / \mathrm{mm}^{2}$ and 6 neurons $/ \mathrm{mm}^{2}$. In the myenteric plexus, neuron area ranged from 101 to $250 \mu \mathrm{m}^{2}$; in the submucous plexus, the value was from 51 to $250 \mu \mathrm{m}^{2}$ while in the intramural plexus, the areas of most neurons lay in the ranges of 201 to $300 \mu \mathrm{m}^{2}$ and 301 to 400 $\mu \mathrm{m}^{2}$. These results suggest significant differences in neuronal density in the myenteric plexus among the duodenum, jejunum and ileum, and significant differences between the submucosal and intramural plexuses.
\end{abstract}

Key words: Enteric nervous system, Small intestine, Gall bladder, Neuron size.

\section{INTRODUCTION}

Quantitative morphometric and histological studies of the myenteric and submucous plexuses refer mainly to mammalian species. There are many neurons in these plexuses, which vary among the species as regards the different parts of the digestive tract, and in the various organs(IRWIN, 1931; PALUMBI, 1933; MATSUO, 1934; OHKUBO, 1936a,b; SCHÄFER, 1938; SAUER \& RUMBLE, 1946; CAVAZZANA \& BORSETTO, 1948; FILOGAMO, 1950; FILOGAMO \& VIGLIANI, 1954; TAFURI, 1957; JUNQUEIRA et al., 1958; BURNSTOCK, 1959; LEAMING \& CAUNA, 1961; MASLENNIKOWA, 1962; GUNN, 1968; GABELLA, 1971, 1984, 1987, 1989, 1990; RADLE et al., 1978; ALI \& McLELLAND, 1980;
CHRISTENSEN \& ROBINSON, 1982; DE SOUZA et al., 1982, 1988, 1993; SANTER \& BAKER, 1988; LIBERTI et al., 1994). Quantitative parameters of neurons in the myenteric and submucous plexuses vary according to the species. Thus, in the small intestine of the cat, neuronal density in the submucous plexus is approximately twice that of the myenteric plexus (SAUER \& RUMBLE, 1946). This relationship is inverted when the guinea-pig small intestine is analyzed (GABELLA, 1971).

In view of these observations, it was of interest to compare aspects of the myenteric and submucous plexuses in each component of the small intestine (duodenum, jejunum and ileum), and the intramural plexus of the gall bladder, a structure that is embryologically derived from the small intestine (GRAY, 1946).

* Department of Anatomy,Universidade de Sào Paulo

Correspondence: Liberti, E.A., Department of Anatomy. ICB III. Av. Prof. Lineu Prestes, 2415, CEP 05508-900, FAX 55-11-813-0845, São Paulo, SP. Brazil 
LIBERTI, E.A. et al. - A quantitative and comparative study of the ganglionic neurons in the myenteric and submucous plexuses of the small intestine, and in the intramural plexus of the gall bladder of the guinea-pig. Rev. bras. Cien. morfol.. 11(2): 106-114, 1994

\section{MATERIAL AND METHOD}

Five, male, adult guinea-pigs weighing $250-500 \mathrm{~g}$, without apparent pathologies of the digestive tract were used. The animals, sacrificed with an overdose of ether, were laparotomized and the gall bladder, together with the cystic duct and the entire small intestine, from pylorus to ileo-cecal junction, removed. Segments $3-\mathrm{cm}$ in length were obtained from each part of the small intestine as follows (GABELLA. 1981): immediately posterior to the pylorus (duodenum); anterior to the ileo-cecal junction (ileum) and $5 \mathrm{~cm}$ posterior to the pylorus (jejunum). The pieces were then ligated with cotton thread at either end and gently distended with Krebs' solution. mitroduced by a syringe at one end. After sufficient distension. the syringe needle was withdrawn and the ligature simultaneously tightened. The gall bladder was emptied of its contents, filled with the same solution and the neck tied to maintain moderate distension.

Five circular fragments of $12.6 \mathrm{~mm} 2$ each were obtained from each segment of the small intestine from each animal. The gall bladders were opened and their areas measured. The fragments of the small intestine and the gall bladders were immersed for twelve hours in fixative solution (BARBOSA, 1978) and had the mucosa removed under a dissecting microscope. The intestinal fragments and the gall bladders were stained using a modified Giemsa technique (BARBOSA, 1978). They were dehydrated in an alcohol series, diaphanized with $\because y$ lene and the muscular and submucous layers of the intestinal fragments containing the neuron plexus, were dissected. During, dissection, the layers were carefully separated so as to leave the ganglia intact. They were mounted in resin as wholemount preparations.

The number of ganglia and neurons, and the profile of the nerve cells were obtained by examining whole-mount preparations under a binocular microscope at magnifications of 125 and $400 \mathrm{X}$. All ganglia and neurons present in circular fragments of the small intestine and in whole gall bladders were counted. The number of ganglia and cells per $\mathrm{mm}^{2}$ was then estimated for each segment of the small intestine and for the gall bladder.

The profiles of 300 nerve perikarya for each segment of the digestive tract and 100 for each gall bladder were outlined on drawing paper using a camera lucida attached to the microscope and the areas of these cell bodies were calculated using a digitizing pad and stereometric analysis on a personal computer. Data were analysed statistically by the KruskalWallis non-parametric test (ZAR, 1984).

\section{RESULTS}

In order to ensure a minimum influence of technical factors upon results, some special cautions were taken. Dissecon in xylene phase clarifies the fragments avoiding neuronal lesions. The Giemsa method provided adequate identification of the perikarya of the nerve cells in relation to the satellite and muscle cells. The ganglia were easily recognized; the nerve cell perikarya stained well and the nuclei stained as a dark ring containing a black nucleolus. The stained neurons of the three plexuses formed a population fairly homogeneous in size and spherical in shape. In the intramural plexus of the gall bladder, the overall staining intensity of the neurons was lower than in the myenteric and submucous plexuses of the small intestine.

\section{Qualitative observations of the ganglia and neurons}

In the myenteric plexus, the pattern of distribution was regular and uniform from one intestinal segment to the next. The ganglia were long and thin. their long axis almost invariably lying parallel to the circumference of the gut and their width not greater than three or four neurons (Fig. 1.a). In the duodenun, in addition to distinctly elongated ganglia, many round, triangular, square or rectangular ganglia were also observed (Figs. 1.b,c). Most of the myenteric neurons were elongated (Fig. 1.d) although many round neurons were seen in the duodenum.

In the submucous plexus, the ganglia were smaller and round or elongated in shape and distinctly separated (Figs. 2.a,b,c). The neurons were generally smaller with roundish or pear-like profiles, with few neurons as elongate as many those in the myenteric plexus (Fig. 2.d).

The intramural plexus of the gall bladder resembled the submucous plexus, with neurons variable in shape (Figs. 2.e,f,g).

\section{Neuron counts}

In the myenteric plexus, there were $2 \pm 0.6$ ganglia $/ \mathrm{mm}^{2}$ $\left(\mathrm{G} / \mathrm{mm}^{2}\right)($ mean $\pm \mathrm{SD})$ in the duodenum, jejunum and ileum; there were $189 \pm 23.1$ neurons $/ \mathrm{mm}^{2}\left(\mathrm{~N} / \mathrm{mm}^{2}\right)$ in the duodenum, $140 \pm 10.1$ in the jejunum and $140 \pm 10.7$ in the ileum; there were $94 \pm 17.8$ neurons/ganglion $(\mathrm{N} / \mathrm{G})$ in the duodenum, $86 \pm$ 8 in the jejunum and $90 \pm 8$ in the ileum.

In the submucous plexus, there were $5 \pm 0.6 \mathrm{G} / \mathrm{mm}^{2}$ in the duodenum, $5 \pm 1$ in the jejunum and $7 \pm 0.6$ in the ileum; there were $50 \pm 4.3 \mathrm{~N} / \mathrm{mm}^{2}$ in the duodenum, $45 \pm 2.0$ in the jejunum and $60 \pm 2.2$ in the ileum and there were $9 \pm 0.6 \mathrm{~N} / \mathrm{G}$ in the duodenum, $10 \pm 0.6$ in the jejunum and $8 \pm 0.6$ in the ileum.

In the intramural plexus of the gall bladder, there was 1 $\mathrm{G} / \mathrm{mm} 2,6 \pm 0.6 \mathrm{~N} / \mathrm{mm}^{2}$ and $6 \pm 0.6 \mathrm{~N} / \mathrm{G}$.

These data on neuron $\left(\mathrm{N} / \mathrm{mm}^{2}\right)$ and ganglion densities $(\mathrm{G} /$ $\mathrm{mm}^{2}$ ) and the number of neurons/ganglion $(\mathrm{N} / \mathrm{G})$ in the myenteric, submucous and intramural plexuses are shown in Figure 3.

\section{Neuron size}

The ranges of perikaryon size, expressed as perikaryon area in all plexuses examined are shown in Figure 4. For the myenteric plexus, perikaryon area varied between 51 and 450 
LIBERTI, E.A. et al. - A quantitative and comparative study of the ganglionic neurons in the myenteric and submucous plexuses of the small intestine, and in the intramural plexus of the gall bladder of the guinea-pig. Rev. bras. Ciên. morfol., 11(2): 106-114, 1994

$\mu \mathrm{m}^{2}$ (Fig. 4.a) with mean ( \pm Standard Deviation) of $195.40 \pm$ 71.87 in the duodenum, $185.58 \pm 42.36$ in the jejunum and $147.0 \pm 38.45$ in the ileum (Fig. 4.d). For the submucous plexus neuron area varied between 51 and $250 \mu \mathrm{m}^{2}$ (Fig. 4.b) with
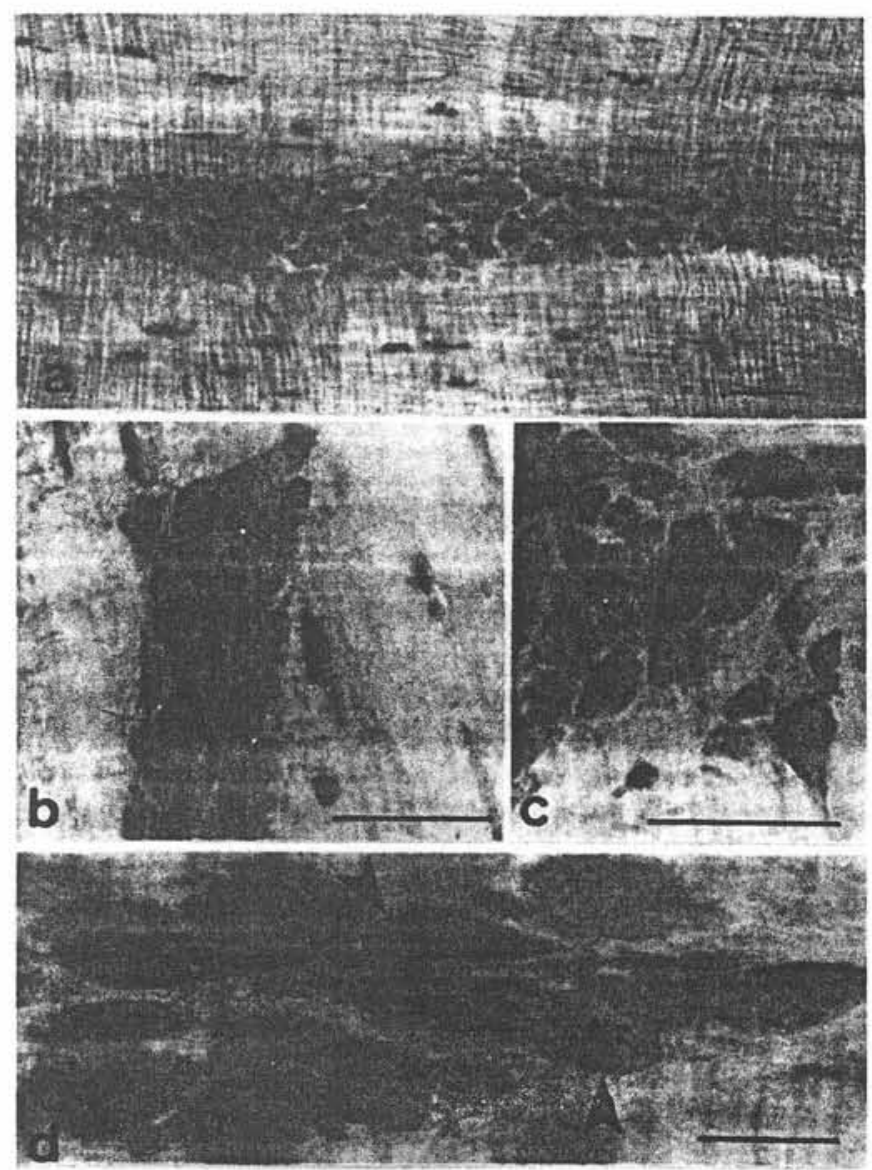

Figure 2- Submucous plexus. a,b,c) Three aspects of the ganglia- d) neurons with pear-like profiles (arrowheads). Intramural plexus. e,f,g) Small ganglia with neurons variable in shape. (Scale bar: a,c: $50 \mathrm{~mm}$; b,d: 25mm; e,f,g: $100 \mathrm{~mm}$ ). mean of $138.75 \pm 42.62$ in the duodenum, $136.52 \pm 73.05$ in the jejunum and $96.59 \pm 28.14$ in the ileum(Fig. 4.d). The variation in perikaryon area for the intramural plexus lay between 101 and $900 \mu \mathrm{m}^{2}$ (Fig. 4.c) with mean of $409.38 \pm 182.79$ (Fig. 4.d).

Figure 1- Myenteric plexus. a) Low-power aspect of the ganglion; b,c) highpower aspects of the ganglia observed in the duodenum; d) typical elongated aspect of the neurons (arrowheads). (Scale bar: a,b.c: $100 \mathrm{~mm}$ : d: $25 \mathrm{~mm}$ ).

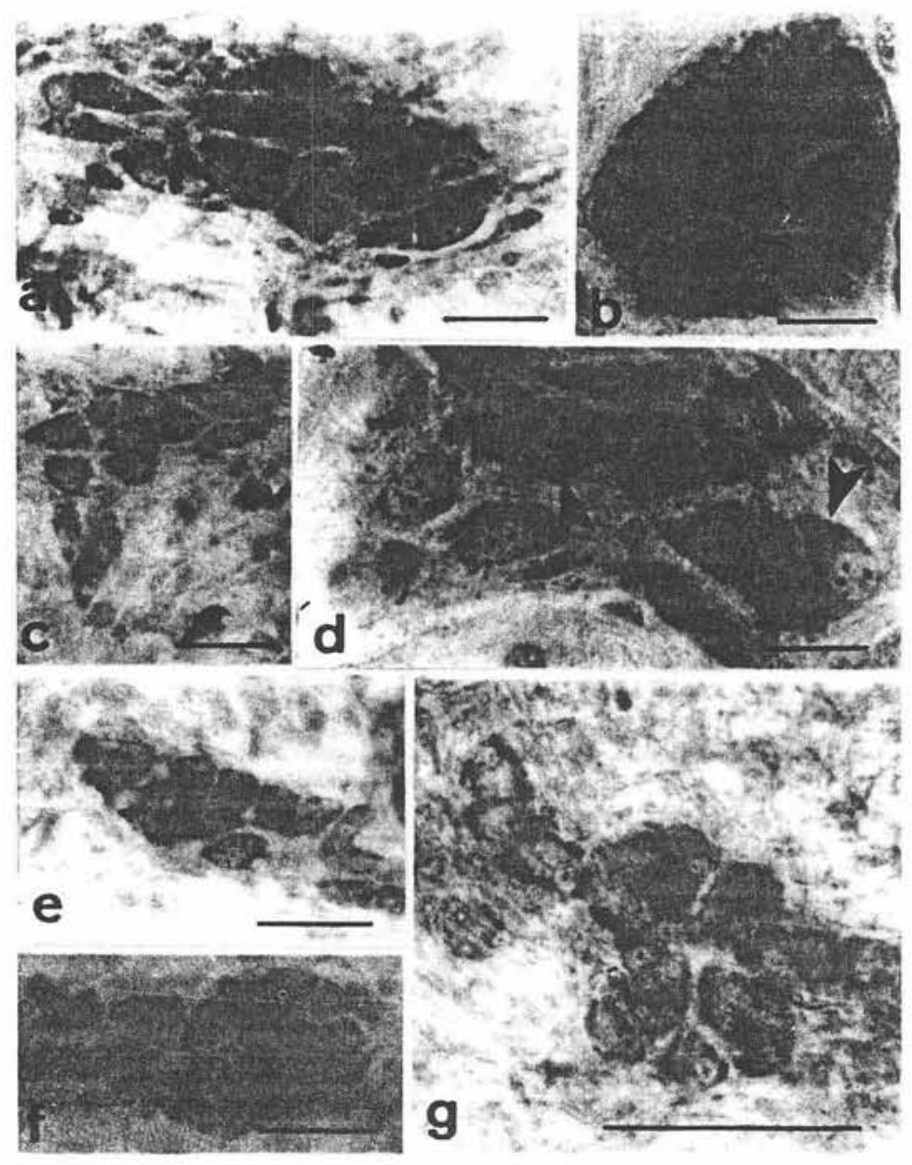


L.IBERTI, E.A. et al. - A quantitative and comparative study of the ganglionic neurons in the myenteric and submucous plexuses of the small intestine, and in the intramural plexus of the gall bladder of the guinea-pig. Rev: bras. Cienn. morfol., 11(2): 106-114, 1994
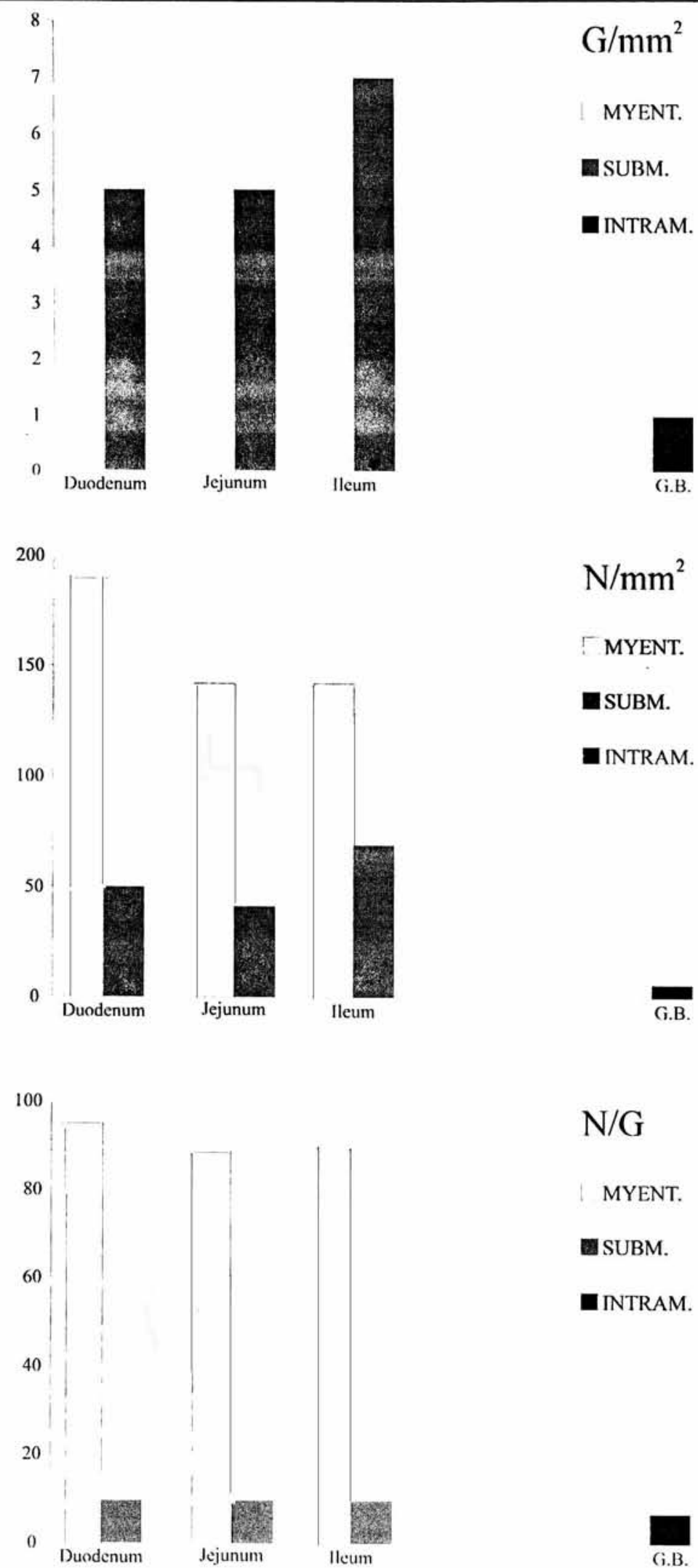

Figure 3- Ganglion $\left(\mathrm{G} / \mathrm{mm}^{2}\right)$ and neuron $\left(\mathrm{N} \mathrm{mm}^{2}\right)$ densities and the number of neurons ganglion $(\mathrm{N} / \mathrm{G})$ in the myenteric. submucous and intramural plexuses (Means $\pm \mathrm{SD}$ ). 

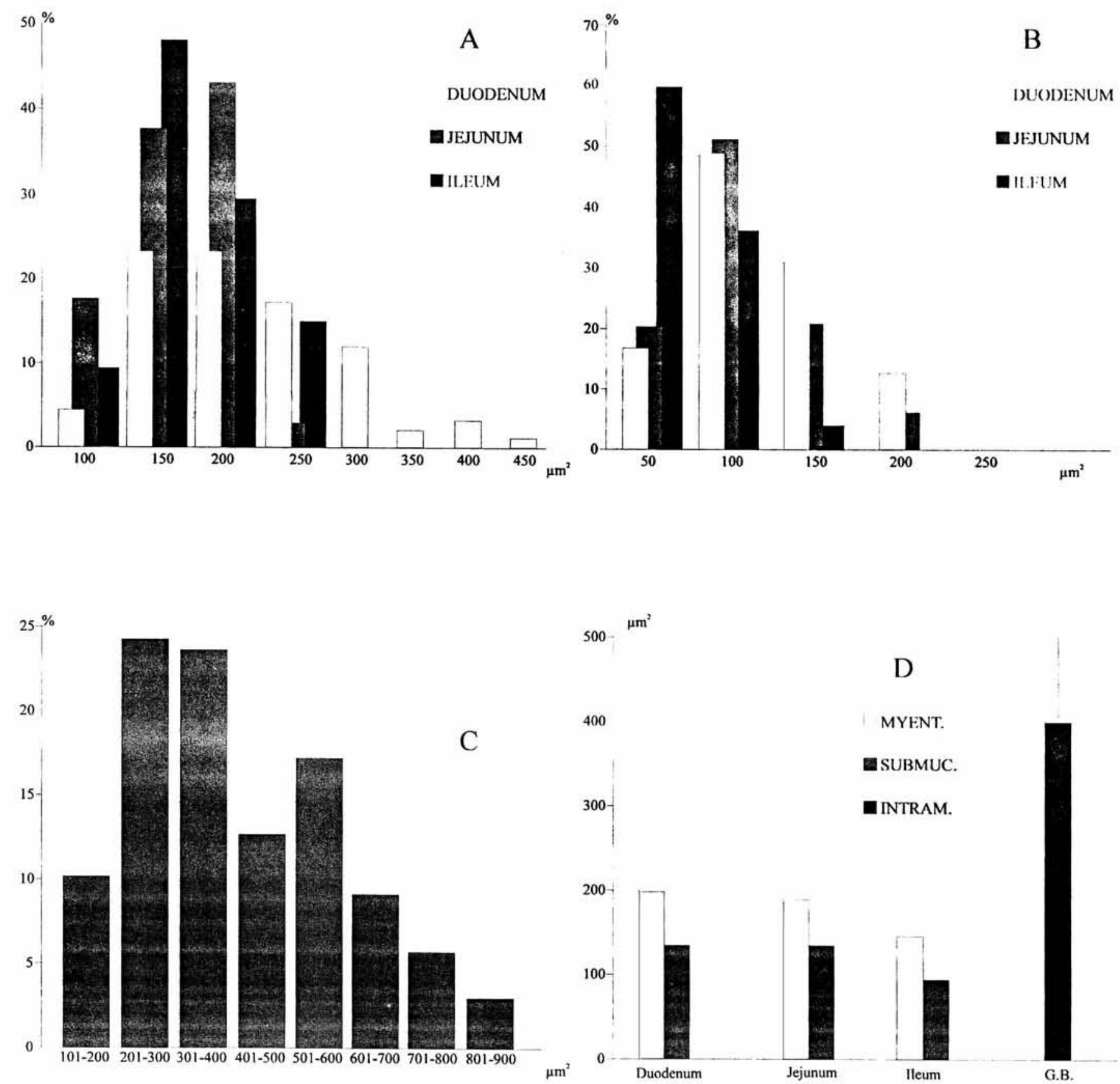

Figure +- Ranges of perikaryon size in the myenteric (A), submucous (B) and intramural plexuses (C): means \pm SD of perikaryon size in the three plexuses (D). 
IBERTI, E.A. et al. - A quantitative and comparative study of the ganglionic neurons in the myenteric and submucous plexuses of the small intestine, and in the intramural plexus of the gall bladder of the guinea-pig. Rev. bras. Cien. morfol., 11(2): 106-114, 1994

\section{DISCUSSION}

\section{The shape of the myenteric piexus}

The general pattern of the myenteric plexus, exhibiting elongated ganglia lying parallel to the circular musculature (IRVVIN, 1931; MATSUO, 1934; OHKUBO, 1936a; GABELLA, 1971, 1987), was observed mainly in the jejunum and ileum. In the duodenum, the ganglia were round, triangular, square or rectangular in form lying well apart from each other, as noted by GABELLA (1987) for the sheep myenteric nlexus.

The neurons are mainly fusiform, as already noted for the small intestine of the sheep (GABELLA, 1987) and fish (BURNSTOCK, 1959). In the duodenum, many neurons were spherical in shape, resembling those of the myenteric plexus of the mouse (GABELLA, 1987). The neuron areas ranged from 50 to $450 \mu \mathrm{m}^{2}$, with mean of $195.40 \mu \mathrm{m}^{2}$ in the duodenum, $185.58 \mu \mathrm{m} 2$ in the jejunum and $147.00 \mu \mathrm{m}^{2}$ in the ileum. These areas are larger than those reported for the myenteric plexus of the small intestine of the mouse and the guinea-pig $\left(100 \mathrm{~mm}^{2}\right)$ (GABELLA, 1987).

\section{The myenteric plexus: neuron counts}

Estimations of cell number carried out on whole-mount preparations eliminated embedding and sectioning of the tissues, which are responsible for some of the dificulties in counting neurons. Relating the ganglion or neuron counting with the fragments or whole viscera areas known prior to processing, the densities can be expressed independently of the degree of shrinkage due to processing and distorsions during dissection.

The mean ganglion density of 200 ganglia/ $\mathrm{cm}^{2}$ is much greater than that found in the opossum small intestine where the density is $37.2 / \mathrm{cm}^{2}$ in the jejunum and $52.5 / \mathrm{cm}^{2}$ in the ileum (CHRISTENSEN \& ROBINSON, 1982), and approximately twice that for the ileum of the guinea-pig (JUNQUEIRA et at., 1958 ). The mean N/G value obtained in the present study (86) is similar to that given by these authors $(81 \mathrm{~N} / \mathrm{G})$. Our data for neuronal density are also very different from those given for other species like the dog (FILOGAMO \& VIGLIANI, 1954), the opossum (LEAMING \& CAUNA, 1961), the sheep (GABELLA, 1987) and the rabbit (MASLENNIKOWA, 1962; RADLE, et al., 1978) where three or four times fewer neurons were observed. Although the density $\left(\mathrm{N} / \mathrm{mm}^{2}\right)$ in large species is less than that in small species, according to GABELLA (1987) there are obviously very large differences in the total number of myenteric neurons in different species, the sheep having about 80 times as many neurons as the mouse, since the increase in neuron number and intestinal size are allometric. The effect of this relationship is that. for a given area of serosal surface, there are markedly fewer neurons in a large-sized animal, such the sheep, than in a small-sized animal, such as the mouse.

Our data for mean neuronal density $\left(15,600\right.$ neurons $\left./ \mathrm{cm}^{2}\right)$ are similar to those given by TAFURI $(1957)\left(14,200 / \mathrm{cm}^{2}\right)$ and. although in accordance with IRWIN (1931) and OHKUBO (1936a) who showed the greatest number of neurons in the duodenum of the guinea-pig, the absolute values obtained by these authors and those of MATSUO (1934) and GABELLA (1981) are approximately half the value found in our study. According to GABELLA (1987), these results are greatly influeneed by the degree to which the intestinal wall is stretched during preparation. This makes comparison among the different investigations, difficult.

The great density of neurons in the duodenum is probably related to the thickness of the muscular wall in this region which is twice that observed in the jejunum and ileum (GABELLA, 1990). This hypothesis is reinforced by the fact that in the sphincters of the digestive tract where a greater number of muscle fibers is observed, neuronal density is also greater (IRWIN, 1931;MATSUO, 1934; GUNN, 1968).

\section{The morphology of the submucous plexus}

The ganglia are nodular and exhibit a regular pattern of distribution. They are quite different from those of the myentric plexus, being less polarized with respect to the axes of the intestine. The neurons are mainly spherical or pear-like in shape with a mean surface area of $138.75 \mu \mathrm{m}^{2}$ in the duodenum $136.52 \mu \mathrm{m}^{2}$ in the jejunum and $96.59 \mu \mathrm{m}^{2}$ in the ileum, showing a decrease in the surface area of the perikarya along the small intestine. Previous investigators have already noted that the submucosal neurons of the guinea-pig ileum are generally smaller (HILL, 1927; WILSON et al., 1981).

\section{The submucosal plexus. Neuron counts}

According to IRWIN (1931), there is a mean number of $3,600 \mathrm{~N} / \mathrm{cm}^{2}$ in the ileum of the guinea-pig; GABELLA (1987) has given a mean of $3,089 \mathrm{~N} / \mathrm{cm}^{2}$ for the entire guinea-pig small intestine. We found a mean of $5,000 \mathrm{~N} / \mathrm{cm}^{2}$ in the duodenum, $4,500 \mathrm{~N} / \mathrm{cm}^{2}$ in the jejunum and $6,000 \mathrm{~N} / \mathrm{cm}^{2}$ in the ileum, i.e., approximately twice that given by IRWIN (1931).

\section{Neuron shape and counts in the intramural plexus}

The overall appearance of this plexus is similar to that of the submucosal plexus of the duodenum (CAI \& GABELLA, 1983a). The gall bladder contains a mean of $6 \mathrm{~N} / \mathrm{mm}^{2}$, a low density also obtained by CAI \& GABELLA (1983a) when considering that the entire organ possesses an average of 367 ganglia which lie on the outer surface of the muscle coat. 
LIBERTI, E.A. et al. - A quantitative and comparative study of the ganglionic neurons in the myenteric and submucous plexuses of the small intestine, and in the intramural plexus of the gall bladder of the guinea-pig. Rev: bras. (ien. morfol.. 11(2): 106-114. 1994

\section{Final comparisons among the three plexuses}

In the small intestine of the cat, SAUER \& RUMBLE (1946) demonstrated the presence of three times more neurons in the submucous plexus than in the myenteric plexus. Our results show an inverse proportion, which is in accordance with GABELLA (1987) who demonstrated twice as many neurons in the myenteric plexus of the small intestine of the guinea-pig.

CAI \& GABELLA ( $1983 \mathrm{a}$ and b), GABELLA \& TRIGG (1984) noted that the ganglionic plexus of the gall bladder is not truly intramuscular but lies on the outer surface of the musculature. If the latter is derived from the muscularis mucosae. the subperitoneal connective tissue would then be equiralent to the intestinal submucosa. The ganglionic plexus thus would be the equivalent of the submucosal plexus of the intestine and not of the myenteric plexus, as is generally assumed. The pattern we observed confirms these assertions and those of SCHABADASCH (1930), OHKUBO(1936a), GUNN(1968), GABELLA (1979) and CAI \& GABELLA (1983a). Although the neuronal density is less than that of the submucous plexus, the mean neuron size in the intramural plexus exceeds that in the submucous plexus, apparently compensating for the lower density of neurons and furnishing a similar aspect to the ganglia of these plexuses.

A comparative study between the myenteric and submucous plexuses of the same region of the small intestine showed inversely proportional values when neuronal density was analyzed along the organ, i.e., while the density of neurons decreases in the myentenc plexus, it increases in the submucous plexus. The same may be assumed for the ganglionic density. Finally. although neuronal density was greater in the myenteric plexus, there is a constant proportion of $2.5-4$ neurons in the myenteric plexus for each neuron in the submucous plexus. How such direct proportionality occurs is a question that remains to be answered.

\section{Acknowledgement}

The authors are greatly indebted to Mr. Andres E. Pinuela for the invaluable photographic assistance.

LIBERTI, E.A. et al. - Estudo quantitativo e comparativo dos neurônios ganglionares dos plexos mientérico e submucoso do intestino delgado e do plexo intramural da vesícula biliar de cobaias. Rev. bras. Ciênc. morfol., 11(2): 106 - $114,1994$.

RESUMO: Preparados totais do intestino delgado e da vesicula biliar de cobaias, corados pelo método de Giemsa modificado, foram utilizadas a fim de se estimar as densidades neuronal e ganglionar e a área dos neurônios. da parede destes órgàos. Os gânglios mientéricos apresentaram-se longos e delgados no jejuno e no ileo, e arredondados, triangulares, quadrados, retangulares ou preferencialmente alongados no duodeno; A maioria dos neurônios mientéricos apresentaram-se alongados. $\mathrm{O}$ plexo submucoso mostrou um padrão basrante regular, e comparado com o plexo mientérico apresentou gânglios menores, variáveis quanto à forma. O padrão do plexo intramural assemelhou-se ao do plexo submucoso. No plexo mientérico, não ocorreram diferenças na densidade ganglionar entre o duodeno, o jejuno e o íleo. A densidade neuronal e o número de neurônios/gânglio foi maior no duodeno. A média da densidade ganglionar e a da densidade neuronal no plexo submucoso foram maior no ileo e menor no jejuno; o número de gânglios diminuiu do duodeno para o ileo. O plexo intramural da bexiga urinária apresentou I gânglio/m2 e 6 neurônios $/ \mathrm{m} 2$. No plexo mientérico, a área dos neurônios variou de 101 a $250 \mathrm{~m} 2$ : no plexo submucoso o valor foi de 51 a $250 \mathrm{~m} 2$. enquanto que no plexo intramural, as áreas da maioria dos neurônios concentraram-se entre 201 a $300 \mathrm{~m} 2 \mathrm{e}$ 301 a $400 \mathrm{~m} 2$. Estes resultados sugerem diferenças significantes na densidade neuronal entre o plexo mientérico do duodeno, do jejuno e do ileo, bem como entre os plexos submucoso do intestino delgado e intramural da vesicula biliar.

UNITERMOS: Sistema nervoso entérico, Intestino delgado, Vesícula biliar, Tamanho neuronal.

\section{REFERENCES}

ALI, H.A. \& McLELLAND, J. - Variations in neuron size in the avian intestinal myenteric plexus. Anat. Anz., 147:348-53, 1980.

BARBOSA, A.J.A. - Técnica histológica para gânglios nervosos intramurais em preparados espessos. Rev. Bras. Pesqui. Méd. BioL., 11: 95-7, 1978.

BURNSTOCK, G. - The innervation of the gut of the brown trout (Salmo trutta). Q.J Microsc. Sci., 100: 199-220, 1959.
CAI, W.Q. \& GABELLA, G. - Innervation of the gall bladder and billiary pathways in the guinea-pig. JAnal., 136(1): 97109, 1983a.

CAI, W.Q. \& GABELLA, G. - The musculature of the gall bladder and biliary pathways in the guinea-pig. $J$ Anat., 136(2): 237-250, 1983b.

CHRISTENSEN, J. \& ROBINSON, B.A. - Anatomy of the myenteric plexus of the opossum esophagus. Gastroenterology, 83: 1033-42, 1982. 
LIBERTI, E.A. et al. - A quantitative and comparative study of the ganglionic neurons in the myenteric and submucous plexuses of the small intestine, and in the intramural plexus of the gall bladder of the guinea-pig. Rev: bras. Cièn. morfol.. 11(2): 106-114. 1994

CAVAZZANA, P. \& BORSETTO, P.L. - Recherches sur l'aspect tificroscopique des plexus nerveux intramuraux et sur les modifications morphologiques de leurs neurones dans les divers traits de l'intestin humain pendant la vie. Acta Anat., 5: 17-41, 1948.

DE SOUZA, R.R.; FERRI, S.; FERRAZ DE CARVALHO, C.A.; PARANHOS. G.S. - Myenteric plexus in a fresh water teleost intestine. I- Quantitative study of nerve cells. Anat. Anz., 152: 359-62. 1982.

DFSOUZA.R.R.:FFRR A7.DFECARVALHO,C.A.:LIBERTI. E.A.:FUIIMURA.I.A. - Quantitativestudy on the myenteric plexus of the distal end of the human esophagus. Gegenhaurs Morphol. Jahrh., 134: 565-74, 1988.

DE SOUZA, R.R.; MORATELLI, H.B.; BORGES, N.; LIBERT1,E.A. - Age-induced nerve cell loss in the myenteric plexus of the small intestine in man. Gerontology, 39: 183188,1993

FILOGAMO, G. - Ricerche sul plesso mienterico. Arch. Ital. Anat. Embriol., 54: 401-12, 1950.

FILOGAMO,G.\& VIGLIANI, F. - Ricerche sperimentali sulla correlazione tra estensione del territorio di innervazione e grandezza e numero delle celule gangliari del plesso mienterico (di Auerbach) nel cane. Riv. Patol. Nerv. Ment., 75: 41-62, 1954.

GABELLA, G. - Neuron size and number in the myenteric plexus of the newborn and adult rat. J. Anat., 109: 81-95, 1971.

GABELLA, G. - Innervation of the gastrointestinal tract. Rev. Cytol., 59:129-93, 1979.

GABELLA, G. - On the musculature of the gastro-intestinal tract of the guinea-pig. Anat. Embryol., 163:135-156,1981.

GABELLA, G. \& TRIGG, P. - Size of neurons in glial cells in the enteric ganglia of mice, guinea-pigs, rabbits and sheep. J Neurocytol; 13: 49-71, 1984.

GABELLA, G. - The number of neurons in the small intestine of mice, guinea-pigs and sheep. Neuroscience, 22: 737-52, 1987.

GABELLA, G. - Fall in the number of myenteric neurons in aging guinea-pigs. Gastroenterology, 96: 1487-93, 1989.

GABELLA, G. - On the plasticity of form and structure of enteric ganglia. J Auton. Nerv. Syst., 30: 59-66, 1990.
GRAY, H. - Tratado de Anatomia Humana. $24^{a}$ ed (trad.), Rio de Janeiro, Guanabara Koogan, 1946. v.2, p. 1295-1306.

GUNN, M. - Histological and histochemical observations on the myenteric and submucous plexuses of mammals. $J$ Anal., 102: 223-39, 1968.

HILL. C. - A contribution to our knowledge of the enteric plexus. Phil Trans. R. Soc., 215: 355-387, 1927.

IRWIN, D.A. - The anatomy of Auerbach's plexus. Am. J. Anal.. 49.- 141-66. 1931.

JUNQUEIRA. L.C.U.:TAFURI. W.L.: TAFURI,C.P.-Quantitative and cytochemical studies on the intestinal plexuses of the guinea-pig. Exp. Cell. Res., 5(Suppl): 568-72, 1958.

LIBERTI,E.A.;DESOUZA,R.R.;PERITO,M.A.M.; ALVES, $\mathrm{N}$. Number, size and distribution of ganglion neurons in urinary bladder of rodents. Biol. Struct. Morpholog., 1994 (In Press).

LEAMING, D.B. \& CAUNA, N. - A qualitative and quantitative study of the myenteric plexus in the small intestine of the cat. J Anat., 95: 160-9, 1961.

MASLENNIKOVA, L.D. - On the relation between the motor function of the intestine and the gradient of its nervous elements. Bull. Exp. Biol. Med. U.S.S.R., 52-.972-76, 1962.

MATSUO, H. - A contribution on the anatomy of Auerbach's plexus. Jap. J. Med. Sci. Anat., 4: 417-28, 1934.

OHKUBO, K. - Studien über das intramurale Nervesystem des Verdaungskanals. II. Die Plexus myentericus and Plexus subserosus des Meerschweinchens. Jap. J. Med. Sci. Anat., 6: 21-37, 1936a.

OHKUBO, K. - Studien über das intramurale Nervensystem des Verdaungskanals. III. Affe und Mensch. Jpn. J. Med. Sci., 6: 219-47, 1936b.

PALUMBI, G. - Different aspetti del plesso di Auerbach in regione dei vari segmenti dellíntestino umano. Ric. Morfol., 13: 538-62, 1933.

RADLE, R.; WEISS, R.; STACK, W. - Die Nervenzallen in Der Magenwand Eine Lichtmikroskopische Unterschung an Laboratorium-streren. Dscht. Z. Verdau. Stoffwechchselkr., 38: 145-54. 1978.

SANTER, R.M.; BAKER, D.M. - Enteric neuron numbers and 
LIBERTI, E.A. et al. - A quantitative and comparative study of the ganglionic neurons in the myenteric and submucous plexuses of the small intestine, and in the intramural plexus of the gall bladder of the guinea-pig. Rev. bras. Ciên. morfol., 11(2): 100-114, 1994

sizes in Auerbach"s plexus in the small and large intestine of young adult and aged rats. J. Auton. Nerv. Syst., 25: 5967, 1988.

SAUER, M.E. \& RUMBLE, C.T. - The number of nerve cells in the myenteric and submucous plexuses of the small intestine of the cat. Anal. Rec., 96: 373-81, 1946.

SCHABADASCH, A. - Die Nerven des Magens der Katze. Z. Zeel. Forsch. mikrosk. Anat., 10: 254-385, 1930.

SCIÏFER, E. S. - The Essentials of Hystology. 14th ed., Philadelphia, Lea and Febiger. 1938. p.364.
TAFURI, W.L. - Auerbach's plexus in the guinea-pig. I.A. quantitative study of the ganglia and nerve cells in the ileum, caecum and colon. Acta Anat., 31: 522-30, 1957.

WILSON, A.J.; FURNESS, J.B.; COSTA, M. The fine structure of the submucous plexus of the guinea-pig ileum. I. The ganglia, neurons, Schwan cells and neuropil. JNeurocytol., 10: $759-784,1981$.

ZAR, J. H. - Biostatistical Analysis. $2^{\text {a }}$ ed, N. Jersey, PrenticeHall, 1984. 
TRABALHO III 
Mienteric plexus in a wild mouse

L.B.M. Maifrino et al.

\title{
MYENTERIC PLEXUS OF THE Calomys callosus DIGESTIVE TRACT. MORPHOMETRY AND ACETYLCHOLINESTERASE ACTIVITY
}

\author{
L.B.M. MAIFRINO, J.C. PRATES*, R.R. DE-SOUZA**, E.A. LIBERTI** \\ Instituto Dante Pazzanese de Cardiologia, São Paulo, SP, Brasil \\ *Departamento de Anatomia, Escola Paulista de Medicina, EPM, São Paulo, SP, Brasil \\ ** Departamento de Anatomia, Instituto de Ciências Biomédicas, Universidade de São \\ Paulo, USP, São Paulo, SP, Brasil
}

Correspondence: Dr. E.A. Liberti, Departamento de Anatomia, Instituto de Ciências Biomédicas, Universidade de São Paulo, USP, Av. Prof. Lineu Prestes, 2415, CEP 05389-970, FAX 011- 813-0845, São Paulo, SP, Brasil. 
Abstract

1. The myenteric plexus of the digestive tract of Calomys callosus was studied with a histochemical method that electively stains the nerve cells and with the acetylcholinesterase (AChE) histochemical technique in whole-mount preparations.

2. The neuronal density was $1,500 \pm 116 / \mathrm{cm}^{2}$ (mean $\pm \mathrm{SEM}$ ) in the esophagus; $8,900 \pm 1,518 / \mathrm{cm}^{2}$ in the stomach; $9,000 \pm 711 / \mathrm{cm}^{2}$ in the jejunum and $13,100 \pm 2,089 / \mathrm{cm}^{2}$ in the colon. The difference in neuronal density between the esophagus and other regions was statistically significant.

3. The neuronal cell profile area ranged from 45 to $1,100 \mu \mathrm{m}^{2}$. The difference in nerve cell size between the jejunum and other regions was statistically significant.

4. AChE-positive nerve fibers were distributed in the myenteric plexus which was formed by a primary meshwork of large nerve bundles and a secondary meshwork of finer nerve bundles. Most of the nerve cells displayed AChE activity in the cytoplasm with different reaction intensities.

5. The results show that the myenteric plexus of the Calomys callosus digestive tract conformed to the general pattern of gastrointestinal innervation demonstrated for mammals, mainly in mice.

Key words: enteric nervous system, myenteric plexus, Calomys callosus, morphometry, histochemistry. 
Introduction

The Calomys callosus, is a wild silvatic rodent native commonly found in South America and described in Brazil as harbouring Trypanosoma cruzi (Ribeiro, 1973). Laboratory infections of Calomys callosus result in much lower parasitemias and mortality than those of mice (Borges et al., 1992). They are similar in aspect to mice, except for a shorter tail and their fur is greyish brown. Size and weight are also comparable to that of mice for the first two months, with higher weight gain from then on reaching the maximum weight about $40 \mathrm{~g}$ (Borges et al., 1992). Although aspects of the biology of Calomys callosus have been studied, to our knowledge, no papers are available concerning the myenteric plexus of this rodent.

The objectives of the present investigation are: 1) to describe the myenteric plexus of the Calomys callosus digestive tract and, 2) to determine the presence of acetylcholinesterase (AChE), the number of neurons and the neuronal cell profile areas of the plexus.

\section{Material and Methods}

Seven male adult Calomys callosus weighing 30 to $35 \mathrm{~g}$ were used in this study. The animals were sacrificed with an overdose of ether and the following regions of the digestive tract were removed and washed in Krebs' solution (Gabella, 1987): distal part of the esophagus and stomach, and approximatelly $4 \mathrm{~cm}$ lengths of the jejunum and distal colon.

Each piece was then ligated with cotton thread at each end and gently distended with Krebs' solution which was introduced by a syringe at one end. When sufficient distension had been achieved, the syringe needle was withdrawn and the ligature at that end simultaneously tightened. After being left for 15-30 min. in Krebs' solution at room temperature, the segments were transferred to a permeabilizing agent ( $0.3 \%$ solution of Triton-X in Krebs' solution) during $15-90 \mathrm{sec}$., and were then 
transferred to 3 changes of Krebs' solution for about $10 \mathrm{~min}$. and then incubated for $30-90 \mathrm{~min}$. at $20^{\circ} \mathrm{C}$ in $20 \mathrm{ml}$ of incubation medium containing: Nitro blue tetrazolium (Sigma) $0.5 \mathrm{mg} / \mathrm{ml}$ in distilled water (25 parts), $0.1 \mathrm{M}$ sodium phosphate buffer $\mathrm{pH} 7.3$ (25 parts), distilled water (50 parts) and $\beta$-nicotinamide adenine dinucleotide (reduced form) $0.5 \mathrm{mg} / \mathrm{ml}$ (Gabella, 1987).

The development of the reaction was monitored under a dissecting microscope and it was stopped by immersion of the pieces in buffered $10 \%$ formalin, in which they were fixed for a minimum of $24 \mathrm{~h}$.

Laminar (whole-mount) preparations of the pieces were then made as follows: the segments were opened, the mucosa removed and the longitudinal muscle, with the myenteric plexus attached, was lifted at one corner and gently pulled off from the entire strip. After several washes in distilled water, three circular fragments (12.56 $\mathrm{mm}^{2}$ ) were obtained for each portion of the digestive tract and mounted in glycerol on a microscope slide, sealed with Entellan (Merck).

The number of neurons, and the profile of nerve cells, were obtained by examining the circular fragments under a binocular microscope at magnifications of $400 \mathrm{X}$. All neurons present in circular fragments were counted. The profiles of 300 nerve cell perikarya for each segment of the digestive tract were outlined on drawing paper using a camera lucida attached to the microscope. The areas of these nerve cell bodies were calculated using a digitizing pad. Data were statistically analysed by the Kruskal-Wallis non-parametric test (Zar, 1984) since the distribution of neurons is similar in the four portions studied. For the histochemical demonstration of acetylcholinesterase the "direct colouring" copper ferrocyanide method introduced by Karnovsky and Roots (1964) was used in fresh tissues prepared as whole-mount stretch preparations. 
Results

Qualitative observations

The myenteric ganglia were stained, and the plexus was already recognizable in all circular fragments. The staining technique employed resulted in sharply delimited perikarya and clear visualization of the nuclei.

The small ganglia of the esophagus with elongated or pear-like neurons with eccentrical nucleus were fusiform in profile and scatered along the organ (Fig.1, 2, 3). Large, elongated ganglia with neurons packed in a characteristically tight fashion were observed in the stomach (Fig.4), and in the jejunum and the colon there were a remarkable regularity of the pattern of the plexus with long and thin ganglia, being their long axis perpendicular to the circular muscular layer (Figs. 5, 6).

The pattern of cholinergic innervation was generally similar in the stomach, jejunum and colon. The AChE histochemical technique showed that the myenteric plexus consisted of a primary meshwork of relatively large nerve bundles within which a secondary meshwork of finer nerve bundles was present (Figs. 8, 9, 10); the cell bodies occurred in the nodes of the meshwork. Most ganglion neurons stain intensely for $\mathrm{AChE}$ while a few stain only moderately. Some nerve bundles arose from the secondary meshwork of the plexus to form a fine plexus branching throughout both muscle coats. The circular muscle is richly innervated with $\mathrm{AChE}$ stained nerve fibers (Fig. 9) and the longitudinal muscle layer shows a relatively moderate innervation (Fig. 10). The plexus of the esophagus was quite different from those in the stomach and intestine; the neurons showed a high AChE activity but the nerve bundles did not (Fig. 7). 


\section{Quantitative observations}

\section{Neuron counts}

The spatial density (Mean \pm SEM) of neurons is expressed in Table I. The neuronal density was $1,500 \pm 116$ neurons $/ \mathrm{cm}^{2}$ in the esophagus, $8,900 \pm 1,518$ in the stomach, $9,000 \pm 716$ in the jejunum and $13,100 \pm 2,089$ in the colon.

The difference in neuronal density between esophagus and other regions of the digestive tract was statistically significant $(p<0.05)$.

\section{Neuron size}

The results for the maximal cellular profiles (cell sizes) in the digestive tract of the Calomys callosus are shown in Table I. Neuronal sizes ranged from 45 $\mu \mathrm{m}^{2}$ to about $1,100 \mu \mathrm{m}^{2}$. The average neuronal cell size was $297 \pm 11 \mu \mathrm{m}^{2}$ in the esophagus, $290 \pm 10 \mu \mathrm{m}^{2}$ in the stomach, $179 \pm 4 \mu \mathrm{m}^{2}$ in the jejunum and $206 \pm 5$ $\mu \mathrm{m}^{2}$ in the colon. The statistical analyses indicates that the mean area of neurons in the jejunum is different from those of the esophagus, stomach and colon, while no differences were verified between the mean area of neurons in the esophagus and stomach.The majority of neurons had neuronal cell profile areas between $100 \mu \mathrm{m}^{2}$ and $300 \mu \mathrm{m}^{2}$ as shown in figure 11 .

\section{Discussion}

The histochemical method used in this paper was developed by Gabella (1969) for the study of autonomic ganglia, specially in the gut. The method stained selectively the neurons of the myenteric plexus of Calomys callosus, leaving the other cell types present in the intestinal wall unstained or only faintly stained. The results are similar to that obtained for other mammals (Schewerman and Stach, 1985; Gabella, 1987). There was no evidence that some of the myenteric neurons had not been 
stained and had remained undetected. Although there was some variation in the intensity of the reaction among the neurons of a ganglion, the reaction appeared similar in the ganglia of the four parts of the gut examined.

The nerve cells present in Calomys callosus digestive tract are agregated into ganglia, resembling those observed in other rodents (Gabella, 1987). Except for the esophagus, the neurons are gathered in long cords to fuse one another, not having a clear demarcation into ganglia. In each portion of the digestive tract the plexus have a characteristic pattern which is reproduced faithfully in different individuals and in different parts of the gut of the same animal, a clear indication of the existence of precise mechanisms regulating the morphogenesis of the plexus (Gabella, 1987). The pattern of the myenteric plexus of Calomys callosus is not different from that of other rodent species.

The spatial density of myenteric neurons varied in different parts of the digestive tract of Calomys callosus. The highest average neuronal density is found in the colon (about $13,100 \pm 2,089$ neurons per $\mathrm{cm}^{2}$ of serosal surface) a value that is substantially lower than the only other one available in the literature for the mouse (Tafuri and Almeida Campos, 1958). In the esophagus the neuronal density is about $1,500 \pm 116 / \mathrm{cm}^{2}$ and in the stomach, $8,900 \pm 1,518 / \mathrm{cm}^{2}$. There are no other counts in the literature on this species. A neuronal density similar to that of the esophagus and stomach of the Calomys callosus is found in the guinea-pig (Matsuo, 1934; Ohkubo, 1936). The value obtained for the small intestine of Calomys callosus $(9,000 \pm 711$ neurons $/ \mathrm{cm}^{2}$ ) is much lower that cited for the mouse by Tafuri and Almeida Campos (1958) but similar to that of 10,600 neurons $/ \mathrm{cm}^{2}$ published by Gabella (1987).

The size of myenteric neurons in mice has been investigated in a previous paper by Gabella (1987) and Bor-Seng-Shu (1994). In Calomys callosus, the myenteric perikarya cover a wide range of sizes and this is true for all four portions of the gut. The present work showed that the range of sizes is wider in the Calomys 
callosus than in the mice. A population of small neurons is present in all four portions of its digestive tract, whereas the largest myenteric neurons are larger in the stomach than in the esophagus, and are larger in the esophagus than in the jejunum and colon. It is not clear at present whether the variation in size within the population of myenteric neurons reflects different functional specialization, or whether they reflect differences in the extent of their territory of innervation (Chiang and Gabella, 1986).

Using the acetylcholine method, a strong AChE staining could be observed within myenteric plexus perikarya of the Calomys callosus gastrointestinal tract. The majority of the ganglion neurons stain intensely for AChE. It was also possible to see nerve fibers stained for AChE in the longitudinal and circular smooth muscle layers. This finding is in agreement to that of the gastrointestinal tract of several mammalian species (Jacobowitz, 1965; Gunn, 1968; Wolter, 1985; Bor-Seng-Shu, 1994). The presence of AChE-activity suggests the cholinergic nature of these neurons although $\mathrm{AChE}$-positive neurons need not necessarily be cholinergic since adrenergic and non cholinergic neurons might display AChE positivity (Eranko et al., 1970; Levey et al., 1983; Seelig et al., 1984). In fact, in the brain it was demonstrated non-cholinergic functions of $\mathrm{AChE}$ and $\mathrm{AChE}$ was present in DOPAminergic nigrostriatal neurons (Greenfield, 1985). Furthermore, Anglade et al. (1988) showed neuronal AChE activity and immunoreactive peptide varicosities simultaneously in the myenteric plexus.

The results of the present study show that the myenteric plexus of the Calomys callosus digestive tract contains a large number of nerve cells, which have different sizes and $\mathrm{AChE}$ activities. This results and the distribution of the cholinesterase-positive fibers in the myenteric plexus of Calomys callosus conformed to the general pattern of gastrointestinal innervation demonstrated for mammals mainly for mice. 
References

Anglade P, Michel C, Ozaki T, Tsuji S, Vignon X \& Yanaihara N (1988). Simultaneous localization of acetylcholinesterase activity and met-enkephalin, vasoactive intestinal peptide and substance P immunoreactivity in the rat myenteric plexus. Histochem. J., 20: 464-467.

Bor-Seng-Shu E, Chadi G, Bor-Jiun-Shu F, Ferraz-de-Carvalho CA \& De-Souza RR (1994). Myenteric neurons of the mouse small intestine. Morphometry and acetylcholinesterase activity. Braz. J. Med. Biol. Res., 27: 101-108.

Borges MM, Curi PR \& Kloetzel JC (1992). Modulation of parasitemia and antibody response to Trypanosoma cruzi by cyclophosphamide in Calomys callosus (Rodentia, Cricetidae). Rev. Inst. Med. Trop. São Paulo, 34: 1-8.

Chiang C \& Gabella G (1986). Quantitative study of the ganglion neurons of the mouse trachea. Cell Tissue Res., 246: 243-252.

Eranko O, Rachardt L, Eranko L \& Cunninghan A (1970). Light and electron microscopic histochemical observations on cholinesterase containing sympathetic nerve fibers in the pineal body of the rat. Histochemical Journal, 2: 479-489.

Gabella G (1969). Detection of nerve cells by a histochemical technique. Experientia, 25: 218-219.

Gabella G (1987). The number of neurons in the small intestine of mice, guinea-pig and sheep. Neuroscience, 22: 737-752.

Greenfield SA (1985). Acetylcholinesterase release from dendrites. Neuroscience Letters, 22 (suppl.): S3.

Gunn M (1968). Histological and histochemical observations on the myenteric and submucous plexuses of mammals. J. Anat., 2: 223-239. 
Jacobowitz D (1965). Histochemical studies of the autonomic innervation of the gut. $J$. Pharmacol. Exp. Therap., 149: 358-364.

Karnowsky MJ \& L. Roots L (1964). A "direct-coloring" thiocholine method for cholinesterases. J. Histochem. Cytochem., 12: 219-221.

Levey AI, B.H. Wainer BH, Mufson EJ \& Mesulan MM (1983). Co-localization of acetylcholinesterase and choline acetyltransferase in the rat cerebrum. Neuroscience, 9: 9-22.

Matsuo H (1934). A contribution on Anatomy of Auerbach's plexus. Spn. J. Med. Sci. Anat., 4: 417-428.

Ohkubo K (1936). Studien über das intramurale Nervensystem des Verdaungskanals. II. Die plexus myentericus und Plexus subserosus des Meerschweichens. Jpn. J. Med. Sci., 6: 21-37.

Ribeiro RD (1973). New reservoir of Trypanosoma cruzi. Rev. Bras. Biol., 33: 429-537.

Seelig LL, Doody P, Brainards L, Gidda JS \& Goyal RK (1984). Acetylcholinesterase and choline acetyltransferase staining of neurons in opossum oesophagus. Anat. Rec., 209: 130-135.

Schewerman DW \& Stach W (1985). A simultaneous demonstration of particular enteric neuronal cell types with the NADH: Nitro BT-dehydrogenase reaction and of nerve fibers containing enkephalin-like immunoreactivity in the myenteric plexus of the porcine small intestine. Histochemistry, 82: 269-273.

Tafuri WL \& De Almeida Campos F (1958). Der Auerbach Plexus bei der Maus. Z. Naturforsch., 13 B: B816-819.

Wolter HJ (1985). Topography of cholinergic perikarya and nerve fibers as well as cholinergic vesicles in the rat duodenum. Brain Res., 339: 337-341.

Zar JH (1984). Biostatistical analysis. Prentice-Hall, N. Jersey. 


\section{Figures}

Table 1 - Number and size of myenteric neurons of the digestive tract of Calomys callosus. Data are reported as mean $\pm \mathrm{SEM}(\mathrm{P}<0.05)$.

Figures 1 - 6 - Histochemically stained myenteric ganglia from Calomys callosus. 1-3- Esophageal ganglia. Note the striated musculature of esophagus. 4Large ganglion from the stomach. Note the variation in neuronal size. 5- Large ganglion from jejunum showing a densely packed cluster of neurons. 6- Ganglion from the sigmoid colon. Note the variation in the intensity of the reaction between the neurons. Calibration bars: $20 \mu \mathrm{m}$.

Figures $7-10$ - Stretch preparation from the muscle layer of the esophagus (7), stomach (8), jejunum (9) and colon (10) showing the myenteric plexus. Cholinesterase method . 7- Two neurons intensely stained. 8-10- The plexus consists of a primary meshwork of thick nerve bundles (arrows) and a secondary meshwork of finer bundles (arrowheads). In the primary meshwork, the nerve cell bodies occur mainly at the nodes of the plexus. Note the variable intensity of staining of the nerve cells. Calibration bars: $40 \mu \mathrm{m}$

Figure 11- Distribution of the nerve cell profile areas of myenteric neurons in different regions of the gut of Calomys callosus. Most of the neurons had nerve cell profile areas between $100 \mu \mathrm{m}$ and $300 \mu \mathrm{m}$. $\mathrm{N}=$ 300 cells measured for each region. 


\begin{tabular}{|l|c|c|}
\cline { 2 - 3 } \multicolumn{1}{c|}{} & $\begin{array}{c}\text { Neuron Density } \\
\left(\mathrm{per} \mathrm{cm}^{2}\right)\end{array}$ & $\begin{array}{c}\text { Neuron cell profile area } \\
\left(\mu \mathrm{m}^{2}\right)\end{array}$ \\
\hline Esophagus & $1,500 \pm 116$ & $297 \pm 11$ \\
\hline Stomach & $8,900 \pm 1,518$ & $290 \pm 10$ \\
\hline Jejunum & $9,000 \pm 711$ & $179 \pm 4$ \\
\hline Colon & $13,100 \pm 2,089$ & $206 \pm 5$ \\
\hline
\end{tabular}



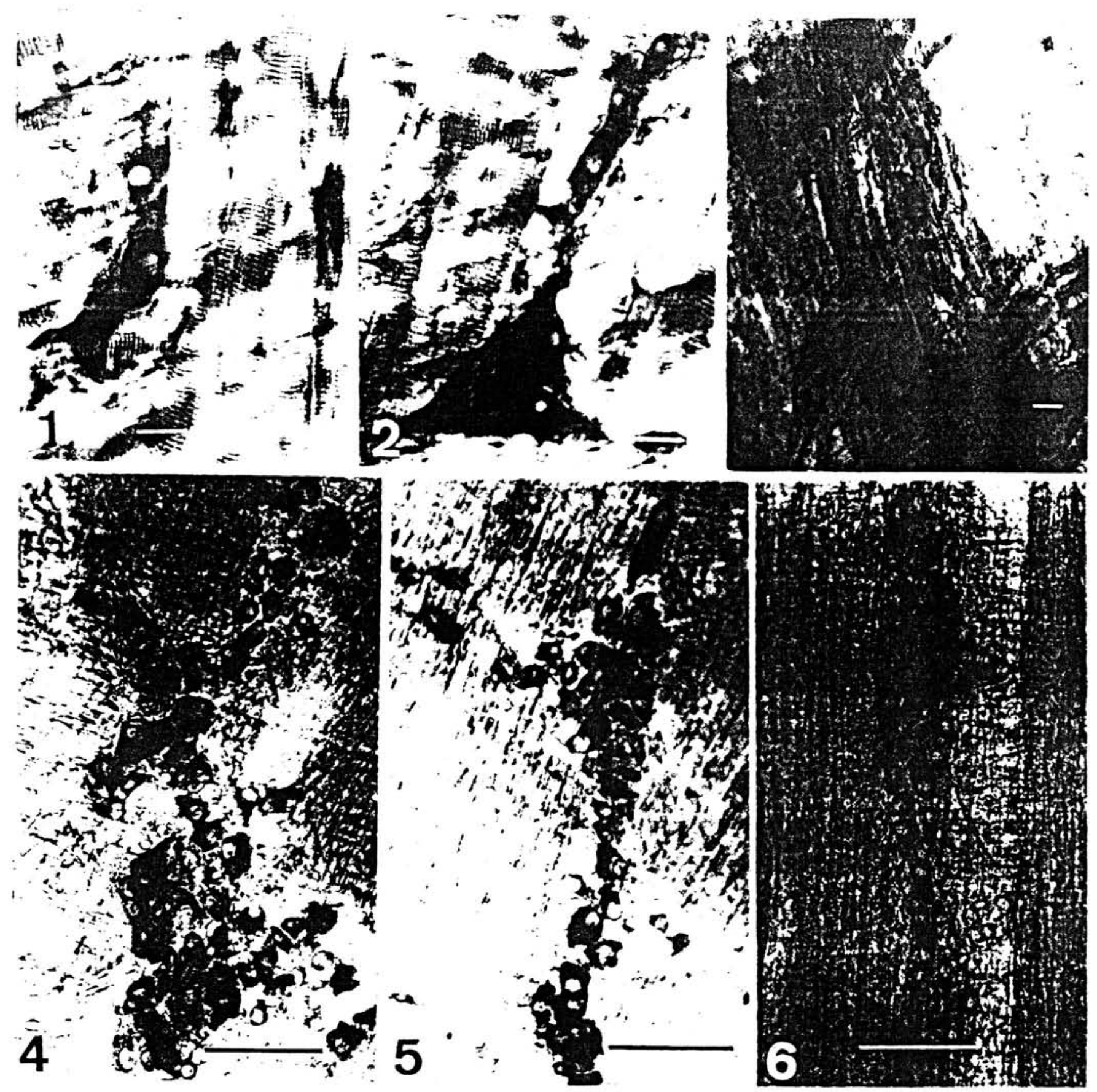

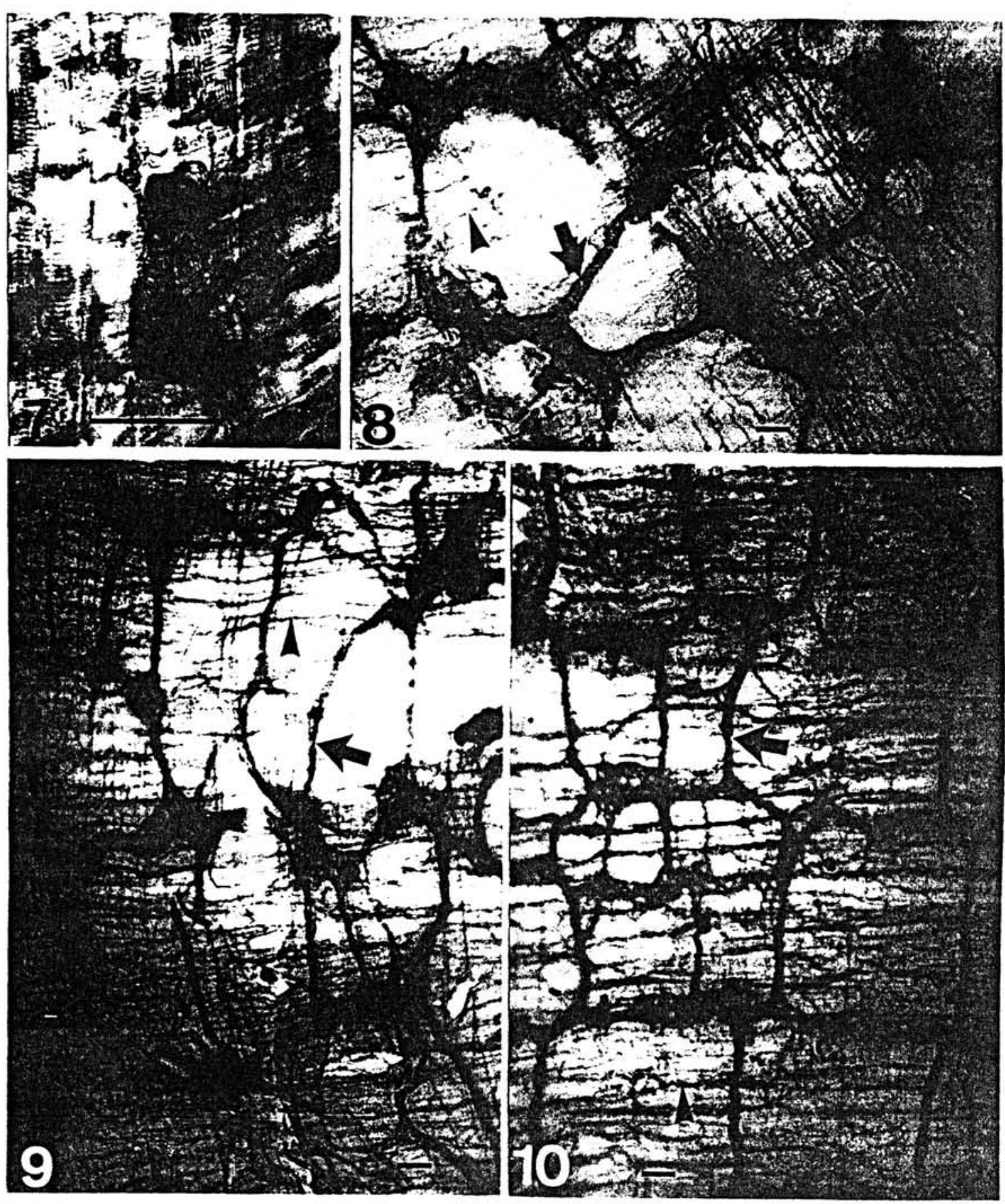

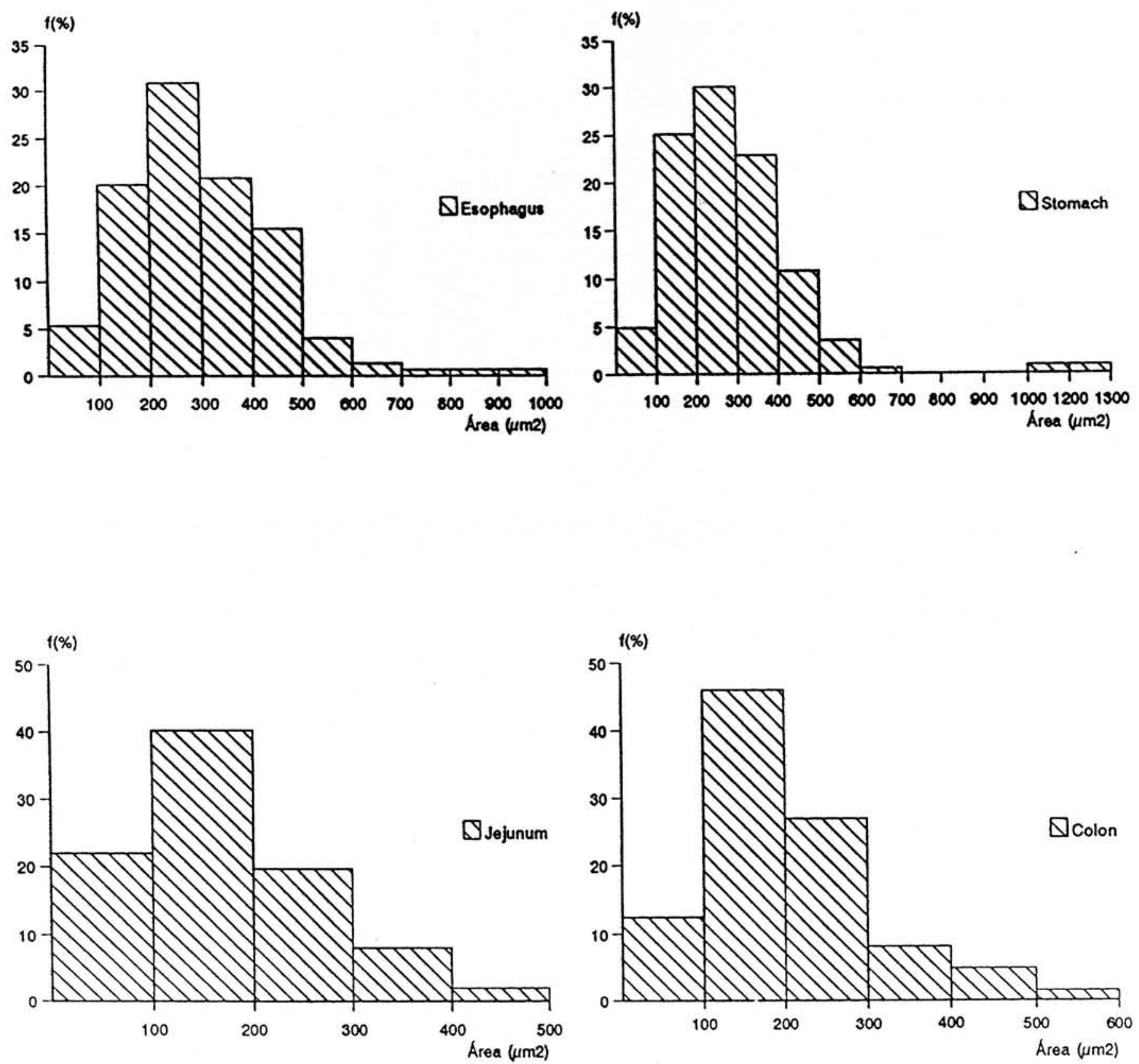
TRABALHO IV 


\title{
ESTUDO MORFOQUANTITATIVO DO PLEXO MIENTÉRICO DO INTESTINO DELGADO DE RATOS DESNUTRIDOS.
}

\author{
(EDSON AP. LIBERTI)
}

\section{PROJETO DE PESQUISA APROVADO PELO CNPq em janeiro de 1996 - processo $\mathrm{N}^{\circ} 306130 / 88-2$}

\section{1- INTRODUÇÃO}

Sabe-se que o crescimento de qualquer órgão ou tecido, principalmente na fase de intensa proliferação celular, onde os tecidos encontram-se muito sensíveis a agressões ambientais, é alterado por fatores externos que atuam durante a gestação, sendo que dentre eles, a desnutrição é aquele que, dependendo do momento em que ocorre, sua duração e intensidade, pode causar efeitos nocivos, principalmente em órgãos e tecidos que estejam em fase de desenvolvimento acelerado.

As alterações nos filhotes de várias espécies animais podem ser verificadas em diversas partes do corpo, podendo-se citar como exemplos a pele, que mostra espessura reduzida e queratinização menos acentuada (LANSDOWN, 1978) e ausência das camadas granulosa e córnea (NAEYE, 1965); os ossos, de tamanho reduzido (SHRADER \& ZEMAN, 1973), desenvolvimento atrasado em relação à idade gestacional (ADAMS, 1971; SHRADER \& ZEMAN, 1973); os rins, bastante pequenos, com peso correspondendo à metade do observado em animais controle, córtex renal delgado, pequeno número de glomérulos e relativamente poucos túbulos coletores na medula (ZEMAN, 1967, 1968, 1970); n pâncreas, com alterações em sua estrutura exócrina, diminuindo a quantidade de 
ácinos e o tamanho das células acinares, e a mucosa do intestino delgado apresentando uma redução na quantidade de vilosidades (SHRADER \& ZEMAN, 1969). Por outro lado, certos órgão podem ter seu tamanho reduzido sem contudo apresentarem alterações marcantes em sua estrutura, como é o caso dos pulmões (WIGGLESWORTH, 1964); do baço (ZEMAN, 1967); do coração (WIGGLESWORTH, 1964; NAEYE, 1965); das suprarenais (ZEMAN, 1967); da tireóide e do figado (SHRADER \& ZEMAN, 1969).

No tecido nervoso, seus efeitos são descritos mais especificamente no Sistema Nervoso Central de várias espécies animais (CHASE et al., 1971; CRAGG, 1972; DEO et al., 1978; ZEMAN, 1967). Dentre esses efeitos pode-se destacar a perda de terminações nervosas de axônios no córtex (EAYRS \& HORN, 1955)e a redução do número de neurônios multipolares no córtex cerebral e na medula espinal (SHRADER \& ZEMAN, 1969) bem como da espessura do córtex cerebral (ZAMENHOF et al., 1971; CLARK et al., 1973; YAMANO et al., 1980).

No Sistema Nervoso Autônomo, a redução de $27 \%$ no número de neurônios do plexo mientérico foi determinada por SANTER \& CONBOY (1990), no intestino delgado de ratos adultos cujas mães sofreram restrição na dieta durante as duas últimas semanas de gestação. No gânglio cervical superior de ratos submetidos a uma dieta hipoprotéica por um período de trinta dias, ocorre um decréscimo significativo no conteúdo protéico dos gânglios, e principalmente nas enzimas sintetizadoras dos neuro-transmissores (GAETANI et al., 1977). A redução do tamanho do neurônio e na quantidade de noradrenalina do gânglio mesentérico superior de filhotes cujas mães foram desnutridas foi relatada por CONBOY et al., 1987. 


\section{2- OBJETIVOS}

Considerando-se que os plexos entéricos, longe de serem estruturas estáticas, são na realidade estruturas adaptativas que em alguns aspectos não estão ainda bem estudados, e que a desnutrição pode ser um fator que determine uma adaptação desses plexos em algum estágio da vida de um animal, pretendemos na presente pesquisa, com o auxilio da microscopia de luz e eletrônica de transmissão, verificar no plexo mientérico do intestino delgado de ratos jovens submetidos à desnutrição:

a- A densidade de neurônios ganglionares (número de neurônios/área);

b- A morfologia e o tamanho dos neurônios ganglionares;

c- As características morfológicas das fibras do sistema elástico e colágenas dos gânglios;

d- A morfologia das malhas interganglionares;

e- A ultra-estrutura dos neurônios e dos componentes ganglionares.

Entendemos que os resultados obtidos poderão acrescentar dados sobre o modo de reação dos neurônios entéricos quando submetidos a diferentes agentes modificadores da sua fisiologia normal. 


\section{3- MATERIAIS E MÉTODOS}

Serão utilizados ratos Albimus wistar machos e fêmeas, acasalados durante um período de dez dias, findo o qual, as fêmeas serão separadas em gaiolas individuais. Esse período foi determinado para que não ocorra uma grande diferença no tempo decorrido entre o início do acasalamento e a cópula para cada fêmea, evitando-se assim uma disparidade no processo de desnutrição da mãe.

As fềmeas serão então divididas respectivamente nos grupos nutrido $(\mathbf{N})$ e desnutrido (D), de acordo com as dietas controle e hipoprotéica, ambas Ad libitum de água, estabelecidas pelo Laboratório de Nutrição do Departamento de Fisiologia do ICB da USP (DE ANGELIS et al., 1988) e expressas a seguir:

\section{Componentes dieta controle dieta hipoprotéica}

$\begin{array}{lcc}\text { Caseina } & \mathbf{2 0 \%} & 5 \% \\ \text { Sais } & \mathbf{4 \%} & \mathbf{4 \%} \\ \text { Vitaminas } & 5 \% & 5 \% \\ \text { Óleo } & \mathbf{8 \%} & \mathbf{8 \%} \\ \text { Açúcar } & \mathbf{5 \%} & \mathbf{5 \%} \\ \text { Amido } & >100 & >100\end{array}$

As dietas serão mantidas até que os filhotes atinjam 21 dias de vida extrauterina, época determinada para o desmame. Como as ninhadas podem apresentar de 4 a 12 filhotes, estabeleceu-se como número mínimo 6 e como número máximo 8 animais por ninhada, sendo desprezadas as ninhadas com menos de 6 filhotes, ninhadas cujas mães comeram os filhotes e ninhadas com excedente a 8 filhotes. Aos 21 dias de vida os filhotes serão pesados e identificados através de numeração de 1 a 6 na cauda, sendo dois de cada ninhada escolhidos aleatoriamente por sorteio, a fim de serem submetidos às diversas técnicas. 
3.A- Processamento para estudo quantitativo neuronal (densidade, área do perfil celular)

Com o objetivo de demonstrar os neurônios ganglionares e a distribuição dos mesmos nos preparados totais de membrana, serão utilizados 6 animais de cada um dos grupos (N, D) que serão sacrificados por overdose de éter e terão a parede abdominal aberta e o intestino delgado removido desde o piloro até a válvula íleo-cecal. Em seguida, a fim de tornar suas paredes levemente distendidas, será injetada na luz da víscera, com o auxílio de uma bomba de perfusão à qual foi adaptado um esfignomanômetro para manutenção da pressão em torno de $10 \mathrm{mmHg}$ quantidade suficiente de solução de Krebs (GABELLA, 1987b)

Para se detectar os neurônios ganglionares, os intestinos serão ligados nas extremidades com fio de algodão e submetidos à técnica do NADH (GABELLA, 1971) que consiste nas seguintes etapas:

- Imersão no meio de coloração (solução de $0,5 \mathrm{mg} / \mathrm{ml}$ de Nitro-Blue Tetrazolium (SIGMA) em água destilada; 25 partes de tampão fosfato de sódio $(0,1$ $\mathrm{M} \mathrm{pH} \mathrm{7,3)} \mathrm{e} 50$ partes de água; $0,5 \mathrm{mg} / \mathrm{ml}$ de NADH na forma reduzida (SIGMA);

- Pré-incubação por 1 a 3 minutos (solução de 0,3\% de Triton X100) para facilitar a penetração do meio;

- Lavagem em solução de Krebs;

- Imersão por 45 a 60 minutos no meio de coloração.

Após a coloração, cinco segmentos de aproximadamente $3 \mathrm{~cm}$, ligados nas extremidades com fio de algodão, serão retirados ao longo do intestino delgado de cada animal, sendo um proximal (após o piloro); um distal (anterior à válvula íleo cecal); um médio (equidistante aos segmentos proximal e distal); um intermédio proximal (entre os segmentos proximal e médio) e um intermédio distal (entre os segmentos médio e distal). 
As peças serão então abertas em seu longo eixo sendo assim mantidas entre duas lâminas de vidro a fim de terem suas áreas decalcadas em papel vegetal.

Proceder-se-á então à fixação em solução de $10 \%$ de formalina por um período de 1 a 7 dias findo o qual as mesmas terão novamente sua área decalcada a fi de se calcular o índice de retração. Em seguida, as camadas mucosa è submucosa serão dissecadas sob microscopio cirúrgico para se destacar o plexo mientérico.

A densidade neuronal bem como a área de 100 neurônios por segmento, serão determinadas com o auxílio de equipamento de aquisição de imagem computadorizada para estudo de morfometria.

\section{B-Para evidenciar reação à acetilcolinesterase (AChE)}

Três animais de cada grupo $(\mathbf{C}, \mathbf{D})$ serão utilizados para este propósito. Após perfusão com solução salina e a seguir solução de paraformaldeído a $2 \%$ através do ventrículo esquerdo, serão obtidos segmentos do intestino delgado conforme descrito no ítem 3.A. As membranas serão mantidas em solução fixadora (paraformaldeído a $2 \%$ ) por um período de 12 horas, após o qual serão colocadas em solução d lavagem constituída por $60 \mathrm{~g}$ de sacarose, $200 \mathrm{ml}$ de água destilada e $2 \mathrm{~g}$ de goma arábica em pó, onde permanecerão por cerca de 24 horas. A seguir, as membranas serão imersas em solução de Isoompa por 20 minutos de depois em uma solução contendo $5 \mathrm{mg}$ de acetilcolina, $6,5 \mathrm{ml}$ de tampão fosfato $0,1 \mathrm{M}(\mathrm{pH} \mathrm{6,),0,5 \textrm {ml }}$ de citrato de sódio, $1 \mathrm{ml}$ de sulfato de cobre $(30 \mathrm{mM}), 1 \mathrm{ml}$ de água destilada e $1 \mathrm{ml}$ de ferricianeto de potássio $(5 \mathrm{mM})$ por um período de 2 a 12 horas, em estufa a $37{ }^{\circ} \mathrm{C}$ (KARNOVSKY \& ROOTS, 1964).

Após esse período, as membranas serão desidratadas em duas passagens de 3 minutos em álcool absoluto, diafanizadas em duas passagens de 3 minutos em xilol e montadas entre lâmina e lamínula. 


\section{C- Para estudo quantitativo das fibras colágenas e do sistema} elástico

Para esse estudo serão utilizados anéis obtidos das diversas regiões do intestino delgado de 3 animais do grupo experimental (D) e de 3 animais do grupo controle (N).

Para as fibras colágenas, os anéis serão fixados em solução de Bouin e submetidos a cortes histológicos transversais e tangenciais à parede da víscera de $5 \mu \mathrm{m}$ de espessura, que serão corados pelos métodos de Azan, e Picro sirius de acordo com JUNQUEIRA et al. (1979), estes últimos examinados sob luz polarizada.

Para as fibras do sistema elástico (elásticas, elaunínicas e oxitalânicas), os cortes obtidos como descrito anteriormente, serão corados alternadamente pelos métodos da hematoxilina férrica (VERHÖEFF, 1908), e resorcina-fucsina (WEIGERT, 1898) corados com e sem prévia passagem pela oxona, de acordo com GREENSPAN (1946); FULLMER (1959); PEARSE (1968) E SAMPAIO \& COTTA-PEREIRA (1971). O método da hematoxilina férrica evidencia apenas fibras elásticas "maduras"; o método da resorcina-fucsina, quando os cortes não são previamente tratados pela oxona, mostra fibras elásticas e elaunínicas e quando se segue a tratamento prévio por aquela substância, evidencia também fibras oxitalânicas.

\section{D-Microscopia Eletrônica de Transmissão}

Serão utilizados 3 animais do grupo controle e 3 animais do grupo experimental. Após anestesia intraperitoneal, os mesmos tiveram aberta a parede abdominal, sendo em seguida injetada na luz da víscera, uma solução fixadora com $5 \%$ de glutaraldeído em tampão cacodilato de sódio, pH 7.4.

As peças serão imersas na solução fixadora durante 24 horas a temperatura ambiente, e durante esse tempo, cada uma será cortada em três segmentos de $1 \mathrm{~cm}$ correspondendo às regiões estabelecidas no ítem $\mathbf{A}$, sendo então 
cada segmento seccionado em vários anéis de $2 \mathrm{~mm}$ de espessura. Após a fixação, os mesmos serão lavados em tampão e pós-fixados em tetróxido de Ósmio a $2 \%$ durante 1 hora.

Após tratamento com solução aquosa saturada de acetato de uranila a $1 \%$ durante duas horas, as peças serão desidratadas em uma série crescente de álcoois e incluídas em araldite.

Os cortes ultra-finos serão corados com uma solução de $1 \%$ de acetato de uranila em $70 \%$ de etanol e citrato de chumbo, e examinados ao microscópio eletrônico de transmissão. 


\section{4- RESULTADOS PRÉVIOS}

\section{Aspectos qualitativos}

A reação descrita no item 3.A (Estudo quantitativo neuronal), permitiu evidenciar os neurônios do plexo mientérico do intestino delgado em a.ibos os grupos.

Nos animais do grupo controle, (Nutridos) a visão geral é a de que os gânglios são estruturas alongadas, paralelas entre sí, e cujos limites entre um gânglio e outro não são precisos (Fig. 1a). Nos animais do grupo experimental (Desnutridos), observa-se células esparsas, raramente aglomeradas, demonstrando um padrão bastante diferente do observado para o grupo controle (Fig. 1b).

Os gânglios dos animais do grupo controle apresentam neurônios de váriso formatos, sendo alguns com citoplasma bem evidenciado e outors com citoplasma pouco corado, provavelmente devido ao estágio de maturação em que se encontram (Fig. 2a); por outro lado, são poucos os neurônios do grupo desnutrido que apresentam citoplasma bem evidenciado (Fig. 2b).

Em maior aumento, pode-se constatar que, além de serem realmente maiores os neurônios presentes nos gânglios dos animais nutridos, o citoplasma de algumas células se coram intensamente, entremeados por outras cujo citoplasma se cora pouco (Fig. 3.a). Nos gânglios dos animais desnutridos, os neurônios que se evidenciam apresentam citoplasma fracamente corado, sendo que a maior parte possui bem evidente somente o núcleo, de forma prevalentemente arredondada (Fig. 3b).

\section{Aspectos quantitativos}

Foram medidos preliminarmente 250 neurônios de 3 animais do grupo controle 250 neurônios de 3 animais do grupo desnutrido, escolhidos ao acaso, a fim de se verificar as possiveis diferenças na distribuição dos corpos celulares de acordo com o tamanho entre os grupos. Como pode ser observado na Figura 4, nota-se que a distribuição dos corpos 
celulares é bem diferente entre os grupos, demonstrando claramente uma grande quantidade de neurônios concentrados entre os intervalos de $0-100 \mu \mathrm{m}^{2}$ e $101-200 \mu \mathrm{m}^{2}$, enquanto que a distribuição dos neurônios nos animais nutridos é mais uniforme, verificando-se aproximadamente $40 \%$ dos corpos neuronais com área entre $201-300 \mu \mathrm{m}^{2}$.

Uma análise estatística desses resultados parciais (Tabela 1) demonstra que há diferenças significativas entre os grupos quanto à distribuição dos neurônios de acordo com as áreas. As médias das áreas, ou seja, $246,44 \mu \mathrm{m}^{2}$ para os neurônios do grupo nutrido e $119,56 \mu \mathrm{m}^{2}$ para os neurônios do grupo desnutrido, podem também ser consideradas diferentes. 


\section{LEGENDAS}

Figura 1- Visão geral, em pequeno aumento, dos gânglios do plexo mientérico do intestino delgado de ratos Nutridos (a) e desnutridos (b). Notar o aspecto de colunas alongadas assumido pelos gânglios em a, e a distribuição esparsa dos neurônios em b. (NADH. 107X)

Figura 2- a- Neurônios com citoplasma bem evidenciado, e apresentando diversas formas, presentes nos gânglios dos animais nutridos. Observa-se alguns neurônios pouco corados, mas com núcleo arredondado bem evidente (setas); bAspecto de alguns poucos neurônios corados que constituem o plexo mientérico dos animais desnutridos. Nota-se ainda, neurônios com citoplasma muito pouco corado, mas com núcleo evidenciado (setas) (NADH. 274X)

Figura 3- a- Em maior aumento, pode-se constatar nos gânglios do plexo dos animais nutridos, neurônios de tamanho grande, com citoplasma fortemente corado, entremeados por neurônios com núcleo arredondado evidente mas pouco corados (seta); b- Neurônios pouco corados do plexo dos animais desnutridos e diversos neurônios pouco corados (setas), predominantes nesse grupo (NADH. $1100 \mathrm{X})$

Figura 4- Distribuição das áreas dos neurônios do plexo mientérico de animais nutridos e desnutridos.

Tabela 1- Análise estatística das frequências observada (desnutrido) e esperada (nutrido) para as áreas dos neurônios. 

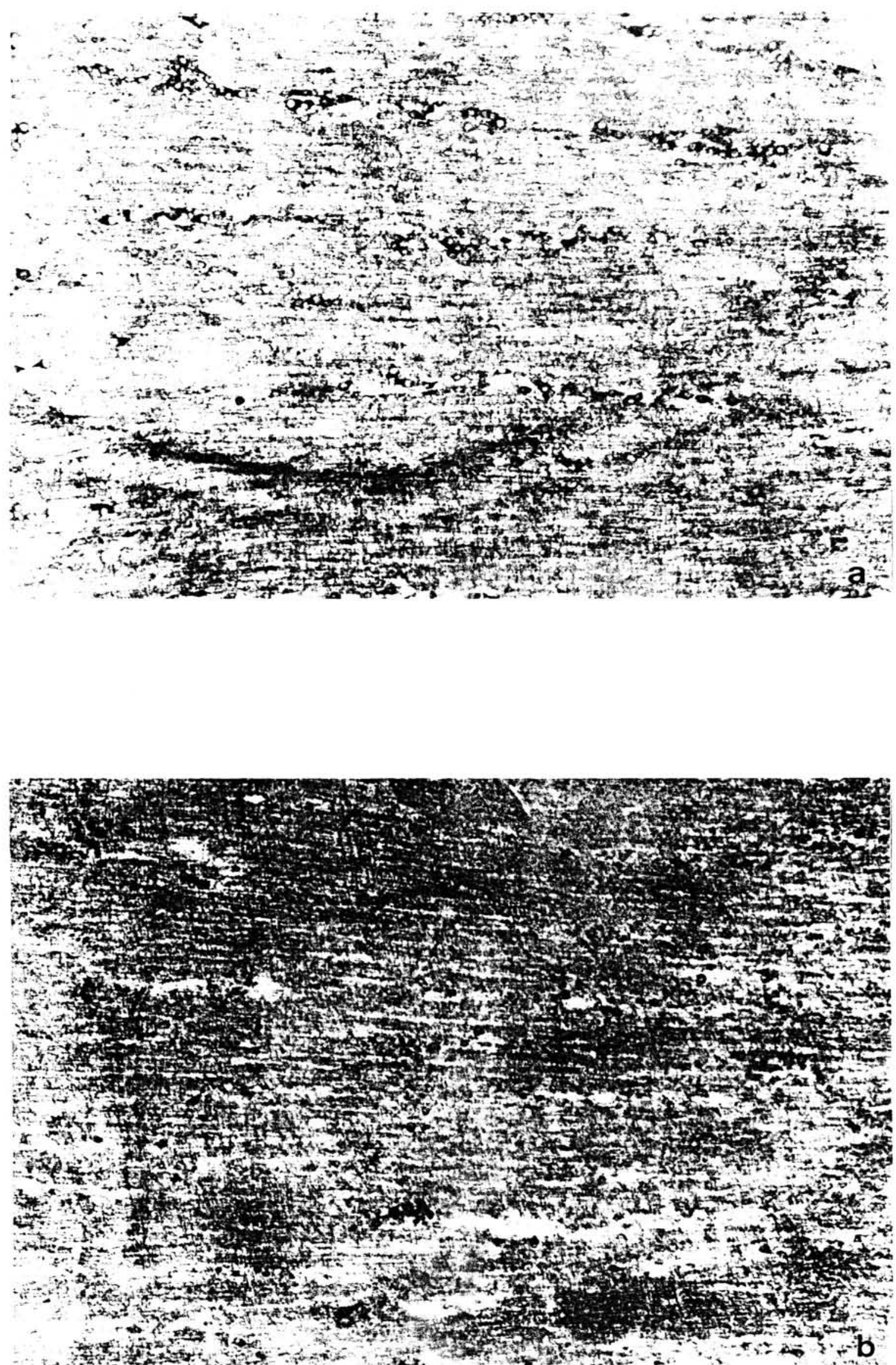


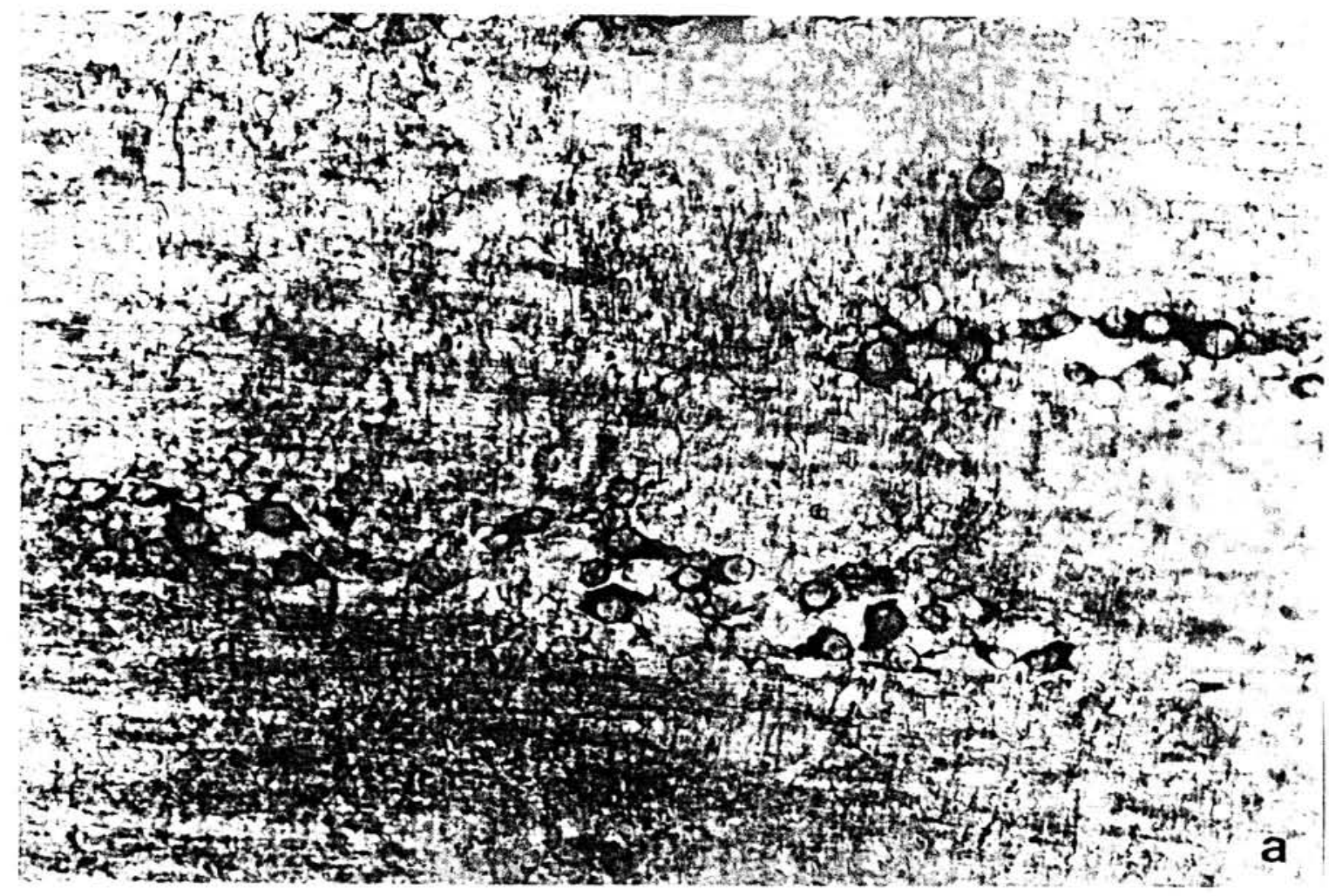

(n)

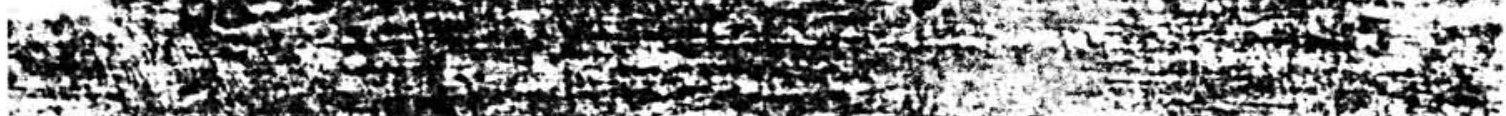

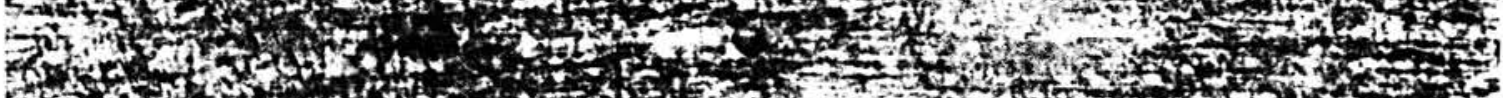

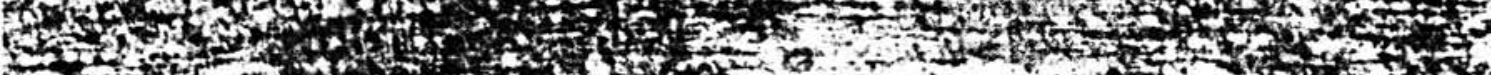

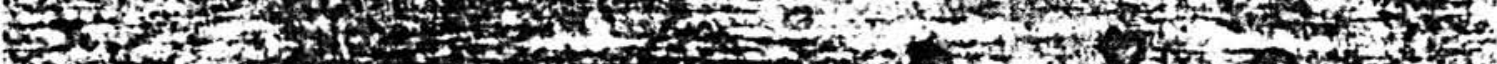
3.t.

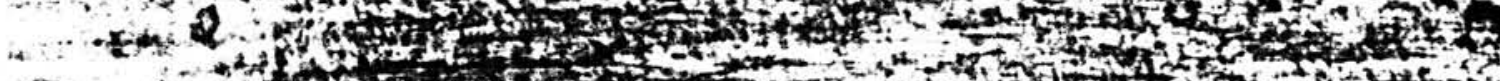

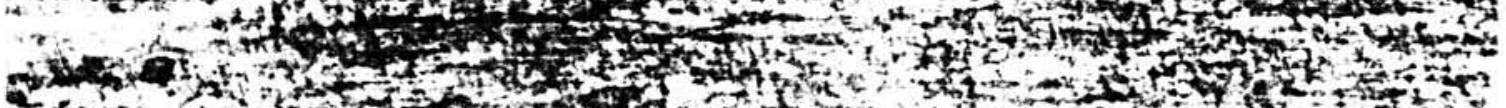

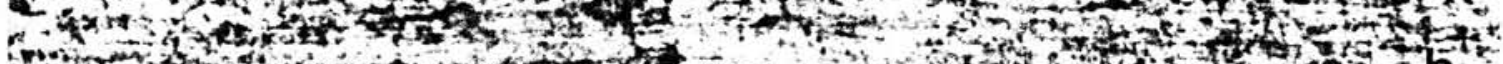

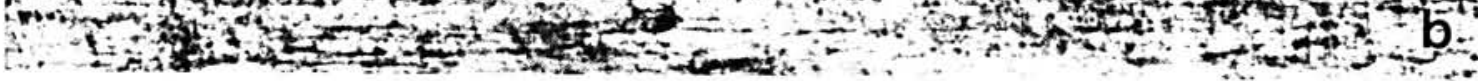




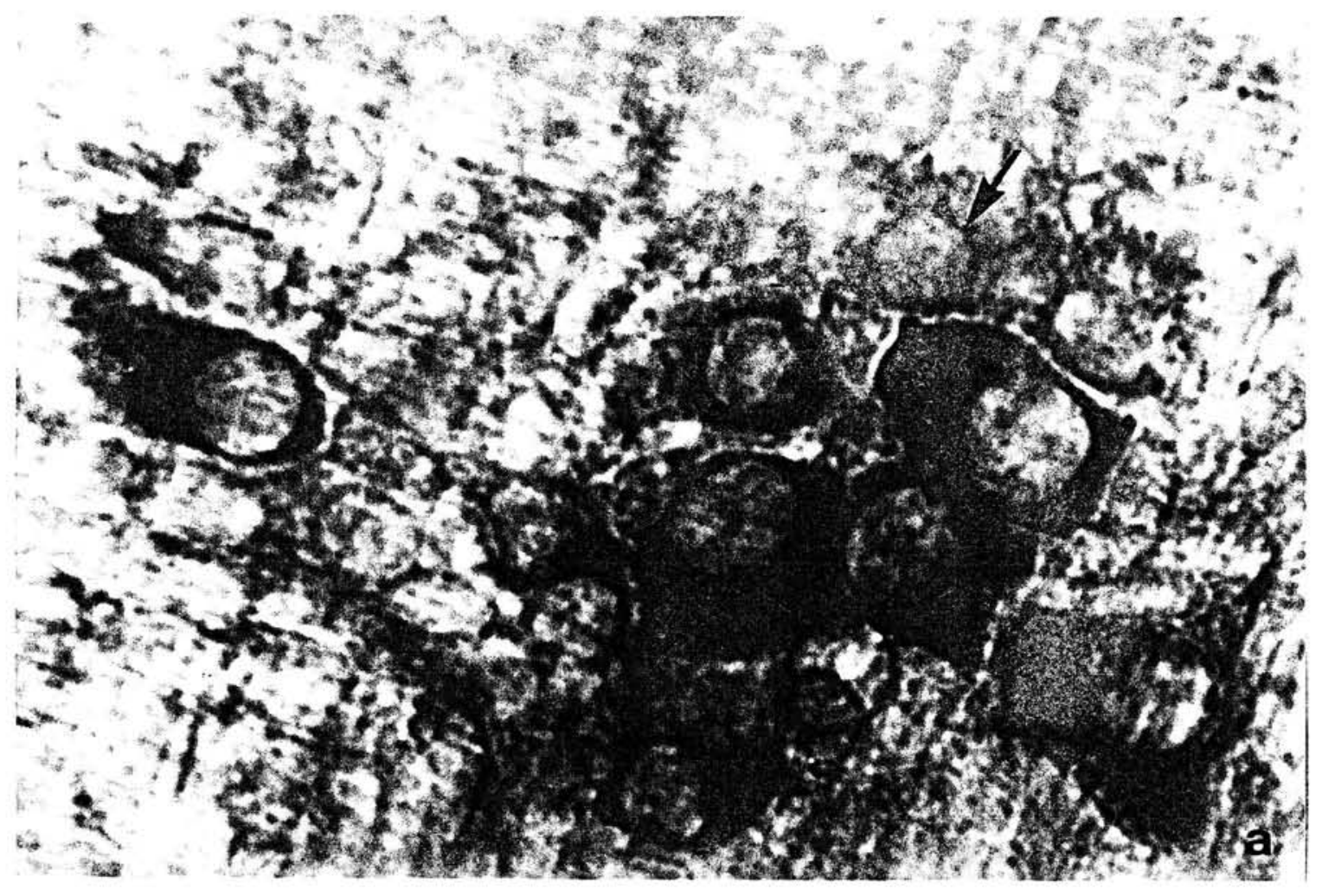

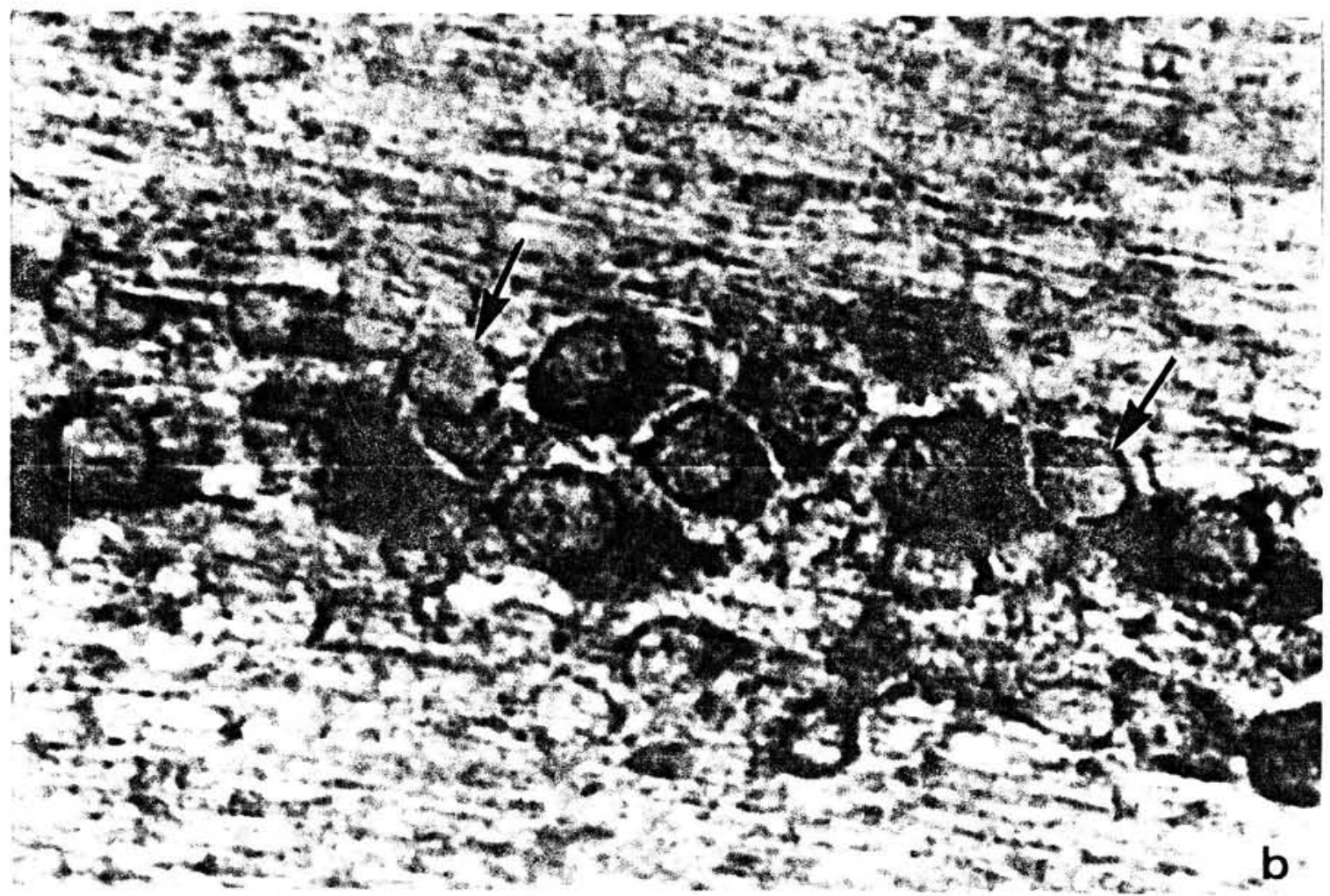




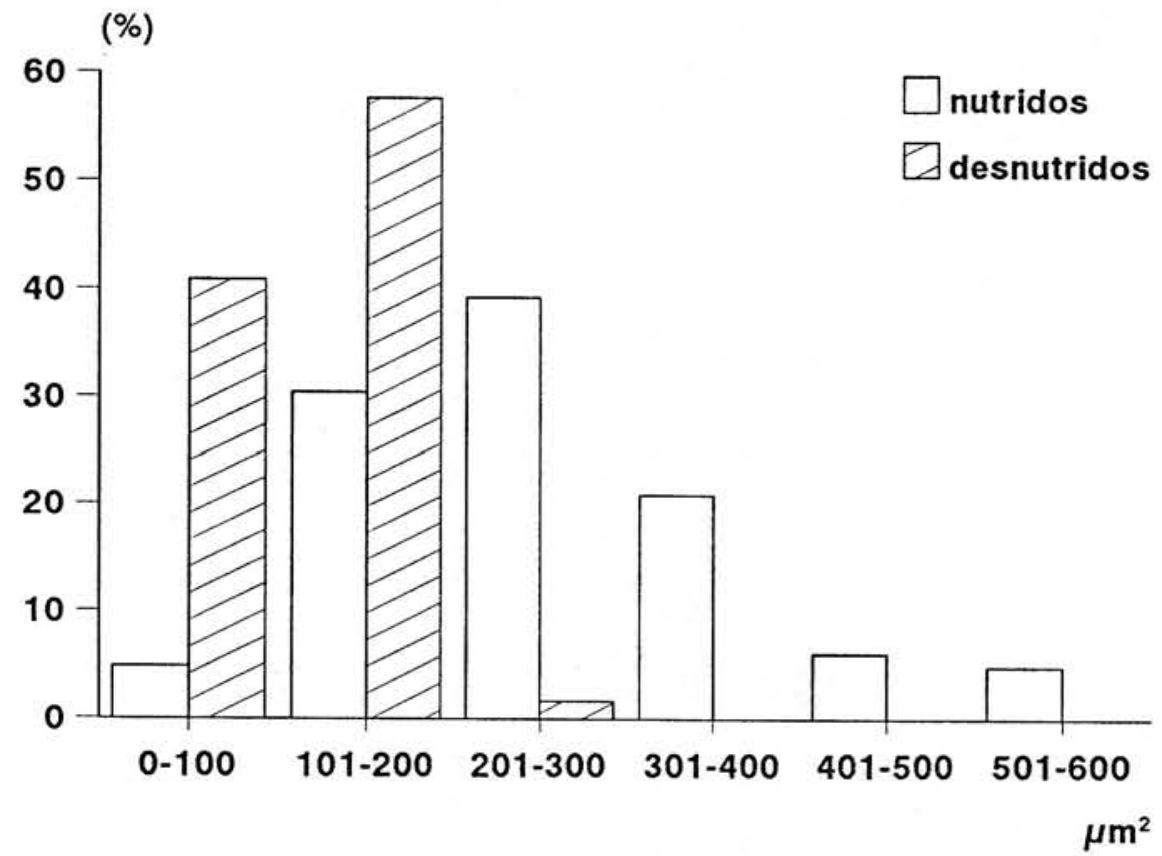


Chi-Square Goodness-of-Fit Test

\begin{tabular}{ccr}
$\begin{array}{c}\text { Observed } \\
\text { Frequency }\end{array}$ & $\begin{array}{c}\text { Expected } \\
\text { Frequency }\end{array}$ & Chi-Square \\
\hline 0 & 5.0 & 5.000 \\
0 & 7.0 & 7.000 \\
0 & 3.0 & 3.000 \\
0 & 2.0 & 2.000 \\
0 & 4.0 & 4.000 \\
0 & 4.0 & 4.000 \\
0 & 2.0 & 2.000 \\
0 & 2.0 & 2.000 \\
0 & 1.0 & 1.000 \\
0 & 1.0 & 1.000 \\
0 & 1.0 & 1.000 \\
0 & 1.0 & 1.000 \\
0 & 1.0 & 1.000 \\
\hline
\end{tabular}

Chi-square $=1348.2$ with 40 d.f.

Sig. Tevel $=0$

Chi-Square Goodness-of-Fit Test

$\begin{array}{ccc}\begin{array}{c}\text { Observed } \\ \text { Frequency }\end{array} & \begin{array}{c}\text { Expected } \\ \text { Frequency }\end{array} & \text { Chi-Square } \\ 0 & 2.0 & 2.000 \\ 0 & 1.0 & 1.000\end{array}$

Chi-square $=1348.2$ with $40 \mathrm{~d} . \mathrm{f}$.

Sig. level $=0$ 


\section{5- BIBLIOGRAFIA}

ADAMS, P.H. Intra-uterine growth retardation in the pig II. development of the skeleton. Biol. Neonate, 19: 341-353, 1971.

BAKER, D.M. \& SANTER, R.M. A quantitative study of the effects of age on the noradrenergic innervation of Auerbach's plexus in the rat. Mech. Ageing Dev., 42: 147-158, 1988.

BALUK, P. \& GABELLA, G. Fine structure of the autonomic ganglia of the mouse pulmonary vein. J. Neurocytol.., 16: 169-184, 1987.

BALUK, P. \& GABELLA, G. Innervation of the guinea-pig trachea: A quantitative morphological study of intrinsic neurons and extrinsic nerves. J. Comp. Neurol., 285: 117-132, 1989.

BASS, N.H.; NETSKY, M.G.; YOUNG, E. Effect of neonatal malnutrition on developing cerebrum. I. Microchemical and histologic study of cellular differentiation in the rat. Arch. Neurol. (Chic.), 23: 289-302, 1970.

CAI, W.Q. \& GABELLA, G. Innervation of the gall bladder and biliary pathways in the guinea-pig. J. Anat., 136; 97-109, 1983.

CAI, W.Q. \& GABELLA, G. Structure and innervation of the musculature at the gastroduodenal junction of the guinea-pig. J. Anat., 139: 93-104, 1984. 
CHASE, H.P.; DABIERE, C.S.; WELCH, N.N.; O'BRIEN, D. Intrauterine undernutrition and brain development. Pediatrics, 47: 491-500, 1971.

CHIANG, C.H. \& GABELLA, G. Quantitative study of the ganglion neurons of the mouse trachea. Cell Tissue Res., 246: 243-252, 1986.

CLARK, G.M.; ZAMENHOF, S.; van MARTHENS, E.; GRAUEL, L.; KRUGER, L. The effect of prenatal malnutrition on dimensions of cerebral cortex. Brain Res., 54: 397-402, 1973.

CONBOY, V.B.; SANTER, R.M.; SWIFT, G.L. Effects of prenatal undernutrition on prevertebral sympathetic neurons in the rat: a morphological and fluorescence histochemical study. J. Anat., 154: 47-53, 1987.

CRAGG, B.G. The development of cortical synapses during starvation in the rat. Brain, 95: 143-150, 1972.

DAVISON, A.N. \& DOBBING, J. Myelination as a vulnerable period in brain development. Brit. med. Bull., 22: 40-44, 1966.

DE ANGELIS, R.C.; TERRA, I.H.C.; MARTINS CAMPOS, J.V. The effect of maturation is source of dietary protein on the capacity of the small intestine to hydrolic lactose in rat. Nutrition Res., 8: 1413-1420, 1088.

DE SOUZA, R.R.; FERRAZ DE CARVALHO, C.A.; LIBERTI, E.A.; FUJIMURA, I. - A quantitative study on the myenteric plexus of the distal end of the human esophagus. Gegen. Morphol. Jb., 134: 565-574, 1988. 
DE SOUZA, R.R.; MORATELLI, H.B.; BORGES, N.; LIBERTI, E.A. Age-induced nerve cell loss in the myenteric plexus of the small intestine in man. Gerontol., 39: 183-188, 1993.

DEO, K.; BIJLANI, V.; DEO, M.G. Effects of malnutrition on cell genesis and migration in developing brain in rats. Exp. Neurol., 62: 80-92, 1978.

EAYRS, J.T. \& hORN, G. The development of cerebral cortex in hypothyroid and starved rats. Anat. Rec., 121: 53-61, 1955.

FILOGAMO, G. \& VIGLIANI, F. Ricerche sperimentali sulla correlazione tra estensione del territorio di ennervazione e grandezza e numero delle cellule gangliari del plesso mienterico (di Auerbach) nel cane. Riv. Patol. nerv. ment., 75: 41-62, 1954.

FULLMER, H.M. The peracetic - orcein - Halui stain: a stain for connective tissues. Stain technol., 34: 81-84, 1959.

GABELLA, G. Neuron size and number in the myenteric plexus of the newborn and adult rat. J. Anat., 109: 81-95, 1971.

GABELLA, G. Structure of the Autonomic Nervous System. Chapman \& Hall, London, 1976.

GABELLA, G. Innervation of the gastrintestinal tract. Int. Rev. Cytol., 59: 129-193, 1979. 
GABELlA, G \& HALASY, K. On the nerve plexus of the chicken gizzard. Anat. Embryol., 177: 97-103, 1987a.

GABELLA, G. The number of neurons in the small intestine of mice, guinea-pig and sheep. Neuroscience, 22(2): 737-752, $1987 \mathrm{~b}$.

GABELLA, G. \& TRIGG, P. Size of neurons and glial cells in the enteric ganglia of mice, guinea-pig, rabbits and sheep. J. Neurocytol., 13:49-71, 1984, 1984.

GABELLA, G.; TRIGG, P.;Mc PHAIL, H. Quantitative cytology of ganglion neurons and satellite glial cells in the superior cervical ganglion of the sheep. Relationship with ganglion neurons size. J. Neurocytol., 17: 753-769, 1988.

GABELLA, G. Fall in the number of myenteric neurons in ageing guineapig. Gastroenterology, 96: 1487-93, 1989.

GABELLA, G. On the plasticity of form and structure of enteric ganglia. J. Auton. Nervous Sys., 30: 859-866, 1990a.

GABELLA, G. Intramural neurons in the urinary bladder of the guineapig. Cell tissues Res., 261: 231-237, 1990b.

GAETANI, S.; MENGHERI, E.; ROSSI, A.; SPADONI, M.A.; TOSCHI, G. Long term protein deficiency in adult rats. Effects on different proteins of a sympathetic ganglion. Neurochemical Res., 2: 439-448, 1977. 
GREENSPAN, F.P. The convenient preparation of peracids. Am. Chem. Soc., 68: 907, 1946.

IRWIN, D.A. The anatomy of Auerbach's plexus. Am. J. Anat., 9: 161166, 1931.

JUNQUEIRA, L.C.U.; BIGNOLAS, G.; BRETANI, R. Picro sirius staining plus polarization microscopy, a specific method for collagen detection in tissue sections. Histochem. J., 11: 447-455, 1979.

KARNOVSKY, M.J. \& ROOTS, L.A. "Direct-Coloring"Thiocoline method for cholinesterases. J. Histochem. Cytochem., 12: 219-221, 1964.

KRAMMER, H.J; KÜHNEL, W. Immunohistochemistry for intermediate filaments in the enteric nervous system of the porcine small intestine. Ann. Anat., 174: 275-278, 1992.

KRAMMER, H.J.; KARAHAN, S.T.; RUMPEL, E.; KLINGER, M.; KÜHNEL, W. Immunohistochemical visualization of the enteric nervous system using antibodies against Protein gene product (PGP) 9.5. Ann. Anat., 175: 321-325, 1993.

LANSDOWN, A.B. Epidermal differentiation in normal and growthretarded infants: studies in two animal models and human babies. Br. J. Dermatol., 99: 139-146, 1978. 
LEPRI, E.R.; BRUSCHI, L.C.; MOURA, A.S. Efeitos da desnutrição protéica durante os períodos pré e pós natal no desenvolvimento cerebelar. Rev. bras. Ciên. morfol., 11(1): 23-27, 1994.

LIBERTI, E.A.; CHADI, G.; DE SOUZA, R.R.; ALVES, N.; PERITO, M.A.M. - A quantitative study of the ganglion neurons of the guinea-pig urinary bladder. Biol. Res., 27: 123-128, 1994

LIBERTI, E.A.; QUEIROZ, L.M.; PERITO, M.A.M.; POMPEU, E.; MORAES, J.O.; MINARELLI, A.M.; DE-SOUZA, R.R- A quantitative and comparative study of the ganglion neurons in the myenteric and submucous plexuses of the small intestine and in the intramural plexus of the gall bladder of the guinea-pig. Rev. Bras. Ciên. morfol., 11 (2): 106-114, 1994.

LIBERTI, E.A.; GOMES, O.A.; DE SOUZA, R.R.- Age-induced nervecell loss in the myenteric plexus of the small intestine in man. Enviado p/ Gerontology, 1995.

MAIFRINO, L.B.; PRATES, J.C.; DE SOUZA, R.R.; ALVES, N.; LIBERTI, E.A. - The number, size and distribution of ganglion neurons in the digestive tract of Calomys callosus. Enviado p/ Acta Anat., 1995.

MECIANO FILHO, J.; CARVALHO, V.C.; DE SOUZA, R.R. Nerve cell loss in the myenteric plexus of the human esophagus in relation to age: A preliminary investigation. Gerontology, 41: 18-21, 1995. 
NAEYE, R.L. Cardiovascular abnormalities in infants malnourished before birth. Biol. Neonate, 8: 104-113, 1965.

OHKUBO, K. Studien uber das intramurale nervesystem des verdaungskanals. II. die plexus myentericus and plexus subserosus des meerschweichens. Jap. J. Med. Sci. Anat., 6: 21-37, 1936.

PALUMBI, G. Differenti aspetti del plesso di Auerbach in regione dei vari segment dell'intestino umano. Ric. Morfol., 13: 538-562, 1933.

PEARSE, A.G.E. Histochemistry. Theoretical and applied. 3rd. ed., London, J \& A Churchill, 1968.

SAMPAIO, S.B. \& COTTA-PEREIRA, G. Distribuição das fibras elásticas, elaunínicas e oxitalânicas na derme superior em pele humana. A. Bras. Dermatol., 46: 333-347, 1971.

SANTER, R.M. \& BAKER, D.M. Enteric neuron numbers and sizes in Auerbach's plexus in the small and large intestine of adult and aged rats. J. Autonom. Nervous Syst., 25: 59-67, 1988.

SANTER, R.M. \& CONBOY, V.B. Prenatal undernutrition permanently decreases enteric neuron number and sympathetic innervation of Auerbach's plexus in the rat. J. Anat., 168: 57-62, 1990. 
SAUER, M.E. \& RUMBLE, C.T. The number of nerve cells in the myenteric and submucous plexuses of the small intestine of the cat. Anat. Rec., 96: 373-381, 1946.

SHIMADA, M.; YAMANO, T.; NAKĀMURA, T.; MORIKAWA, Y; KUSUNOKI, T. Effect of maternal malnutrition on matrix cell proliferation in the cerebrum of mouse embryo: an autoradiographic study. Pediatr. Res., 11: 728-732, 1977.

SHRADER, R.E.; ZEMAN, F.J. Effect of maternal protein deprivation on morphological and enzymatic development of neonatal rat tissue. J. Nutr., 99: 401$412,1969$.

SHRADER, R.E.; ZEMAN, F.J. Skeletal development in rats as affected by maternal protein deprivation and postnatal food supply. J. Nutr., 103: 792-801, 1973.

TAFURI, W.L. Auerbach's plexus in the guinea-pig. I. A quantitative study of the ganglia and nerve cells in the ileum, caecum and colon. Acta Anat., 31: 522-530, 1957.

VERHÖEFF, F.H. Some new staining methods of wide applicability including a rapid differential stain for elastic tissue. J. Am. Med. Ass. (CHicago), 50: 876-877, 1908. 
YAMANO, T.; SHIMADA, M.; YAMASAKI, S.; GOTO, M.; OHOYA, N. Effect of maternal protein malnutrition on the developing cerebral cortex of mouse embryo: an electron microscopic study. Exp. Neurol., 68: 228-239, 1980.

WALLINGFORD, J.C.; SHRADER, R.E.; ZEMAN, F.J. Effect of maternal protein-calorie malnutrition on fetal rat cerebellar neurogenesis. J. Nutr., 110: $543-551,1980$.

WEIGERT, C. Über eine Methode zur Färbung elastischer Fasern. Zbl. All. Path. Pathol. Anat., 9: 289-292, 1898.

WIGGLESWORTH, J. Experimental growth retardation in the foetal rat. J. Pathol. Bacteriol., 88: 1-13, 1964.

ZAMENHOF, S.; van MARTHENS, E.; GRAUEL, L. Prenatal cerebral development: effect of restricted diet, reversal by growth hormone. Science, 174: 954$955,1971$.

ZEMAN, F.J. Effect on the young rat of maternal protein restriction. J. Nutr., 93: 167-173, 1967.

ZEMAN, F.J. Effects of maternal protein restriction on the kidney of the newborn young rats. J. Nutr., 94: 111-116, 1968.

ZEMAN, F.J. Effect of protein deficiency during gestation of postnatal cellular development in the young rat. J. Nutr., 100: 530-538, 1970. 


\section{TRABALHO V}


Editor: M. Ermini, Basel

\section{Reprint}

Publisher: S. Karger AG, Basel

Printed in Switzerland

R.R de Souza

H.B. Moratelli

N. Borges

E.A. Liberti

Department of Anatomy, Institute of Biomedical Sciences, São Paulo University, Brazil

\section{Key Words}

Small intestine

Myenteric ganglia

Aging

\section{Age-Induced Nerve Cell Loss in the Myenteric Plexus of the Small Intestine in Man}

\section{Introduction}

An important aspect of aging is the progressive modification of the number of cell populations. In the myenteric plexus significant reductions in the number of neurons with age were recorded in the guinea pig intestine [1], in the human esophagus [2,3] and in the rat intestine [4]. With regard to the mus- cularis externa it has been suggested that the intestinal muscle which is denervated becomes hypertrophied [5]. In view of these observations it was of interest to see whether a substantial loss of neurons occurred in the different parts of the human small intestine with age and if so whether the muscularis externa is affected.

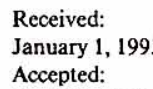

Dr. Romeu Rodrigues de Souza

Department of Anatomy

Av. Prof. Lineu Prestes, 2415

Cidade Universitária

São Paulo (Brazil)
(1) 1993

S. Karger AG, Base 0304-324X/93/

$0394-0183 \$ 2.75 / 0$ 

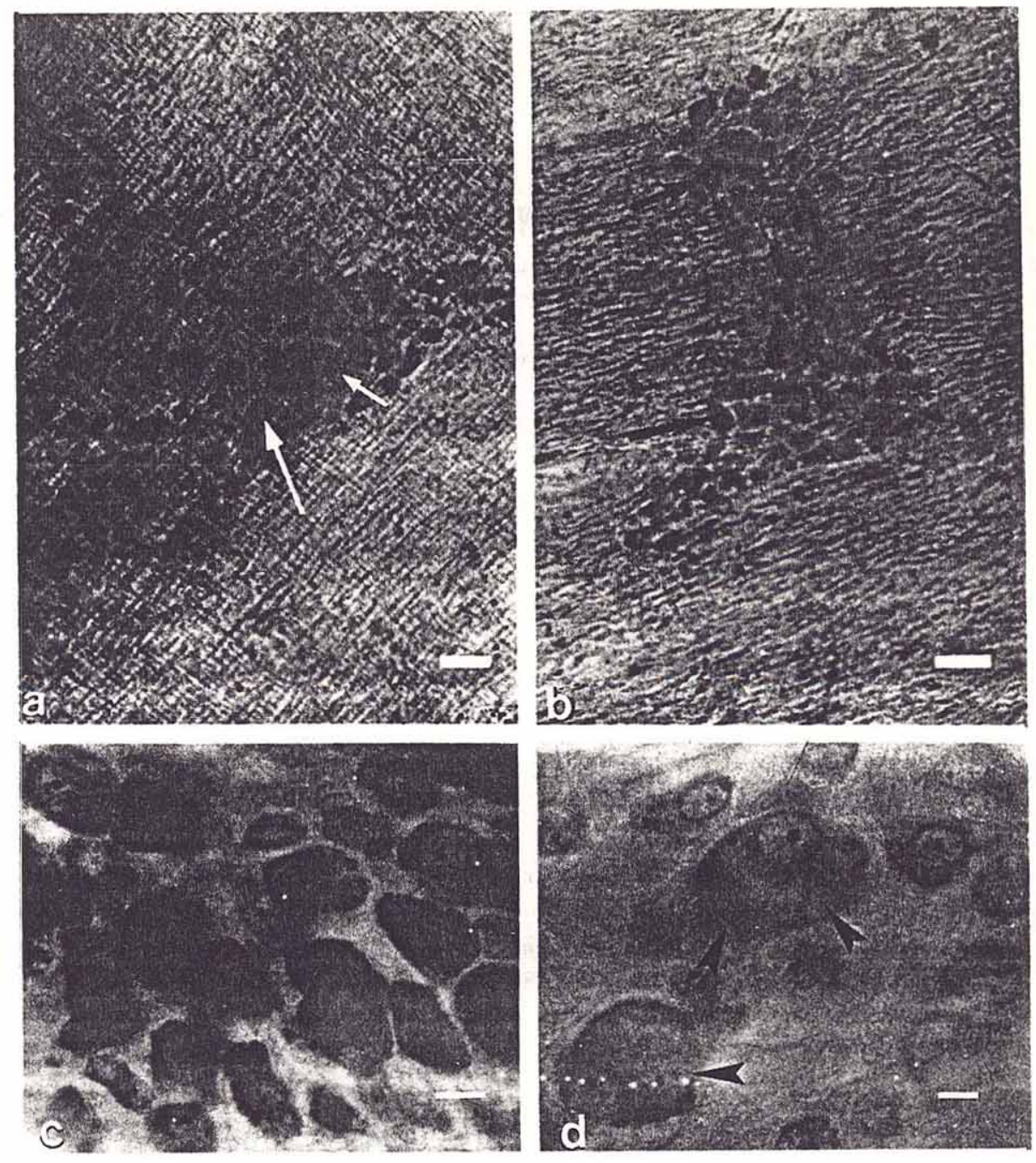

Fig. 1. Whole-mount preparations of the myenteric plexus of the human small intestine. A myenteric ganglion in the young (a) and in the aged (b) jejunum showing a great number of nerve cells (arrows). Calibration bars: $20 \mu \mathrm{m}$. c A group of neurons in a ganglion of young duodenum. Calibration bar: $5 \mu \mathrm{m}$. d Two large neurons (arrowheads) in a ganglion of the aged ileum. Calibration bar: $3 \mu \mathrm{m}$.

\section{Materials and Methods}

Twelve entire small intestines from autopsy material were selected for study. The specimens were divided into two groups. Group 1 consisted of 6 small intestines of young persons, 4 males and 2 females. The average age in this group of patients was $32 \pm 4.9$ years with a range from 20 to 40 years. The second group consisted of 6 elderly individuals, 4 males and 2 females. The average age of this group was $71 \pm 2.3$ years, with a range from 69 to 76 years. Hospital records of all subjects were screened for the presence or absence of neuropathy, alcoholism and Chagas' disease. Patients were excluded when one of these diseases was present during their lifetime. 


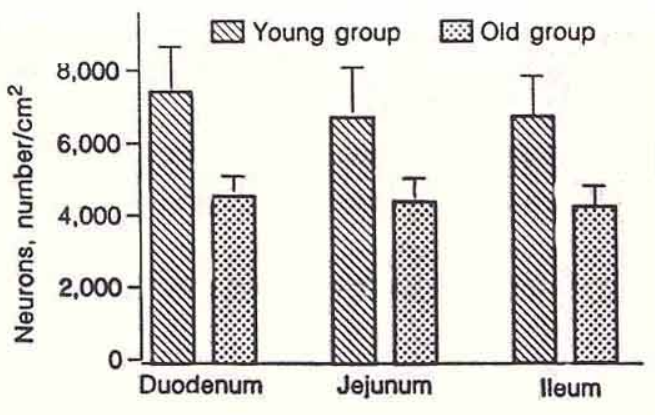

Fig. 2. Numbers of neurons per square centimeter in the small intestine of young and aged individuals. All values show mean $\pm S D . n=6$.

\section{Neuron Counts}

Approximately 1-2 cm length of the duodenum, proximal jejunum and distal ileum were removed from 12 intestines. The diameter of the gut was then measured and recorded for each region. Each fresh piece was then subdivided into fragments measuring 0.5 $\mathrm{cm}^{2}$, of which $50 \%$ were randomly selected for study. The fragments were immersed in fixative solution (formaldehyde acetic) [6] where they were dissected under a stereomicroscope, removing the mucosa, submucosa and part of the circular muscle layer. All the fragments were then stained according to the Giemsa method [6], washed, dehydrated, cleared in xylene, and mounted in synthetic resin (fig. 1).

In order to estimate neuron density (number of neurons $/ \mathrm{cm}^{2}$ ) of the intestinal wall, the number of nerve cells was counted in 20 microscope fields per fragment (field area $=0.45 \mathrm{~mm}^{2}$ ), located by means of two orthogonal coordinates taken from a table of random numbers and measured on the movable stage of the microscope. Conventionally, the nerve cells intersected by the field's superior and inferior hemicircumferences were, respectively, disregarded and considered. The total number of cells per square centimeter in each region was then estimated, considering the total area of all microscopic fields taken at the same region.

In order to take into account the slight differences in the diameter of the pieces of gut and the reduction of the intestinal area during the laminar preparations, the means of the diameters were calculated for each region and the percentage of reduction was calculated by mea- suring the area of the fragments before fixation and after it had been mounted on a microscopic slide and, afterwards, used as a correction factor when expressing the counts per square centimeter.

\section{Thickness of the Muscularis externa}

Rings of $1 \mathrm{~cm}$ length of the duodenum, jejunum and ileum were removed from 6 individuals ( 3 from young persons and 3 from the elderly group), fixed in Bouin's and used to make histological $10-$ to $15-\mu \mathrm{m}$ transverse sections that were stained with the hematoxylin-eosin method in order to measure the thickness of the muscularis externa. Multiple measurements at regular intervals were performed on each section and thickness of circular and longitudinal muscle coats was expressed by means of these measurements. For statistical analysis the Student $t$ test was used.

\section{Results}

The method used allowed an adequate identification of the perikarya of the nerve cells and their distinction in relation to the satellite and muscle cells. The ganglia were easily recognized; the nerve cell perikaryon stained well and the nucleus stained as a black ring containing a black nucleolus. The stained neurons of the three regions of the small intestine formed a fairly homogeneously sized and rounded population (fig. 1). In the old persons the overall neuronal staining intensity was less than in the young persons.

\section{Neuron Counts}

The number of neurons in the three regions of the intestine under study relating to the young and elderly persons is presented in figure 2 . The average nerve cell count per square centimeter in elderly persons was $4,663 \pm$ 400 (mean \pm SD) in the duodenum, 4,583 \pm 383 in the jejunum and 4,376 \pm 414 in the ileum. In young persons it was 7,506 $\pm 1,081$, $6,900 \pm 1,269$ and $6,907 \pm 914$, in the duodenum, jejunum and ileum, respectively. In all cases there was a significant difference $(p<$ 0.01 ) in the number of neurons between the 


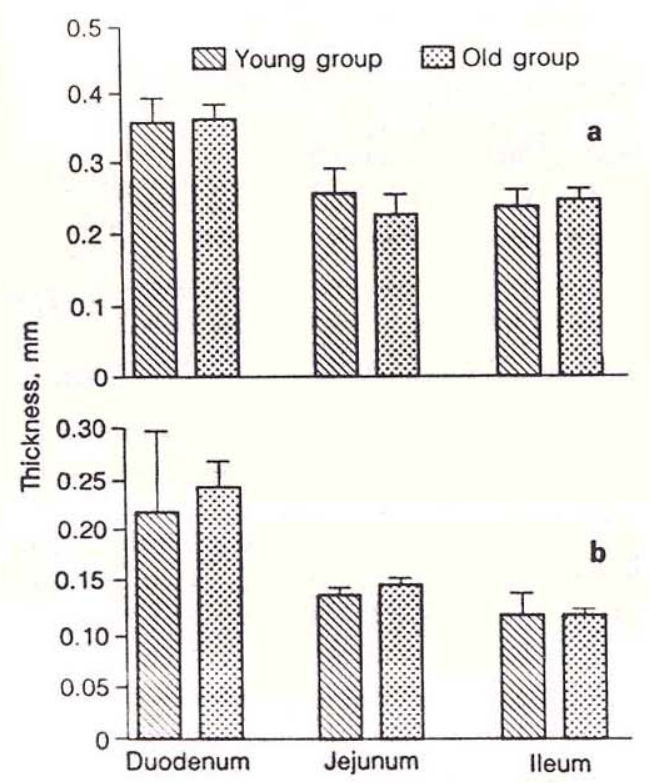

Fig. 3. Thickness of circular (a) and longitudinal (b) muscle layers in the small intestine of young and aged individuals. All values show mean \pm SD. $n=3$.

two groups (young and aged). In percentage terms the three regions of the intestine show a decrease in the number of neurons of at least $34 \%$ with the most pronounced being $38 \%$ in the duodenum.

\section{Thickness of the Muscularis externa}

At all three levels of the small intestine where measurements were performed we could not detect a difference in the thickness of the smooth muscle layers, both the circular (fig. 3a) and the longitudinal (fig. 3b), between the two age groups.

\section{Discussion}

The usefulness of the nonhistochemical technique employed in this work for the investigation of the number of the myenteric neurons has been demonstrated previously [7-9]. This technique seems to be very reliable and constant and in addition, it can be used in postmortem material.

The present study has shown that the Giemsa staining can be used to investigate neurons in tissue taken from aged subjects. It should be clearly stated that none of the counts in either the young adult or aged tissue was ever affected by dubious levels of staining intensity. As mentioned above the staining intensity in neurons of the small intestine in the aged group was less intense than in the small intestine of the younger group. It is possible that the dye may have completely failed to penetrate the longitudinal muscle layer, thus leaving the neurons less stained. It is also possible that there were a very few neurons that did not stain with this method. However, it is likely that the vast majority, at least of the myenteric neurons, was stained.

In order to ensure a minimum influence of technical factors upon the results, during the dissections a great part of the circular muscle layer was carefully separated so as to leave the plexus attached to the longitudinal one.

The results of our study suggest that there is a decrease in the density of nerve cells in the myenteric plexus throughout the small intestine in aged humans. The percentage decreases in neuron numbers reported above closely correspond to that described for the rat intestine [4] and for the guinea pig small intestine [1] but our figures are higher than that reported for the human esophagus [2, 3]. In the young individuals the numbers of neurons in the jejunum are higher than that previously reported [8] but our figures for the duodenum correspond more closely. These variations could be explained by differences in the absolute amount of smooth muscle in the regions of the intestine and by other factors concerning the architecture and connectivity within the plexus. 
The decrease in the number of neurons of the myenteric plexus with age is interpreted as an indication that a part of the neuronal population disappears from the ganglia in old individuals. It was suggested that the loss of myenteric neurons with age is probably due to nerve cell death [1]. However, the loss of neurons should not necessarily be regarded as a degenerative process of the myenteric plexus. It might simply eliminate redundant neurons or might result from the increased efficiency of the surviving elements [1]. Taken as a whole, the evidence suggests that the intrinsic innervation of the human small intestine is reduced in old age.

It has been suggested that intestinal muscle which is partially or completely denervated becomes grossly hypertrophied [5]. Although there was a significant decrease of nerve cells in our elderly subjects we could not detect an increase in intestinal muscle thickness. The same conclusion has been obtained in a comparable study in the human esophagus [2].

Recent publications identified several types of neurotransmitters in the muscularis externa of the human small intestine [10-12]. The decrease in the number of neurons could affect the enteric neurotransmitter system and the potency of their varying actions upon the intestinal function could consequently be reduced.
However, concerning the age-related changes of several small intestinal functional parameters, conflicting results have been obtained in different physiological studies. According to some authors [13] there is an agerelated impairment in the general digestive capacity of individuals without a manifestation of gastrointestinal disorders. Others [14] are of the opinion that the capacity to digest and/or absorb large amounts of dietary protein is reduced in the elderly as a function of age; according to some investigations [15] protein digestion and absorption are similar in young and old individuals.

To explain these results, we can postulate that, as in many other neuronal systems [16], an initial overprovisioning takes place during the colonization of the gut by neurons during development and that subsequent nerve cell losses during life could affect intestinal functions and structure.

Therefore, a more defined answer about to what extent the functions of the intestine are affected by the reduction in number of neurons can only be given by further experimental and physiological studies.

\section{Acknowledgements}

R.R. de Souza is career investigator of $\mathrm{CNPq}$ in Biology of Ageing. The study was supported in part by a grant from the Sandoz Foundation for Gerontological Research.

\section{References}

1 Gabella G: Fall in the number of myenteric neurons in aging guineapigs. Gastroenterology 1989;96: 1487-1493.

2 Eckardt VF, LeCompte PM: Esophageal ganglia and smooth muscle in the elderly. Dig Dis 1978;23:443448.
3 Koeberle F: Chagas' disease and Chagas' syndrome: The pathology of American trypanosomiasis. Adv $\mathrm{Pa}$ rasitol 1968;6:63-116.

4 Santer RM, Baker DM: Enteric neuron number and sizes in Auerbach's plexus in the small and large intestine of young adult and aged rats. $J$ Auton Nerv Syst 1988;25:59-67.
5 Smith B: The autonomic innervation of the esophagus. Clin Gastroenterol 1976;5:1-13.

6 Barbosa JA: Tecnica histologica para ganglios nervosos intramurais em preparados espessos. Rev Bras Pesq Med Biol 1978;11:95-97. 
7 De Souza RR, Ferri S, Ferraz de Carvalho CA, Paranhos GS: Myenteric plexus in a freshwater teleost intestine. I. Quantitative study of nerve cells. Anat Anz 1982;152: 359-362.

8 Ferraz de Carvalho CA, De Souza RR, Oliveira CA, Hamada GS, Pego-Fernandes PM: A quantitative study on the myenteric plexus of the distal end of the duodenum and the proximal part of the jejunum. Gegenbaurs Morphol Jahrb 1983;129: 51-56.

9 De Souza RR, Ferraz de Carvalho CA, Liberti EA, Fujimura I: A quantitative study on the myenteric plexus of the distal end of the human esophagus. Gegenbaurs Morphol Jahrb 1988;134:565-574.
10 Ferri GL, Wright NA, Soimero GL, Polak JM: Quantification of the intestinal peptide-containing innervation. Length density of nerve fibers and total length of nerve supply to the single villus/cript unit. J Histochem Cytochem 1984;32:737-740.

11 Llewellyn-Smith IJ, Furness JB, Murphy R, O'Brien PE, Costa M: Substance P-containing nerves in the human small intestine. Distribution, ultrastructure and characterization of the immunoreactive peptide. Gastroenterology $1984 ; 86$ : 421-435.

12 Llewellyn-Smith IJ, Furness JB, O'Brien PE, Costa M: Noradrenergic nerves in the human small intestine. Distribution and ultrastructure. Gastroenterology 1984;87: 513-529.
13 Kountz WB, Ackermann PG, Kheim T, Toro G: Effects of increased protein intake in older people. Geriatrics 1953;8:63-69.

14 Werner I, Hambreaus L: The digestive capacity of elderly people. The effect of a high proptein diet. Acta Soc Med Ups 1971;76:239-242.

15 Chinn AB, Lavik PS, Cameron DB: Measurement of protein digestion and absorption of aged persons by test meal of $\mathrm{I}^{131}$ labelled protein. J Gerontol 1956;11:151-163.

16 Williams RW, Herrup K: The control of neuron number. Annu Rev Neurosci 1988;11:432-453. 
TRABALHO VI 
From the Departamento de Anatomia, Instituto de Ciências Biomédicas da Universidade de São Paulo, Cidade Universitária São Paulo (Brasil) (Head: Prof. Dr. C. A. Ferraz de Carvalho)

\title{
A Quantitative Study on the Myenteric Plexus of the Distal End of the Human Esophagus
}

\author{
By \\ With 5 Figures and 7 Tables \\ Received November 4, 1987
}

Romeu R. de Souza, Claudio A. Ferraz de Carvalho, Edson A. Liberti and Ikurou Fujimura

\begin{abstract}
The densities of ganglia and nerve cells in the myenteric plexus of the last distal $11 \mathrm{~cm}$ of the human esophagus were determined in 6 esophagi from autopsy material.

The densities of ganglia and nerve cells in cresyl violet-stained stretch preparations of 11 esophageal segments, each $1 \mathrm{~cm}$ in length, were compared. The highest values were recorded in segments 4,5 , and $6 \mathrm{~cm}$ above cardiac incisura. The lowest densities of ganglia and nerve cells were found in segments 1,2 , and $3 \mathrm{~cm}$ above the cardiac incisura. The segments contained 659 to 3,316 perikarya $/ \mathrm{cm}^{2}$ and 31 to 110 ganglia $/ \mathrm{cm}^{2}$; ganglia contained 3 to 310 cells.
\end{abstract}

\section{Introduction}

The number of nerve cells in the myenteric ganglia is considerable and varies in the different segments of the alimentary canal. Quantitative studies suggest that the packing density of intramural neurons is higher in portions of the myenteric plexus associated with sphincteric regions of the gut. A greater number of nerve cells has been observed in the region of the duodenojejunal flexure (FERRAZ de CARvalho et al. 1983) where a functional sphincter is described (VILLEMI 1911, Didio and ANDERSON 1968) and in regions where a typical sphincter occurs as in the gastroduodenal transition (Stöhr 1930, Dos Santos 1931, Indar Jit 1955, Damia NI and Battistelli 1956) and in the terminal ileum (Palumbi 1933, Indar Jit 1956).

The human esophagus is separated from the stomach by a physiological sphincter, the lower esophageal sphincter (LES), corresponding to the last $3 \mathrm{to} 4 \mathrm{~cm}$ of the esophagus (Christenser 1978). Nerve cell concentration in the myenteric plexus apparently increases progressively in the lower esophageal segments (KADA NOFF and Spassova 1959, Cecio et al. 1976) although Koberle et al. (1972), Eckhardt and 
LECoMpte (1978) have encountered a fairly uniform distribution in the number of nerve cells per $\mathrm{cm}^{2}$ in the human esophagus.

The present investigation was undertaken to determine the densities of nerve cells and ganglia of the myenteric plexus in the last $11 \mathrm{~cm}$ of the human esophagus, including the region of the lower esophageal sphincter.

\section{Material and Methods}

6 esophagi from autopsy material were selected for study. The esophagus above the cardiac incisura was removed and opened along the lesser curvature of the stomach. The tissue so obtained was slightly stretched on cardboard, fixed by pins, to avoid retractions, washed with saline, neasured and inmediately immersed in a solution of $10 \%$ formalin for $10 \mathrm{~d}$.

The esophagus was then cut into 11 segments of about $1 \mathrm{~cm}$ length which were subdivided into fragments measuring $0.5 \mathrm{~cm}^{2}$ of which $50 \%$ were used for study; Fig. 1 shows the manner in which these fragnents wore selected.

Each fragment was inmersed in a solution of $0.5 \%$ cresyl violet for $12 \mathrm{~h}$, then washed, dehydrat.d. and cleared in xylene.

Th.. nuscosa, submucesa, and circular and longitudinal muscles of each fragment were dissected under a stereomicroseope leaving only the myenteric plexus and the intermuscular connective tissue. Dissection at this phase was more convenient since xylene clarifies and hardens the specimens, avoiding artificial distension. Incompletely stained fragments were rehydrated and restained. From each esophagus, there were 11 segments, 7 or 8 representing the esophageal body and the last 3 or 4 the lower esophageal sphincter. A diagram of the esophagus, the 11 segments into which it was divided, the terms used to describe these segments and the manner in which the fragments were selected for study appear in Fig. 1. After dissection, the preparations were mounted in synthetic resin (Fig. 2).

Perikarya and ganglia were counted using a magnification of $\times 100$ or $\times 160$. All the ganglia and perikarya in each fragment were counted and the total number of ganglia and cells per $\mathrm{cm}^{2}$ was then estimated for each segment.

The Gosser's ("Student's") test (SNenrcor and Cochrax 1967) was used for statistical analysis.

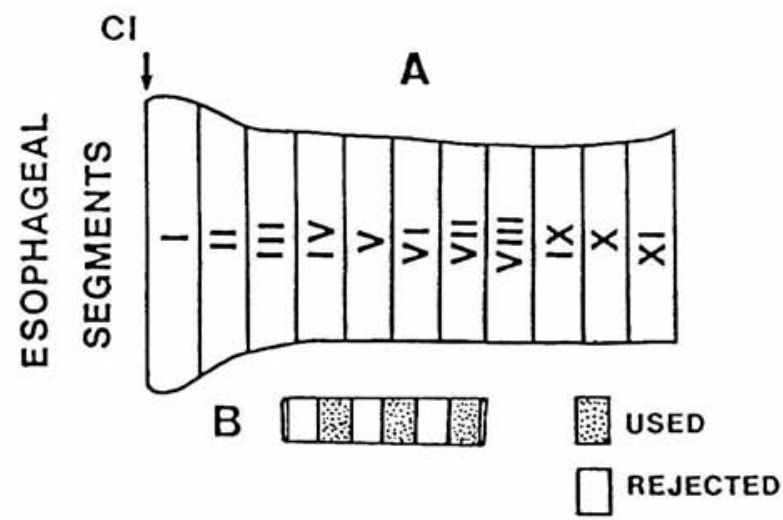

Fig. 1. A) Diagram of the esophagus that was examined as it was dissected. Roman numerals indicate the segments referred to in the text. CI level of the cardiac incisura. B) Diagram of one segment, showing the manner as the fragments were selected for study 


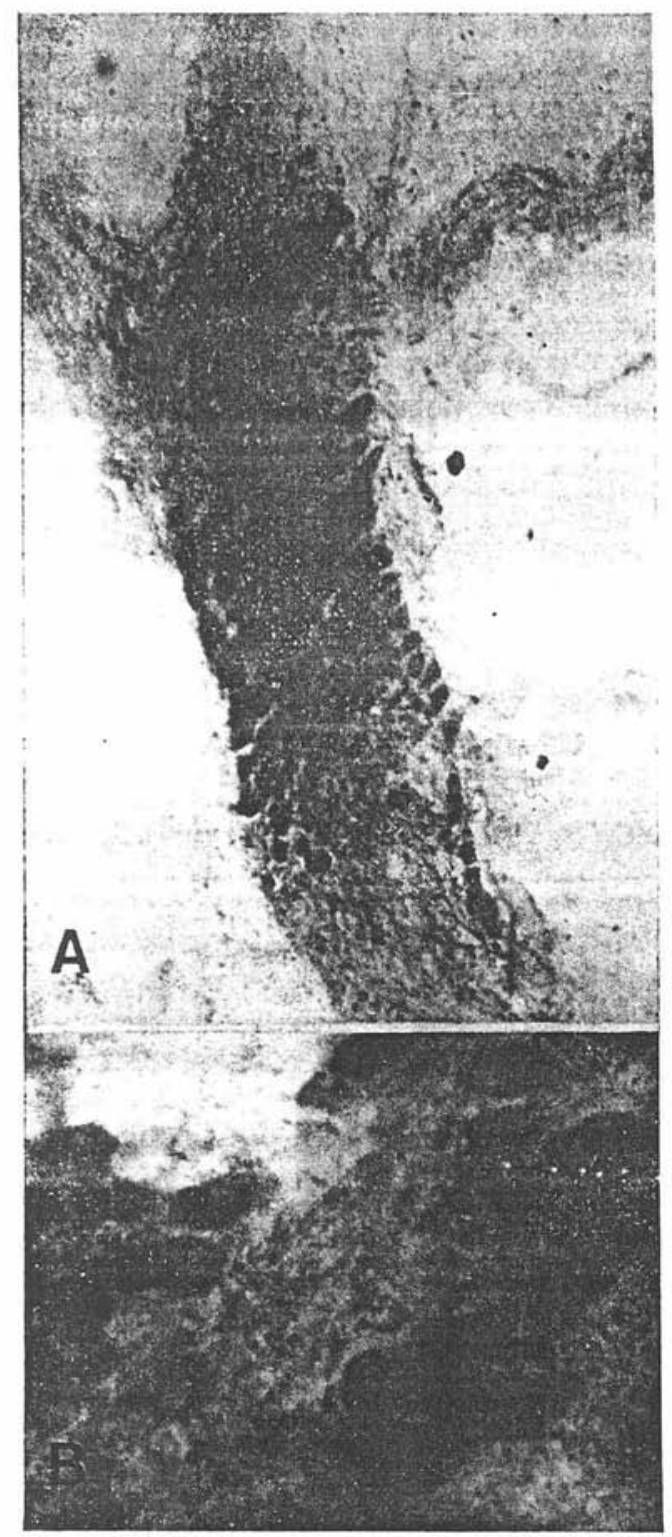

Fig. 2. Stretch preparation from the human esophagus. A) a ganglion $(\times 15)$ and $B)$ the nerve cells of the myenteric plexus $(\times 40)$. Cresyl violet

\section{Results}

In dissections the 2 muscle layers always separate cleanly and the colour density varied sowewhat from specimen to specimen. The ganglia were easily recognized, for the perikarya stain well and the nucleus stains as a black ring containing a black nucleolus. 


\subsection{Nerve cell density}

The results of the counts on preparations from 6 esophagi are shown in Tab. 1 and Fig. 3 . The highest nerve cell density was found in segments IV, V, and VI and the lowest in segments I, II, and III.

Statistical analysis was performed considering all 11 segments distributed in 3 groups, according to their nerve cell density: group A (segments I, II, III); group B (segments IV, $\mathrm{V}, \mathrm{VI}$ ), and group $\mathrm{C}$ (segments VII, VIII, IX, X, XI).

The segments of group A contained 659 to 1.977 nerve cells/ $/ \mathrm{cm}^{2}$, those of group B contained 1,251 to 3,316 nerve cells $/ \mathrm{cm}^{2}$, and those of group $\mathrm{C}$ contained 857 to $2,359 / / \mathrm{cm}^{2}$. Statistical analysis showed significant differences among the groups. The a verage number of nerve cells per $\mathrm{cm}^{2}$ is significantly higher in group B than in groups $\mathrm{A}(p<0.01)$ and $\mathrm{C}(p<0.05)$. The are no significant differences among the remaining groups of esophageal segments: data appear in Tab. 2.

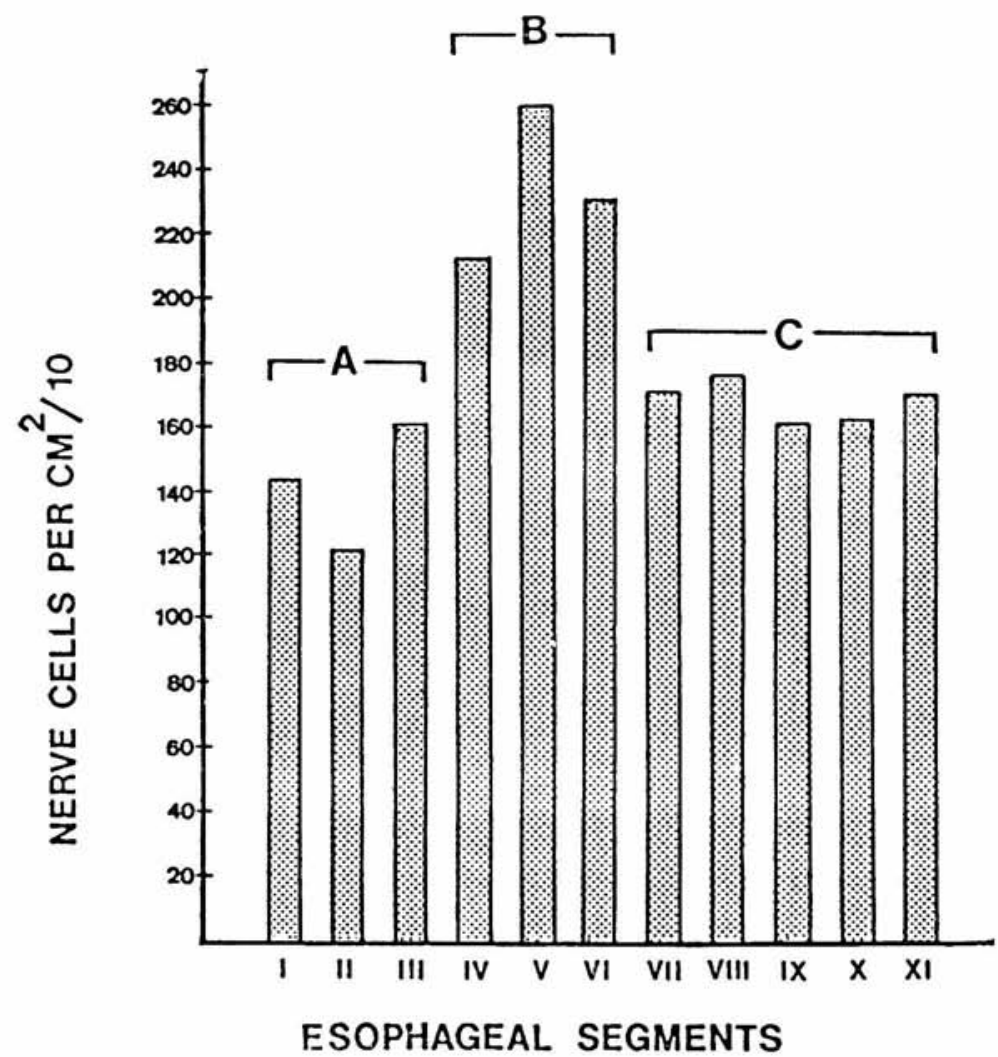

Fig. 3. Nerve cell density along smooth muscle segments of 6 esophagi. The abscissa identifies the 11 segments as defined in Fig. 1. The ordinate is the number of nerve cells calculated per unit area. The colums represent the count made as described in the text. A, B, C groups of segments according to nerve cell density 
R. R. DF Sotza et al.: A Quantitative Study on the Myenteric Plexus ...

Table 1. Density of perikarya (nerve cells $/ \mathrm{cm}^{2}$ along the 11 esophageal segments (I to IX)

\begin{tabular}{|c|c|c|c|c|c|c|c|}
\hline \multirow{2}{*}{$\begin{array}{l}\text { Esophageal } \\
\text { segment }\end{array}$} & \multicolumn{6}{|c|}{ Specimen } & \multirow{2}{*}{$\begin{array}{l}\text { Mean } \pm 1 \text { SD } \\
{\left[\text { cells } / \mathrm{cm}^{2}\right]}\end{array}$} \\
\hline & 1 & 2 & 3 & 4 & 5 & 6 & \\
\hline I & 1,721 & 1,772 & 1,710 & 1,062 & 1,093 & 1,207 & $1,427 \pm 340$ \\
\hline II & 1,750 & 1,225 & 1,740 & 659 & 1,068 & 795 & $1,206 \pm 462$ \\
\hline III & 1,672 & 1,746 & 1,670 & 849 & 1,743 & 1,977 & $1,609 \pm 389$ \\
\hline IV & 2,205 & 2,099 & 2,201 & 1,251 & 2,361 & 2,260 & $2,129 \pm 472$ \\
\hline V & 3,316 & 2,355 & 3,220 & 1,549 & 2,281 & 2,873 & $2,599 \pm 669$ \\
\hline VI & 2,846 & 2,352 & 2,842 & 1,401 & 1,988 & 2,429 & $2,309 \pm 550$ \\
\hline VII & 1,827 & 1,425 & 1,843 & 1,136 & 1,667 & 2,359 & $1,709 \pm 415$ \\
\hline VIII & 1,698 & 1,756 & 1,702 & 857 & 1,975 & 2,591 & $1,763 \pm 568$ \\
\hline IX & 2,269 & 1,201 & 2,260 & 912 & 1,152 & 1,894 & $1,614 \pm 600$ \\
\hline $\mathrm{x}$ & 1,995 & 1,537 & 1,980 & 927 & 1,303 & 2,063 & $1,634 \pm 458$ \\
\hline XI & 1,220 & 1.916 & 1,940 & 1,233 & 1,324 & 1.868 & $1,700 \pm 32 \mathrm{~s}$ \\
\hline
\end{tabular}

Table 2. 1)ensity of perikarya (nerve cells/cm²) along groups of esophageal segments $(A, B, C)$

\begin{tabular}{|c|c|c|c|c|c|c|c|}
\hline \multirow{2}{*}{$\begin{array}{l}\text { Groups of } \\
\text { esophageal } \\
\text { segments }\end{array}$} & \multicolumn{6}{|c|}{ specimen } & \multirow{2}{*}{$\begin{array}{l}\text { Mean } \pm S D \\
{\left[\text { cells } / \mathrm{cm}^{2}\right]}\end{array}$} \\
\hline & 1 & 2 & 3 & 4 & 5 & 6 & \\
\hline $\begin{array}{l}\text { A (1 to } 3 \mathrm{~cm} \\
\text { above } \mathrm{CI})^{1}\end{array}$ & 1,714 & 1,581 & 1,706 & 856 & 1,301 & 1,326 & $1,414 \pm 327$ \\
\hline $\begin{array}{l}\mathrm{B}(4 \text { to } 6 \mathrm{~cm} \\
\text { above } \mathrm{CI})\end{array}$ & 3,524 & 2,268 & 2,754 & 1,400 & 2,210 & 2,654 & $2,468 \pm 704^{*}$ \\
\hline $\begin{array}{l}\mathrm{C}(7 \text { to } 11 \mathrm{~cm} \\
\text { above } \mathrm{CI})\end{array}$ & 1,941 & 1,567 & 1,945 & 1,013 & 1,484 & 2,155 & $1,684 \pm 414$ \\
\hline
\end{tabular}

${ }^{1}$ CI cardiac incisura. * Greater than group $\mathrm{A}(\mathrm{p}<0,01)$ and group $\mathrm{C}(\mathrm{p}<0.05)$.

Table 3. Density of ganglia (ganglia/ $/ \mathrm{cm}^{2}$ ) along the 11 esophageal segments (I to XI) from 6 esophagi

\begin{tabular}{llllllll}
\hline $\begin{array}{l}\text { Esophageal } \\
\text { segment }\end{array}$ & \multicolumn{2}{l}{ Specimen } & & & & \multicolumn{2}{c}{$\begin{array}{l}\text { Mean } \pm \text { SD } \\
\text { [ganglia/cm }\end{array}$} \\
\cline { 2 - 6 } & 1 & 2 & 3 & 4 & 5 & 6 & \\
\hline I & 51 & 71 & 49 & 60 & 43 & 45 & $53 \pm 10$ \\
II & 56 & 47 & 56 & 44 & 45 & 34 & $47 \pm 8$ \\
III & 39 & 51 & 37 & 33 & 49 & 63 & $45 \pm 11$ \\
IV & 56 & 58 & 54 & 47 & 58 & 69 & $57 \pm 7$ \\
V & 66 & 76 & 63 & 39 & 59 & 70 & $62 \pm 12$ \\
VI & 53 & 62 & 51 & 33 & 57 & 110 & $61 \pm 25$ \\
VII & 46 & 52 & 45 & 35 & 41 & 73 & $48 \pm 13$ \\
VIII & 40 & 58 & 38 & 33 & 31 & 85 & $47 \pm 20$ \\
IX & 54 & 37 & 53 & 34 & 45 & 77 & $50 \pm 15$ \\
X & 40 & 50 & 38 & 44 & 40 & 71 & $47 \pm 12$ \\
XI & 49 & 57 & 47 & 33 & 39 & 63 & $48 \pm 10$ \\
\hline
\end{tabular}

39 Morph. Jb. 134/4 


\subsection{Ganglion density}

We arbitrarily defined a ganglion as a cluster of 3 or more perkarya. The results of the counts on preparations from 6 esophagi are shown in Tab. 3 and lig. 4.

As to the nerve cell density, statistical analyses were performed considering all 11 segments distributed in 3 groups, according to their ganglion density: the segments I, II, and III (group A) contained 34 to 71 ganglia/ $\mathrm{cm}^{2}$, the segments IV, V, VI (group B) contained 33 to 110 ganglia/ $\mathrm{cm}^{2}$, and the segnents VII to XI (group (C) contained 31 to 77 ganglia/ $\mathrm{cm}^{2}$. The average number of ganglia/ $\mathrm{cm}^{2}$ is higher in group $B$ than in the remaining groups. However, statistical analysis showed no significant differenees among the groups. Data appear in Tab. 4.

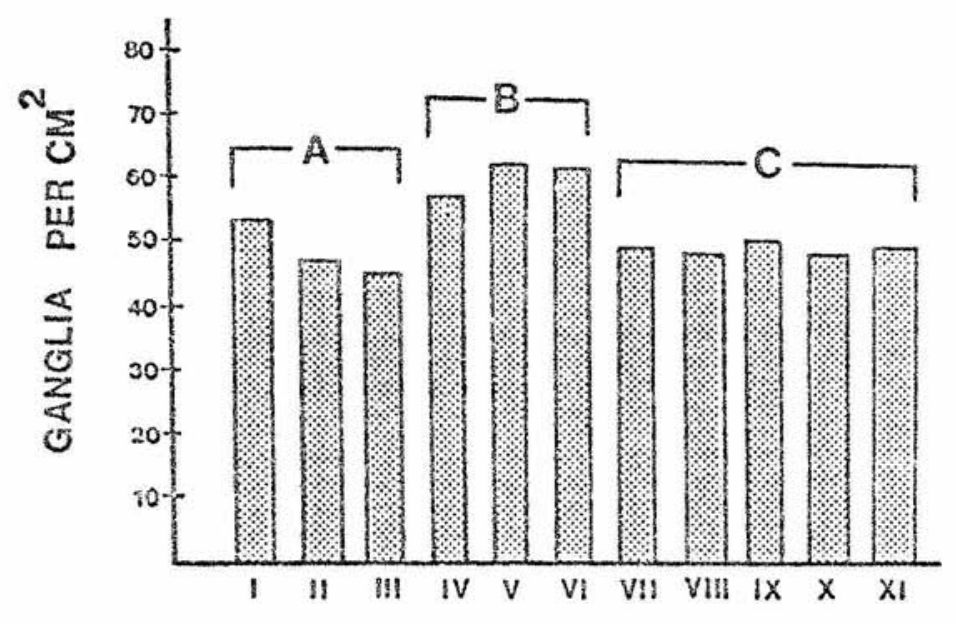

\section{ESOPHAGEAL SEGMENTS}

Fig. 4. Gangìion density along smooth muscle segments of 6 esophagi. Tho aibtisera identifies the 11 segments as defined in Fig. 1. The ordinate is the number of ganglia calculated por unit area. The colums represent the count made as described in the text. A, B, C groups of segments according to ganglion density

Table 4. Density of gangiia (gangiia/ $\left.\mathrm{cm}^{2}\right)$ along groups of esophageal segnon's $(\mathrm{A}, \mathrm{B}, \mathrm{C})$

\begin{tabular}{|c|c|c|c|c|c|c|c|}
\hline \multirow{2}{*}{$\begin{array}{l}\text { Groups of } \\
\text { esophagorl } \\
\text { segments }\end{array}$} & \multicolumn{6}{|c|}{ Specimen } & \multirow{2}{*}{$\begin{array}{l}\text { Mean } \pm S D \\
{\left[\text { ganglia/cn }{ }^{2}\right]}\end{array}$} \\
\hline & 1 & 2 & 3 & 4 & 5 & 6 & \\
\hline $\begin{array}{l}\text { A (1 to } 3 \text { Wh } \\
\text { above } \mathrm{CI})\end{array}$ & 49 & 56 & 47 & 46 & 46 & 47 & $48 \pm 4$ \\
\hline $\begin{array}{l}\mathrm{B}(4 \text { to } 6 \mathrm{~cm} \\
\text { above } \mathrm{CI})\end{array}$ & 58 & $6 C$ & 56 & 40 & 58 & 83 & $60 \pm 14$ \\
\hline $\begin{array}{l}\mathrm{C}(7 \text { to } 11 \mathrm{~cm} \\
\text { above } \mathrm{CI})\end{array}$ & 48 & 51 & 44 & 36 & 39 & 74 & $48 \pm 13$ \\
\hline
\end{tabular}




\subsection{Classes of ganglia}

Ganglion size varied along each esophagus. It was assessed by computing the number of nerve cells in all ganglia, in all 6 specimens. 2 classes of ganglia were considered:

a) ganglia containing 3 to $\mathbf{4 0}$ nerve cells per ganglion;

b) ganglia containing more than $\mathbf{4 0}$ nerve cells per ganglion.

The average number of ganglia containing 3 to 40 nerve cells per ganglion appear segment by segment in Tab. 5 and Fig. 5 . There are no significant differences among them.

Table 5. Density of ganglia (ganglia/ $\mathrm{cm}^{2}$ ) containing 3 to 40 nerve cells per ganglion, along the 11 segments (I to XI) from 6 esophagi

\begin{tabular}{llllllll}
\hline $\begin{array}{l}\text { Esophageal } \\
\text { segments }\end{array}$ & \multicolumn{2}{l}{ Specimen } & & & & \multicolumn{1}{c}{$\begin{array}{l}\text { Mean } \pm \text { SI } \\
\text { [ganglia/cm }\end{array}$} \\
\cline { 2 - 6 } & 1 & 2 & 3 & 4 & 5 & 6 & \\
\hline I & 33 & 58 & 32 & 57 & 34 & 34 & $41 \pm 12$ \\
II & 41 & 35 & 42 & 41 & 39 & 26 & $37 \pm 5$ \\
III & 24 & 68 & 25 & 26 & 30 & 41 & $36 \pm 17$ \\
IV & 34 & 36 & 34 & 38 & 38 & 45 & $37 \pm 4$ \\
V & 36 & 54 & 27 & 27 & 33 & 44 & $37 \pm 10$ \\
VI & 26 & 38 & 26 & 19 & 39 & 91 & $40 \pm 26$ \\
VII & 30 & 39 & 29 & 25 & 22 & 50 & $32 \pm 10$ \\
VIII & 23 & 41 & 23 & 23 & 20 & 59 & $31 \pm 15$ \\
IX & 32 & 24 & 32 & 30 & 35 & 61 & $36 \pm 13$ \\
X & 24 & 34 & 22 & 36 & 30 & 55 & $33 \pm 12$ \\
XI & 21 & 38 & 29 & 23 & 30 & 46 & $31 \pm 9$ \\
\hline
\end{tabular}

NERVE CELLS/ GANGLION

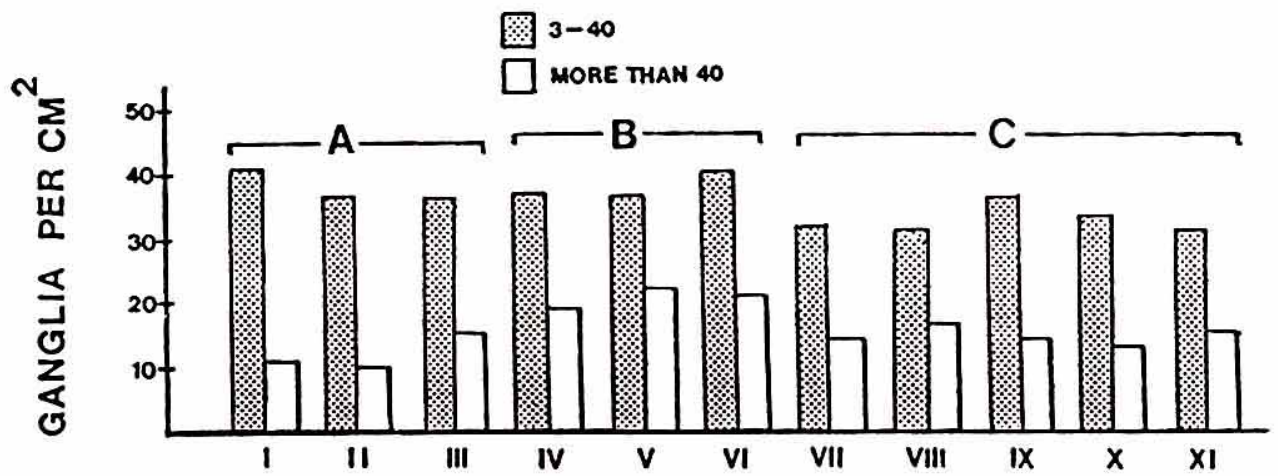

ESOPHAGEAL SEGMENTS

Fig. 5. Density of ganglia/ $\mathrm{cm}^{2}$ according to the number of nerve cells per ganglion. The abcissa identifies the 11 segments as defined in Fig. 1. The ordinate is the number of ganglia calculated per unit area. At each level, bars show number for each of the 2 classes of ganglia. A, B, C groups of segments according to ganglion density 
Table 6. Density of ganglia (ganglia/(-m²) containing more than 40 nerve cells per ganglion, along 11 segments (I to XI) from 6 esophagi

\begin{tabular}{|c|c|c|c|c|c|c|c|}
\hline \multirow{2}{*}{$\begin{array}{l}\text { Esophageal } \\
\text { segnu'nts }\end{array}$} & \multicolumn{6}{|c|}{ Specimen } & \multirow[t]{2}{*}{ Mean $\pm S 1)$} \\
\hline & 1 & 2 & 3 & 4 & 5 & 6 & \\
\hline 1 & 17 & 14 & 17 & 3 & 7 & 11 & $11 \pm 6$ \\
\hline II & 15 & 12 & 17 & 4 & 6 & 8 & $10 \pm 5$ \\
\hline 111 & 13 & 20 & 12 & 6 & 19 & 22 & $15 \pm 6$ \\
\hline 11 & 18 & 21 & 19 & 9 & 23 & 23 & $19 \pm 5$ \\
\hline$r$ & 28 & 22 & 24 & 11 & 25 & 27 & $22 \pm 6$ \\
\hline 11 & 25 & 23 & $20 i$ & 14 & $1 !$ & $1 !$ & $21 \pm 4$ \\
\hline 111 & 14 & 15 & 16 & 6 & 19 & 23 & $14 \pm 6$ \\
\hline VIII & 16 & 16 & 15 & 12 & 11 & 26 & $16 \pm 7$ \\
\hline IX & 20 & 13 & 21 & 4 & 111 & 16 & $14 \pm 7$ \\
\hline$x$ & 1.5 & 14 & $16 i$ & $s$ & 111 & $16 i$ & $13 \pm 3$ \\
\hline 11 & 17 & is & 20 & 11 & $x$ & 17 & $15 \pm 5$ \\
\hline
\end{tabular}

As regards 10 the ganglia containing more than 40 nerve cells per ganglion, the segments 1, II, III (group A) contained 10 to 15 ganglia/ $\mathrm{cm}^{2}$, the segments IV, V, VI (group B) contained 19 to 22 ganglia/ $\mathrm{cm}^{2}$, and the segments VII to XI (group C) contained 13 to 16 ganglia/cm² (Tab. 6, Fig. 5). Statistical analysis showed significant differences among the groups. The average number of ganglia containing more than 40 nerve cells $/ \mathrm{cm}^{2}$ is significantly higher in group $\mathrm{B}$ than in group $\mathrm{A}(p<0.01)$ and $\mathrm{C}(p<0.05)$. There are no significant differences among the remaining groups of esophageal segments. Data appear in Tab. 7.

Table 7. Density of ganglia (ganglia $/ \mathrm{cm}^{2}$ ) containing more than 40 nerve cells per ganglion along groups of esophageal segments (A, B, C)

\begin{tabular}{|c|c|c|c|c|c|c|c|}
\hline \multirow{2}{*}{$\begin{array}{l}\text { Groups of } \\
\text { esophageal } \\
\text { segments }\end{array}$} & \multicolumn{6}{|c|}{ Specimen } & \multirow[t]{2}{*}{ Mean \pm SD } \\
\hline & 1 & 2 & 3 & 4 & 5 & 6 & \\
\hline $\begin{array}{l}\text { A ( } 1 \text { to } 3 \mathrm{~cm} \text { above } \\
\text { CI })^{1}\end{array}$ & 15 & 15 & 15 & 4 & 11 & 14 & $12 \pm 4$ \\
\hline $\begin{array}{l}\text { I3 (4 to } 6 \mathrm{~cm} \text { above } \\
\text { CI) }\end{array}$ & 24 & 22 & 23 & 11 & 22 & 23 & $21 \pm 5^{*}$ \\
\hline $\begin{array}{l}\mathrm{C}(7 \text { to } 11 \mathrm{~cm} \text { above } \\
\mathrm{CI})\end{array}$ & 16 & 15 & 18 & 8 & 12 & 20 & $15 \pm 4$ \\
\hline
\end{tabular}

1 Cr Cardiac incisura; * Greater than group $\mathrm{A}(\mathrm{p}<0.01)$ and group $\mathrm{C}(\mathrm{p}<0.05)$.

\section{Discussion}

In order to ensure a minimum influence of technical factors upon results some special cautions were taken. In dissection, the muscle layers were carefully separate. so as to leave the plexus attached to the intermuscular connective septum. 
The method used allowed an adequate identification of the perikarya of the nerve cells and their distinction, in relation to the satellite cells.

Estimations of cell number were carried out on whole mount preparations; this eliminated embedding and sectioning of the tissues, which are responsible for some of the difficulties in counting neurons.

The innervation of the sphincteric regions is generally more dense than that of other regions (Dos Santos 1931, Palumbi 1933, Indar Jit 1955, 1956, Damiani and Battistelli 1956, Ferraz de (ARvalho et al. 1983). The present investigation has shown in the human esophagus, that the mean number of ganglia/ $\mathrm{cm}^{2}$, specialy ganglia containing more than 40 nerve cells per ganglion, and the number of nerve cells $/ \mathrm{cm}^{2}$ in the region of segments IV, V, VI exceeded that in segments I, II, III and that in segments VII to XI. Therefore, density of perikarya and ganglia declined along the distal end of the esophagus with a nadir at the last $3 \mathrm{~cm}$. These results are similar to that obtained for the opossum esophagus (Christexsex and Robisos 1982).

As regards to the higher neuronal concentration observed at the segments 4,5 , and $6 \mathrm{~cm}$ above the cardiac incisura, its functional significance can only be given by further studies, experimental and physiological.

\section{Acknowledgements}

This work was supported by Research Grants from Fundaçao de Amparo a Pesquisa do Estado de Săo Paulo (86/2924-6) and Conselho Nacional de Desenvolvimento Cientifico e Tecnólogico (303916/86-B.Y-F $L^{\top}$ and 407371-87) to R.R.S.

\section{References}

Cecio, A., G. Catifano and R. Lobelio: Further histophysiological observation on the lower esophagus of the rabbit. Cell Tiss. Res. 168 (1976) 475-488.

Christensen, J.: The innervation and motility of the esophagus. Front. Gastrointest. Res. 3 (1978) 18-32.

- and B. A. RoBıson: Anatomy of the myenteric plexus of the opossum esophagus. Gastroenterology 83 (1982) 1033-1042.

Damiani, R., ed U. F. Battistelis: Studio sullo svilluppo embriologico del sistema nervoso intramurale dell esofago. Arch. Ital. Anat. Embriol. 61 (1956) 253-277.

Didio, L. J. A., and M. C. Anderson: The "Sphincters" of the Digestive System. Baltinore: Williams \& Wilkins, 1968.

Dos SANtos, E. M.: L'innervation gastrique et la termination abdominale des pneumogastriques. Folia anat. Coimbra 6 (1931) 1-32.

EскаRdt, V. F., and P. M. LeCompte: Esophageal ganglia and smooth muscle in the elderly. Digest. Dis. 23 (1978) 443-448.

Ferraz de Carvalho, C. A., R. R. de Souza, C. A. Oliveira, G. S. Hamada and P. M. PegoFERnANDEs: A quantitative study on the myenteric plexus of the distal end of the duodenum and the proximal part of the jejunum. Gegenbaurs morph. Jahrb. 129 (1983) 51-56.

INDAR, JiT, I.: The development of the nerve supply of the human oesophagus and stomach. J. anat. Soc. India 4 (1955) 55-68.

- The structure and development of the ileocolic valve and its frenula. India J. med. Res. 44 (1956) 361-373. 
Kadanoff, D., und T. Spassova: (ber die Formen der Ganglienzellen in den intramuralen Geflechten der Speiseröhre beim Menschen. Acta neuroveget. 20 (1959) 19-32.

Koberle, F., R. Brito Costa, J. A. Oliveira e J. S. M. Oliveira: Patologia da molestia de Chagas. Rev. Hosp. Clin. Fac. Med. Ribeirão Preto 1 (1972) 5-45.

Palumbi, G.: Differenti aspetti del plesso di Auerbach in regione dei vari segmenti dell' intestino humano. Ric. Morf. 13 (1933) 538-562.

Snenecor, G. W., and W. G. Cochran: Statistical Methods. Gth ed. Ames (IA): Iowa State University Press 1967 .

Stöнr, jr., P.: Mikroskopische Studien zur Innervation des Magen-Darm-Kanales. Z. Zellforsch. 12 (1930) 66-154.

Virlfam , F.: Sur la présence normale chez l'homme adult d'une valvule musculaire au voisinage de l’angle duodéno-jéjunal. C.R. Ass. Anat., Paris 13 (1911) (iś-i3.

Dr. Roste: R. DE: Sotza,

Departamento de. Anatomia,

Inst ituto de Ciencias Bionedicas da

Inisersidade de Süs Paulos.

Cidade l'niversitária,

Brasil - (1.5.5)ห Sìn Paulos (SP) 


\section{TRABALHO VII}




\title{
MYENTERIC NEURON NUMBER AND SIZES AND GANGLIONIC CONNECTIVE TISSUES IN AGED GUINEA PIG COLON
}

\author{
(LIBERTI, E.A.; ALVES, N.; MINARELLI, A.M.; DE-SOUZA, R.R.)
}

\begin{abstract}
1- The neurons of the myenteric plexus of the entire colon were stained in young adult (3-4 mo old) and aging guinea pigs (36 mo old). Total lenght and circumference of the intestine were measured in the same experiments.

2- The spatial density of myenteric neurons per unit of serosal surface fell dramatically in aging animals, and the mean of total number of myenteric neurons in the colon was only $46 \%$ of the value obtained in young adult guinea pigs.

3- Most of the myenteric neurons in aging guinea-pigs had an irregular and horny appearance in contrast with the smooth-surfaced neurons of young animals.

4- A true ganglionic capsule was absent in both young and aged guinea-pigs. At the ultrastructural level, few collagen fibrils were observed around the neurons.
\end{abstract}

Key words: Myenteric plexus, Autonomic nervous system, Connective tissue, Aging 


\section{INTRODUCTION}

The effects of aging upon mienteric ganglia were described in diverse regions of the human gastrintestinal iract (CAVAZZANA \& BORSETTO, 1948; LORENZ, 1962; KÖBERLE, 1962; ECKARDT \& LeCOMPTE, 1978) and in many kind of animals (ALI \& McLELLAND, 1980; GABELLA, 1987; BAKER \& SANTER, 1988)

Significant reductions of at least $34 \%$ in the number of neurons in the ganglia of the myenteric plexus were recorded in all regions of the human small intestine especially in the duodenum where the number of neurons decreased by over 38\% (DE SOUZA et al., 1993), and in the esophagus where MECIANO FILHO et al. (1995) observed a reduction of $51 \%$ in its upper part. Moreover, the fall in the number of myenteric neurons of the small intestine in aging guinea-pigs was estimated by GABELLA (1989) as only $40 \%-60 \%$ of the value obtained in young adults animals and SANTER \& BAKER (1988) observed silimar reductions in the small and large intestines of aging rats.

In view of these observations it was of interest to see whether a substantial loss of neurons occurred in the guinea-pig colon once that constipation is a common complaint in the elderly (ROBERTS et al., 1994) and myenteric plexus disfunction may partially account for changes in gut motility and transit in elderly persons with constipation (HARARI et al., 1993).

\section{MATERIALS and METHODS}

Seven female guinea pigs aged 6 mo (GI) and seven aged 30-36 mo (GII), were used. The animals were maintained in a special room at the DTAEP-FMUSP biotery where they had been fed ad libitum with diet of dry pellets, hay, and water.

The estimates of neuronal density and total number of neurons in the myenteric plexus of the colon were obtained in four animals from both GI and GII aging by using the procedure described by GABELLA (1969). Briefly, the animals were killed with an overdose of anesthetic, and the colon was excised and placed in a Krebs' solution (at room temperature) of the following composition $(\mathrm{mM}): \mathrm{Na}^{+}, 137.4 ; \mathrm{K}, 5.9 ; \mathrm{Ca}^{2+}, 2.5 ; \mathrm{Mg}^{2+}, 1.2$; $\mathrm{Cl}^{-}, 134 ; \mathrm{HCO}_{3}^{-}, 15.5 ; \mathrm{H}_{2} \mathrm{PO}_{4}^{-}, 1.2$; glucose, 11.5. The colons were then ligated with cotton thread at either end and gently distended with Krebs'solution, introduced by a syringe at one end. After sufficient distension, the syringe needle was withdrawn and the ligature 
simultaneously tightened. After been rinsed for a few minutes in fresh Krebs' solution, the intestine was incubated for detection of $\beta$-nicotimamide adenine dinucleotide (NADH) reductase. The inedium was made by mixing 25 parts of a $0.5 \mathrm{mg} / \mathrm{ml}$ stock solution of Nitro Blue Tetrazolium (Sigma) in distilled water, 25 parts of a $0.1 \mathrm{M}$ sodim phosphate buffer at

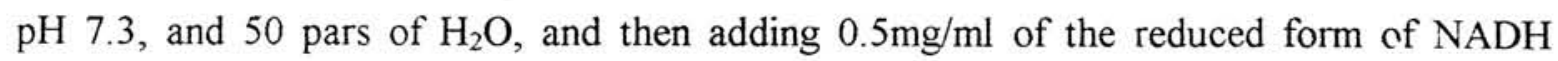
(Sigma). A preincubation rinse for $60-100 \mathrm{~s}$ in a detergent solution $(0.3 \%$ Triton $\mathrm{X}-100$ in Krebs' solution) was used to increased penetration of the medium into the intestinal wall and consistency of staining. The development of the reaction was controlled visually under a dissecting microscope and was stopped after 60-70 min by transferring the colons into fixative ( $10 \%$ formaldeyde in phosphate buffer). The length colons were measured in the fixed and fully distended preparation. Five segments with approximately $3 \mathrm{~cm}$ length were obtained from each colon as follows: from the middle part of the colon (M), immediatelly after the cecum (P), immediatelly before the rectum (D), equidistant from $\mathrm{P}$ and $\mathrm{M}$ segments (PI) and equidistant from $\mathrm{P}$ and D segments (DI). Whole mount preparations of the myenteric plexus were made from these segments. Tunica serosa, longitudinal muscle, myenteric plexus, and part of the circular muscle were lifted as a lamina by dissection with watchmaker's tweezers. The laminae were washed in several changes of distilled water and were mounted in a $50 \%$ solution of glycerol in distilled water. The neurons present in fifty aleatory fields of each region from each animal were counted under the microscope at a magnification of $400 \mathrm{X}$.

The profiles of 50 nerve cell perikarya for each segment of each animal were outlined and analyzed using a semi-automatic image analyzer (MINI-MOP KONYTRN BILDANALYSE) with a camera lucida attached to the microscope.

The results were analyzed by analysis of variance $(\mathrm{P}=0.05)$ followed by the Tukey multiple means test $(\mathrm{P}=0.05)(\mathrm{ZAR}, 1984)$.

Three animals from GI and GII were used for a separate ultrastructural study of the ganglionic conective tissue. Fixation was performed by intravascular perfusion of $4 \%$ glutatraldehyde (in $0.1 \mathrm{M}$ phosphate buffer, $\mathrm{pH}$ 7.2) for $10 \mathrm{~min}$. The abdomen was opened and small tissue were dissected out fron diverse regions of the colon. The specimens were post-fixed in phosphate-buffered $(0.1 \mathrm{M})$ OsO4-solution $(1 \%)$ for 2 hours, dehydrated with 
ethanol's and embedded in Araldite. Thin sections were stained with lead citrate and uranyl acetate. Electron micrographs were taken on a Philips EM 301.

\section{RESULTS}

By comparison with the plexus in GI and GII, the myenteric plexus of aging animals had fewer neurons per unit surface and the neurons were markedly less densely packed with many of them with an irregular and horny profile (Fig. 1)

The neuronal density in GII ranged from 16.900 to 22.700 neurons $/ \mathrm{cm}^{2}$ of serosal surface (mean: 18.905,0 neurons $/ \mathrm{cm}^{2}$; SD: $2.697,5$ ), a value markedly smaller than that obtained from GI where the neuronal density ranged from 31.360 to 64.620 neurons $/ \mathrm{cm}^{2}$ with mean of $53.397,5$ neurons $/ \mathrm{cm}^{2}$; SD $15.300,5$ (Table 1).

The total number of myenteric neurons in the colon of GI ranged between 5.7 and 8.7 million (average 6.9 million) and in the colon of GII these values ranged between 3.1 and 3.4 million (average 3.2 million) (Table 2).

The ranges of perikaryon size, expressed as perikaryon area are shown in Figure 2 and the mean ( \pm Standard Deviation) of perikaryon size from each region of both GI and GII are shown in Table III.

The ganglionic capsule and the septa inside the ganglion were not developed in both GI and GII guinea-pigs. Only few collagen fibrils were observed surrounding the ganglia and they were dispersed between the neurons (Fig. 3).

\section{DISCUSSION}

According to GABELLA (1989), the total number of neurons within the gut of a given species is extremely high and the vastness of the enteric neuronal population attests to the importance that the fine tuning of intestinal motility and secretory activity has had for the survival of a species.

The present investigation has shown that the number of myenteric neurons in the colon of aging guinea pigs is only about half that found in young adult guinea pigs being the loss of myenteric neurons probably due to nerve cell death (GABELLA, 1989).

SANTER \& BAKER (1988) observed reductions of $40 \%-60 \%$ of the number of neurons on the myenteric plexus of aged rats. They related that there were no differences in 
the distribution of neuron sizes between young and aging animals being that the neuronal loss affected all types of neurons within the ganglia. In the same specie, DUNLAP et al. (1988) observed an increase of the average area of the myenteric ganglia, no change in neuron density per unit area of ganglion, and an increase in length of the small intestine in aging subjects which imply that the number of neurons continues to increase in old age.

The present experiments provide no evidence as to whether this is the case $\mathrm{i}_{\mathrm{i}}$ the guinea pig colon, or whether certain subpopulations of myenteric neurons are affected more than others. However, the neurons with the horny outline that predominate in aging animals are uncommon in the young animals, an observation that leads one to suggest that nerve cell loss is only one of many structural changes occuring in the myenteric plexus of aging guinea pigs.

In aging rats, a vast decrease of adrenergic varicosities in the myenteric ganglia is well documented by quantitative fluorescence microscopy (BAKER \& SANTER, 1988), and a loss of nerve fibers immunoreactive for substance $\mathrm{P}$, vasoactive intestinal polypeptide, or somatostatin (fibers that are mostly of intrinsic origin) is well documented by immunocytochemistry (FEHÉR and PENZES, 1983).

Neither the study by SANTER and BAKER (1988), GABELLA (1989) nor the present one establish whether the loss of neurons occurs over a limited period of time or whether it is spread over a large portion of the life of the animal, and, if the latter is the case, at what age the process begins. However, the loss of neurons in the myenteric plexus is very extensive (GABELLA, 1989).

The loss of neurons might simply eliminate redundant neurons or might result from the increased efficiency of the surviving elements and the anatomic and histologic appearance of the gut suggest the absence of pathological changes in the gut, and reinforce the impression of GABELLA (1989) that the substantial loss of neurons is part of the programmed life history of the myenteric neurons in the guinea pig. These assertives are not corroborated by ohter authors in human once that constipation is a common complaint in the elderly (ROBERTS et al., 1994) and colonic motility dependes on the integrity of many structures as the gut wall innervation and the circular smooth muscle layer. According to HARARI et al. (1993) myenteric plexus disfunction may partially account for changes in gut motility and transit in elderly persons with constipation. 


\section{REFERENCES}

Ali, H.A.; McLellland, J. Variations in neuron size in the avian intestinal myenteric plexus. Anat. Anz., 147:348-353, 1980.

Baker DM, Santer. A quantitative study of the effects of age on the noradrenergic innervation of Auerbacl: s plexus in the rat. Mech Ageing Dev 1988; 42: 147-58.

Cavazzana, P.; Borsetto, P.L. Recherches sur l'aspect microscopique des plexus nerveux intramuraux et sur les modifications morphologiques de leurs neurones dans les divers traits de l'intestin humain pendant la vie. Acta Anat., 5:17-41, 1948.

De Souza, R.R.; Moratelli, H.B.; Borges, N.; Liberti, E.A. Age-induced nerve cell loss in the myenteric plexus of the small intestine in man. Gerontology, 39:183-188, 1993.

Dunlap CE, Mattox H, Nelson JB, Castell DO. Morphometric analysis of enteric neurons in small intestine of the Fischer rat across age. Gastroenterology 1988; 94: A107.

Eckardt, W.F.; Le Compte, P.M. Esophageal ganglia and smooth muscle in the eldery. Dig. Dis., 23:443-448, 1978

Fehér E, Penzes L. Density of substance p, vasoactive intestinal polypeptide and somatostatin-containing nerve fibers in the ageing small intestine of the rats. Gerontology 1987; 33:341-8.

Gabella G. The number of neurons in the small intestine of mice, guinea-pigs and sheep. Neuroscience $1987 ; 22: 737-52$.

Gabella $\mathrm{G}$. Fall in the number of myenteric neurons in aging guinea-pigs. Gastroenterology, 96:1487-1493, 1989.

Harari, D.; Gurwitz, J.H.; Minaker, K.L. Constipation in the elderly. JAGS, 41:1130-1140, 1993.

Köberle, F. Quantitative Pathologie des Vegetativen Nervensystem. Wien. Klin. Wochenschr., 74:144-151, 1962.

Lorenz, J. Observations comparatives sur línnervation intramurale du cardia, du pylore et de valve iléo-coecale chez l'Homme normal au cours de l'âge. Z. Mikrosk. Anat. Forsch. (Leipzig), 68:540-563, 1962. 
Meciano Filho, J; Carvalho. V C.: De Souza, R.R. Nerve cell loss in the myenteric plexus of the human esophagus in relation to age: A preliminarly investigation. Gerontology, 41:18-21, 1995.

Roberts, D.; Gelperin, D.; Wiley, J.W. Evidence for age-associated reduction in acetylcholine release and smooth muscle response in the rat colon. Am. Physiol. Sol., 267:515--522, 1994.

Santer RM, Baker DM. Enteric neuron numbers and sizes in Auerbach's plexus in the small and large intestine of young adult and aged rats. J. Auton Nerv Syst 1988; 25:59-67.

Zar, J.H. Biostatistical Analysis. 2 ed.. N. Jersey, Prentice Hall, 1984. 


\section{FIGURES}

1. a- Large myenteric ganglion from colon of group GI. b- Myenteric ganglion from group GII showing less densely packed neurons with iregular profile. Some glial cells nuclei are observed (arrows).

2. a- Distribution of neuron profile areas in different regions of the colon of young (GI) and aged (GII) guines-pigs.

3. a- Electron micrograph of a myenteric ganglion from group GII. The nucleus of a ganglionic neuron $(\mathrm{N})$ is seen as are adjacent neuronal prolongation (arrows). Few collagen fibrils are observed around the ganglion (Arrowheads). b- A myenteric neuron $(N)$ of a ganglion from group GI. Sparce collagen fibrils are present between the ganglionic neurons (arrows).

Table 1- Neuronal density $\left(\mathrm{N} / \mathrm{cm}^{2}\right)$ in diverse regions of the guinea-pig colon (Mean $\pm \mathrm{SD}$ ).

Table 2- Mean of the total number of neurons in the myenteric plexus of guinea pig colon estimated for both young (GI) and old (GII) subjects (Mean \pm SD).

Table 3- Mean of perikaryon area of the myenteric neurons in diverse regions of the guineapig colon for GII and GII (Mean \pm SD) 

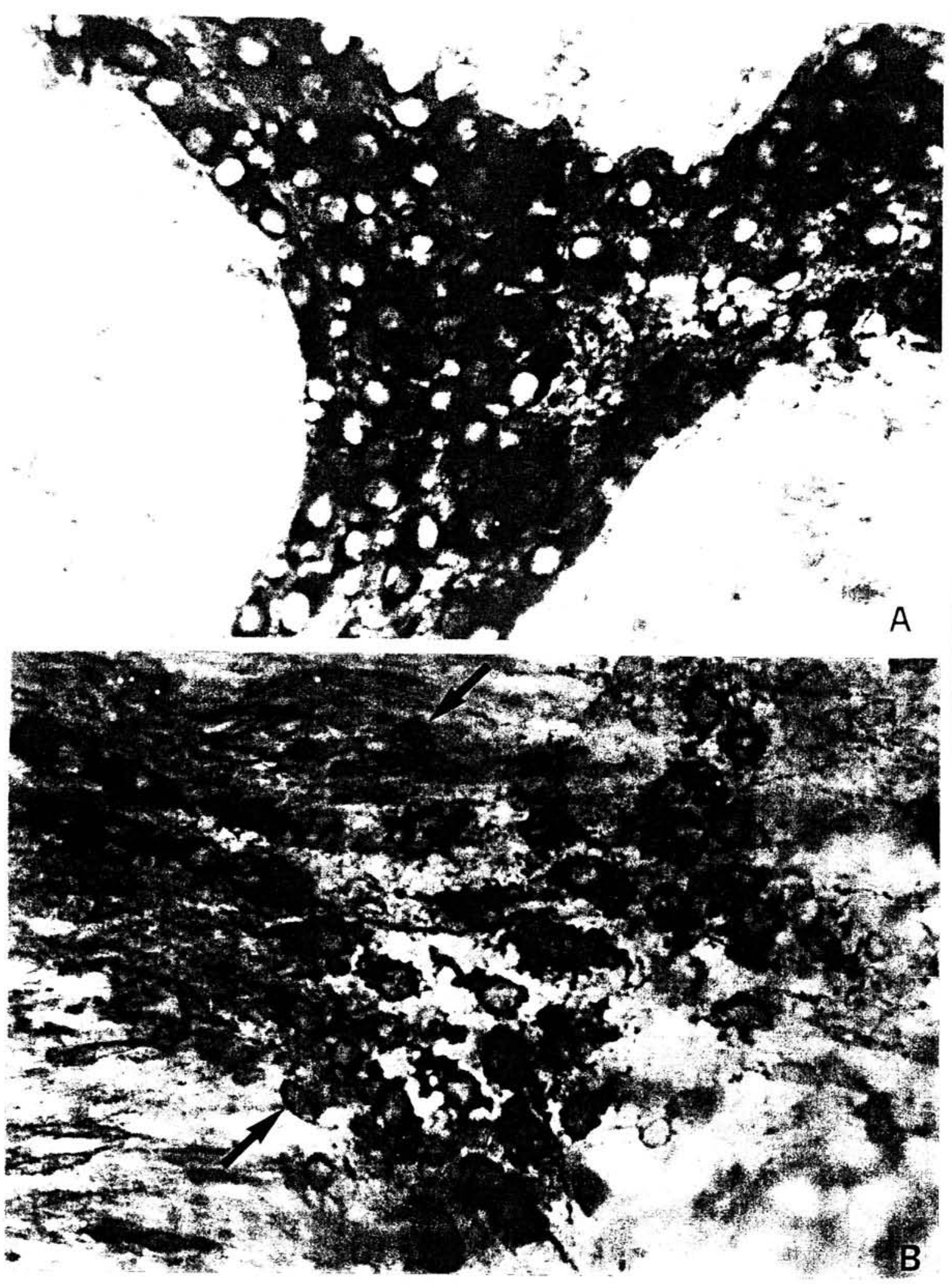
(\%)

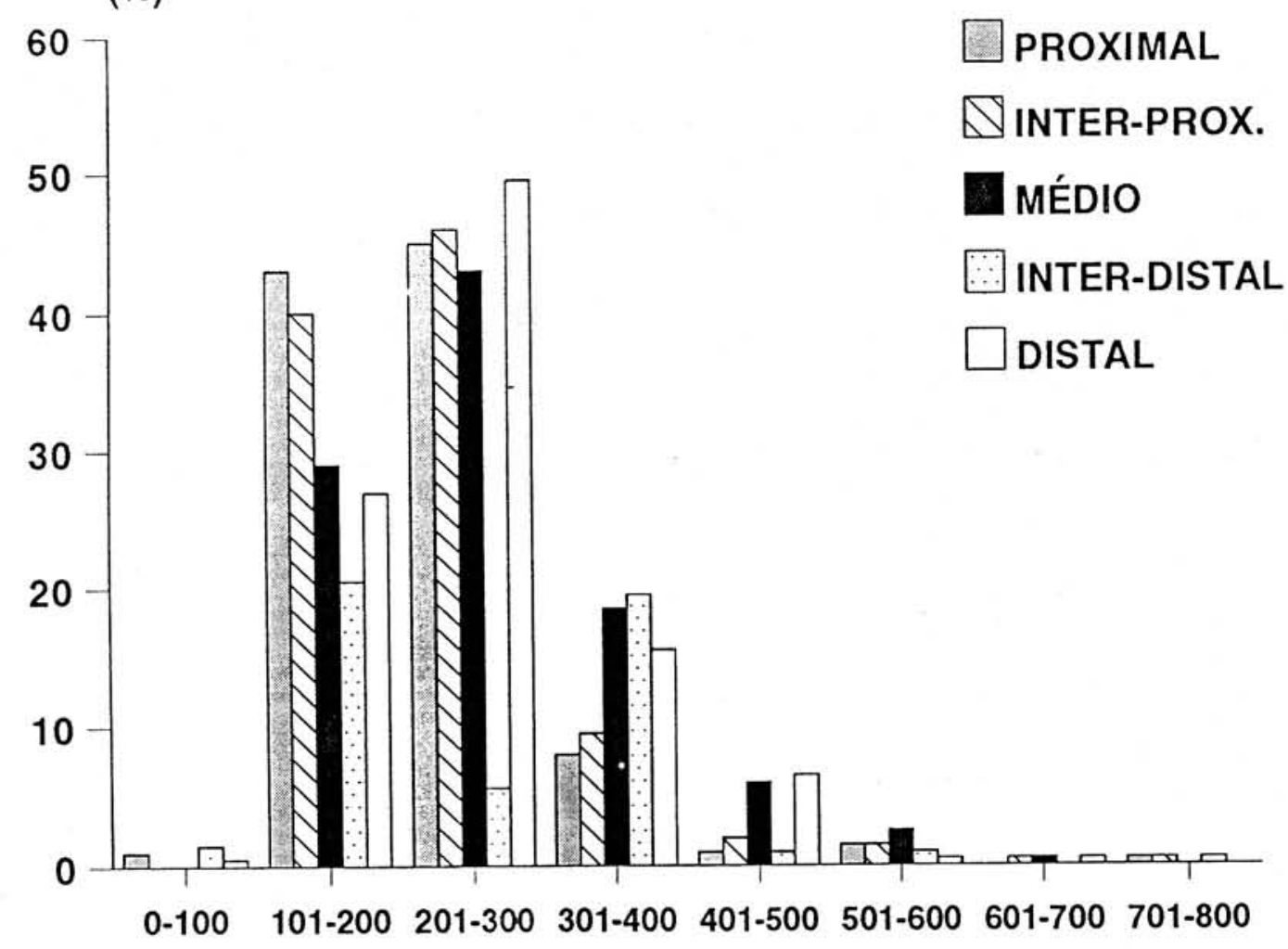

(\%)

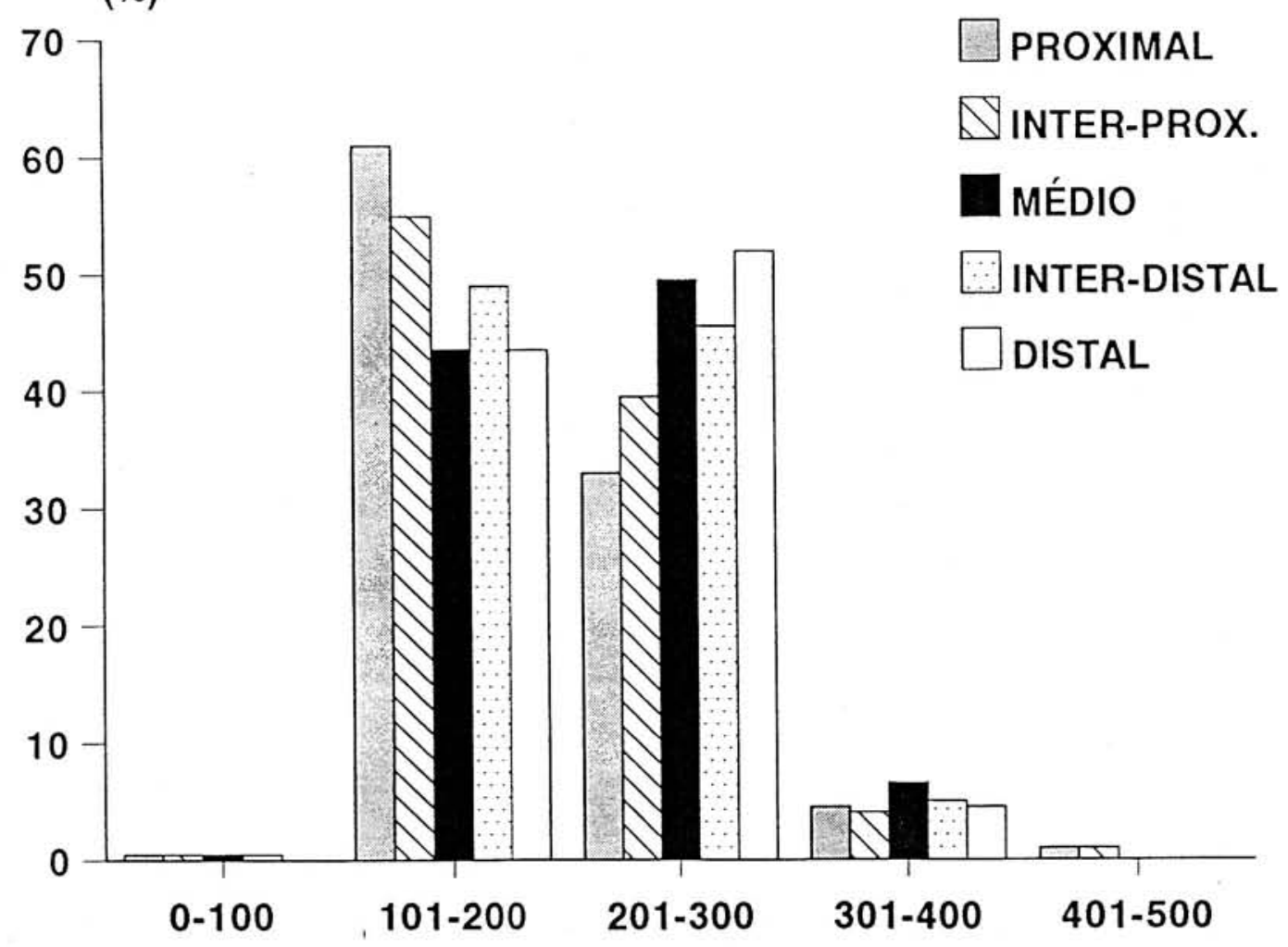




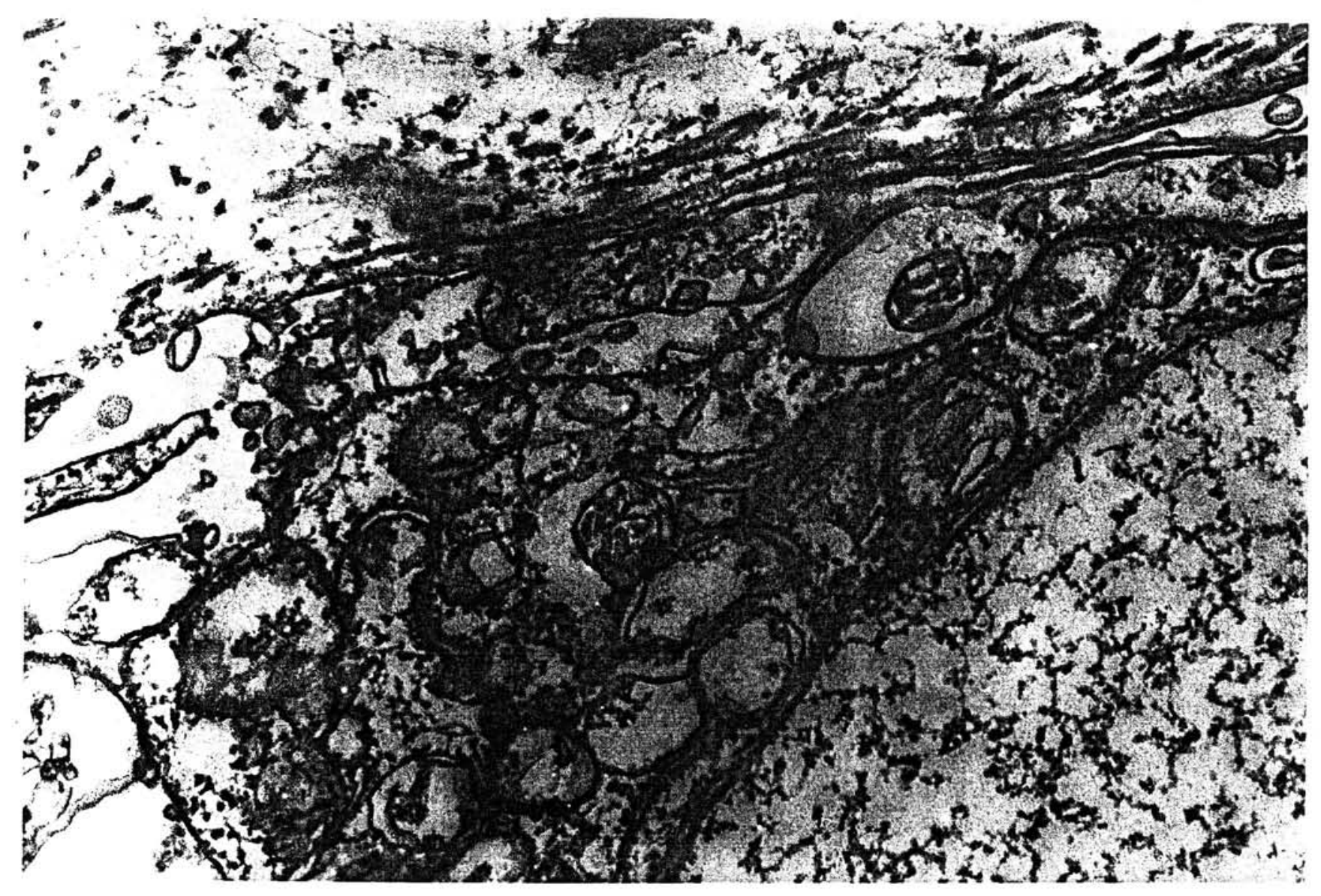

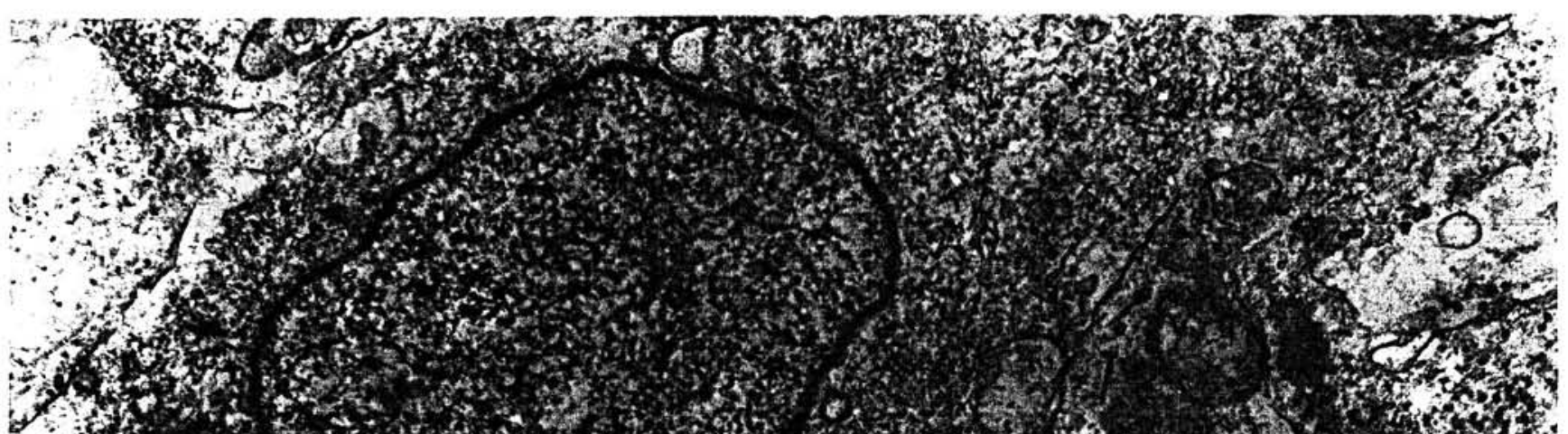
3
3

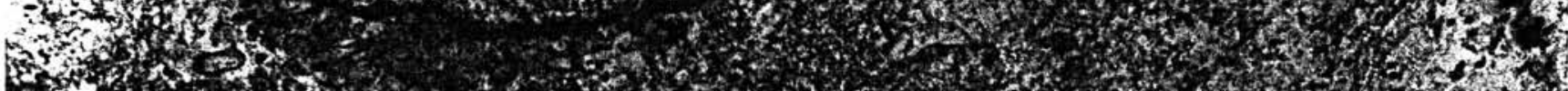

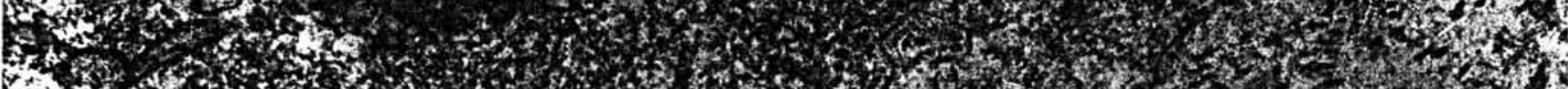

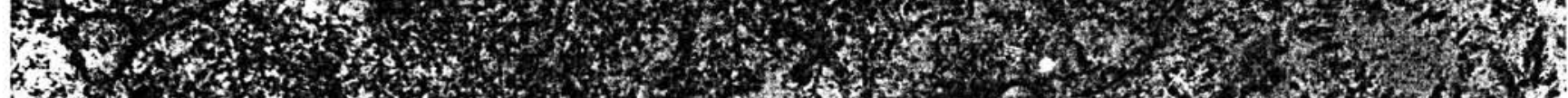

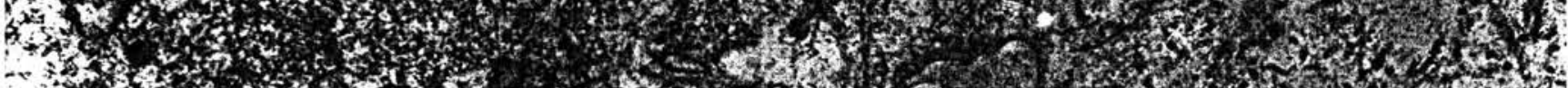

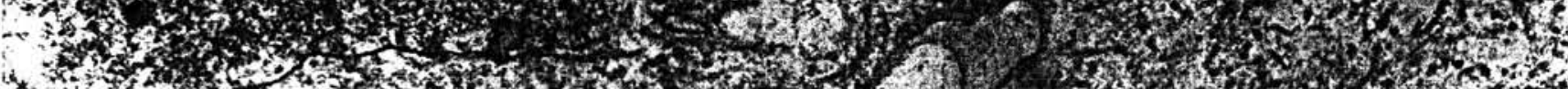

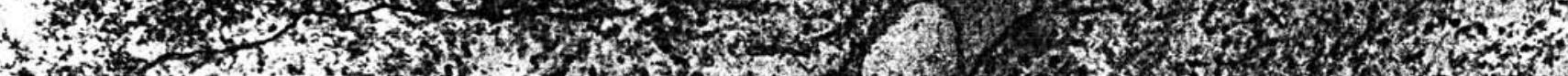

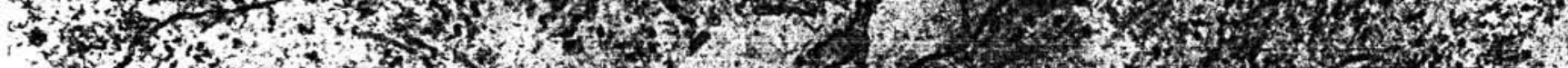

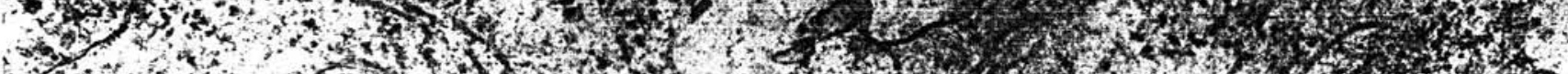

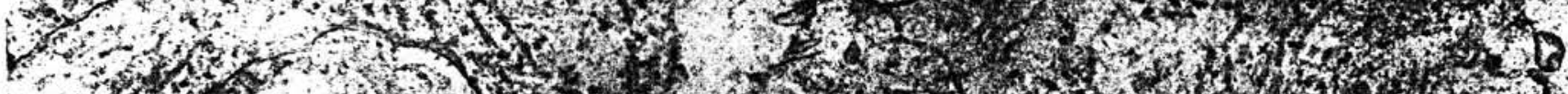

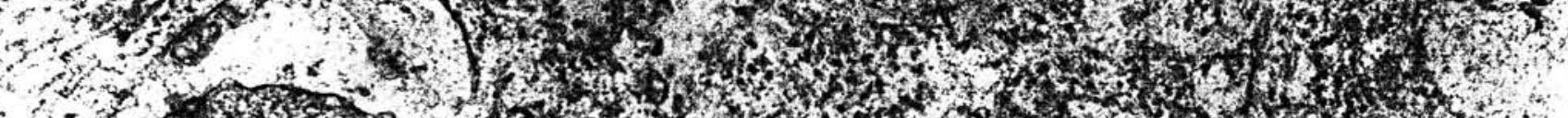

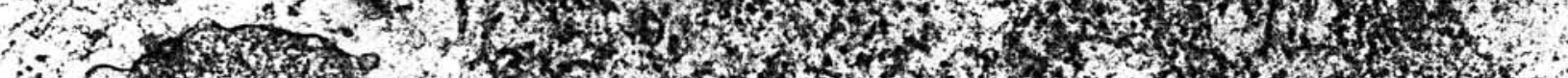
$\therefore$ Sory 


\begin{tabular}{|c|l|l|}
\hline Animais & Grupo Jovem & Grupo Idoso \\
\hline 1 & 31.360 & 17.060 \\
\hline 2 & 54.790 & 16.900 \\
\hline 3 & 64.620 & 18.960 \\
\hline 4 & 62.820 & 22.700 \\
\hline $\bar{X}$ & $53.397,5$ & $18.905,0$ \\
\hline$d p$ & $\pm 15.300,5$ & $\pm 2.697,5$ \\
\hline
\end{tabular}

\begin{tabular}{|c|c|c|}
\hline Caso & Jovem & Idoso \\
\hline 1 & 5.768 .070 & 3.446 .120 \\
\hline 2 & 5.857 .051 & 3.133 .260 \\
\hline 3 & 8.652 .618 & 3.382 .464 \\
\hline 4 & 7.657 .758 & 3.161 .088 \\
\hline $\bar{X}$ & 6.983 .880 & 3.280 .730 \\
\hline$d p$ & \pm 1.412 .650 & \pm 156.806 \\
\hline
\end{tabular}

\begin{tabular}{|c|c|c|}
\hline & Jovem & Idoso \\
\hline P & $225,98 \pm 32,09$ & $195,58 \pm 23,50$ \\
\hline IP & $228,14 \pm 38,28$ & $201,21 \pm 12,37$ \\
\hline M & $265,15 \pm 38,97$ & $212,28 \pm 8,98$ \\
\hline ID & $255,06 \pm 18,86$ & $208,20 \pm 13,65$ \\
\hline D & $255,60 \pm 45,60$ & $210,22 \pm 15,53$ \\
\hline
\end{tabular}




\section{TRABALHO VIII}




\section{ESTUDO COMPARATIVO DOS GÁNGLIOS DO PLEXO MIENTÉRICO DO ESÔFAGO, ESTÔMAGO, INTESTINO DELGADO E COLO HUMANOS.}

(GASPAR, L.P.; DE SOUZA, R.R.; LIBERTI, E.A.)

\section{INTRODUÇÃO}

Incluídos nas paredes do tubo digestivo, os plexos nervosos entéricos são estruturas bem desenvolvidas, cujas funções se relacionam com a regulação da atividade secretória e propulsiva do conteúdo do trato gastrintestinal, tornando seu estudo importante para a compreensão da fisiologia normal e patologias que acometem essas vísceras.

Distingue-se dois tipos de plexos entéricos: o plexo mientérico, entre as túnicas musculares longitudinal externa e circular interna, e o plexo submucoso, na tela submucosa.

Particularmente em relação ao plexo mientérico, verifica-se que o mesmo é composto por uma rede de feixes nervosos e gânglios situados nas interconexões de suas malhas, contendo corpos celulares de neurônios e células satélites. $\mathrm{O}$ padrão morfológico dos gânglios e dos corpos celulares variam segundo a espécie e a localização no trato gastrointestinal (GABELLA, 1981; GABELLA \& TRIGG, 1984).

No presente trabalho procuramos determinar a área do perfil celular dos neurônios presentes nos gânglios do plexo mientérico do esôfago, estômago, duodeno e colo sigmóide humanos, bem como analisar os componentes fibrosos colágeno e elástico ganglionares de individuos normais. Tais observações servirão de base importante para se avaliar os efeitos 
de diversos agentes modificadores da fisiologia normal do plexo mientérico, tais como o envelhecimento e a moléstia de Chagas.

\section{MATERIAIS E MÉTODOS}

\subsection{Morfologia e área do perfil celular dos corpos dos neurônios}

Estão sendo utilizados para este estudo seis esôfagos, seis estômagos, seis duodenos e seis colos sigmóides, obtidos no Serviço de Verificação de Óbitos do Hospital das Clínicas da Faculdade de Medicina da Universidade de São Paulo.

De cada uma das peças foram retirados segmentos anulares de $2 \mathrm{~cm}$ da seguinte maneira:

-esôfago: um segmento obtido da extremidade oral do órgão cuja borda superior é a seç̧ão limitante ao nível da borda inferior da parte cricofaríngea do músculo constrictor inferior da faringe; um segmento demarcado a $5 \mathrm{~cm}$ abaixo da borda inferior do primeiro segmento; um segmento obtido da extremidade aboral do esôfago, cuja borda inferior corresponde ao nível da incisura cárdica e um um segmento demarcado a $5 \mathrm{~cm}$ acima da borda superior do segmento anterior.

-estômago: um segmento da região mais cranial do fundo; quatro segmentos do corpo, sendo um trecho da curvatura menor ( $2 \mathrm{~cm}$ acima da incisura angular), um da curvatura maior, a meia distância entre o fundo e o antro pilórico, um da parte anterior, na região central da parede anterior, um da parede posterior, na região central; um da parede anterior do antro, entre a incisura angular e o piloro gastroduodenal e um da parede posterior, entre a incisura angular e o piloro; 
-intestino delgado: um segmento da região situada a $4 \mathrm{~cm}$ a montante da flexura duodeno-jejunal;

-intestino grosso: um segmento da parte média do colo sigmóide.

Após a retirada dos segmentos, os mesmos foram abertos longitudinalmente, lavados com solução salina, distendidos discretamente e fixados por meio de alfinetes em 'placas de cera com a mucosa voltada para cima e colocados em solução fixadora constituída de $3 \mathrm{ml}$ de formaldeído $35 \%, 1,5 \mathrm{ml}$ de ácido acético, 0,9g de $\mathrm{NaCl}$ e $100 \mathrm{ml}$ de $\mathrm{H}_{2} \mathrm{O}$ (BARBOSA, 1978), por um período de 2 horas.

Decorrido esse tempo, as túnicas mucosa e submucosa foram retiradas sob microscópio estereoscópico (6 a 60X) com o auxilio de pinças de cirurgia oftalmológica e utilizando-se de epi-iluminação, quando então procedeu-se à retirada de fibras musculares das camadas mais superficiais do extrato interno.

As membranas obtidas nessa etapa foram novamente presas com alfinetes em placas de cera e colocadas na mesma solução fixadora, aí permanecendo por um período de 24 horas.

A seguir, as membranas foram transferidas para a solução corante de Giemsa modificada (BARBOSA, 1978) onde permaneceram por um período de 24 horas.

Após essa etapa, procedeu-se à desidratação dos preparados totais de membrana em série crescente de álcoois (4 passagens de cerca de 3 minutos cada) e diafanização através de 3 passagens em xilol, com duração de 10 minutos cada.

A seguir, as membranas foram novamente dissecadas sob estereomicroscópio (6 a $60 \mathrm{X})$, com o auxílio de pinças oftalmológicas para que fosse retirado o maior número possivel de fibras musculares da camada circular, tomando-se o máximo de cuidado para 
não lesar o plexo mientérico que, de acordo com a tecnica empregada deveria permanecer visível durante todo o tempo da micro-dissecção.

Cada membrana obtida foi, a seguir, montada entre lâmina e lamínula em resina sintética (Entellan-Merck), mantendo-se a lamínula sob pressão através de um peso metálico por um a dois dias, para evitar a formação de bollias de ar no preparado.

Foram determinados os contornos de 560 neurônios de cada região, escolhidos de maneira aleatória, obtido através de um processador de imagens semi-automático (MiniMop Kontron Bildanalyse) com uma câmara clara acoplada a um microscópio de luz binocular $(500 \mathrm{X})$. Os dados foram comparados estatisticamente pela análise de variância seguida pelo teste de Tukey $(\mathrm{P}=0.05)(\mathrm{ZAR}, 1989)$.

\section{RESULTADOS}

Os resultados obtidos pela análise dos preparados de membrana mostraram-se eficientes para o estudo do plexo mientérico do tubo digestivo humano; realizou-se facilmente a dissociação dos dois estratos de músculo liso, permitindo uma boa visualização dos gânglios e neurônios.

As membranas foram coradas e diafanizadas de forma adequada e uniforme, sendo que as células nervosas coraram-se mais intensamente que as células musculares, o que facilitou sua visualização e delimitação com boa definição.

\subsection{Dimensões da área da imagem do corpo celular.}

As dimensões da área da imagem do corpo celular dos neurônios do plexo mientérico em projeção bidimensional de todas as regiões não formam uma população 
homogenea, variando dos intervalos de 62,50 a $1406,25 \mu \mathrm{m}^{2}$ para o esôfago, 31,25 a $1015.63 \mathrm{~mm}$ para o estomago, para o duodeno de 31,25 a $937,50 \mu \mathrm{m}^{2}$ e para o colo sigmóide, de 15,63 a 656,25 $\mu \mathrm{m}^{2}$ (Tabelas I - IV).

A análise dos histogramas da distribuição das dimensões da área da imagem do corpo celular nas regiões abordadas demonstrou que a maior freqüência no esôfago foi observada no intervalo de 300 a $500 \mu \mathrm{m}^{2}$, de 100 a $400 \mu \mathrm{m}^{2}$ no estômago, ede de 100 a $300 \mu \mathrm{m}^{2}$ no duodeno e no colo sigmóide.(Figs. 1 -4). As áreas médias dos corpos neuronais foram de $489,97 \pm 212,35 \mu \mathrm{m}^{2}$ para o esôfago, $284,77 \pm 134,70 \mu \mathrm{m}^{2}$ para o estômago, 291,39 $\pm 157,86 \mu \mathrm{m}^{2}$ para o duodeno e $241,64 \pm 122,62 \mu \mathrm{m}^{2}$ para o colo sigmóide. 


\begin{tabular}{|c|c|c|}
\hline ÁREA $\left(\boldsymbol{\mu m}^{2}\right)$ & NEURÔNIOS & $\%$ \\
\hline $\mathbf{0 - 1 0 0}$ & 5 & 0,89 \\
\hline $\mathbf{1 0 1 - 2 0 0}$ & 35 & 6,25 \\
\hline $\mathbf{2 0 1 - 3 0 0}$ & 51 & 9,11 \\
\hline $\mathbf{3 0 1 - 4 0 0}$ & 115 & 20,54 \\
\hline $\mathbf{4 0 1 - 5 0 0}$ & 122 & 21,79 \\
\hline $\mathbf{5 0 1 - 6 0 0}$ & 72 & 12,86 \\
\hline $\mathbf{6 0 1 - 7 0 0}$ & 56 & 10,00 \\
\hline $\mathbf{7 0 1 - 8 0 0}$ & 61 & 10,89 \\
\hline$>800$ & 43 & 7,67 \\
\hline TOTAL & 560 & 100,00 \\
\hline
\end{tabular}

\begin{tabular}{|c|c|c|}
\hline ÁREA $\left(\boldsymbol{\mu m}^{2}\right)$ & NEURÔNIOS & $\%$ \\
\hline $\mathbf{0 - 1 0 0}$ & 27 & 4,82 \\
\hline $\mathbf{1 0 1 - 2 0 0}$ & 129 & 23,04 \\
\hline $\mathbf{2 0 1 - 3 0 0}$ & 180 & 32,14 \\
\hline $\mathbf{3 0 1 - 4 0 0}$ & 133 & 23,75 \\
\hline $\mathbf{4 0 1 - 5 0 0}$ & 46 & 8,21 \\
\hline $\mathbf{5 0 1 - 6 0 0}$ & 31 & 5,54 \\
\hline $\mathbf{6 0 1 - 7 0 0}$ & 9 & 1,61 \\
\hline $\mathbf{7 0 1 - 8 0 0}$ & 4 & 0,71 \\
\hline$>\mathbf{8 0 0}$ & 1 & 0,18 \\
\hline TOTAL & 560 & 100,00 \\
\hline & & \\
\hline
\end{tabular}




\begin{tabular}{|c|c|c|}
\hline ÁREA $\left(\boldsymbol{\mu m}^{2}\right)$ & NEURÔNIOS & $\%$ \\
\hline $\mathbf{0 - 1 0 0}$ & 37 & 6,61 \\
\hline $\mathbf{1 0 1 - 2 0 0}$ & 144 & 25,71 \\
\hline $\mathbf{2 0 1 - 3 0 0}$ & 160 & 28,57 \\
\hline $\mathbf{3 0 1 - 4 0 0}$ & 98 & 17,50 \\
\hline $\mathbf{4 0 1 - 5 0 0}$ & 47 & 8,39 \\
\hline $\mathbf{5 0 1 - 6 0 0}$ & 47 & 8,39 \\
\hline $\mathbf{6 0 1 - 7 0 0}$ & 21 & 3,75 \\
\hline $\mathbf{7 0 1 - 8 0 0}$ & 2 & 0,36 \\
\hline$>\mathbf{8 0 0}$ & 4 & 0,72 \\
\hline TOTAL & 560 & 100,00 \\
\hline
\end{tabular}

\begin{tabular}{|c|c|c|}
\hline ÁREA $\left(\boldsymbol{\mu m}^{2}\right)$ & NEURÔNIOS & $\%$ \\
\hline $\mathbf{0 - 1 0 0}$ & 46 & 8,21 \\
\hline $\mathbf{1 0 1 - 2 0 0}$ & 184 & 32,86 \\
\hline $\mathbf{2 0 1 - 3 0 0}$ & 178 & 31,79 \\
\hline $\mathbf{3 0 1 - 4 0 0}$ & 85 & 15,78 \\
\hline $\mathbf{4 0 1 - 5 0 0}$ & 46 & 8,21 \\
\hline $\mathbf{5 0 1 - 6 0 0}$ & 11 & 1,96 \\
\hline $\mathbf{6 0 1 - 7 0 0}$ & 10 & 1,79 \\
\hline TOTAL & 560 & 100,00 \\
\hline
\end{tabular}


$\operatorname{ÁREA}\left(\mu \mathbf{M}^{2}\right)$

\begin{tabular}{|c|c|c|c|}
\hline DUODENO & ESÔFAGO & COLO & ESTÔMAGO \\
\hline $291.39 \pm 157.86$ & $489.97 \pm 212.35$ & $241.64 \pm 122.62$ & $284.77 \pm 134.70$ \\
\hline
\end{tabular}

ANÁlise Estatística:

A suposição de homocedasticidade dos grupos não foi satisfeita nem com transformação nos dados. Empregou-se análise de variância não-paramétrica - Kruskal-Wallis, seguida por comparações múltiplas. O nível de significância adotado foi $\mathrm{p}<0.05$.

\section{ConClusóes:}

1. Existe diferença significante entre as REGIÕES, $\mathrm{p}=0.000$ :

- no ESÔFAGO observou-se maior área do que nas demais REGIÕES, $\mathrm{p}<0.05$;

- no COLO observou-se menor área que nas demais REGIÕES; $p<0.05$;

- no DUODENO e no ESTÔMAGO observou-se a mesma área, p>0.05. 
Legendas

Figura 5-a- Gânglio do plexo mientérico do esôfago humano; b- Gânglio do plexo mientérico do estômago humano; c- Gânglio do plexo mientérico do duodeno humano; dGânglio do colo sigmóide humano. (Giemsa, a-d- 220X).

Tabela I - Distribuição dos neurônios do plexo mientérico do esôfago humano classificados segundo a área do corpo celular.

Tabela II- Distribuição dos neurônios do plexo mientérico do estômago humano classificados segundo a área do corpo celurlar.

Tabela III- Distribuição dos neurônios do plexo mientérico do duodeno humano classificados segundo a área do corpo celular.

Tabela IV- Distribuição dos neurônios do plexo mientérico do colo sigmóide humano classificados segundo a área do corpo celular. 
Distribuição dos neurônios do plexo mientérico do esôfago de acordo com a área da imagem do corpo celular

(\%)

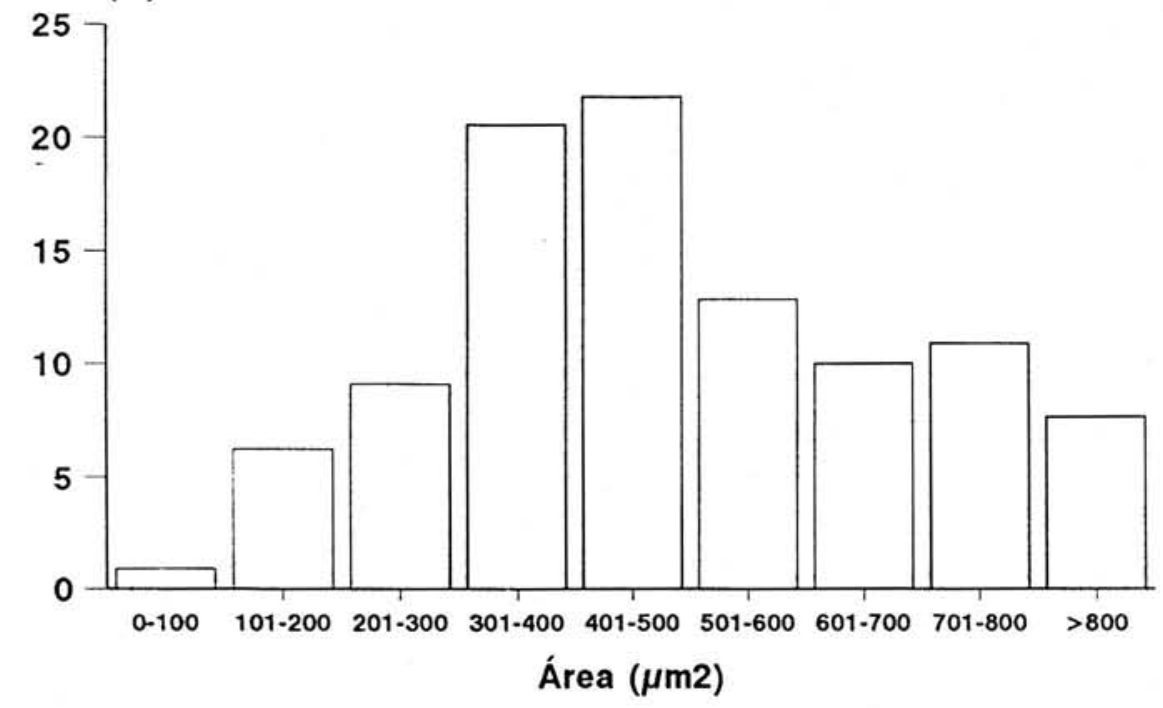

Distribuição dos neurônios do plexo mientérico do estômago de acordo com a área da imagem do corpo celular

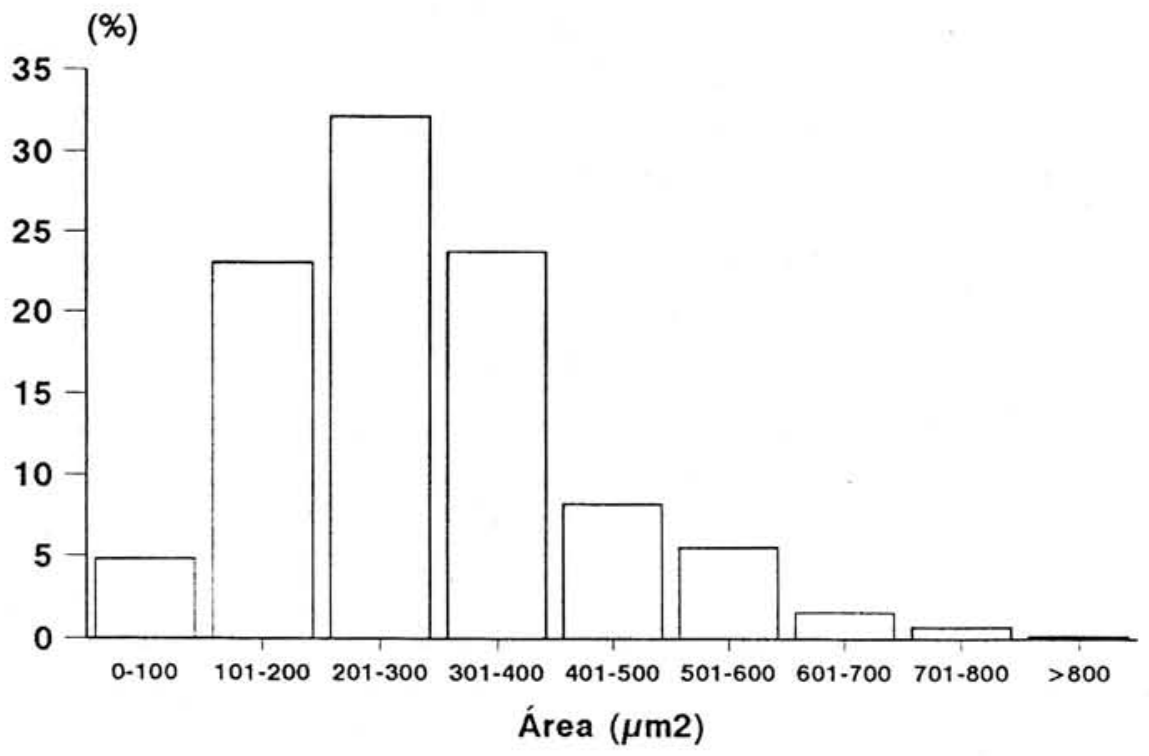


Distribuição dos neurônios do plexo mienterico do duodeno de acordo com a área da imagem do corpo celular

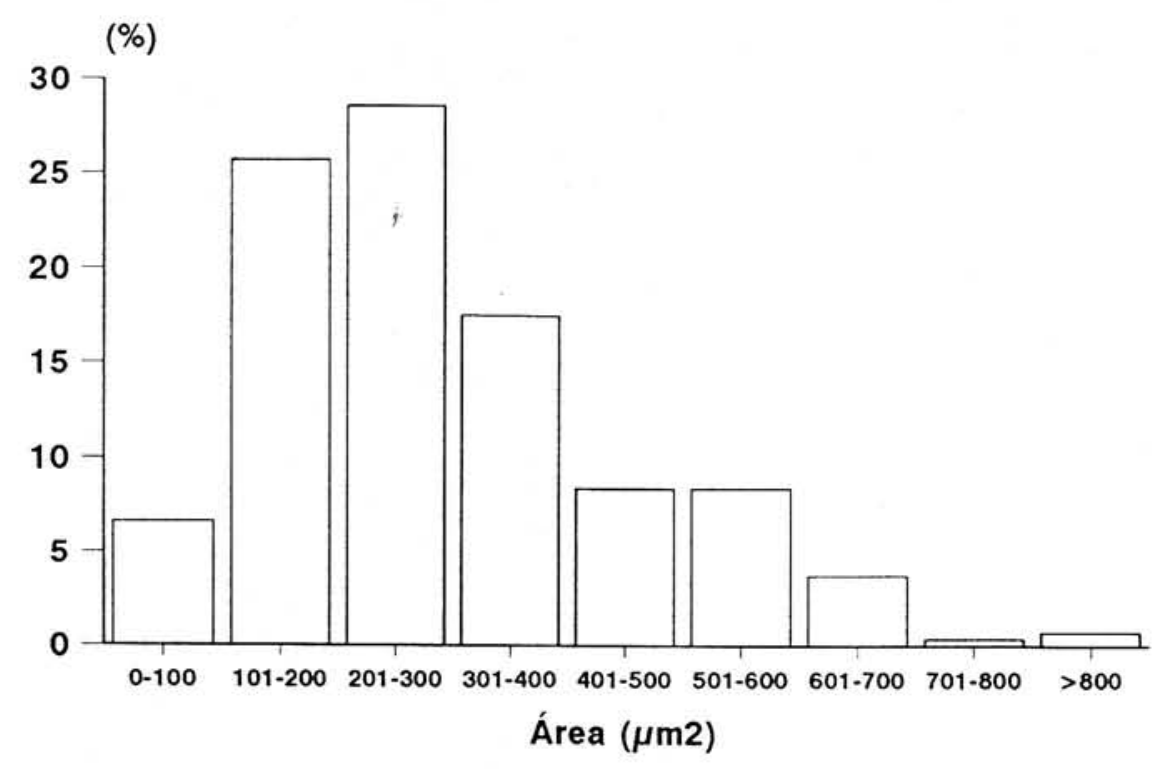

Distribuição dos neurônios do plexo mientérico do colo sigmóide de acordo com a área da imagem do corpo celular

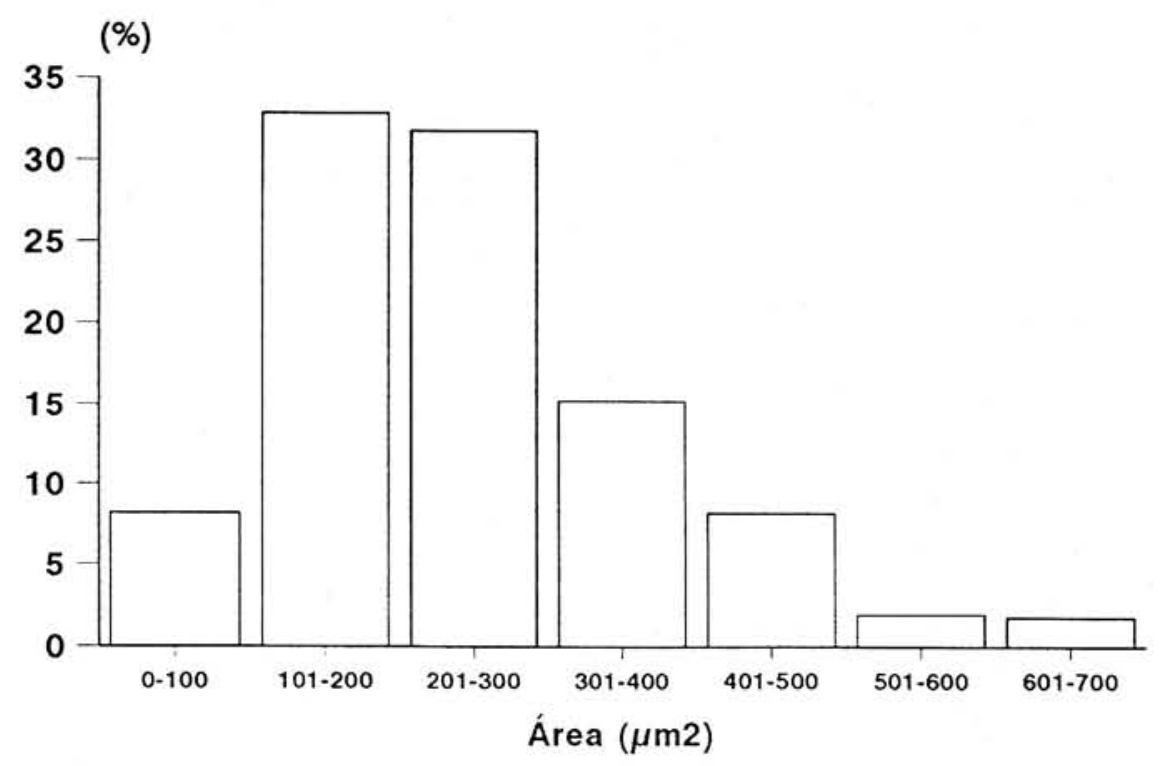



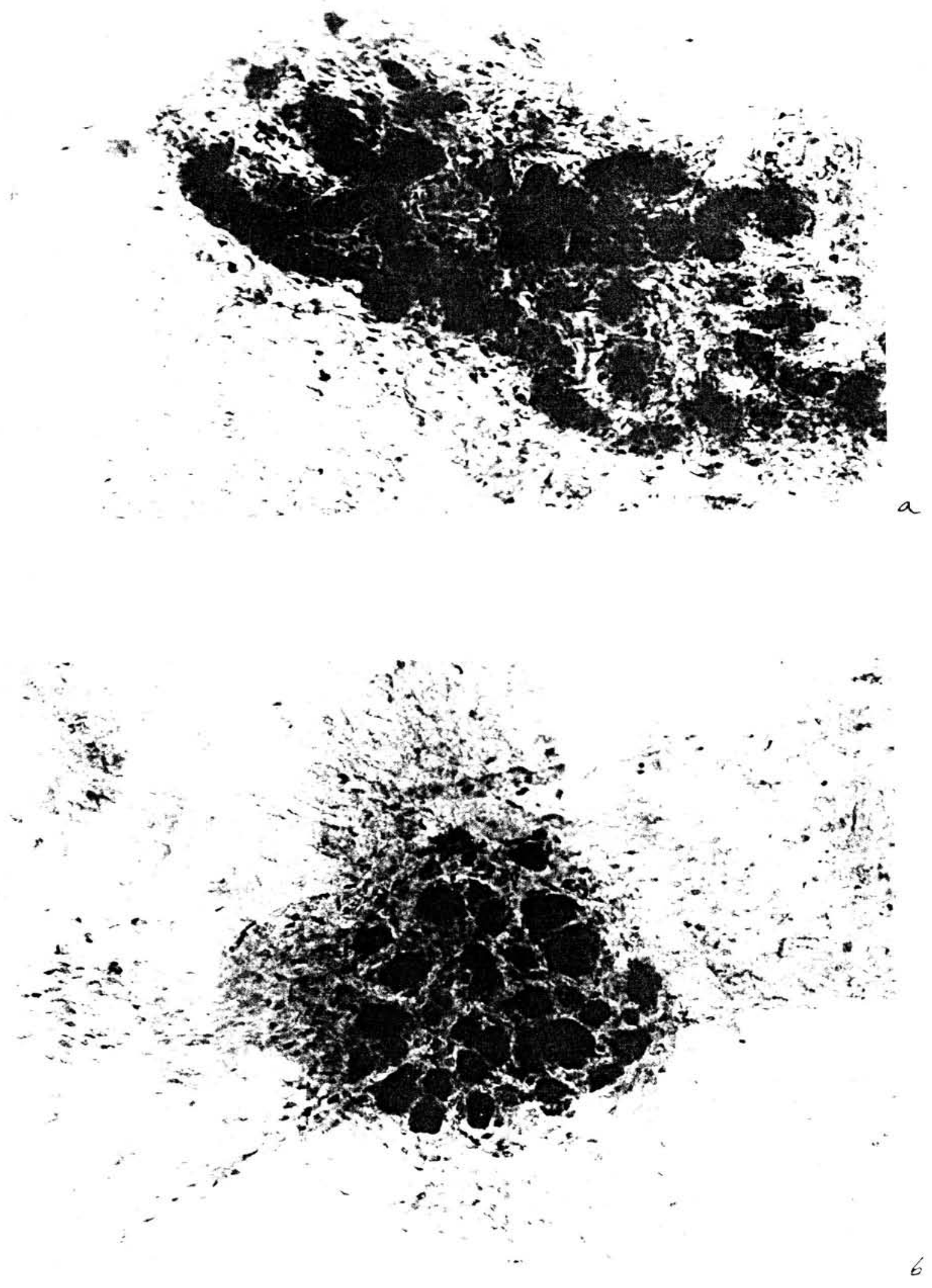


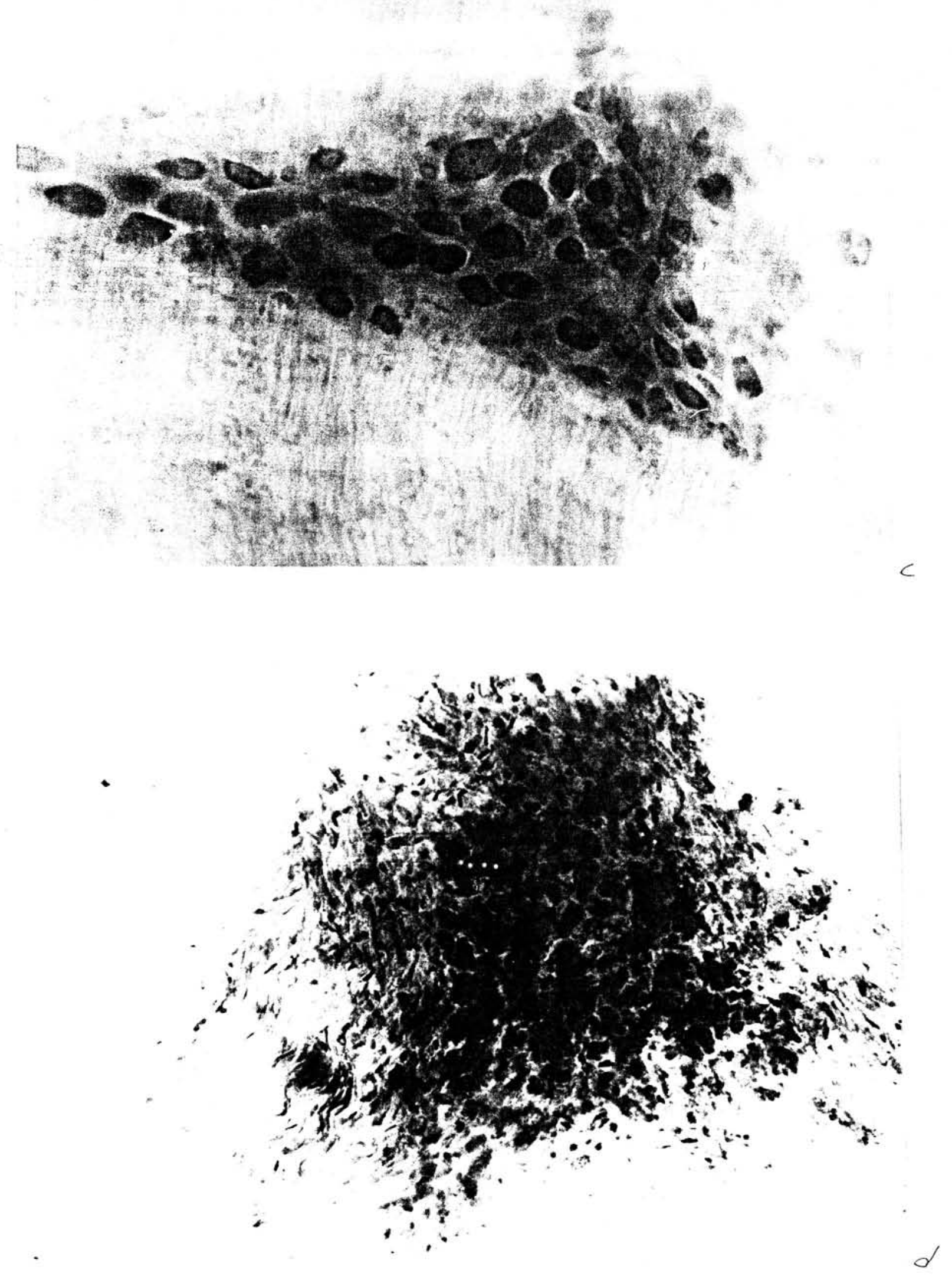


TRABALHO IX 
Número de neurônios do plexo cardiaco dos átrios e do plexo mientérico do colo sigmóide do Calomys callosus na fase crônica da infecção experimental pelo $T$. cruzi

\author{
(De-Souza, R.R.; Vasconcelos, D.C.; Maifrino, L.B.M.; Liberti, E.A.)
}

\title{
INTRODUÇÃO
}

Estudos sobre os efeitos da infecção chagásica experimental sobre neurônios do sistema nervoso autônomo tem sido realizados em várias espécies. Dentre estes efeitos destaca-se a destruição neuronal. A doença de Chagas reduz particularmente o número de neurônios do plexo mientérico do colo, bem como dos gânglios cardiacos, provocando importantes alterações na motilidade e condução nervosa nestes órgãos (ZANOTTO \& OKUMURA, 1967).

Entre os animais de laboratório mais utilizados para estes estudos estão a cobaia (FALANGOLA et al., 1990), o rato (ALCÂNTARA \& OLIVEIRA, 1964) e o camundongo (ANDRADE \& ANDRADE, 1966). Em todas estas espécies verificase perda de neurônios com a infecção chagásica.

O Calomys callosus é um roedor silvestre que foi encontrado naturalmente infectado pelo $T$. cruzi (RIBEIRO, 1973). Esta espécie é facilmente adaptável para viver e reproduzir-se sobre condições de laboratório (MELLO, 1981), apresentando baixa mortalidade quando infectado pelo $T$. cruzi. Por apresentar alta resitência à infecção por $T$. cruzi, o Calomys callosus vem sendo muito utilizado para estudos fisiológicos e imunológicos (VAZ LIMA \& DIAS DA SILVA, 1986; bOIM \& SCHOR, 1989), bem como relacionados à molestia de Chagas (BORGES et al., 1992).

Não são registrados na literatura trabalhos sobre os efeitos da infecção chagásica sobre os neurônios do colo e do coração de $C$. callosus.

No presente trabalho, pretende-se determinar se ocorre uma diminuição do número de neurônios por área (densidade neuronal) do plexo mientérico do colo e do número de neurônios do plexo cardiaco do $C$. callosus infectado por $T$. cruzi a 
fim de verificar se estes neurônios são ou não resitentes à infecção por este tripanosomídeo.

\section{MATERIAIS E MÉTODOS}

Foram utilizados quatorze C. callosus machos, adultos, com peso entre 30$40 \mathrm{~g}$, sendo seie animais inoculados, por via intraperitoneal, com $1 \times 10^{5}$ formas da cepa $Y$ do $T$. cruzi logo após o desmame, e sete animais não infectados, utilizados como controle.

Quarenta dias após a inoculação, os animais foram sacrificados com overdose de éter, e em seguida, para estudo dos neurônios do plexo mientérico, tiveram a cavidade abdominal aberta, sendo removido um segmento de $4 \mathrm{~cm}$ de comprimento do colo sigmóide, que foi lavado com solução de Krebs. Cada segmento foi então ligado com fio de algodão em ambas as extremidades e ligeiramente distendidos com solução de Krebs através de uma seringa introduzida em uma das extremidades. A seguir, os segmentos foram abertos pela borda mesenterial, tendo sido removidas a mucosa e a submucosa, mantendo-se a túnica muscular contendo em seu interior, o plexo mientérico.

Para o estudo dos neurônios cardíacos, após a abertura do tórax e do pericárdio, o coração foi retirado seccionando-se os vasos da base. A seguir, através de uma incisão no sulco coronário, os átrios foram separados dos ventrículos, e, após a retirada da aorta e do tronco pulmonar e a redução do septo interatrial, os átrios foram abertos.

A evidenciação dos neurônios cardiacos e do plexo mientérico do colo foi realizada através do método de demonstração da enzima NADH-tetrazolium reductase (GABELLA, 1969).

Os segmentos do colo e os átrios foram então montados como preparados totais de membrana, entre lâmina e lamínula em solução de glicerol a $70 \%$.

Todos os neurônios presentes na parede atrial foram contados sob microscópio de luz com aumento de 125X; para o colo, foram contados os neurônios de 50 campos de $0,14 \mathrm{~mm}^{2}$ cada, escolhidos aleatoriamente, com 
aumento de 400X. Em seguida, determinou-se a média e desvio-padrão das densidades dos neurônios do colo e dos átrios.

$O$ perfil de 100 neurônios do plexo mientérico e 50 neurônios dos átrios selecionados ao acaso em cada preparado total foi determinado através de um analisador de imagem semi-automático (MINI-MOP KONTRON BILDANALYSE), com uma câmara clara adaptada a um microscópio.

As comparações estatísticas foram feitas utilizando-se o teste " $\mathrm{t}$ " de Student.

\section{RESULTADOS}

Os gânglios do plexo mientérico do colo sigmóide dispõem-se em colunas alongadas, com direção paralela à camada muscular circular do colo (Fig. 1a). No interior dos gânglios, os neurônios apresentam tamanhos e formas variadas, com citoplasma bem corado e núcleos claros arredondados ou ovalados.

Neurônios degenerados ou ern degeneração, com contorno citoplasmático bastante alterado, entremeados a neurônios de aspecto normal, foram verificados nos gânglios dos animais infectados (Figs. 1b, c).

Os gânglios cardíacos foram encontrados exclusivamente na face externa da parede atrial. Não foi observado um padrão de distribuição dos gânglios, ocorrendo uma nítida variação, neste aspecto, de um animal para outor nos grupos infectado e controle. Gânglios alterados com neurônios destruídos foram também observados (Figs. 1d, e, f)

O número total de neurônios do colo sigmóide bem como dos átrios estimado para cada animal de cada grupo, bem como as respectivas médias e desvios padrões, estão representados nas tabelas 1 e 2 .

A densidade média de neurônios no colo sigmóide, foi de $44928 \pm 6145$ nos animais infectados por $T$. cruzi, enquanto que nos animais do grupo controle a densidade média foi de $59200 \pm 4800$. A diferença entre os grupos mostrou-se estatisticamente significante (p. 0,05). 
O número médio de neurônios e desvios-padröes observados nos átrios foram de $446 \pm 151$ para o grupo chagásico e $659 \pm 120$ para o grupo controle, sendo a diferença entre ambos, estatisticamenie significante $(p<0,05)$.

Os histogramas de distribuição da frequência das áreas dos corpos celulares para o colo e para os átrios estão expressos na figura 2, onde verificouse que, para o colo, destaca-se a maior concentração dos corpos neuronais entre $0-100 \mu \mathrm{m}^{2}$ nos animais infectados. Nos átrios, a maior concentração foi verificada no intervalo de $200-300 \mu \mathrm{m}^{2}$ para os animais do grupo controle.

\section{DISCUSSÃO}

Um importante aspecto na infecção por $T$. cruzi é a alteração no número de células neuronais. No plexo mientérico, a redução no número de neurônios com a infecção, foi observada no intestino do rato (ANDRADE \& ANDRADE, 1966), do camundongo (OKUMURA, 1966) e do homem (COSTA \& LIMA, 1964), sendo esses resultados baseados na análise de cortes histológicos. Entretanto, as contagens realizadas em preparados totais de membrana d se diversas vísceras, fornecem resultados mais precisos (IRWIN, 1931; CHRISTENSEN \& ROBINSON, 1982).

Dentre as técnicas utilizadas para evidenciação de neurônios em preparados de membrana é o método histoquímico desenvolvido por GABELLA (1969), que tem sido amplamente empregada para estudos quantitativos dos plexos entéricos em diversas espécies animais (GABELLA, 1969, 1979, 1987, 1989; ALI \& MCLELLAND, 1979; SCHEWERMANN \& STACH, 1983). No presente trabalho, este método mostrou-se adequado não somente para contagens de neurônios do plexo mientérico do colo sigmóide, mas também para os neurônios do plexo atrial, tanto nos animais normais como nos animais infectados, conferindo às membranas especificidade e uniformidade na coloração, possibilitando contagens mais fidedignas do que as realizadas em cortes histológicos.

A constatação de que a densidade neuronal média do colo sigmóide do C.callosus infectado foi significativamente menor que a verificada para o grupo 
controle, indica que cerca de $25 \%$ da população de neurônios do plexo mientérico do colo foram destruídas.

Da mesma forma, o número total de neurônios dos átrios dos animais infectados demonstrou ser significativamente menor quando comparado com os valores obtidos para os animais do grupo controle, representando uma destruição de cerca de $\lrcorner 2 \%$ das células nervosas do plexo cardíaco.

A análise dos histogramas permite inferir que, no colo, a destruição neuronal ocorre nas células com pericários acima de $100 \mu \mathrm{m}^{2}$, observando-se uma preservação dos neurônios de área menor. No plexo cardiaco dos átrios, pode-se admitir que a destruição é mais uniforme, ou seja, neurônios de diversos tamanhos são afetados pela infecção.

As lesões neuronais observadas nos plexos do colo e coração tiveram uma distribuição irregular e imprevisível; em um mesmo gânglio podiam ser encontrados diversos alterados ou mesmo bastante degenerados, ao lado de outros poucos alterados ou mesmo de aspecto normal. Isto de certa forma é compreensível, uma vez que o $T$. cruzi pode parasitar um determinado órgão de várias formas, sendo sua distribuição aleatória (TAFURI, 1971).

A destruição de neurônios relacionada com a infeç̧ão pelo $T$. cruzi tem sido justificada de várias maneiras. Os neurônios são raramente parasitados nas infecções de T. cruzi (KÖBERLE \& ALCÂNTARA, 1960), o que torna improvável que sua destruição seja um efeito direto da invasão do parasita. Segundo TAFURI (1968), as lesões neuronais mostram relação direta com a inflamação provocada pelos parasitas localizados nas vizinhanças dos gânglios.

Pode existir também uma relação indireta com a infecção, provocada por liberação ou ativação de substâncias tissulares, semelhantes a neurotoxinas, que poderiam provocar distúrbios nas células nervosas (ANDRADE \& ANDRADE, 1966).

Outros autores sugerem que a destruição neuronal poderia ser produzida por uma resposta auto-imune elictada por antígenos dos parasitas que reagem diretamente com os componentes do tecido hospedeiro (TEIXEIRA et al., 1975). 
Os resultados obtidos no presente trabalho permitem concluir que embora - C. callosus seja resitente à infecção pelo $T$. cruzi, alguns de seus tecidos específicos parecem não ser. É o caso dos neurônios do plexo cardíaco dos átrios e do plexo mientérico do colo sigmóde, os quais sofrem destruição quando o animal é infectado. Neste aspecto, embora admita-se que o Calomys callosus seja um animal com alta resistência à infecção pelo $T$. cruzi, as alterações dos plexos são semelhantes às verificadas em outros roedores frente à infecção (ALCÂNTARA et al., 1964; HAASE, 1964), se bem que com um grau de destruição neuronal bem menor do que observado nestes animais. 


\section{Referências Bibliográficas}

ALCÂNTARA, F.G. \& OLIVEIRA, J. A. M. - Avaliação quantitativa dos neurônios dos plexos mientéricos e submucoso no rato Wistar. Hospital (Rio) 66: 119-124, 1964.

ALI H.A. AND MCLELLAND F. - Neuron number in the intestinal myenteric plexus of the domestic fowl (Gallus gallus). Zenbl. Vet. Med. C. Anat. Histol. Embryol. 8: 277-283, 1979

ANDRADE, S.G. \& ANDRADE, Z.A. - Doença de Chagas e alterações neuronais no plexo de Auerbach (Estudo experimental em camundongos). Rev. Inst. Med. trop. São Paulo 8: 219 - 224, 1966.

BOIM, M.A. E SCHOR, N. - Hemodinâmica glomerular renal no roedor Calomys callosus. Rev. Soc. Bras. Med. tropical, 22: 31-37,1989.

BORGES, M.M.; MELLO, D.A. E TEIXEIRA, M.L. - Infecção experimental de Calomys callosus (Rodentia, Cricetidae) com Trypanosoma cruzi. Rev. Saúde Pública (S. Paulo), 16: 223-242, 1982.

CHRISTENSEN, J. E ROBINSON, B.A. - Anatomy of the myenteric plexus of the opossum esophagus. Gastroenterology 83: 1033-1042, 1982.

COSTA, R.B. \& LIMA FILHO, E.C. - Plexos submucoso e mientérico no cólon humano na moléstia de Chagas. Rev. Inst. Med. trop. São Paulo 6: 211218, 1964.

FALANGOLA, M.F.; QUEIROZ, A.C.; ANDRADE, S.G. \& SADIGURSKY, M.

- The involvement of the central nervous system in acute chagasic infection Comparative histopathologic and immunologic study in three species of animals infected with three strains of T. cruzi.. Mem. Inst.Oswaldo Cruz 85, pág. 14, 1990.

GABELLA, G. - Detection of nerve cells by a histochemical techinique. Experientia, 25: 218 -219, 1969

GABELLA, G. - Innervation of the gastrointestinal tract. Int. Rev. Cytol. 59 : 129 193, 1979. 
GABELLA, G. - Structure of muscles and nerves in the gastrointestinal tract. In: Physiology of the Gastrointestinal Tract.(edited by Johnson, L.L.).pp. 194-241. New York, Raven Press, 1987.

GABELLA, G. - Fall in the number of myenteric neurons in aging guinea - pigs. Gastroenterology; 96: 1487 - 1493, 1989.

GAMA. E.F., FERRAZ DE CARVALHO, C.A., VASCONCELOS, D.C., LIMA, N.K.C., HEIMANN, J.C. E DE SOUZA, R.R. - Dietary sodium intake and cardiac nerve cell hypertrophy in Wistar rats, 1996.

HAASE, H. B. - Moléstia de Chagas experimental. Tempo de trânsito gastrointestinal. Hospital (Rio) 65: 599-616, 1964.

IRWIN, D.A. - The anatomy of Auerbach's plexus. Am. J. Anat., 49: 141-66, 1931.

KÖBERLE F. \& ALCÂNTARA, F.G. - Mecanismo da destruição neuronal do sistema nervoso periférico na Moléstia de Chagas. Hospital (Rio de J.), 57, 1057., 1960.

OKUMURA, M. - Contribuição das lesões dos neurônios do plexo mientérico do colo na moléstia de Chagas experimental no camundongo branco (Mus musculus, L) São Paulo, 1966 (Tese - Faculdade de Medicina da Universidade de São Paulo).

RIBEIRO, R.D. - Novos reservatórios do Tripanosoma cruzi. Rev. Bras. Biol., 3; 429 - 537, 1973.

SCHEWERMANN D.W. AND STACH W. - A simultaneous demonstration of particular enteric neuronal cell types with the NADH : Nitro BT - dehydrogenase reaction and of nerve fibres containing enkephalin - like immunoreactivity in the myenteric plexus of the porcine small intestine. Histochemistry 82: 269-273, 1985.

SONIA G. ANDRADE E ZILTON A. ANDRADE - Doença de Chagas e Alterações neuronais no plexo de Auerbach. Rev. Inst. Med. Trop. São Paulo; 8: $219-224,1966$.

TAFURI, W.L. - Patogênese das lesões do sistema nervoso autônomo do intestino na doença de Chagas experimental. Rev. Goiana Med. 14: 11-19, 1968. 
TAFURI, W.L.; MARIA, T.A \& LOPES, E.R. - Lesões do plexo mientérico do esôfago, do jejuno e do colo de chagásicos crônicos. Estudo ao microscópio eletrônico. Rev. Inst. Med. trop. São Paulo 13:76-91, 1971.

TEIXERA, A.R.L.; TEIXEIRA M.L. \& SANTOS - BUSH, C.A. - The immunology of experimental Chagas' disease. IV Production of lesions in rabbits similar to those of chronic Chagas' disease in man. Am. J. Pathol. 80. 163, 1975 .

VAZ LIMA, L.R.A. E DIAS DA SILVA, W. - The complement System in the wild rodent Calomys sp (Rodentia - Cricetidae). Laboratory Animal Science Regional ( International Scientific Meeting). Águas de Lindóia, SP, pg 150, 1986.

ZANOTTO, A. \& OKUMURA MASAYUKI - Alterações da motricidade do íleo isolado do camundongo chagásico. Rev. Inst. Med. trop. São Paulo 9: 98-106, 1967. 
Figura 1- a- Aspecto geral do plexo mientérico do colo sigmóide de Calomys callosus; b, c- Neurônios com citoplasma alterado observados no plexo de animais infectados (setas) entremeados a neurônios de aspecto normal (cabeça de seta); d- Gânglios do plexo cardíaco dos átrios de animais normais, com neurônios apresentando contornos regulares; e, f- Gânglio do plexo cardíaco dos átrios de animais infectados, onde śe observam, além da distribuição mais esparsa, neurônios com citoplasma de contorno alterado ou pouco corado (setas). (NADH. a- 100X; b, f- 720X; c- 1100X; d, e- 400X).

Figura 2- Distribuição das áreas dos neurônios do plexo mientérico do colo e dos átrios do Calomys callosus, em animais normais e infectados.

Tabela 1- Densidade neuronal do plexo mientérico do colo de Calomys callosus, nos grupos controle e infectado.

Tabela 2- Densidade neuronal do plexo cardíaco dos átrios de Calomys callosus, nos grupos controle e infectado. 

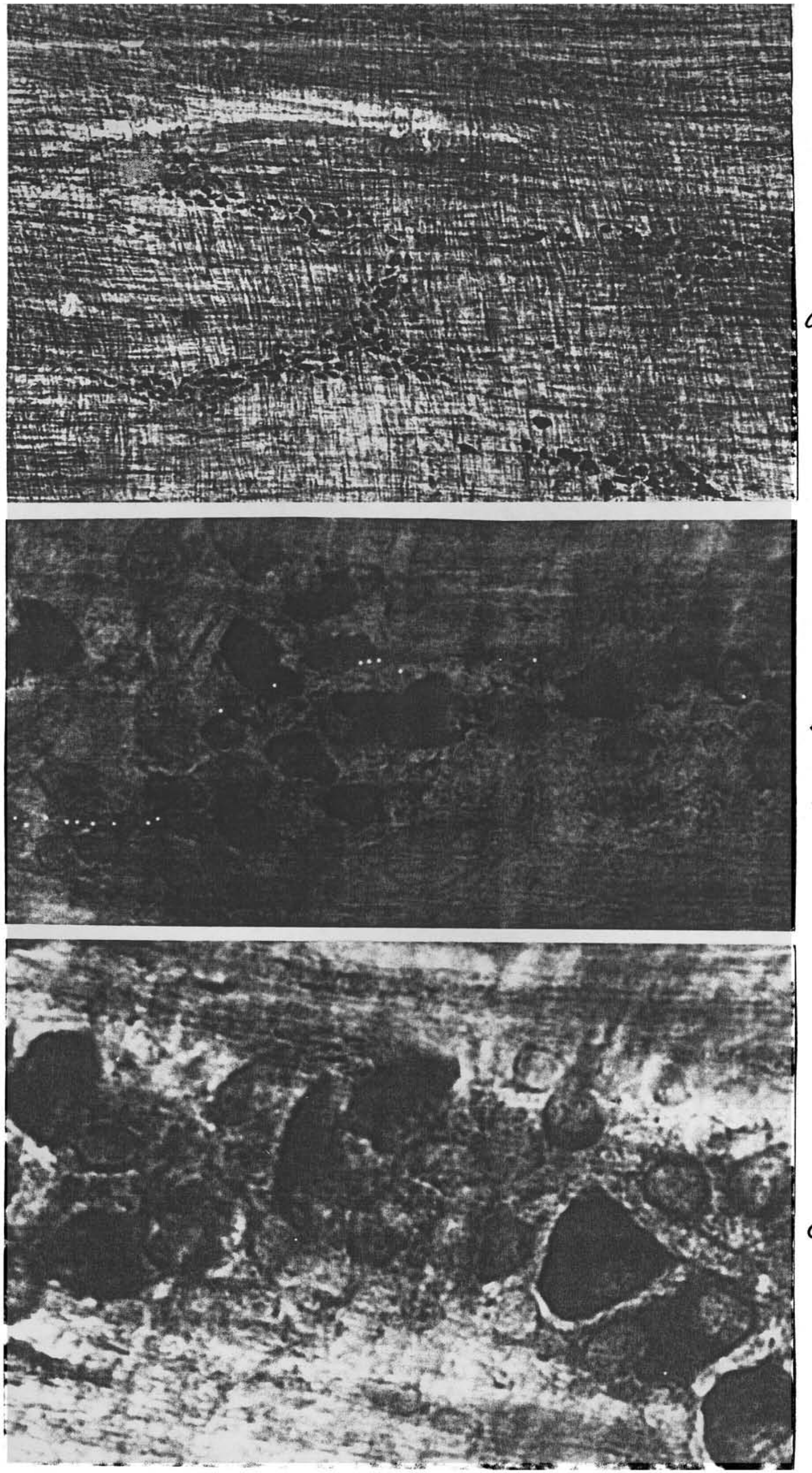

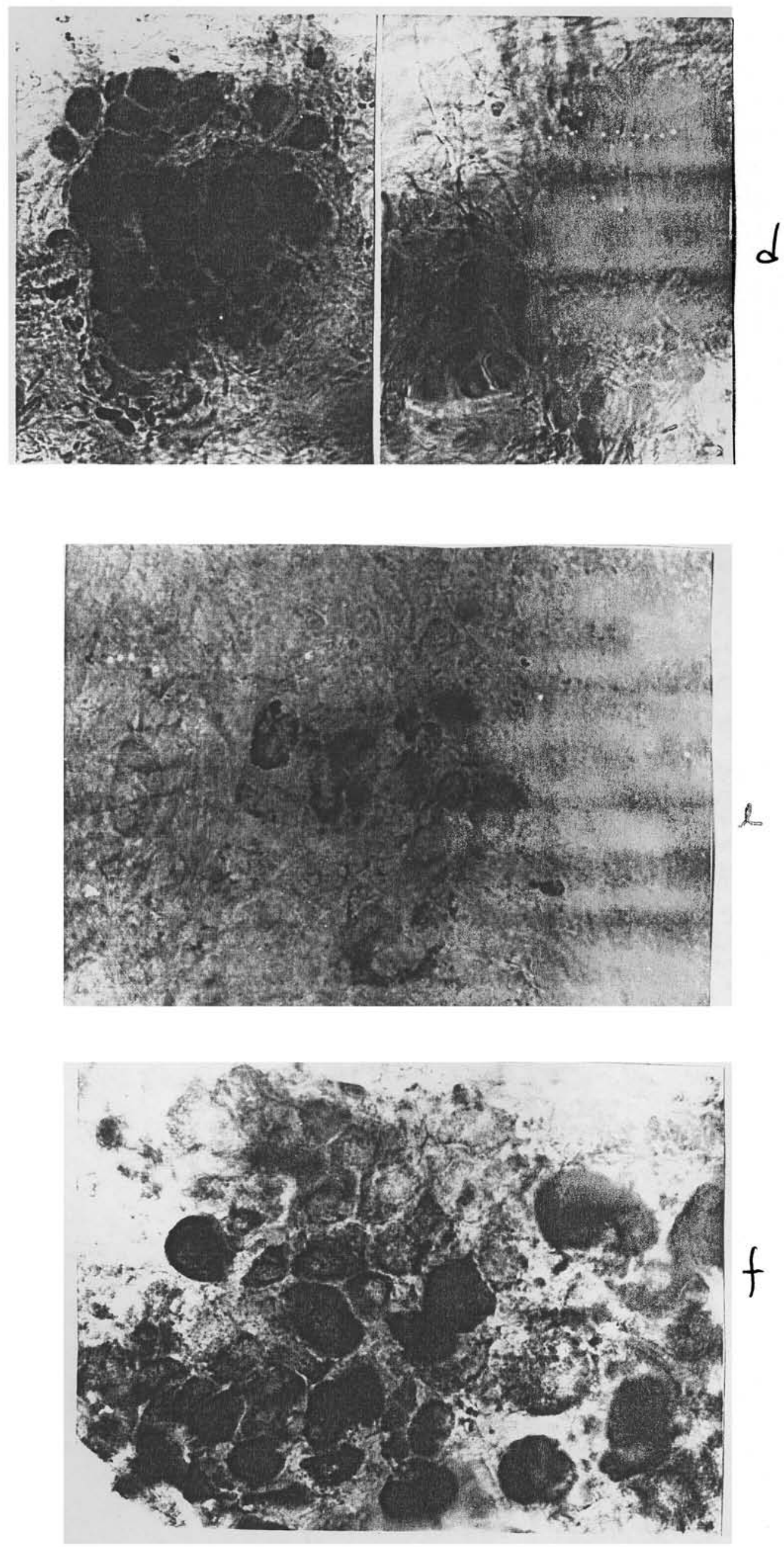
Colo

(\%)

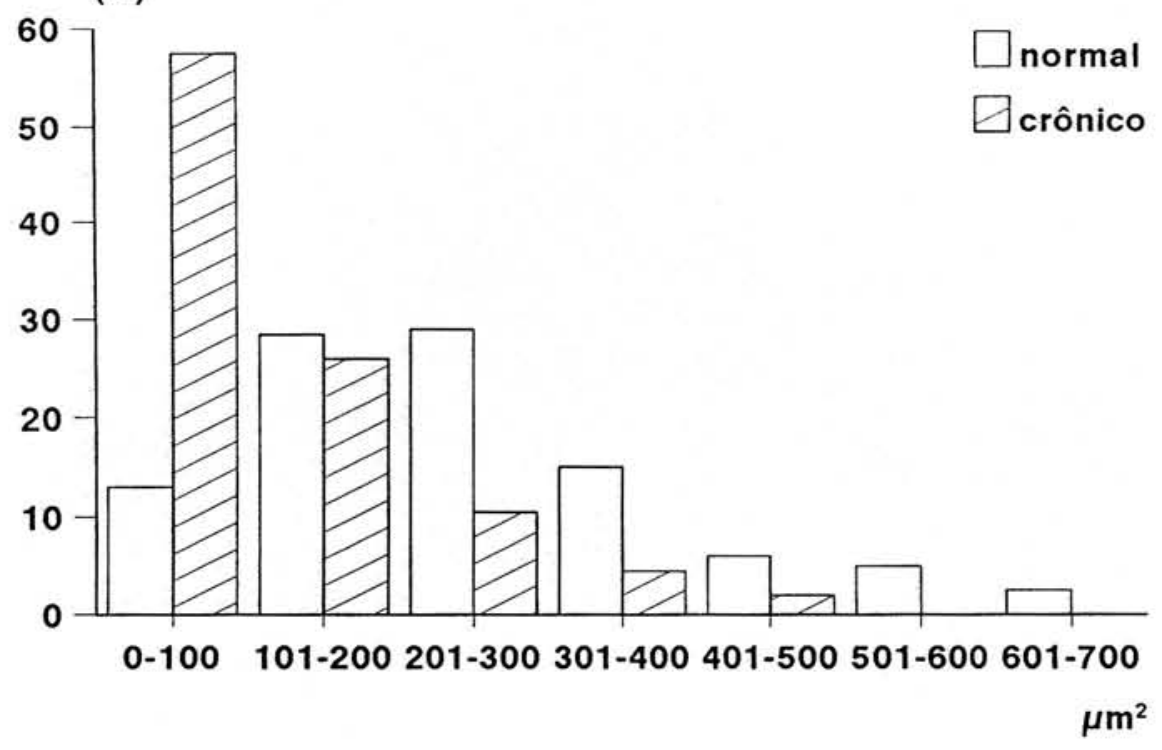

Coração

(\%)

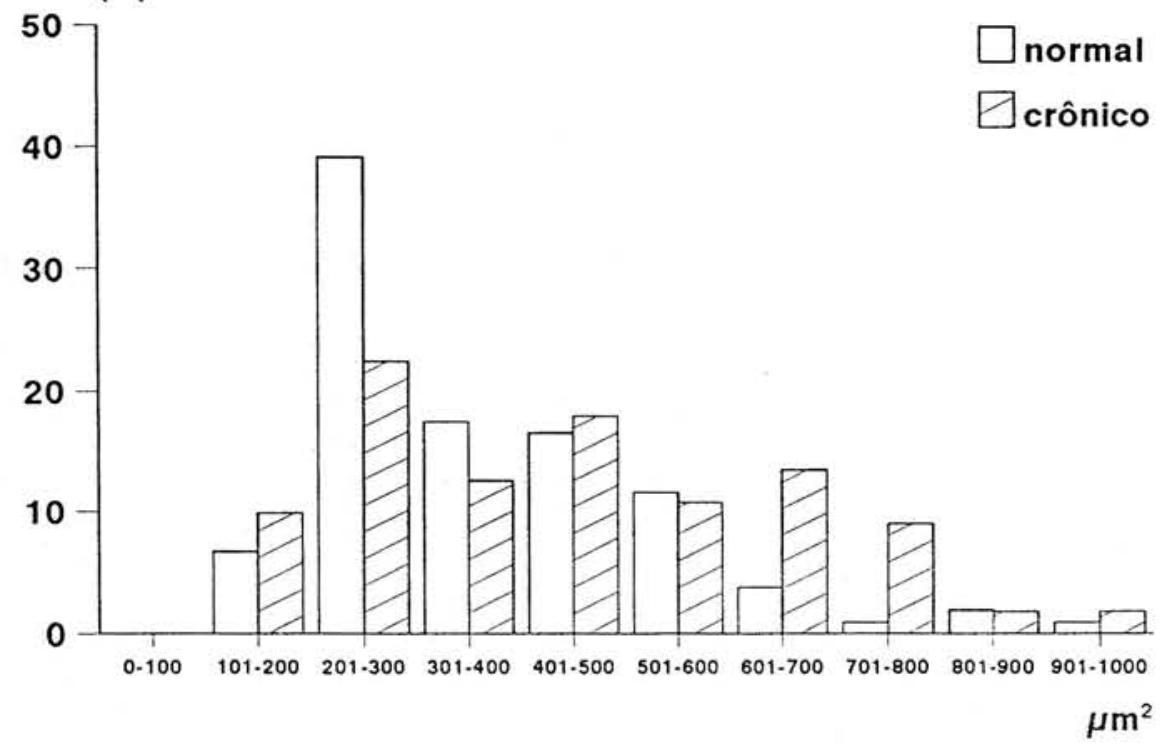




\begin{tabular}{|c|c|c|}
\hline \multirow[t]{2}{*}{ Animal } & \multicolumn{2}{|c|}{ Número de neurôni'ss $/ \mathrm{cm}^{2}$} \\
\hline & controle & chagásico \\
\hline 1 & 55700 & 41100 \\
\hline 2 & 63900 & 59000 \\
\hline 3 & 62100 & 40800 \\
\hline 4 & 57900 & 47700 \\
\hline 5 & 65300 & 42300 \\
\hline 6 & 58500 & 41300 \\
\hline 7 & 51500 & 42300 \\
\hline média & 59200 & 44928 \\
\hline desvio - padrão & 4800 & 6145 \\
\hline
\end{tabular}

\begin{tabular}{|c|c|c|}
\hline \multirow[t]{2}{*}{ Animal } & \multicolumn{2}{|c|}{ Número de neurônios } \\
\hline & controle & chagásico \\
\hline 1 & 593 & 516 \\
\hline 2 & 838 & 588 \\
\hline 3 & 804 & 212 \\
\hline 4 & 514 & 208 \\
\hline 5 & 580 & 539 \\
\hline 6 & 607 & 547 \\
\hline 7 & 677 & 514 \\
\hline média & 659 & 446 \\
\hline desvio - padrão & 120 & 151 \\
\hline
\end{tabular}




\section{TRABALHO $\mathrm{X}$}




\title{
MORPHOLOGICAL AND QUANTITATIVE STUDY OF \\ GANGLIONATED PLEXUS OF Calomys Callosus TRACHEA
}

\author{
(Furlani, V.C.G.; Liberti, E.A.; Maifrino, L.M.B.; Borges, N.; Moraes, S.R.; \\ De-Souza, R.R.)
}

\section{Introduction}

The trachea of mammals is innervated by nerve fibers from the vagus nerve, from the sympathetic chain and by a group of ganglia situated at its dorsal surface. The ganglia are small and anatomically and physiologically they are much less well understood than the sympathetic ganglia or the ganglia of the intestine and urinary tract (CHIANG \& GABELLA, 1986). According to BAKER et al. (1986), although a great deal has been learned about the part of the parasympathetic motor pathway that controls airway smooth muscle and submucosal glands, little has been learned about transmission in airway parasympathetic ganglia.

HONJIN (1954), described in mice, many small tracheal ganglia as a long chain. CHIANG \& GABELLA (1986) related that the plexus lies exclusively over the muscular part of the mice trachea, dorsal to the muscle itself, and it varies considerably in pattern and extent between individual animals. In young and in adult mice the plexus contain on average 235 neurons that are relatively small, measuring an average of $251 \mu \mathrm{m}^{2}$ in young and 341 $\mu \mathrm{m}^{2}$ in ageing animals. In the ferret trachea the architecture of the nerves and ganglia consisted of one or two longitudinal nerve trunks overlying the posterior surface of the trachealis muscle (BAKER et al., 1986). Ganglion cell bodies were present along the longitudinal nerve trunks with an mean diameter of $34.3 \pm 0.3 \mu \mathrm{m}$ usually attached to the nerve trunk by a stalk and loosely clustered in groups of as many 38 cell bodies. They observed yet two superficial nerve plexus containing ganglia of one to four small neurons (mean diameter $24.2 \pm 0.3$ ) so-called superficial muscle and gland plexuses overlying the smooth muscle and submucosal glands and two deep nerve plexuses providing the terminal innervation to the muscle and glands.

The objectives of the present investigation are to describe the ganglionated plexus of the Calomys callosus trachea, and to determine the presence of acetylcholinesterase $(\mathrm{AChE})$, the number of neurons and the neuronal cell profile areas of the plexus. 
The objectives of the present investigation are to describe the ganglionated plexus of the Calomys callosus trachea, and to determine the presence of acetylcholinesterase (AChE), the number of neurons and the neuronal cell profile areas of the plexus.

Our interest in this animal specie is due to the fact that it was described as harbouring of the Chagas'disease and has low susceptibility to infection by the Trypanosoma cruzi (RIBEIRO, 1973).

\section{Materials and Methods}

Seventeen male adult Calomys callosus weighing 30 to $35 \mathrm{~g}$. were used. Thirteen animals were sacrificed with an overdose of ether and the chest was opened. The trachea and main bronchi were dissected away and prepared according to CHIANG \& GABELLA (1986) description, i.e., cotton thread ligatures were placed on the bronchi at the level of the hilum of the lung and around the larynx, where a bulbed needle connected to a syringe had been inserted.

\section{Number of ganglia and neurons}

A fixative solution (BARBOSA, 1978) was injected into the trachea and main bronchi of six animals. The pieces were then immersed in the same fixative solution, opened along the ventral midline and flattened on wax plate pinning the borders. The mucous membrane was dissected away and the pieces were maintened in the fixative for 18 hours. The specimens were immersed during $10 \mathrm{~min}$. in Sörensen buffer solution $(\mathrm{pH}$ 6.9) and were stained using a modified Giemsa technique (BARBOSA, 1978). They were dehydrated in an alcohol series, diaphanized with xylene and had the connective tissue covering the muscle layer with part of the muscle fibers and the remaining of the mucous membrane removed under dissecting microscope $(40 \mathrm{X})$. They were mounted in resin as whole-mount preparations. The number of garglia as well as the number of neurons/ganglion and isolated or paired neurons were counted in all specimens. 


\section{Morphometry}

In three specimens a Krebs solution (GABELLA, 1969) was injected and the trachea was then immersed in the same solution After being left for 15-30 min. in Krebs solution at room temperature, the specimens were transferred to a permeabilizing agent ( $0,3 \%$ solution of Triton- $X$ in Krebs solution during $15-90 \mathrm{sec}$.) and were submitted to 3 changes of Krebs solution for about $10 \mathrm{~min}$. and then incubated for $30-90 \mathrm{~min}$. at $20^{\circ} \mathrm{C}$ in $20 \mathrm{ml}$ of incubation medium containing: Nitro blue tetrazolium (Sigma), $0.5 \mathrm{mg} / \mathrm{ml}$ in distilled water ( 25 parts), $0.1 \mathrm{M}$ sodium phosphate buffer ( $\mathrm{pH}$ 7.3) (25 parts), distilled water ( 50 parts) and B-nicotinamide adenine dinucleotide (reduced form) $0.5 \mathrm{mg} / \mathrm{ml}$ (GABELLA, 1969). The development of the reaction was monitored under a dissecting microscope and it was stopped by immersion of the pieces in buffered $10 \%$ formalin, in which they were fixed for a minimum of $24 \mathrm{~h}$. Laminar preparations of the pieces were then made and mounted in glycerol as whole-mount preparations. The profiles of 50 nerve cell perikarya from each trachea were outlined and analyzed using a semi-automatic image analyzer (MINI-MOP KONTRON BILDANALYSE) with a camera lucida attached to the microscope.

\section{Histology}

A $10 \%$ formalin solution was injected in three specimens that were immersed in the fixative for for 48 to $72 \mathrm{~h}$ and were placed in $0.1 \mathrm{M}$ phosphate buffer ( $\mathrm{pH} 7.4$ ) for $24 \mathrm{~h}$. Rings about $1 \mathrm{~cm}$ from the superior, middle and inferior regions of the trachea were dehydrated in an increasing alcohol series, immersed in benzol for $20 \mathrm{~min}$ and embedded in parafiin. Transverse sections of $10 \mu \mathrm{m}$ thick were stained to visualize the elastic fibers (WEIGERT, 1898; VERHÖFF, 1908; COTTA-PEREIRA et al., 1976), and the collagen fibers (ROMEIS, 1968; JUNQUEIRA et al., 1978; JUNQUEIRA et al., 1979).

\section{AChE activity}

For the histochemical demonstration of acetylcholinesterase the "direct colouring" copper ferrocyanide method (KARNOWSKY \& ROOTS, 1964) was used in fresh tissues of the four remaining animals and prepared as whole-mount preparations. 


\section{Results}

The ganglia were found exclusively over the membranous part of the trachea encapsulated by a thin membrane of collagen fibers. Few elastic fibers were observed around or inside the ganglion (Figs. 1a, b).

All the Calomys callosus trachea examined were densely innervated by neurons with AChE activity. Two longitudinal nervous trunks lying posteriorly to the tracheal membrane near the borders of the cartilaginous rings were present. In some cases, the trunks were separated only or in the inferior or in the superior region of the organ fusing (joining) in the complementary portion. A diverse number of ganglia was observed along the intrincate network of nerves inteconnecting the trunks (Figs. 1c, d, e). Thin nerve fibers arising from this network form a small plexus between the cartilaginous ring and other delicate fibers involve the tracheal vessels (Figs. 1f, g).

In the specimens stained with Giemsa's method the ganglia were observed over the dorsal surface of the tracheal muscle and were rare between the cartilaginous tracheal rings. There were no pattern of distribution of the ganglia along the organ, i.e., they varied between individual animals (Fig. 2a). The ganglia were round or elongated or irregular in shape. Most of then were small being the largest ganglion found with 45 neurons (2b-d). In the same ganglia, densely packed elongated, oval or round neurons were recognized with small, medium and large perikarya, intermingled with satellite cells (2e). Isolated or paired neurons agregated to an nervous fiber bundle were sometimes present (Figs. 2f).

The total numbers of neurons/ganglion, neurons and ganglia in 6 whole-mount preparations are shown in Table 1 . The average numbers ( \pm Standard deviation) were respectivelly $15.08 \pm 1.31,279 \pm 51.8$ and $18.17 \pm 2.6$. The most frequent ganglia had up to 20 neurons $(77.7 \%)$.

The ranges of perikaryon area and the mean perikaryal area are shown in Fig. 3. The perikaryal areas ranged from $33.37 \mu \mathrm{m}^{2}$ to $805.89 \mu \mathrm{m}^{2}$, and most of the neurons had a perikaryal area in the interval from $300 \mu \mathrm{m}^{2}$ to $400 \mu \mathrm{m}^{2}$. The mean was $352.72 \mu \mathrm{m}^{2}$. 


\section{Discussion}

As related by GABELLA (1986), two essential conditions required for the quantitative work are specificity of staining and uniformity of staining. Both the histochemical (KARNOWSKY \& ROOTS, 1964; GABELLA, 1969) and nonhistochemical (BARBOSA, 1978) methods we have used to identify nerves and ganglion neurons of the trachea has been used before in diverse viscera including the trachea (GABELLA, 1971; SMITH \& TAYLOR, 1971; SANTER \& BAKER, 1988; CHIANG \& GABELLA, 1986; DE-SOUZA et al., 1993; LIBERTI et al., 1994a).

CHIANG \& GABELLA (1986) described that the possibility that other ganglia are located deeper inside the trachea and are not stained with their method is unlikely, because they did not see any deeply-seated ganglia in thin sections of trachea, and because the membranous wall of the mouse trachea is sufficiently thin $(22-28 \mu \mathrm{m})$ for the incubation medium to reach all parts of the wall. Our results corroborate these assertives once that nor with the histochemical and non-histochemical method we observed ganglia deeper situated in the organ. Thus, although we clearly observed the two trunks and the superficial plexus related by BAKER et al. (1986) in the ferret trachea, the deep nerve plexuses of this specie were not confirmed in Calomys callosus trachea.

The total number of neurons in the tracheal plexus of the Calomys callosus average 279 is slightly superior to those of CHIANG \& GABELLA (1986) in mice trachea (235 in young and 237 in old animals) and less than $10 \%$ from those related by BAKER et al in the ferret trachea. Even so, this number is small when compared with the number of neurons in the enteric plexuses (GABELLA, 1987) but relatively similar as those described in urinary bladder (LIBERTI et al., 1994a) where there are not trully intramural neurons. Comparatively, the neuron perikarya are quite similar in these organs, i.e., 331 in adult guinea-pig urinary bladder and 321 in C57/BLJ mouse (LIBERTI et al, 1994a) and 341 in old mice trachea (CHIANG \& GABELLA, 1978). The mean of neuron perikarya in the trachea is larger than those in the myenteric plexus of guinea-pig small intestine (195 in the duodenum, 185 in the jejunum and 147 in the ileum) (LIBERTI et al., 1994b). The variation of tracheal neuron number between individual mice described by CHIANG \& GABELLA (1986) ranging from 133 to 356 is similar to those we observed 
in Calomys callosus. where the number ranged from 138 to 487 . This variation may be taken as an indication that there is not a tight developmental control of extent of this plexus.

In terms of cell size the tracheal neurons do not form a uniform population. They range in the area of their prolife from about $100 \mu \mathrm{m}^{2}$ to about $600 \mu \mathrm{m}^{2}$ in mice and from $38.37 \mu \mathrm{m}^{2}$ to $805.89 \mu \mathrm{m}^{2}$ in Calomys callosus. Neuronal sizes, however, vary less in the tracheal than in the enteric ganglia (GABELLA \& TRIGG, 1984) and resemble in this respect the ganglia of the head or of the sympathetic chain (SLAVICH, 1932). It is not clear at present whether the variation in size within the population of tracheal neurons reflects different functional specializations, or whether they reflect differences in the extent of their territory of innervation.

From a physiological viewpoint, several structural features of the ganglia may be especially relevant. The ganglia are fully sheathed by a layered capsule or perineurium, and small blood vessels are found within the ganglia, an arrangfement suggesting a separate vascular supply to the ganglia. The ganglion neurons are small and with few processes, as expected in this animal species, and they receive synapses mainly located on short processes. The functional significance of the relatively small number of tracheal neurons cannot be assessed because the role of these neurons and their field of innervation have not been established (however see the studies of CAMERON \& COBURN (1984) and BAKER et al. (1982) on the electrophysiological characteristics of tracheal neurons in ferrets). It should be mentioned that other ganglia are present further down the airways, mainly in association with primary bronchi and also close to the pulmonary veins (HONJIN, 1954, 1956). 


\section{References}

CHIANG, C.H.; GABELLA, G. Quantitative study of the ganglion neurons of the mouse trachea. Cell Tiss. Res., 246:243-252, 1986.

BAKER, D.G.; McDONALD, D.M.; BASBAUM, C.B.; MITCHELL, R.A. The architecture of nerves and ganglia of the ferret trachea as revealed by acetylcholinesterase histochemistry. J. Comp. Neurol., 246: 513-526, 1986.

BAKER, D.G.; HERBERT, D.A.; MITCHELL, RA. Cholinergic neurotransmission in airway ganglia: inhibition by norepinephrine. Phisiologist, 25:225, 1982.

HONJIN, R. On the ganglia and nerves of the lower respiratory tract of the mouse. J. Morphol., 95:263-288, 1954.

HONJIN, R. On the nerve supply of the lung of the mouse, with special reference to the structure of peripheral vegetative nervous system. J. Comp. Neurol., 105:587-625, 1956.

GABELLA, G. Detection of nerve cells by a histochemical technique. Experientia, 25:218-219, 1969.

GABELLA, G. Neuron size and number in the myenteric plexus of the newborn and adult rat. J. Anat., 109:81-95, 1971.

CAMERON, A.R.; COBURN, R.F. Electrical and anatomic characteristics of cells of ferret paratracheal ganglion. Am. J. Phisiol., 246:C450-C458, 1984.

SLAVICH, E. Confronti fra la morfologia di gangli del parasimpatico encefalico e del simpatico cervicale con speciale riguardo alla struttura del ganglio ciliare. $\mathrm{Z}$. Zellforschung, 15:688-730, 1932. 
GABELLA, G.; TRIGG, P. Sizes of neurons and glial cells in the enteric ganglia of mice, guinea-pigs, rabbits and sheep. J. Neurocytol., 13:73-84, 1984.

SMITH, R.V.; TAYLOR, I.M. Observations on the intrinsec innervation of the trachea, bronchi and pulmonary vessels in the sheep. Acta Anat., 80:1-13, 1971.

BARBOSA, A.J.A. Técnica histológica para gânglios nervosos intramurais em preparados espessos. Rev. Bras. Pesq. Med. Biol., 11:95-97, 1978.

RIBEIRO, R.D. New reservoir of Trypanosoma cruzi. Rev. Bras. Biol., 33:429-537, 1973.

GABELLA, G. The number of neurons in the small intestine of mice, guinea-pigs and sheep. Neuroscience, 22(2):737-752, 1987.

WEIGERT, C. Über eine Method zur Färbung elastischer Fasern. Zentralbl. Allg. Pathol. Anat. (Jena), 9:289-292, 1898.

VERHÖFF, F.H. Some new staining methods of wide applicability including a rapid differential stain for elastic tissue. J. Am. Med. Ass. (Chicago), 50:876-877, 1908.

COTTA-PEREIRA, G.; RODRIGO, F.G.; DAVID-FERREIRA, J.F. The use of tannic acid-glutaraldehyde in the study of elastic and elastic-related fibers. Stain Technol., 51:7$11,1976$.

ROMEIS, B. Mikroskopische Technik, 16. Aufl. München, Oldenbourg, 1968. pp. 368389.

JUNQUEIRA, L.C.U.; COSSERMELLI, W.; BRENTANI, R. Differential staining of collagen type I, II and III by Sirius red polarization microscopy. Arch. Histol. Jpn., 41:267-274, 1978. 
JUNQUEIRA, L.C.U.; BIGNOLAS, G.; BRENTANI, R. Picrossirius staining plus polarization microscopy, a specific method for collagen detection in tissue sections. J. Histochem., 1i:447-455, 1979.

KARNOWSKY, M.J.; ROOTS, L.A. "Direct-coloring" Thiocholine method for cholinesterases. J. Histochem. Cytochem., 12:219-221, 1964.

SANTER, R.M.; BAKER, D.M. Enteric neuron number and sizes in Auerbach's plexus in the small intestine of young adult and aged rats. J. Auton. Nerv. Syst., 25:59-67, 1988.

DE-SOUZA, R.R.; MORATELLI, H.B.; BORGES, N.; LIBERTI, E.A. Age-induced nerve cell loss in the myenteric plexus of the small intestine in man. Gerontology, 39:183188, 1993.

LIBERTI, E.A.; QUEIROZ, L.M.; POMPEU, E.; PERITO, M.A.M.; MINARELLI, A.M.; MORAES, J.O.R.; DE-SOUZA, R.R. A quantitative and comparative study of the ganglionic neurons in the myenteric and submucous plexuses of the small intestine, and in the intramural plexus of the gall bladder of the guinea-pig. Rev. Bras. Ciên. morfol., 11(2):106-114, 1994b.

LIBERTI, E.A.; DE-SOUZA, R.R.; PERITO, M.A.M.; ALVES, N.; CHADI, G. Number, size and distribution of ganglion neurons in urinary bladder of rodents. Biol. Res., 27:123128, 1994a. 


\section{Legends}

Figure 1. a- Ganglion of the Calomys callosus trachea ( arrow) in outer surface of the trachealis muscle (m). b- Few elastic fibers (arrows) around and inside the ganglion (n). cSchematic representation of the Calomys callosus trachea (dorsal view) evidencing its intrinsec innervation with two longitudinal trunks (arrows) and a meshwork with many ganglia $(G)$. d- Whole-mount preparation showing ganglia $(G)$ in the two longitudinal trunks (arrows) near the posterior border of the cartilaginous rings (C). e- A single longitudinal nervous trunk is observed (arrow). After its bifurcation (arrowhead) a transverse bundle of fibers is evidenced running to cartilaginous ring (C). $\mathbf{f}-\mathrm{A}$ network of nervous fibers (arrows) are present between the cartilaginous rings (C). $g$ - A thin nervous plexus (arrow) is observed around the vessels of the trachea (V). (a- Picrossirius under polaryzed light, 200X; b- Weigert, 400X; d-g- AChE. d-100X; e- 64X; f, g- 25X).

Figure 2. a- Schematic representation of the ganglion in the six trachea of Calomys callosus. b- A large and elongated ganglion with small, medium and large neurons (arrows). c- A small round ganglion with few neurons (arrows). d- Small (P), medium (M) and large (G) neurons present in a ganglion of the Calomys callosus trachea. e- Neurons of different aspects (arrows) and satellite cells inside a ganglion of Calomys callosus trachea. f- Isolated neuron (arrow) agregated to an nervous bundle $(\mathrm{N})$ of the traqueal plexus. (b- Giemsa, 256 X; c- Giemsa, 400 X; d- NADH-Diaforase, 256 X; e- NADHDIAFORASE, $670 \mathrm{X}$; f- AChE, $400 \mathrm{X}$ ).

Figure 3. Histogram of percentages of neurons with different sizes in the ganglionated plexus of the Calomys callosus trachea.

Table 1. Quantitative data of tracheal ganglia of Calomys callosus. 


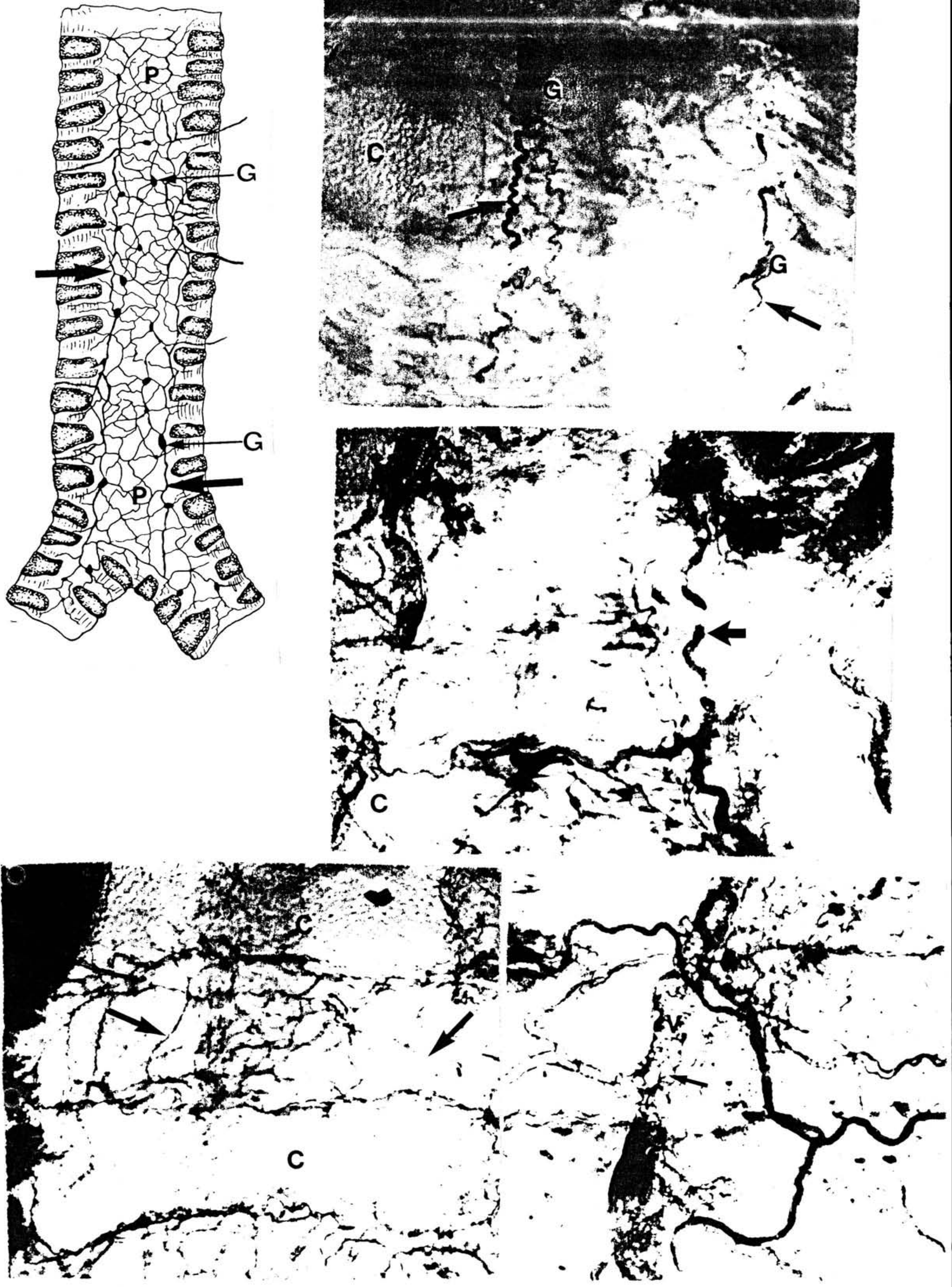


(\%)

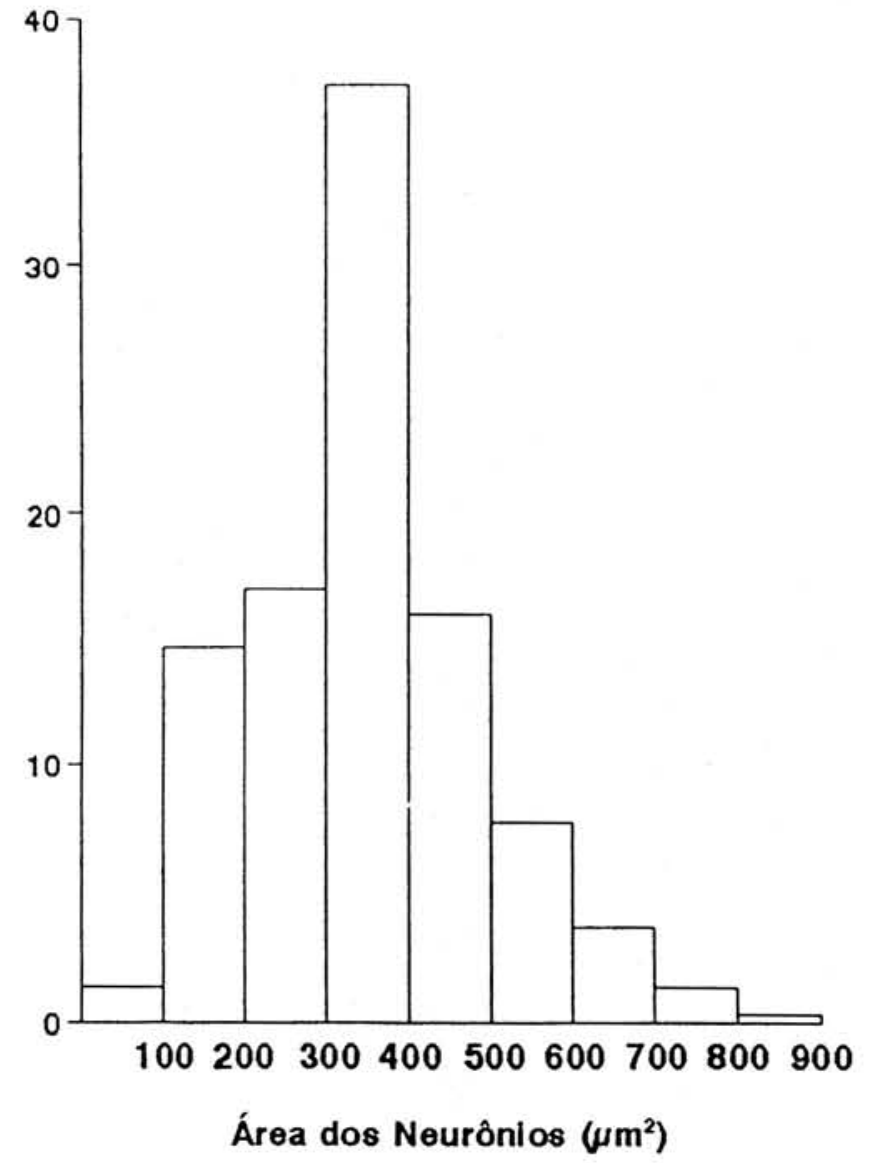

\begin{tabular}{|c|c|c|c|}
\hline Animal & Neurônios/Gânglio & Neurônios & Gânglios \\
\hline $\mathrm{n}^{\circ} 1$ & 14.59 & 248 & 17 \\
\hline $\mathrm{n}^{\circ} 2$ & 20.29 & 487 & 24 \\
\hline $\mathrm{n}^{\circ} 3$ & 11.96 & 323 & 27 \\
\hline $\mathrm{n}^{\circ} 4$ & 12.54 & 138 & 11 \\
\hline $\mathrm{n}^{\circ} 5$ & 13.67 & 164 & 12 \\
\hline $\mathrm{n}^{\circ} 6$ & 17.44 & 314 & 18 \\
\hline Média \pm EPM & $15,08 \pm 1,31$ & $279 \pm 51,80$ & $18,17 \pm 2,60$ \\
\hline
\end{tabular}


TRABALHO XI 
The submucous plexus of Calomys callosus

\title{
QUALITATIVE AND QUANTITATIVE ASPECTS OF THE SUBMUCOUS PLEXUS (MEISSNER) IN THE SMALL AND LARGE INTESTINE OF Calomys callosus.
}

\author{
Nozelmar Borges, Edson Ap. Liberti and Romeu R. De-Souza
}

Departamento de Anatomia do Instituto de Ciências Biomédicas da Universidade de São Paulo. Av. Prof. Lineu Prestes, 2415, Cidade Universitária. CEP 05508-900 - FAX (11) 813-0845, São Paulo, SP - Brasil 


\section{Summary}

The submucous plexus of small and large intestine of Calomys callosus was studied by NADH and AChE histochemical techniques and with TEM and SEM. The neuronal density $\left(\mathrm{n} / \mathrm{cm}^{2}\right)$ was as follows: duodenum, 7,488; jejunum, 5,611; ileum, 2,741; cecum, 3,067, and colon, 3,817 . The neuronal cell profile areas ranged from 36 to $250 \mu \mathrm{m}^{2}$ in the small intestine and from 50 to $820 \mu \mathrm{m}^{2}$ in the large intestine. Most of the neurons displayed a intense $\mathrm{AChE}$ activity in the cytoplasm. AChE-positive nerve fibers were present in a primary meshwork of large nerve bundles and in a secondary meshwork of finer nerve bundles. The neurons were pear-shaped with a round or oval nucleus. The nucleoplasm of the neurons was finely granular with a few condensations of chromatin attached to the nuclear envelope. In the neuropil numerous varicosities filled with vesicles of different size and electron densities were seen. The pre and post-synaptic membrane thickenings were asymmetric. Characteristic glial cells with oval nucleus and few organelles were numerous. The ganglia were small, irregular in shape and covered by fibroblast-like cells. At SEM nerve fibers passed through the circular muscle layer were observed and in the duodenum, they were distributed to the Brunner's gland.

Key words: Enteric nervous system; Submucous plexus; Neuron size; Histochemistry; Ultrastructure; Calomys callosus 


\section{Introduction}

There are many detailed studies on the morphology, numerical extent and histochemical characteristics of the submucous plexus in several mammalian species (Ikeda 1957, Gunn 1968, Stach 1972, Furness \& Costa 1980, Christensen \& Rick 1985, 1987, Gabella 1987, Hoyle \& Burnstock 1989, Morte et al. 1992). However, to our knowledge only one paper is available concerning the submucous plexus of the mouse (Gabella 1987).

The Calomys callosus is a wild rodent commonly found in South America and previously described as harboring Trypanosoma cruzy, the agent of Chaga's disease (Ribeiro, 1973). It is similar in aspect to mouse. Its fur is greet brown and size and weight are also comparable to that of mouse for the first two months, higher weight gain from then on, with maximum weight about $40 \mathrm{~g}$ (Borges et al. 1992). There is growing interest in this animal because it has low susceptibility to infection by the $T$. cruzi. The neurons of the submucous plexus is one of the structures affected by the $T$. cruzi infection. However, studies on the submucous plexus of Calomys callosus are not available in the literature.

The purpose of the present paper is to investigate the neuron number and size, the acetylcholinesterase activity, the fine structure of the submucous plexus in the small and large intestine of Calomys callosus and some of its three-dimensional characteristics by scanning electron microscopy. These data will be used in future investigations on the effects of the experimental infection by $T$. cruzi in the submucous plexus. 


\section{Materials and methods}

Ten male adult Calomys callosus weighing 30 to $35 \mathrm{~g}$. were used. Five animals were sacrificed with an overdose of ether and the following regions of the gut were removed and washed in Krebs solution (Gabella 1969): approximately $4 \mathrm{~cm}$ lengths of the duodenum, mid-jejunum, ileum ( $4 \mathrm{~cm}$ above ileocecal junction), colon and the entire cecum.

Each piece was the ligated with cotton thread at each end and gently distended with Krebs solution which was introduced by the syringe at one end. When sufficient distention had been achieved, the syringe needle was withdrawn and the ligature at that end simultaneously tightened.

The segments where placed under a dissecting microscope and the muscle layers were peeled away with tweezers from large areas, thus exposing the outermost aspect of the submucosa (Gabella 1969).

After being left for $15-30 \mathrm{~min}$. in Krebs solution at room temperature, the segments were transferred to a permeabilizing agent $(0,3 \%$ solution of Triton-X in Krebs solution during 15-90 sec.) and were submitted to 3 changes of Krebs solution for about 10 $\mathrm{min}$. and then incubated for $30-90 \mathrm{~min}$. at $20^{\circ} \mathrm{C}$ in $20 \mathrm{ml}$ of incubation medium containing: Nitro blue tetrazolium (Sigma), $0.5 \mathrm{mg} / \mathrm{ml}$ in distilled water (25 parts), $0.1 \mathrm{M}$ sodium phosphate buffer ( $\mathrm{pH} 7.3$ ) (25 parts), distilled water (50 parts) and B-nicotinamide adenine dinucleotide (reduced form) $0.5 \mathrm{mg} / \mathrm{ml}[10]$.

The development of the reaction was monitored under a dissecting microscope and it was stopped by immersion of the pieces in buffered $10 \%$ formalin, in which they were fixed for a minimum of $24 \mathrm{~h}$. 
Laminar preparations of the pieces were then made as follows: three circular fragments $\left(12.56 \mathrm{~mm}^{2}\right)$ were obtained for each portion of the digestive tract; the submucosa of each fragment was freed of any remaining bundles of musculature and the mucosa scraped away. After several washes in distilled water, the submucosa was picked up on slides and mounted in glycerol; then all the slides were sealed with Entellan (Merck).

The number of ganglion neurons, neurons per ganglion and the profile of nerve cells were obtained by examining the whole-mount preparations under a binocular microscope at magnifications of $400 \mathrm{X}$. All ganglia and neurons present in circular fragments were counted. No ganglia or nerve cell bodies were seen in the esophagus, stomach, distal colon and rectum preparations. The profiles of 300 nerve cell perikarya for each segment of the digestive tract were outlined on drawing paper using a camera lucida attached to the microscope. The areas of these nerve cell bodies were calculated using a digitizing pad. Data were statistically analyzed by the Kruskal-Wallis non-parametric test (Zar 1984) since the distribution of neurons is similar in the four portions studied.

For the histochemical demonstration of acetylcholinesterase the "direct coloring" copper ferrocyanide method (Karnovsky \& Roots 1964) was used in fresh tissues of five animals, prepared as whole-mount stretch preparations.

For transmission electron microscopy, three adult Calomys callosus were used. Fixation was performed by intravascular perfusion of $4 \%$ glutaraldehyde (in $0.1 \mathrm{M}$ phosphate buffer, $\mathrm{pH} \mathrm{7.2)} \mathrm{for} 10 \mathrm{~min}$. The abdomen was opened and small tissue pieces were dissected out from the distal ileum and proximal colon. The specimens were postfixed in phosphate-buffered (0.1 M) OsO4-solution (1\%) for 2 hours, dehydrated with ethanol's and embedded in Araldite. Semithin sections ( $1 \mu \mathrm{m}$ Thick) were stained with $1 \%$ alcoholic 
toluidine blue and examined in the light microscope. Thin sections were cut by diamond knives on an ultramicrotome and stained with lead citrate and uranyl acetate. Electron micrographs were taken on a Philips EM 301.

For scanning electron microscopy five adult Calomvs callosus were used. The fixation was performed as described for transmission electron microscopy and both the small and large intestines were removed. Segments of $2 \mathrm{~cm}$ width were obtained from the middle part of each region opened for removing the mucosa and processed as described by Evan et al. (1976). The segments were then washed in phosphate buffer, dehydrated in an increasing alcohol series, and were critical point dried with liquid CO2 in a Balzers CPD-010 apparatus, gold coated in a Balzers SCS-014 ion sputterer and examined in a JEOL JSMP15 scanning electron microscope.

\section{Results}

\section{Qualitative observations}

Using the NADH diaphorase method (Gabella, 1969) the submucous ganglia were stained, and the neurons were readily recognizable in all whole-mount preparations. The staining technique employed resulted in sharply delimited perikarya and clear visualization of the neuronal nuclei (Fig.1). Any unit of three adjacent nerve cell bodies was considered as a ganglion. In all portions of the digestive tract, a single nerve cell body or a doublet was occasionally found.

The submucous plexus differed in nerve cell density from one portion to another and so the appearance of the plexus also varied. The ganglia were connected with nerve bundles with a very irregular disposition. We were unable to distinguish between the Henle's 
plexus (near the mucosa) and the Meissner's plexus (near the muscle), The gangita were very variable in shape and orientation. They were round, or triangular, or star-like, or ringlike or elongated, or irregular in size and shape (Fig.2).

In the duodenum, jejunum and ileum, the nerve cells were closely packed and in the cecum and colon they were further apart from one another. The neurons were circular in profile, or slightly elongated, in the latter case without a preferential orientation with respect to the length and circumference of the gut (Fig.3).

The AChE histochemical technique showed that the plexus was equally well developed in portions of the gut in which it was present. The nerve cell bodies occurred both in the nodes of the meshwork and in the internodal strands. A secondary meshwork was also seen. Most neurons stain intensely for $\mathrm{AChE}$ while a few stain only moderately (about $85 \%$ of the neurons showed positive reaction for $\mathrm{AChE}$ ). AChE-positive fibers were also observed in a perivascular plexus (Fig. 4).

Under transmission electron microscopy the submucosa in the Calomys callosus intestine was relatively thin and permitted the observation of the elements of both the circular muscle coat and the submucous plexus in the same field in low-power electron micrographs. The presence of neurons and glial cells in close proximity to several axons and their varicosities were observed in the plexus.

The cell bodies of the neurons appeared pear-shaped and they have a large, round or oval nucleus, with one shallow depression in their outline. The nucleoplasm was finely granular with a few condensations of chromatin attached to the nuclear envelope. Ribosome were the most common feature of the cytoplasm, arranged in rosettes in spirals. The cytoplasm contained also aggregations of free ribosome, and small round and oval 
mitochondria. Groups of vesicles and dense bodies were observed, as well as, groups of short flattened Golgi cistern. Bundles of filaments were sometimes found, and microtubules and lysosomes were common.

For the most part, the cell bodies of the neurons and axons were embedded in the infoldings of glial cell cytoplasm. However, small groups of axons ran for short distances in close contact with each other. Along their course, the axons showed fusiform enlargements or varicosities of varying sizes. The axonal profiles contained prominent microtubules, mitochondria, and different types of vesicles. The majority of the neurons had a part of their plasma membrane directly contacting the basal lamina surrounding the entire ganglia.

Glial cells were numerous in the ganglia. Their bodies were generally smaller than those of neurons. In contrast to nerve cells, perikarya of glial cells were poorly equipped with cell organelles. Mitochondria were oval, small with transverse cristae. The nucleus was oval, with deep indentations and large patches of dense material attached to the nuclear envelope. Processes of glial cells branch and spread among the nerve processes and neuron perikarya. Some of then reach the surface of the ganglia. The main features by which glial processes can be identified were: irregularity of shape and the presence of typical mitochondria and gliofilaments and tubules. No myelin sheets were seen.

Inside the submucous ganglia, the axoplasm of the varicosities was filled with vesicles of different size and electrondensity. Three types of vesicles were identified: small electronlucent vesicles, medium-sized granular vesicles, and large granular vesicles. The granular vesicles contained material of light electrondensity located centrally within their 
cores. This material was separated from the investing membrane by a narrow electronlucent zone.

According to the population of vesicles present, three types of varicosities were distinguished: the first type contained predominantly small, round, agranular vesicles. The second type of varicosities contained medium-sized granular vesicles, which, in most cases, were mixed with large numbers of small vesicles. In the third type, the large granular vesicles predominated.

Most vesiculated nerve processes showed the membrane differentiation of typical synaptic junctions. The pre and post-synaptic membrane thickenings were asymmetric, the post-synaptic membrane being more prominent. Synapses on perikarya and dendrites were formed by nerve processes with agranular vesicles and with granular vesicles.

The surface of the ganglion was smooth and a continuous basal lamina surrounds the ganglion. Collagen fibers, fibroblasts, blood vessels, and interstitial space surrounded the ganglion near the basal lamina, but they do not penetrate inside the ganglion (Figs. 5, 6, 7).

Under the scanning electron microscopy, the submucous ganglia were small structures, irregular in shape, and widely spaced. Their connecting nerve strands ran at several angles to the circular muscle, giving raise to a network with roughly triangular, quadrangular or polygonal meshes. Ganglia and connecting strands were extensively covered by fibroblast-like cells. These cells were plate-like, with short processes, which contacted and interlocked with each other. Below the covering of periganglionic fibroblasts, the surface of the plexus was covered by a basal lamina, which gave it a smooth appearance. 
Nerve fibers of the submucosal plexus passed through the circular muscle layer, and in the duodenum, were distributed to the Brunner's gland (Fig. 8).

\section{Quantitative observations}

\section{Neuron counts}

There were considerable variations in the numbers of ganglia and neurons per unit surface area among the organs. From these numbers we computed neuron density per unit surface area (Table I).

\section{Neuron size}

The average neuronal cell size was $123 \pm 86 \mu \mathrm{m}^{2}$ in the duodenum, $156 \pm 73 \mu \mathrm{m}^{2}$ in the jejunum, $166 \pm 94 \mu \mathrm{m}^{2}$ in the ileum, $318 \pm 191 \mu \mathrm{m}^{2}$ in the cecum and $256 \pm 134 \mu \mathrm{m}^{2}$ in the colon (Table I). In the small intestine, the majority of neurons had neuronal cell profile areas (sizes) between $50 \mu \mathrm{m}^{2}$ and $200 \mu \mathrm{m}^{2}$; in the cecum and colon, the majority of neurons had neuronal cell profile areas between $200 \mu \mathrm{m}^{2}$ and $350 \mu \mathrm{m}^{2}$.

\section{Discussion}

The histochemical method used in this investigation was developed for the study of the autonomic ganglia, specially in the gut (Gabella 1969). It stained selectively the neurons in the submucous plexus of the Calomys callosus, leaving the other cell types present in the submucosa unstained or only faintly stained. There was no evidence that some of the submucosal neurons had not been stained and remained undected. Although there was some variation in the intensity of the reaction among the neurons of a ganglion, the reaction appear sd similar in the ganglia of the five parts of the gut examined. 
The pattern of submucosal plexus of the Calomys callosus is quite similar to that of the mice. Ganglia are normally located at the nodes of the plexus and a large number of thin connecting bundles emanated from each of them. As with the submucous plexus of the mice, the meshes of the plexus are short and the ganglia are small (Gabella 1987).

Using the acetylcholinesterase method, a strong $\mathrm{AChE}$ staining was observed within submucous plexus perikarya of the Calomys callosus. The majority of the ganglion neurons stain intensely for $\mathrm{AChE}$. It was also possible to see nerve fibers stained for $\mathrm{AChE}$ in the plexus. This finding is in agreement to that of the gastrointestinal tract of several mammalian species [Taxi 1965, Gunn 1968, Van Driel \& Drukker 1973, Wilson et al. 1981, Furness \& Costa 1983, Hoyle 1989, Morte et al. 1992). The presence of AChE-activity suggests the cholinergic nature of these neurons although AChE-positive neurons need not necessarily be cholinergic since adrenergic and non-cholinergic neurons might display AChE positivity [Eranko et al. 1970, Levey et al. 1983, Seelig et al. 1984). In fact, in the brain it was demonstrated non- cholinergic functions of $\mathrm{AChE}$ and $\mathrm{AChE}$ was present in DOPAminergic nigrostriatal neurons (Greenfield 1985). Furthermore, it was observed neuronal $\mathrm{AChE}$ activity and immunoreactive peptide varicosities simultaneously in the myenteric plexus (Anglade et al. 1988).

The density of nerve cells in the submucous plexus of the mouse has been determined only in small intestine, with 11,300 neurons $/ \mathrm{cm}^{2}$ for the duodenum, 10,285 neurons $/ \mathrm{cm}^{2}$ for the jejunum and 6,300 neurons $/ \mathrm{cm}^{2}$ for the ileum (Gabella 1987). All the values obtained for the small intestine of the Calomys callosus are lower than that observed for the mouse (Gabella 1987). No information is available in the literature about the density of cells in the submucous plexus of Calomys callosus. The data presented here therefore, 
represent the first systematic study that allows comparison of the density of neurons in the submucous plexus of two species of mice.

In general, the neuronal density is higher in small than in the large animal species. The highest density is in small intestine of the mouse, with more than 10,000 submucosal neurons per $\mathrm{cm}^{2}$ of serosal surface, and the lowest density is in the small intestine of the guinea-pig (Gabella 1987); the Calomys callosus has intermediate values.

The data for the Calomys callosus indicate that the ganglion and nerve cell density in the submucous plexus in the duodenum is higher than that of the other portions of the gut and there is a caudal descending gradient in nerve cell density of the submucous plexus along the small intestine. These results are similar to that obtained for the small intestine of mice (Gabella 1987) and for the cat gastrointestinal tract (Christensen \& Rick 1985).

The differences in density of nerve cells in the submucous plexus among organs could correlate with differences in mucosal function (Christensen \& Rick 1985). The relatively dense submucous plexus of the intestine probably is related to the capacity of the intestinal mucosa for peptide secretion as well as to absorptive function. Since the major target of the submucosal ganglia is the mucosa, it is possible that the number of submucosal neurons is related to the decrease in the volume of the mucosa (Gabella 1987).

The size of submucosal neurons in mice has not been investigated previously. In Calomys callosus, the submucosal perikarya cover a wide range of sizes and this is true for all five portions of the gut. A population of small neurons is present in all five portions of its digestive tract, whereas the largest neurons are observed in the large intestine than in the small intestine 
To date, there have been no studies on the fine structure of the submucous plexus of Calomys callosus intestine. The present results showed that the general organization of the plexus is not dissimilar from that described in other species.

Fibroblast-like cells were found in at least six different locations. Little is known about the factors controlling intestinal fibroblast shape and size. The criteria for distinguishing these cell types from one another are at present rather vague, and cells of intermediate appearance can be found (Gabella, 1987). Rather than representing a fixed set of static cell types, it may be that all intestinal fibroblasts have a common origin, and that their dynamic structure and function depends on their local microenvironment (Gabella, 1987).

The enzymatic and hydrolytic microdissection technique, followed by scanning electron microscopy used in the present work proved valuable in providing threedimensional views of the architecture and of the morphology of the submucosal plexus of Calomys callosus intestine.

The role played by nerve cells and glial cells in secreting and maintaining the basal lamina, surrounding the ganglia and connecting nerve strands is unknown. Recent immunohistochemical evidence suggests that the basal lamina of enteric nerves processes combinations of laminin, type-IV collagen, nidogen, heparin sulfate proteoglycan, and fibronectin similar to those of sensory and sympathetic ganglia, but different from that of smooth muscle cells (Bannermann et al., 1986). We were able to observe the basal lamina directly around the submucosal ganglia and the appearance of the basal lamina was similar to that described in other tissues by Sawada $(1981 \mathrm{a}, \mathrm{b})$. 
The resuits of the present study show that the submucous plexus of the mouse

Calomys callosus digestive tract contains a large number of neurons which have different sizes and AChE activities.

\section{References}

Anglade P, Michel C, Ozaki T, Tsuji S, Vignon X, Yanaihara N 1988. Simultaneous localization of acetylcholinesterase activity and met-enkephalin, vasoactive intestinal peptide and substance $\mathrm{P}$ immunoreactivity in the rat myenteric plexus. Histochem $J$ 20: 464-467.

Bannermann PG, Mirsky R, Jessen KR, Timpl R, Duance VC 1986. Light microscopic immunolocalization of laminin Type IV collagen, nidogen, heparan sulphate proteoglycan and fibronectin in the enteric nervous system of rat and guinea pig. $J$ Neurocytol 15: 733-743.

Borges MM, Curi PR, Kloetzel JC 1992. Modulation of parasitemia and antibody response to Trypanosoma cruzi by cyclophosphamide in Calomys callosus (Rodentia, Cricetidae). Rev Inst Med Trop São Paulo 34: 1-8.

Chiang C, Gabella G 1986. Quantitative study of the ganglion neurons of the mouse trachea. Cell Tissue Res 246: 243-252.

Christensen J, Rick GA 1985. Nerve cell density in submucous plexus throughout the gut of cat and opossum. Gastroenterology 89: 1064-1069.

Christensen J, Rick GA 1987. Intrinsec nerves in the mammalian colon: confirmation of a plexus at circular muscle-submucosal interface. J Autonom Nerv Syst 21: 223-231.

Eranko O, Rachardt L, Eranko L, Cunninghan A 1970. Light and electron microscopic histochemical observations on cholinesterase containing sympathetic nerve fibers in the pineal body of the rat. Histochem $J$ 2: 218-219.

Evan AP, Dail WG, Dammrose D, Palmer C 1976. Scanning electron microscopy of cells surfaces following removal of extracellular material. Anat Rec 185: 433-446.

Furness JB, Costa M 1980. Types of nerves in the enteric nervous system. Neuroscience 5: $1-20$.

Furness JB, Costa M, Eckenstein F 1983. Neurons localized with antibodies against choline acetyltransferase in the enteric nervous system. Neurosci lett 40: 105-109.

Gabella G 1969. Detection of nerve cells by a histochemical technique. Experientia, 25: 218-219. 
Gabella G 1987. Structure of muscles and nerves of the gastrointestinal tract, p.355-381. In LR Johnson, Physiology of the Gastrointestinal Tract. Raven Press, New York.

Greenfield SA 1985. Acetylcholinesterase release from dendrites. Neurosci lett 22 (suppl.) S3.

Gunn M 1968. Histological and histochemical observation on the myenteric and submucous plexuses of mammals. J Anat 102: 223-239.

Hoyle CHV, Burnstock G 1989. Neuronal populations in the submucous plexus of the human colon. J Anat 166: 7-22.

Ikeda T 1957. An histological study on the submucous nerve plexus of the alimentary canal with special reference to the three types of nerve plexus. J Comp Neurol 103: 43-53.

Karnovsky MJ, Roots, LA 1964. "Direct-colouring" thiocoline method for cholinesterases. $J$ Histochem Cytochem 12: 19-21.

Levey AI, Wainer BH, Mufson EJ, Mesulan MM 1983. Co-localization of acetylcholinesterase and choline acetyltransferase in the rat cerebrum. Neuroscience 9: $9-22$.

Morte L, Cuervas-Mons,M, Junqueira C, Ramon Y Cajal S 1992. Submucosal plexus of terminal ileum: a study of the cholinergic and noradrenergic nerves in rats with streptozotocin-induced diabetes. Histophathology 7: 11-16.

Ribeiro RD 1973. New reservois of Trypanosoma cruzi. Rev Bras Biol 33: 429-537.

Sawada H 1981a. Scanning electron microscopy of guinea-pig taenia coli. Biomed Res (suppl) 2: 153-158.

Sawada H (1981b. Structural variety of basement membranes: a scanning electron microscopy (SEM) of the plexus submucosus internus (meissner) in the porcine small intestine. Scanning 6: 96-102.

Seelig LL, Doody P, Brainards L, Gidda JS, Goyal RK 1984. Acetylcholinesterase and choline acetyltransferase staining of neurons in opossum oesophagus. Anat Rec 209: 130-135.

Stach W 1972. Der plexus entericus extremus des Dickdarmes und seine Beziehungen zu den interstitiellen Zellen (Cajal). Z Mikrosk Anat Forsch 85: 245-272.

Taxi J 1965. Contribution à l'ètude des conexions des neurones moteurs du systeme nerveus autonome. Am Sci Nat Zool 7: 413-674. 
Van Driel C, Drukker J 1973. A contribution to the study of the architecture of the autonomic nervous system of the digestive tract of rat. J Neural Transm 34: 301-320.

Wilson AJ, Furness JB, Costa M 1981. The fine structure of the submucous plexus of the guinea-pig ileum I. The ganglia, neurons, Schwann cells and neuropil. J Neurocytol 19: 759-784.

Zar J H 1984. Biostatistical analysis. Prentice-Hall, N. Jersey. 

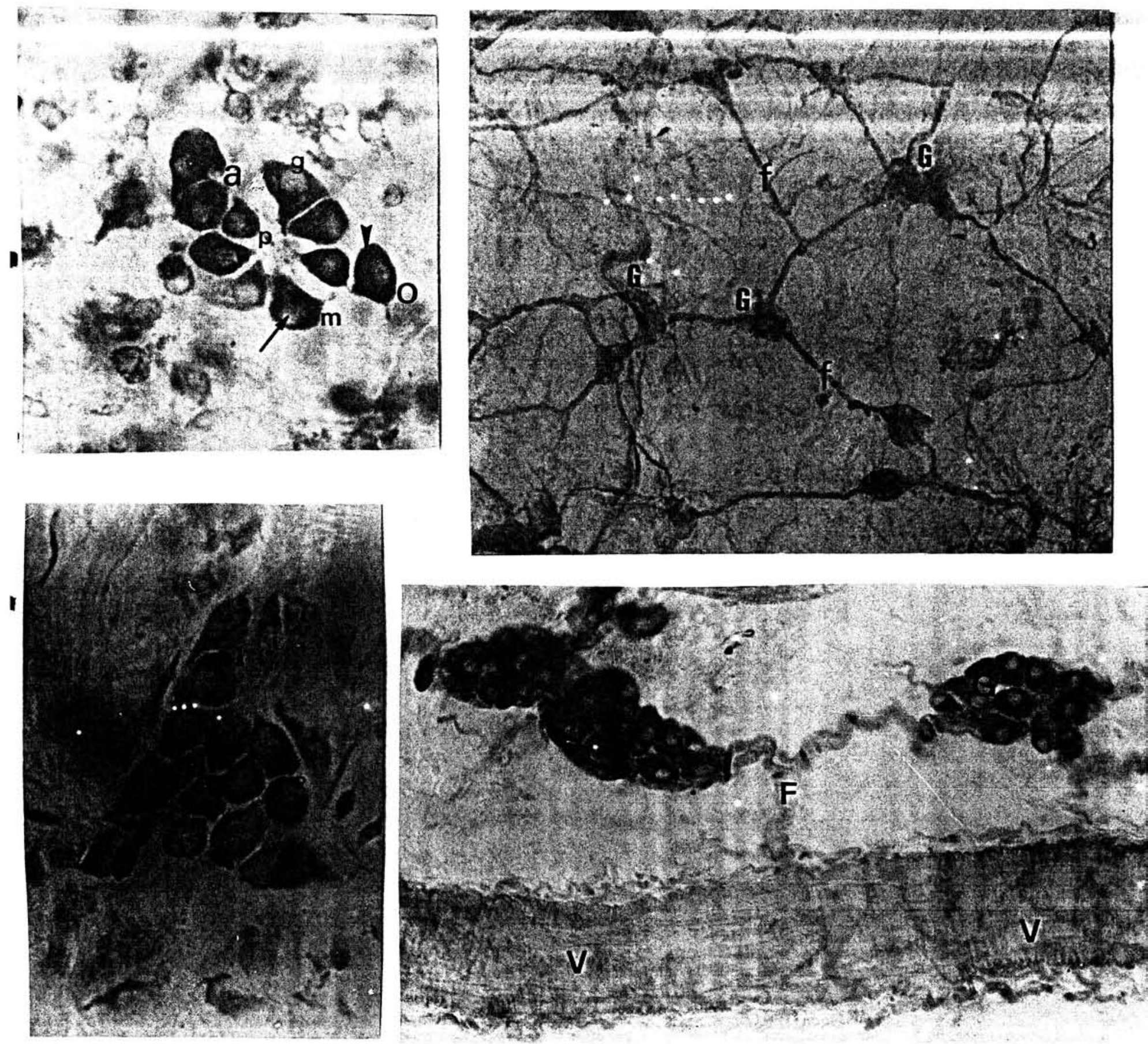

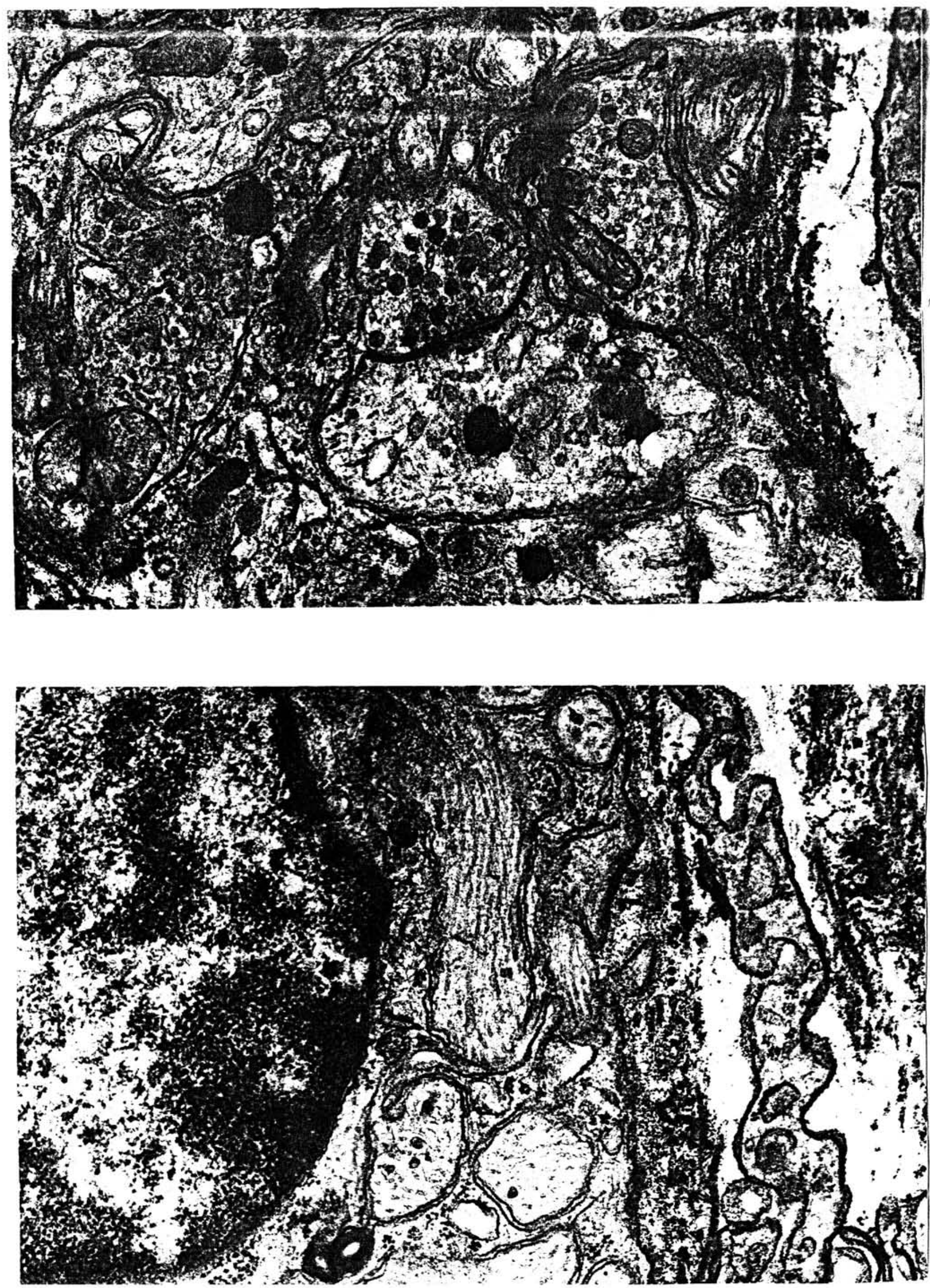

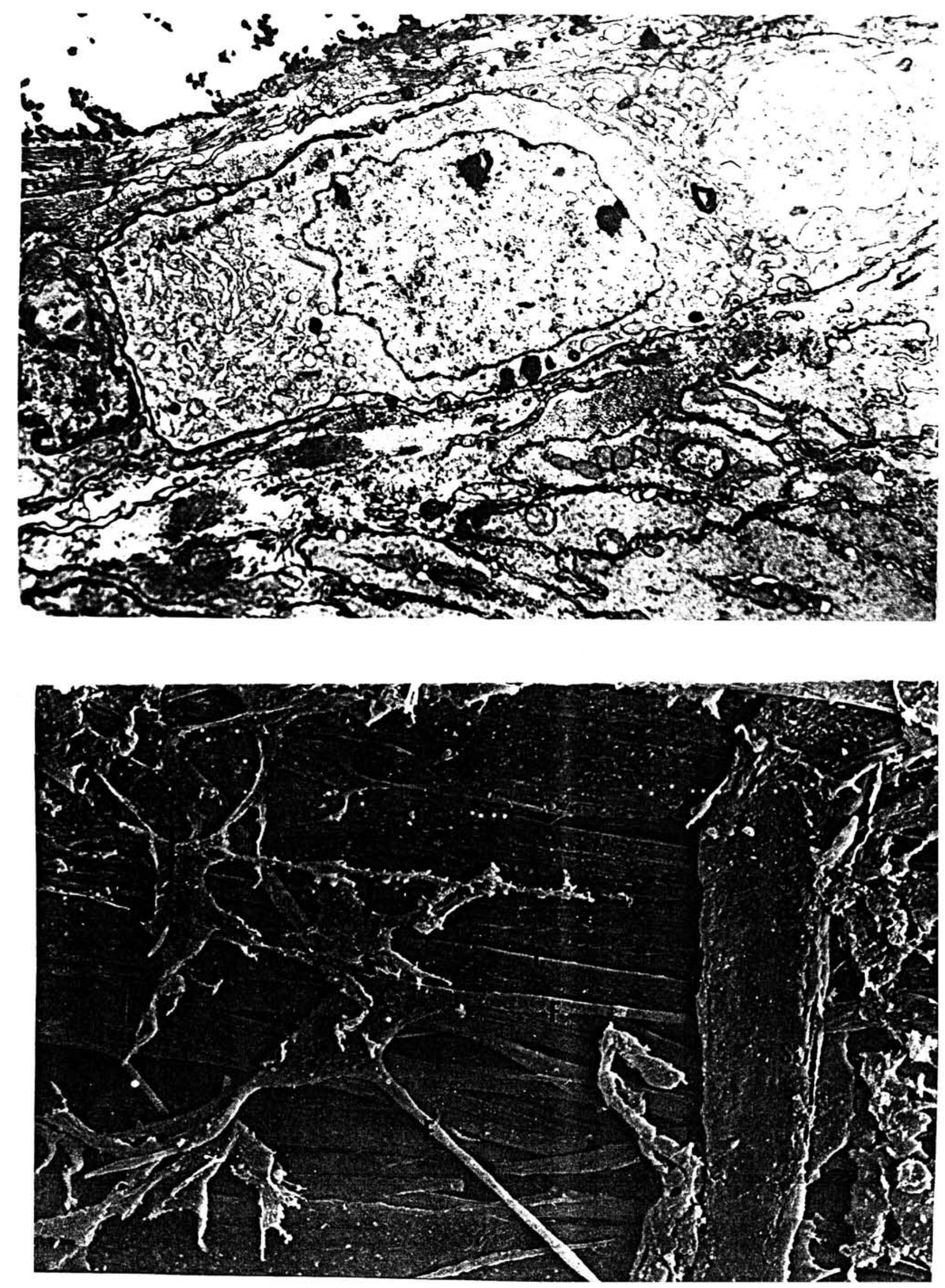


\section{TRABALHO XII}




\title{
Number, size and distribution of ganglion neurons in urinary bladder of rodents
}

\author{
EA LIBERTI, RR DE SOUZA, MAM PERITO, \\ $\mathrm{N}$ ALVES and G CHADI \\ Department of Anatomy, Biomedical Sciences Institute, University \\ of São Paulo, São Paulo, Brazil
}

\begin{abstract}
Whole-mount preparations of urinary bladders stained with a modified Giemsa technique were obtained from three rodent species (Guinea-pig, Calomys callosus and the C57IBLJ isogenic mouse) to identify and estimate the relative number and size of ganglionic neurons within the wall of the organ. The distribution of the ganglia was not uniform among the three species: ganglia were concentrated around the ureteral orifices in the Guinea-pig, they were scattered throughout the organ in Calomys callosus, and they were concentrated near the internal urethral orifice in the C57IBLJ mouse. In the Guinea-pig, the size of approximately 50\% of the neurons lie in thi range of 200 to $300{\mu m^{2}}^{2}$. In Calomys callosus, $40 \%$ of the neurons lie in the range of 200 to $250 \mathrm{\mu m}^{2}$, with $28 \%$ in the range of 50 to $100 \mathrm{um}^{2}$. For the C57/BLJ mouse, approximately $60 \%$ of the neurons have an area of 250 to $400 \mu \mathrm{m}^{2}$.
\end{abstract}

Key words: autonomic nervous system, ganglionic neurons, rodents, urinary bladder.

\section{INTRODUCTION}

The presence of ganglionic neurons within the wall of the urinary bladder has been found in several species, including man (Iwasaki, 1951; Gilpin et al, 1983), dog (Watanabe, 1954) and cat (Feher et al, 1979).

Although in mammals much is known about the general arrangement and histochemistry of the intramural plexus of the urinary bladder (El-Badawi and Schenk, 1966; Ek et al, 1977; Crowe et al, 1986), quantitative data on the neurons such as number and size, are available only for the Guinea-pig urinary bladder. In the urinary bladder of adult Guinea-pigs, counts on whole-mount preparations of entire bladders (Gabella, 1990) reveal the presence of 2000 to 2500 neurons per bladder, either as individual nerve cells or, more frequently, in the form of ganglia containing up to 40 neurons.
In contrast, intramural ganglionic neurons have not been found in the urinary bladders of the rat and mouse, or in the ferret and rabbit, where they occur as a few dozen neurons at most, attesting that the extent of the intrinsic neuronal apparatus of the urinary bladder remains uncertain (Gabella, 1990).

Furthermore, estimates of the number and size of neurons in the urinary bladders of certain important laboratory animals, such as Calomys callosus, are not available in the literature. This animal is a cricetine rodent, similar to a mouse, commonly found in fields of South America, analyzed in some biological aspects as immunology and physiology (Petter et al, 1967; Justines and Johnson, 1970; Mello, 1978), and described in Brazil as harboring Trypanosoma cruzi (Ribeiro, 1973). Data on isogenic mouse C57/BLJ are also lacking.

Correspondence to: Prof Dr Edson Aparecido Liberti, Departamento de Anatomia, Instituto de Ciências Biomédicas, Universidade de Sāo Paulo, Av Prof Lineu Prestes 2415, Bio III - CEP 05508-900, PO BOX 66208 - CEP 05389-970, São Paulo, SP, Brasil. Fax: (55-11) 813-0845. 
In the present study using whole-mount preparations, we intended to estimate the number of ganglia and neurons and their size and distribution in the urinary bladders of three rodent species: the Guinea-pig, $\mathrm{Cal}$ omys callosus and the isogenic mouse (C57) $\mathrm{BLJ})$. These data may be important for future physiological and pathological studies.

\section{MATERIAL AND METHODS}

Three adult Guinea-pigs, three wild mice (Calomys callosus) and three isogenic mice (C57/BLJ) were used. The animals were sacrificed with an overdose of ether and after opening the abdominal wall and cutting the pubic symphysis, the urinary bladder was removed with the distal segment of the ureter and the proximal portion of the urethra. The bladder was filled with Giemsa's fixative solution moderately distending the wall and immersed in the same fixative for 18 hours. It was then opened, the mucosa removed under a dissecting microscope and stained with a modified Giemsa's technique (Barbosa, 1978). Twelve hours later, the whole specimens were dehydrated in an alcohol series, diaphanized with xylene and mounted in resin as stretch or whole-mount preparations.

The numbers of ganglia and neurons were obtained by examining the whole-mount preparations under a binocular microscope at magnifications of 400 and $1000 \mathrm{X}$, respectively. All ganglia and neurons present in each bladder were counted. The profiles of 300 neural perikarya for each species were outlined on drawing paper using a camera lucida attached to a microscope. The areas of these nerve cell bodies were calculated using a digitizing pad and stereometric analysis on a personal computer.

\section{RESULTS}

The intramural neurons were readily identified in all whole-mount preparations of the bladders stained with Giemsa's method. The weakly stained muscle bundles and connective tissue did not obscure the neurons whose cell bodies stained dark blue, revealing very little variation in the staining in- tensity. The staining technique employed resulted in sharply delimited perikarya and clear visualization of the nuclei while the cell processes remained unstained.

The distribution of the ganglia was not uniform in the three species. Thus, in the Guinea-pig, although the ganglia were observed in all the extension of the urinary bladder, they were concentrated around the ureteral orifices. In Calomys callosus, the ganglia were scattered along the organ. In the $\mathrm{C} 57 / \mathrm{BLJ}$ mouse, the ganglia were all concentrated near the urethral orifice. (See Fig 1).

Most of the neuronal cell bodies were circular in profile although some were clongated, with the long axis being twice the short axis (Fig 2A). While several isolated and paired neurons were found in all animals (Fig 2B), most intramural neurons were clustered in circular or elongated ganglia, containing a variable number of nerve cell bodies (Fig 2C-D).

The mean areas of the urinary bladders, the mean number of neurons and the mean number of ganglia obtained from the three species are presented in Table I, together with the mean area of the nerve cell bodies. While 2043 neurons per bladder were seen in the Guinea-pig, they were 1593 in the C57/ BLJ mouse, and only 38 neurons per bladder were found in Calomys callosus.

The areas of the neurons (maximal cellular profiles) in the urinary bladder of the three rodent species are shown in Figure 3 . In the Guinea-pig, neuron area ranges from $100 \mu \mathrm{m}^{2}$ to $400 \mu \mathrm{m}^{2}$, with approximately $50 \%$ of the neurons in the range of $200 \mu \mathrm{m}^{2}$ to $300 \mu \mathrm{m}^{2}$. In Calomys callosus, the neurons range in area from less than $50 \mu \mathrm{m}^{2}$ to cell bodies of $250 \mu \mathrm{m}^{2}$; approximately $40 \%$ of the neurons lie in the range of $200 \mu \mathrm{m}^{2}$ to $250 \mu \mathrm{m}^{2}$, with $28 \%$ in the range of $50 \mu \mathrm{m}^{2}$ to $100 \mu^{2}$. For the isogenic mice (C57/BLJ), the size range extends from $100 \mu \mathrm{m}^{2}$ to 600 $\mu \mathrm{m}^{2}$, with approximately $60 \%$ of the neurons in the range of $250 \mu \mathrm{m}^{2}$ to $400 \mu \mathrm{m}^{2}$.

\section{DISCUSSION}

The stretch or whole-mount preparations have been used to estimate the number of 


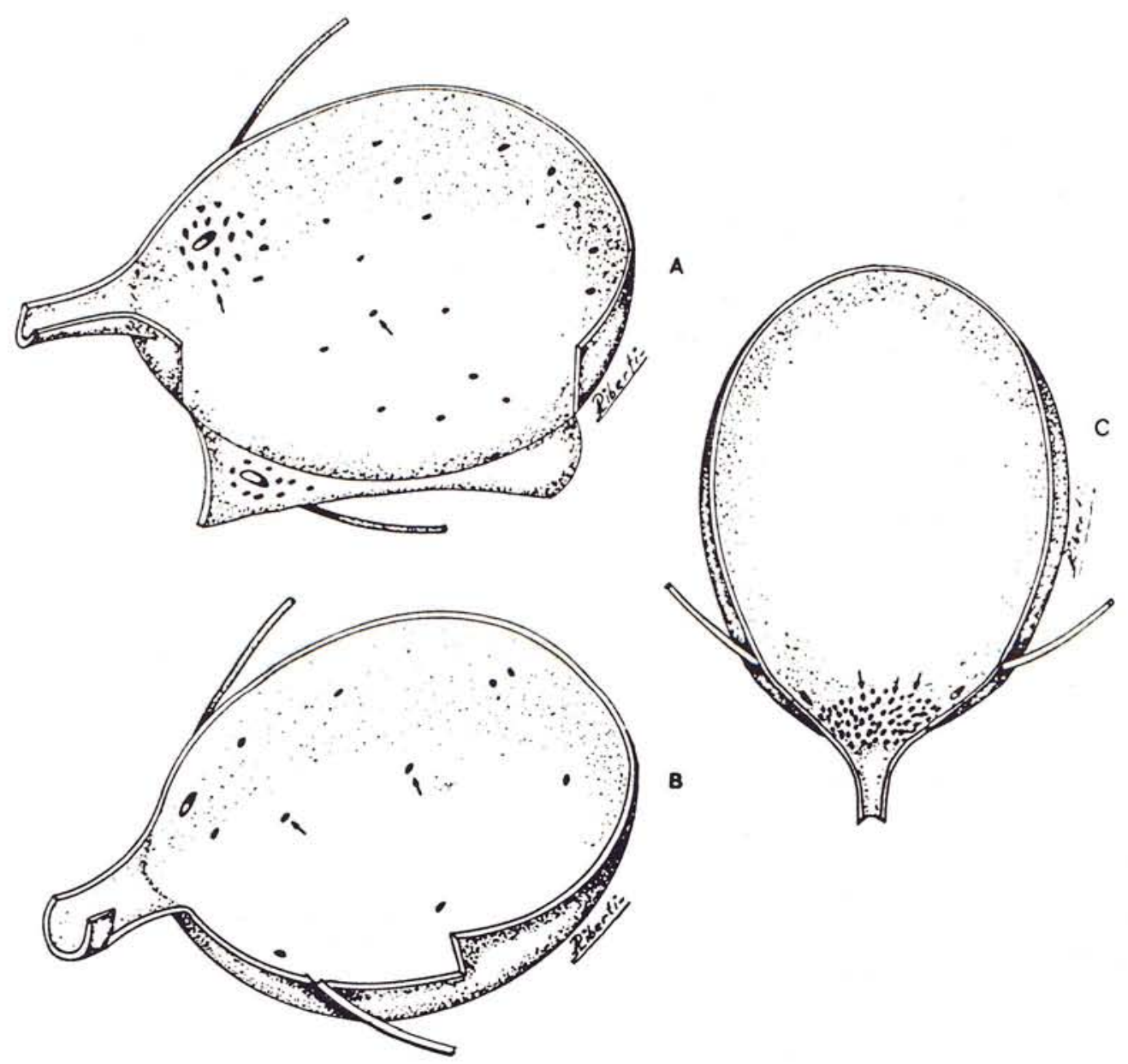

Fig 1. Schematic representation of the ganglia's distribution in the urinary bladder. A. Guinea-pig. B. Calomys callosus. C. C57/BLJ isogenic mouse. In this figure we do not attempt to express the total number of ganglia.

neurons in hollow viscera, as the esophagus (Wells et al, 1987; Kumar and Phillips, 1989), small and large intestines of humans (Murat, 1933; Sternini, 1988; De Souza et $a l, 1993)$, as well as the trachea, gut, gall bladder and urinary bladder of many kinds of animals (Irwin, 1931; Matsuo, 1934; Tafuri, 1957; Ali and McLelland, 1979; Chiang and Gabella, 1986; Gabella, 1987).

The staining method employed to identify ganglionic neurons in whole-mount preparations of the urinary bladder was developed long ago by Barbosa (1978) to study the enteric ganglia and has since been widely used by others investigators (e.g., De Souza et al, 1982, 1988; Ferraz de Carvalho et al, 1983). We found this method suitable for studying the ganglionic plexus in the bladder, because the method selectively stains the nerve cells, leaving others cells unstained or only faintly stained.
Although there is some variation in the intensity of staining among the nerve cells, there is no evidence that any significant number of intramural neurons remained undetected. The cells which stained intensely were undoubtedly neurons owing to their typical morphology. Furthermore, the results of this study confirm those of Gabella (1990) who demonstrated, with the aid of an NADH stain, that the intramural ganglia present in the Guinea-pig urinary bladder contain from 2000 to 2500 neurons per bladder. The staining method we employed resulted in a mean of 2043 neurons for the Guinea-pig bladder.

As seen in the Guinea-pig (Crowe et al, 1986), intramural neurons are also found in the urinary bladder of man (Gilpin et al, 1983) and cat (Feher et al, 1979). However, these types of neurons have not been found in the bladder of the mouse or the rat. In the rabbit and ferret such neurons amount to a 


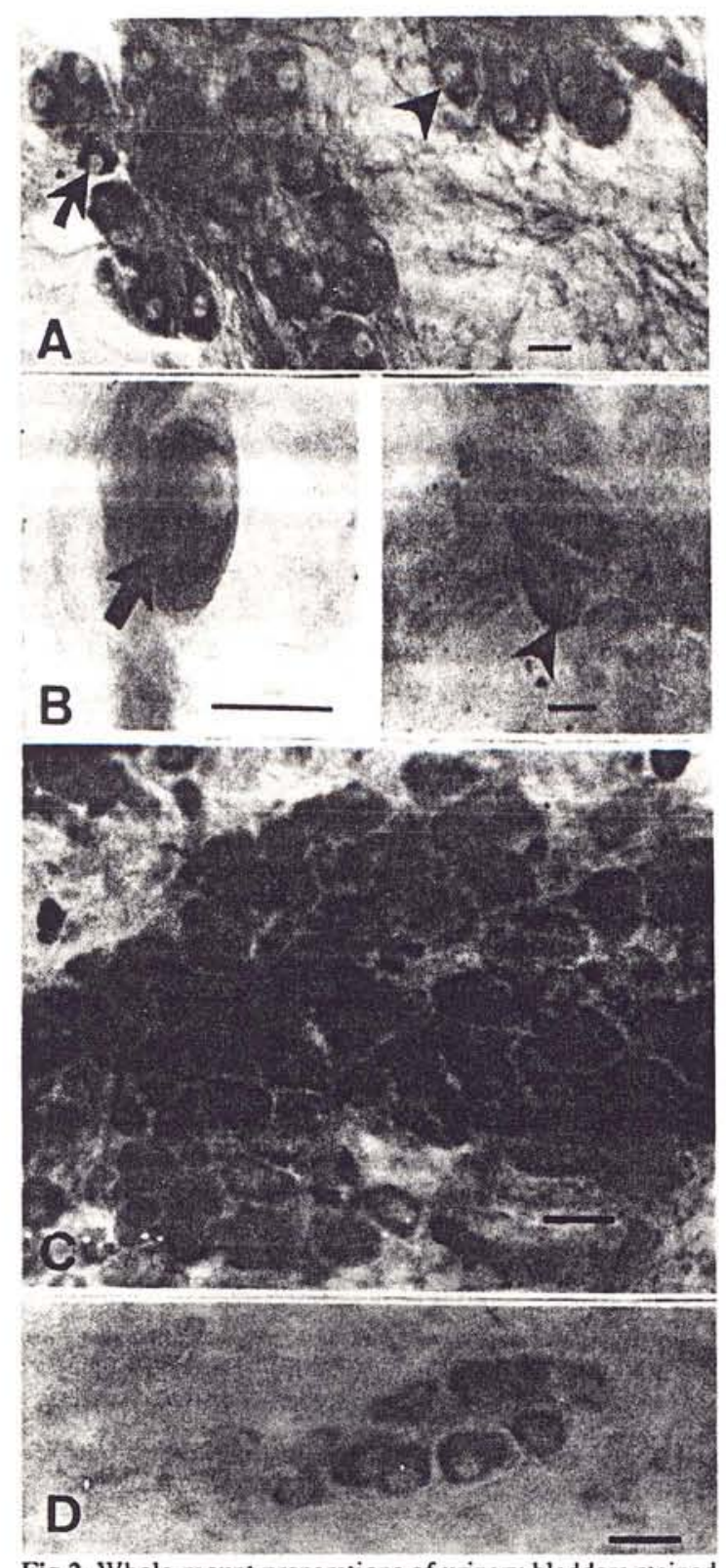

Fig 2. Whole-mount preparations of urinary bladders stained with Giemsa method. A. Ganglion from Guinea-pig with round neuronal cell bodies (arrow) and elongated neuronal cell bodies (arrowhead). Calibration bar $20 \mu \mathrm{m}$. B. Isolated (arrow) and "paired" neurons (arrowhead) from Guinea-pig. Calibration bar, $15 \mu \mathrm{m}$. C. Large ganglion from isogenic mouse C57/BLJ with a large number of neurons. Calibration bar, $20 \mu \mathrm{m}$. D. Small ganglion of Calomys callosus with a small number of neurons. Calibration bar, $20 \mu \mathrm{m}$.

few tens of cells at most (Gabella, 1990). Our results are in partial agreement with these data since the number of neurons was fewer in Calomys callosus than in the Guinea-pig although fairly high in the isogenic mouse (C57/BLJ). These findings corroborate Gabella's (1987) assertion that the packing density of intramural neurons is higher in species of smaller body size.
Ganglia and neurons were present in all the specimens we studied, although their densities were not uniform. Thus, although ganglia and neurons were found in all parts of the Guinea-pig bladder, most were located in the region near the entrance of the ureter. According to Gabella (1990), this area of the bladder is also the point of entry of the two major urinary arteries. The neuronal precursors that colonize the bladder during embryonic life may penetrate this organ by migrating along the vessels. Should this be so, then the distribution of the intramural neurons may reflect aspects of the migratory process of ganglion cells. In Calomys callosus, the few ganglia present were scattered throughout the entire bladder, while in the isogenic mouse (C57/BLJ) despite the abundant ganglia observed, their density was greatest near the internal urethral orifice. The presence of such a concentration of neurons in these regions may be related to control of the local sphincteric mechanism. Relationships of this type are known to occur in several sphincteric regions of the digestive tract (Palumbi, 1933; Indar-Jit, 1951; Damiani and Batistelli, 1956; Lorenz, 1962; Ferraz de Carvalho et al, 1983). Why these differences occur among these three rodents was not evident in the literature until now.

The number of neurons in the urinary bladders of the three rodent species is very low when compared with those seen in the enteric plexus along the digestive tracts of many other animals (Gabella, 1987), including the Guinea-pig and the mouse. Conversely, with the exception of Calomys callosus, the number of neurons is higher than that seen in the tracheal plexus of mice (Chiang and Gabella, 1986).

\section{Table I}

Mean values of urinary bladder area (UBA), total number of :-eurons (TNN), number of ganglia (NG) and neurons area (NA) in three rodent species.

\begin{tabular}{lrrrr}
\hline Species & $\begin{array}{r}\text { UBA } \\
\mathrm{cm}^{2}\end{array}$ & TNN & NG & $\begin{array}{r}\text { NA } \\
\mu \mathrm{m}^{2}\end{array}$ \\
\hline Guinea pig & 2.7 & 2043 & 202 & 331 \\
C57/BLJ mouse & 0.78 & 1593 & 58 & 321 \\
Calomys callosus & 0.65 & 38 & 17 & 148 \\
\hline
\end{tabular}



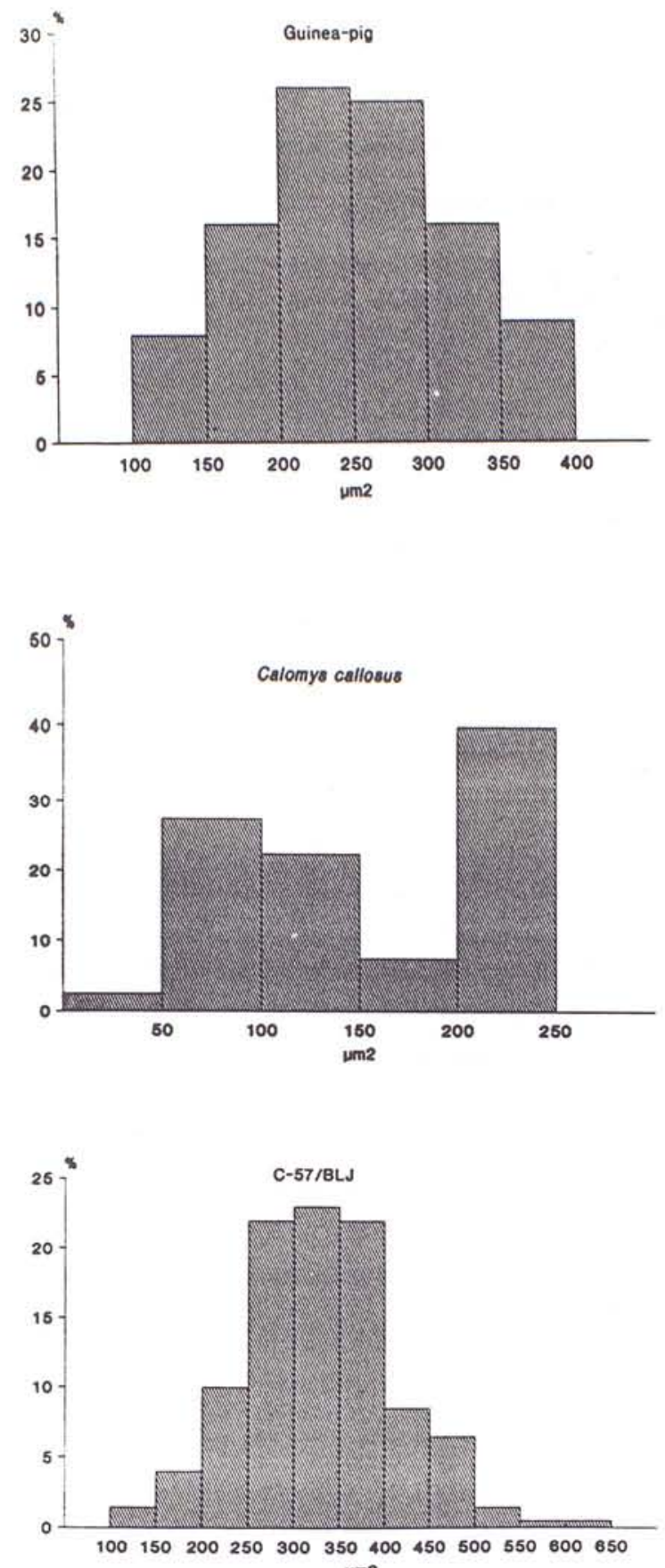

um2

Fig 3. Histograms of percentages of neurons with different sizes in the plexuses of the urinary bladders of Guinea-pig (top), Calomys callosus (middle) and C57/BLJ isogenic mouse (bottom).

In terms of neurons size, the nerve cells of the urinary bladder do not form a uniform population. However, in the Guinea-pig and isogenic mouse (C57/BLJ), the variability in the area shows that the neuron size varies less in the urinary bladder than in the enteric ganglia (Gabella, 1971) and thus resembles the ganglia of the rat tracheal plexus $(\mathrm{Ga}-$ bella and Trigg, 1984). According to Gabella et al (1988), one of the characteristics of nerve cells, and particularly of those whose axons or cell bodies lie outside the CNS, is a large variation in perikaryon size; this variation in size within a population of neurons may be related to different functional specializations or to differences in the extent of their territories of innervation (Chiang and Gabella, 1986).

In the dog (Hamberger et al, 1965) and in the rat (Schulman et al, 1972), the majority of neurons in the urinary bladder plexus shows a positive reaction for acetylcholinesterase, while a minority shows fluorescence for catecholamines. However, little is known of the significance of this variability or of the underlying mechanisms.

\section{REFERENCES}

ALI HA, McLELLAND F (1979) Neuron number in the intestinal myenteric plexus of the domestic fowl (Gallus gallus). Zenbl Vet Med C Anat Histol Embryol 8: 277 283

BARBOSA AJA (1978) Técnica histológica para gânglios nervosos intramurais em preparados espessos. Rev Bras Pesq Med Biol 11: 95-97

CHIANG C, GABELLA G (1986) Quantitative study of the ganglion neurons of the mouse trachea. Cell Tissue Res 246: $243-252$

CROWE R, HAVEN AJ, BURNSTOCK G (1986) Intramural neurons of the Guinea-pig urinary bladder: histochemical localization of putative neurotransmitters in cultures and newborn animals. J Auton Nerv Syst 15: 319-339

DAMIANI R, BATTISTELLI UF (1956) Studio sullo sviluppo embriologico del sistema nervoso intramurale dell'esofago. Arch Ital Anat Embriol 61: 253-277

DE SOUZA RR, FERRI S, FERRAZ-DE-CARVALHO CA PARANHOS CS (1982) Myenteric plexus in a fresh water teleost intestine. I. Quantitative study of nerve cells. Anat Anz 152: 359-362

DE SOUZA RR, FERRAZ-DE-CARVALHO CA, LIBERTI EA, FUJIMURA I (1988) A quantitative study on the myenteric plexus of the distal end of the human esophagus. Gegenbaurs Morphol Jahrb 134: 565-574

DE SOUZA RR, MORATELLI HB, BORGES N, LIBERTI EA (1993) Age-induced nerve cell loss in the myenteric plexus of the small intestine in man. Gerontology 39: $183-188$

EK A, ALM P, ANDERSON KE, PERSSQN CGA (1977) Adrenergic and cholinergic nerves of the human urethra and urinary bladder. A histochemical study. Acta Physiol Scand 99: 345-352

EL BADAWI A, SCHENK EA (1966) Dual innervation of the mammalian urinary bladder. A histochemical study of the distribution of cholinergic and adrenergic nerves. Am J Anat 119: 405-428

FEHER E, CSANYI K, VAJDA J (1979) Ultrastructure of the nerve cells and fibers in the urinary bladder wall of the cat. Acta Anat 103: 109-118

FERRAZ-DE-CARVALHO CA, DE SOUZA RR, OLIVEIRA CA, HAMADA CS, FERNANDES PMP 
(1983) A quantitative study on the myenteric plexus of the distal end of the duodenum and proximal part of the jejunum. Gegenbaurs Morphol Jahrb 129: 51-56

GABELLA G (1971) Neuron size and number in the myenteric plexus of the newbom and adult rat. J Anat 109: $81-95$

GABELLA G (1976) Structure of the Autonomic Nervous System. London: Chapman and Hall

GABELLA G (1987) The number of neurons in the small intestine of mice, Guinea-pig and sheep. Neuroscience 22: 737-752

GABELLA G (1990) Intramural neurons in the urinary bladder of the Guinea-pig. Cell Tissue Res 261: 231237

GABELLA G, TRIGG P (1984) Sizes of neurons and glial cells in the enteric ganglia of mice, Guinea-pigs, rabbits and sheep. J Neurocytol 13: 73-84

GABELLA G, TRIGG P, MCPHAIL H (1988) Quantitative cytology of ganglion neurons and satellite glial cells in the superior cervical ganglion of the sheep. Relationship with ganglia neuron size. J Neurocytol 17: 753-769

GILPIN CJ, DIXON JS, GOSLING JA (1983) The fine structure of autonomic neurons in the wall of the human urinary bladder. J Anat 137: 705-713

HAMBERGER B, NORBERG KA (1965) Adrenergic synaptic terminals and nerve cells in bladder ganglia of the cat. Neuropharmacology $4: 41-45$

INDAR-JIT I (1951) The structure and development of the ileocolic valve and its frenula. Indian J Med Res 44: 361-373

IRWIN DA (1931) The anatomy of the Auerbach's plexus. Am J Anat 9: 11-166

IWASAKI K (1951) Histological studies on the innervation of the bladder in the human embryo. Tohoku Med J 162: 87.94

JUSTINES G, JOHNSON KM (1970) Observation on laboratory breeding of the cricetine rodent Calomys callosus. Lab Anim Care 20: 57-60
KUMAR D, PHILLIPS SF (1989) Human myenteric plexus: confirmation of unfamiliar structures in adults and neonates. Gastroenterology 96: 1021-1028

LORENZ J (1962) Observations comparatives sur l'innervation intramurale du cardia, du pylore et de la valvule ileocoecale chez l'homme normal au cours de l'age. Z Mikrosk Anat Forsch 68: 540-563

MATSUO $H$ (1934) A contribution to the anatomy of Auerbach's plexus. Jap J Med Sci Anat 4: 417.428

MELLO DA (1978) Biology of Calomys callosus (Renger, 1830) under laboratory conditions (RodentiaCricetidae). Rev Bras Biol 38: 807-811

MURAT VN (1933) Sur la question de la cytoarchitectonique des ganglions nerveux de l'intestin de l'homme. Trab Lab Rech Biol Univ Madrid 28: 387-401

PALUMBI G (1933) Differenti aspetti del plesso di Auerbach in regione dei vari segment dell'intestino umano. Rich Morfol 13: 538-562

PETTER F, KARIMI Y, ALMEIDA CR (1967) Un nouveau rongeur de laboratoire, le cricetide Calomys callosus. C R Acad Sc Paris 265: 1974-1976

RIBEIRO RD (1973) Novos reservatórios do Trypanosoma cruzi. Rev Bras Biol 3: 429-537

SCHULMAN CC, DUARTE ESCALANTE O, BOYARSKY S (1972) The uretero-vesical innervation. $\mathrm{Br}$ J Urol 44: 698-712

STERNINI C (1988) Structural and chemical organization of the myenteric plexus. Annu Rev Physiol 50: 81-93

TAFURI WL (1957) Auerbach's plexus in the Guinea-pig. I. A quantitative study of the ganglia and nerve cells in the ileum, caecum and colon. Acta Anat 31: 522-530

WATANABE Y (1954) Histological study on innervation of dog bladder. Arch Histol Jap 7: 311-326

WELLS TR, LANDING BH, ARIEL I, NADORRA R, GARCIA C (1987) Normal anatomy of the myenteric plexus of infants and children. Perspect Pediatr Pathol 1: $152-174$ 


\section{TRABALHO XIII}


ANNALES DES SCIENCES NATURELLES

Zoologie-Biologie animale

UPMC, Case 106

Paris, 28/O2/96

4 place Jussieu

75005 PARIS

FRANCE

Dear Pr Liberti,

I inform you that your manuscript on "Intramural neurons in the urinary bladder...." has been selected for printing in Annales des Sciences naturelles.

I send you the reviewers' comments. Please take account carefully for all corrections in cluding those written in pencil on the manuscript.

I hope you send back soon the definitive version of your manuscript.

With my thanks."

Sincerely yours.

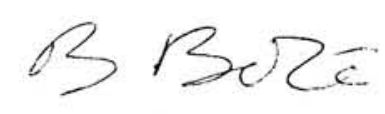

Brigitte Badré

ASN Editorial Board 
INTRAMURAL NEURONS IN THE URINARY BLADDER OF Hoplias s., Rana catesbeiana, Trachemys dorbignyi AND Cavia porcelus. I. A QUANTITATIVE STUDY OF THE NERVE CELLS.

NEURONES INTRAMURALES DANS LES VESSIES de Hoplias Spp., Rana catesbeiana, Trachemys dorbignyi ET Cavia porcelus I. ETUDE QUANTITATIVE DES CELLULES NERVEUSES

\author{
(LIBERTI, E.A.; NOVAES, R.L.C.; BLAZQUEZ, F.J.H.; MINARELLI, A.M.; \\ INTERLIZANO FILHO, W.; DE-SOUZA, R.R.)
}

(Laboratory of Autonomic Neurobiology - Department of Anatomy, Institute of Biomedical Sciences, University of São Paulo - São Paulo, SP - Brazil)

NEURONS IN THE URINARY BLADDER

Correspondence to: Prof. Dr. Edson Aparecido Liberti, Departamento de Anatomia, Instituto de Ciências Biomédicas, Universidade de São Paulo, Av. Prof. Lineu Prestes 2415, Bio III- CEP 05508-900, PO BOX 66208 - CEP 05389-970, São Paulo, SP, Brasil. Fax (55-11) 813-0845 . 
Summary. Whole-mount preparations of urinary bladders stained using a modified Giemsa technique were obtained from Hoplias s., Rana catesheiana, Trachemys dorbignyi and Cavia porcelus to identify and estimate the relative number and area of the ganglionic neurons within the wall of the organ. Neuron distribution, both as individual or paired nerve cells, and as ganglia, was also observed in the four species. The number of neurons $/ \mathrm{cm}^{2}$ was 503 in the fish, 24 in the frog, 12 in the turtle and 818 in the guinea-pig; mean neuron area was $161,485,387$ and $253 \mu \mathrm{m}^{2}$, respectively. The neurons were located within the muscle coat close to muscle fiber bundles and were scattered throughout the organ in Hoplias $s$, Rana catesbeiana, Trachemys dorbignyi. In Cavia porcelus, the neurons were concentrated near the internal urethral orifice.

Key words: Urinary bladder, Autonomic ganglia, Intramural neurons, Cell counts, Autonomic Nervous System

Sommaire: Préparés des lames des vessies teintées avec une technique Giemsa modifiée furent obtenues de Hoplias Spp, Rana catesbeiana, Trachemys dorbignyi and Cavia porcelus pour identifier et évaluer comparativement le nombre relatif et la grandeur des neurones ganglionnaires dedans les parois de l'organe. La distribution des neurones, soit individullement soit dans les pairs des cellules nérveuses ou comme ganglion, fut observée dans les quatre espèces. Le nombre des neurones $/ \mathrm{cm}^{2}$ fut de 503 dans le poisson, 24 dans le crapaud, 12 dans la tortue et 818 dans la cobaye et la grandeur moyenne des neurones fut de $161 \mu \mathrm{m}^{2}, 485 \mu \mathrm{m}^{2}, 387 \mu \mathrm{m}^{2}$ et $253 \mu \mathrm{m}^{2}$, respectivement. Les neurones sont localisés dedans les membranes musculaires et près des faisceaux musculaires et étaient éparpillés par tout l'organe dans Hoplias Spp., Rana catesheiana, Trachemys dorbignyi et concentrés près de l'orifice urétral interne dans Cavia porcelus.

Mots-clés: vessie, ganglions autonomes, neurones, intramurales, enumération des cellules, système nérveux autonome. 


\section{INTRODUCTION}

Although the general arrangement and histochemistry of the intramural plexus of the urinary bladder in mammals is well known (EL-BADAWI \& SCHENK, 1966; EK ef al., 1977; CROWE et al., 1986) quantitative data on the neurons themselves such as number and size are relatively scarce (GABELLA, 1990; LIBERTI et al., 1994a). Very few data are available for other animal groups.

Since the intramural plexus is involved in the innervation of the urinary bladder, controlling the mechanism of micturition, it is of importance to understand neuron morphology and obtain quantitative data in different animal species from diverse environment.

In the present work, we examine the intramural neurons, the number of ganglia and neurons and their size and distribution in the urinary bladder of a fish (Hoplias s.), an amphibian (Rana catesbeiama), a reptile (Trachemys dorbignyi) and a mammal (Cavia porcelus) the presence of. These data are important with regard to for evolutive aspects of the parasympathetic innervation of this organ.

\section{MATERIALS AND METHODS}

Three male Hoplias $s$, weighing 850-1000 g, three Rana catesbeiana weighing 50$60 \mathrm{~g}$ and three Trachemys dorbignyi weighing 90-180 $\mathrm{g}$ were used. The fish were sacrificed using a Benzocaine solution $(70 \mathrm{ppm})$ in acetone $(5 \mathrm{ml})$ added to the water; the frogs were killed by an overdose of ether, and the turtles were decapitated after an injection of Hipnol $\bigotimes$ injection and being held at $-4^{\circ} \mathrm{C}$ for 12 hours. The urinary bladders were removed together with the distal segment of the ureter and the proximal portion of the urethra. They were filled with Giemsa's fixative solution until the wall was moderately distended and immersed in the same fixative for 18 hours. They were then opened, the mucosa removed under a dissecting microscope and stained using a modified Giemsa technique (BARBOSA, 1978). 
Twelve hours later, the complete specimens were dehydrated in an alcohol series, diaphanized with xylene and mounted in resin as stretch or whole-mount preparations.

The numbers of ganglia and neurons present in each bladder were obtained by examining the whole-mount preparations under a binocular microscope at magnifications of 400 and $1000 \mathrm{X}$, respectively. All ganglia and neurons present in each bladder were counted. The profiles of the neural perikarya were outlined on drawing paper using a camera lucida attached to the microscope. The areas of these nerve cell bodies were calculated using a digitizing tablet and stereometric analysis on a personal computer.

The estimates of neuronal density, total number of the neurons and neuron area in the intramural plexus of the urinary bladder in these three species was compared with those published in par a previous study using the same procedure on three male guinea-pigs (Cavia porcelus) weighing 450-550 g (LIBERTI et al., 1994a).

\section{RESULTS}

The longitudinal and circular layers of the muscle coat were not well defined in the fish, frog and turtle urinary bladders. The bundles of muscle fibers are thicker in the fish than in the frog and turtle, and form a network of large lozenge-shaped meshes filled with connective tissue and mucous membrane in these three species. The longitudinal and circular muscle layers are seen with narrow spaces between the constituent muscle bundles in the guinea-pig bladder. Vessels with nerve branches that run within or between the muscle bundles were present in all species (Fig. 1).

Ganglia and paired or isolated neurons were observed throughout the urinary bladder in the four species. They were concentrated around the ureteral orifices in the guinea-pig and scattered throughout the organ in the fish, frog and turtle where they were sometimes partially agglomerated in a non-specific region of the bladder (Fig. 2). Most of the neuron cell bodies were circular in profile although some were elongate, the long axis being twice 
the short axis. Isolated and/or paired neurons were found in all the species although their number was reduced in the guinea-pig. The ganglia were small and mainly round in shape in Trachemys dorbignyi with an elongated appearance in Hoplias $s$, and Rana catesbeiana. They were densely packed and variable in shape in Cavia porcelus (Fig.3).

The mean numbers of neurons per bladder $(\mathbf{N})$, isolated and/or paired neurons $(\mathbf{I} / \mathbf{P})$, neurons $/ \mathrm{cm}^{2}\left(\mathrm{~N} / \mathrm{cm}^{2}\right)$, ganglia $(G)$, ganglia $/ \mathrm{cm}^{2}\left(\mathrm{G} / \mathrm{cm}^{2}\right)$ and neurons/ganglion $(\mathrm{N} / \mathrm{G})$ obtained from the four species are presented in Table I, together with the mean area of the nerve cell bodies (NA).

The areas of the neurons (maximum cellular profiles) in the urinary bladder of the four species are shown in Figure 4. In Hoplias s., neuron area of the perikarya ranges from 50 to $400 \mu \mathrm{m}^{2}$ with most of the neurons in the range of 100 to $200 \mu \mathrm{m}^{2}$. The variation in neuron area is large in Rana catesbeiana ranging from 150 to $1000 \mu \mathrm{m}^{2}$, and in Trachemys dorbignyi where perikarya area ranges from 50 to $900 \mu \mathrm{m}^{2}$. Thus, the area of most of the population of the neuron perikarya lies in the wide range of from 300 to $550 \mu \mathrm{m}^{2}$ in the frog and from the 250 to $500 \mu \mathrm{m}^{2}$ in the turtle. In Cavia porcelus, the area of the neuron perikarya ranges from 100 to $400 \mu \mathrm{m}^{2}$ with approximately $50 \%$ of the neurons lying in the range of 200 to $300 \mu \mathrm{m}^{2}$.

\section{DISCUSSION}

Whole-mount preparations have been used to estimate the number of neurons in hollow viscera like the digestive tract, trachea, gall bladder and urinary bladder of many kinds of animals (WELLS et al., 1987; KUMAR \& PHILLIPS, 1989; MURAT, 1933; STERNINI, 1988; DE SOUZA et al., 1993; IRWIN, 1931; MATSUO, 1934; TAFURI, 1957; ALI \& McLELLAND, 1979; CHIANG \& GABELLA, 1986; GABELLA, 1987; GABELLA, 1990; LIBERTI et al., 1994a, b). 
The non-histochemical method developed by BARBOSA (1978) and employed to identify ganglionic neurons in whole-mount preparations of the urinary bladder has been widely used (e.g. DE SOUZA et al., 1982, 1988, 1993; FERRAZ DE CARVALHO et al., 1983; LIBERTI et al., 1994a, b; MECIANO FILHO et al., 1995) because it selectively stains the nerve cells, leaving others cells unstained or only faintly stained. Furthermore, the results previously described for the guinea-pig (LIBERTI et al., 1994a) confirm those obtained by GABELLA (1990) employing a histochemical method in the same animal species.

Intramural ganglionic neurons are indeed present in the urinary bladder of the four species studied as also seen in the urinary bladder of man (GILPIN et al., 1983) and the cat (FEHER et al., 1979) where their number is unknown (GABELLA, 1990). The data from the frog and turtle urinary bladders are in agreement with those observed by GABELLA (1990) in the rabbit and ferret and with those for the rodent Calomys callosus reported by LIBERTI et al. (1994a) where these neurons number a few tens of cells at most in contrast to their absence in the rat and mouse (GABELLA, 1990).

The number of neurons in the guinea-pig urinary bladder is high. When compared with other rodent species such the rat and mouse where they are absent, and Gerbillus gerbillus and Jaculus jaculus (MOSTAFA et al.,1975) and C57/BLJ isogenic mice (LIBERTI et al., 1994a) where many ganglia were observed, great variability in species of the same order is seen. Thus, the innervation of the bladder is specific for each group and depends on intrinsic factors which make it impossible to establish a general pattern of innervation for animals of the same family. This assertion is true for the frog where the results for Rana catesbeiana contrast with those of McLEAN et al. (1966) for Rana temporaria, in which large number of ganglionic neurons is observed near the neck of the urinary bladder. It is also probably true for the turtle, although data were not available for other reptilian species. 
Neuron density was not uniform; however, ganglionic neurons were more abundant near the points of entry in the guinea-pig bladder. According to GABELLA (1990), this area of the bladder is also the point of entry of the two major urinary arteries; the neuronal precursors that colonize the bladder during embryonic life may penetrate this organ by migrating along the vessels. Should this be so, then the distribution of the intramural neurons may reflect aspects of the migratory process of the ganglion cells. However, if the intramural neurons are more concentrated near the neck of the urinary bladder, as in Rana temporaria (McLEAN et al., 1966) and the C57/BLJ mouse (LIBERTI et al., 1994a) the presence of such a concentration of neurons in this region may be related to control over the local sphincter mechanism. Relationships of this type are known to occur in several sphincter regions of the digestive tract (PALUMBI, 1933; INDAR-JIT, 1951; DAMIANI \& BATISTELLI, 1956; LORENZ, 1962; FERRAZ DE CARVALHO et al., 1983).

The intramural ganglia in Cavia porcelus are variable in shape and different from those of the other species studied. They resemble those of the myenteric plexus of the sheep small intestine and the guinea-pig duodenum (GABELLA, 1987; LIBERTI et al., 1994b).

The intramural ganglia in Hoplias s., Rana catesbeiana and Trachemys dorbignyi are similar in morphology to the submucous ganglia of the guinea-pig small intestine (GABELLA, 1987; LIBERTI et al., 1994b) and the intramural plexus of the gall bladder (SCHABADASCH, 1930; OHKUBO, 1936b; GUNN, 1968; GABELLA, 1979; CAI \& GABELLA, 1983a). These characteristics may be related to the loosely arranged muscle fibers in the urinary bladders of the former species that resemble the muscle arrangement in the gall bladder similar to the muscularis mucosae of the digestive tract innervated by the submucous plexus (CAI \& GABELLA, 1983b).

In terms of neuron area, the nerve cells do not constitute a uniform population. According to GABELLA et al. (1988), one of the characteristics of nerve cells, and particularly of those whose cell bodies lie outside the CNS, is large variation in perikaryon size. This variation in size within a population of neurons may be related to different 
functional specialization or to differences in the extent of their territories of innervation (CHIANG \& GABELLA, 1986).

As noted above, the intramural plexus of the urinary bladder is quite different in various groups of similar or different species, confirming the difficulty to establish a species specific pattern.

According to GABELLA (1990), the extent of the intrinsic neuronal apparatus of the bladder remains uncertain and further studies leading to a better understanding of the environment and behavior of the species are necessary to comprehend the significance of this variability and of the underlying mechanisms.

\section{CONCLUSIONS}

Intramural neurons were present in the urinary bladders of all species

-The neurons were scattered throughout the organ in the fish, frog and turtle and concentrated near the internal urethral orifice in the guinea-pig

-The number of neurons per unit area was higher in the fish and guinea-pig than in the frog and turtle urinary bladders

-The mean area of the neurons was higher in the frog and turtle than in the fish and guinea pig

-The intramural plexus of the urinary bladder is quite different in groups of similar and different species

ACKNOWLEDGEMENTThe authors wish to thank Mr. A.E. Pinuela for photographic assistance. 


\section{FIGURES}

1- Muscle arrangement in the urinary bladders of Hoplias s. (a), Trachemys dorbignyi (b) and Rana catesbeiana (c) urinary bladders. Nerve branches $\left(^{*}\right)$ and ganglionic neurons (arrows) are seen among the muscle bundles (M) in the urinary bladders of Hoplias s. (d), Cavia porcelus (e), Trachemys dorbignyi (f) and Rana catesbeiana (g). (Whole-mount preparations, Giemsa technique. a- 40X; b- 64X; c, d, e, f- 250X; g- 170X.)

1. Arrangement musculaire dans les vessies de Hoplias Spp. (a), Trachemys dorbignyi (b) et Rana catesbeiana (c) vessies. Vaisseaux (grandes flèches) Rameaux nerveux (*) et neurones ganglioniques (flèches) sont évidents parmi le faisceaux musculaires $(\mathrm{M})$ dans les vessies de Hoplias Spp. (d), Cavia porcelus (e), Trachemys dorbignyi (f) et Rana catesbeiana (g). (Préparés, technique Giemsa. a-40X; b- 64X; c, d, e, f- 250X; g- 170X).

2- (a) Ganglionic neurons scattered throughout the urinary bladder of Hoplias s. (arrows). In Rana catesbeiana (b) and Trachemys dorbignyi (c) the neurons are partially agglomerated in a non-specific region of the bladder (Giemsa technique, a- 100X; b- 430X; c- 250X). d-Schematic representation of neuronal density in the urinary bladders of the four species (I- Hoplias s., Rana catesbeiana and Trachemys dorbignyi; II- Cavia porcelus).

2. (a) Neurones ganglioniques éparpillés au long de la vessie de Hoplias Spp. (flèches). Dans Rama catesbeiana (b) et Trachemys dorbignyi (c), ils étaient partiellement agglomerés dans une région non-spécifique de la vessies (technique Giemsa, a- 100X; b- 430X; c- 250X). d - Réprésentation schématique de la densité neuronelle dans les vessies des quatre espèces (I - Hoplias Spp, Rana catesbeiana, Trachenys dorbignyi; II - Cavia porcelus). 
3. Isolated, paired or ganglionic neurons in the urinary bladders of the four species. A capsule can be seen around the ganglion (arrows). (a, e-Hoplias s; b, g-Rana catesbeiana; c, f- Trachemys dorbignyi; d, h- Cavia porcelus). (Giemsa technique, a, b, e, g- 430X; c, h- 250X; d- 700X; f- 600X).

3. Neurones isolés, en pairs ou ganglionnés dans vessies des quatre espèces. Une capsule est évidente autour du ganglion (flèches). (a, e - Hoplias Spp; b, g-Rana catesbeiana; c, f Trachemys dorbignyi; d, h-Cavia porcelus). (Technique Giemsa, a, b, e, g- 430X; c, h250X; d- 700X; f- 600X).

4. Ranges in perikaryon area in the intramural plexus of the urinary bladder in Hoplias $s$. (a), Rana catesbeiana (b), Trachemys dorbignyi (c) and Cavia porcelus (d).

4.Variations de l'aire du perikarion de plexus intramural de la vessie dans Hoplias s. (a), Rana catesbeiana (b), Trachemys dorbignyi (c) and Cavia porcelus (d).

Table I. Mean values for the total number of neurons (N), isolated and/or paired neurons (V/P), neurons $/ \mathrm{cm}^{2}\left(\mathrm{~N} / \mathrm{cm}^{2}\right)$, total number of ganglia $(\mathrm{G})$, ganglia/ $\mathrm{cm}^{2}\left(\mathrm{G} / \mathrm{cm}^{2}\right)$, neurons/ganglion (N/G) and neuron area (NA) in the four species.

Tableau I. Valeur moyenne du numéro total des neurones $(\mathbf{N})$, isolées et/ou neurone en pairs (I/P), neurone $/ \mathrm{cm}^{2}\left(\mathbf{N} / \mathrm{cm}^{2}\right)$, numéro total des ganglions (G), ganglions $/ \mathrm{cm}^{2}$

$\left(G / \mathbf{c m}^{2}\right)$, neurones/ganglion (N/G) et aire neuronale (NA) dans le quatre espéces. 

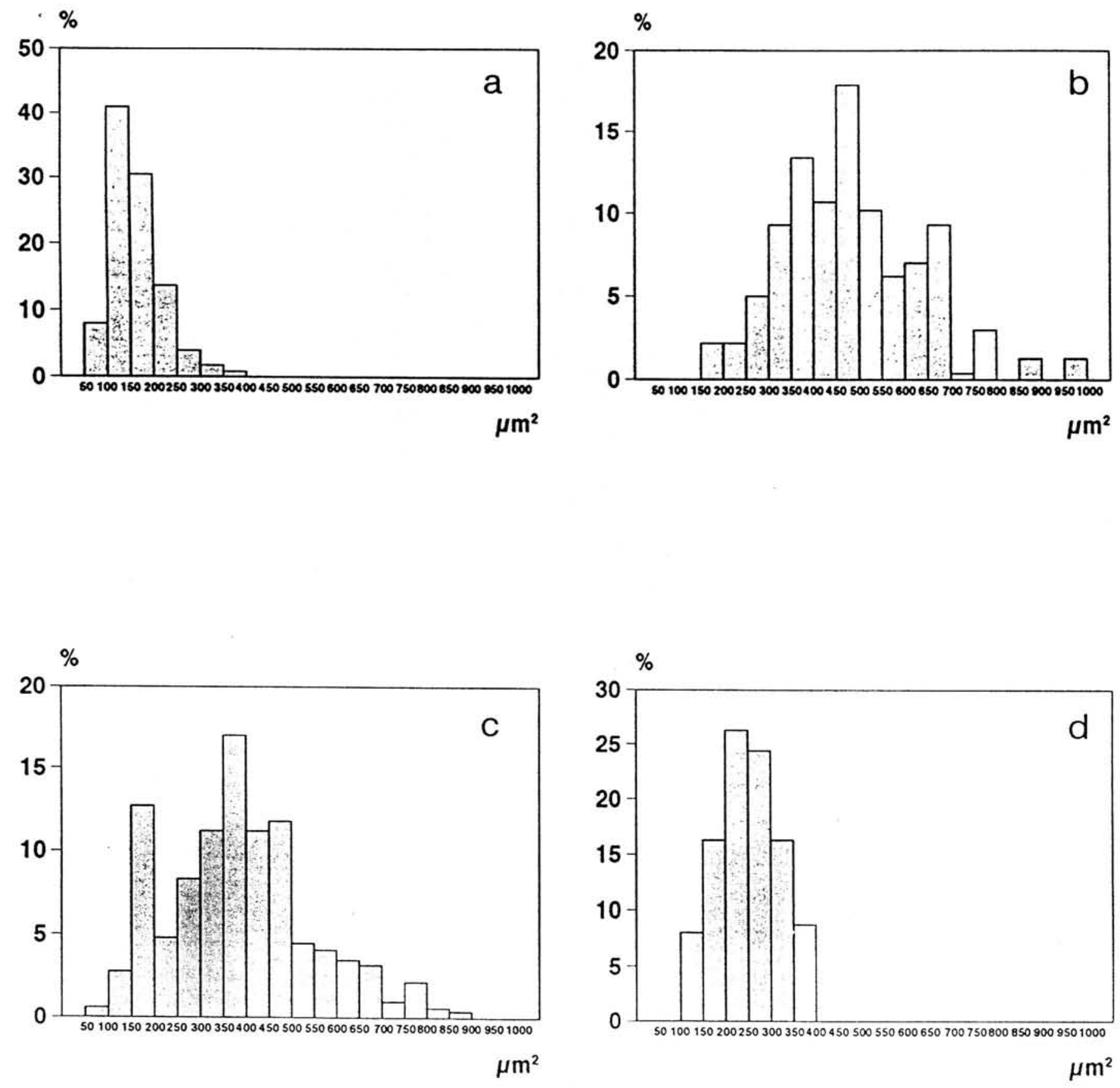


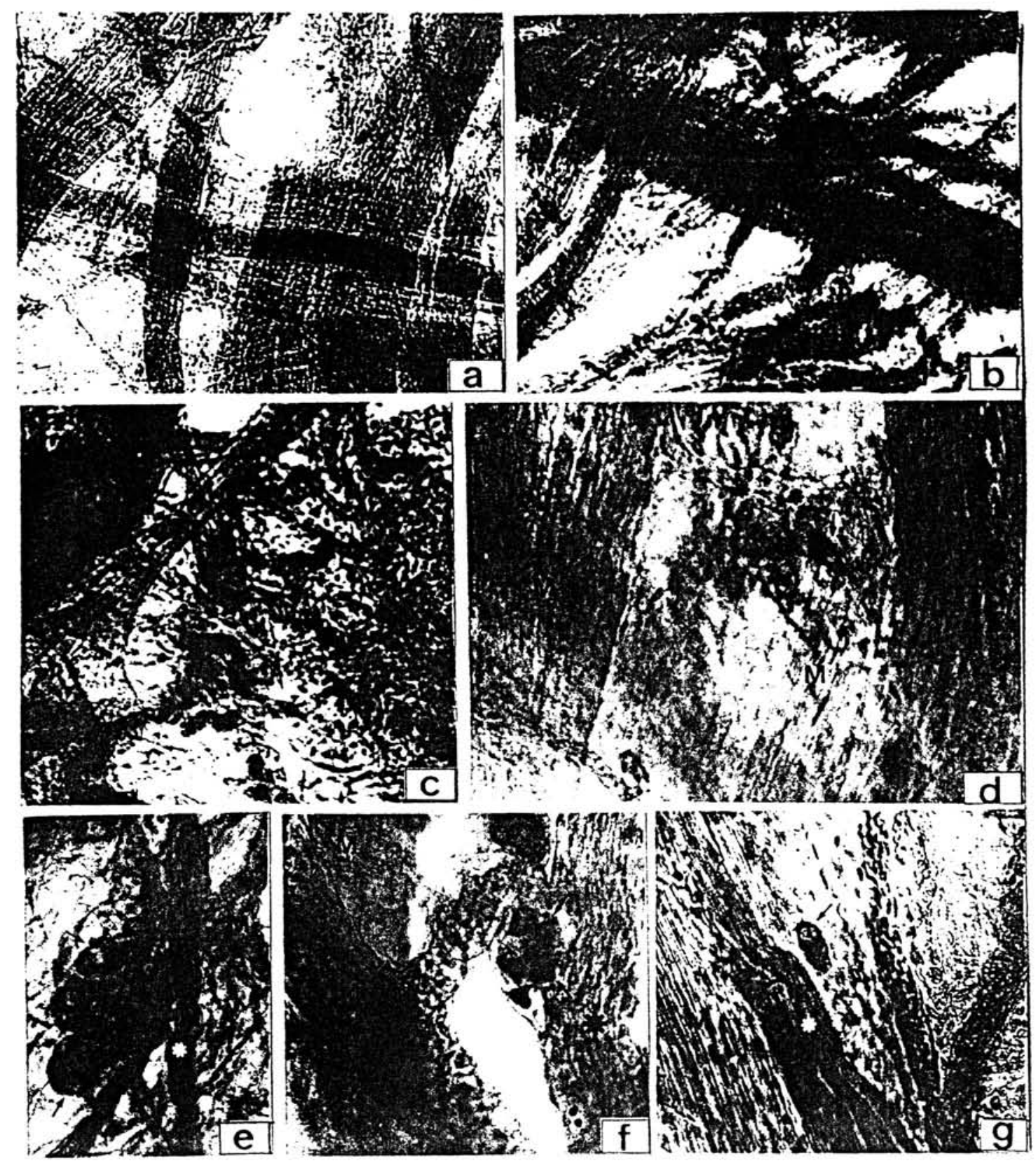




\section{REFERENCES}

ALI, H.A., MCLLELLAND, J., 1980. Variations in the neuron size in avian intestinal myenteric plexus. Anat. Anz., 147: 348-353.

BARBOSA, A.J.A., 1978. Técnica histológica para gânglios nervosos intramurais em preparados espessos. Rev. Bras. Pesq. Méd. Biol., 11: 95-97.

CAI, W.Q., GABELLA, G., 1983a. Innervation of the gall bladder and biliary pathways in the guinea-pig. J. Anat., 136: 97-109.

CAI, W.Q., GABELLA, G., 1983b. The musculature of the gall bladder and biliary pathways in the guinea-pig. J. Anat., 136: 237-250.

CHIANG, C.H., GABELLA, G., 1986. Quantitative study of the ganglion neurons of the mouse trachea. Cell Tissue Res., 168: 475-488.

CROWE, R, HAVEN, A.J., BURNSTOCK,G., 1986. Intramural neurons of the guinea-pig urinary bladder: histochemical localization of putative neurtransmitters in culture and newborn animals. J. Auton. Nerv. System, 15: 319-339.

DAMIANI, R., BATTISTELLI, U.F., 1956. Studio sullo sviluppo embriologico del sistema nervoso intramurale dell'esofago. Arch. Ital. Anat. Embriol., 61: 253-277.

DE-SOUZA, R.R., FERRI, S., FERRAZ-DE-CARVALHO, C.A., PARANHOS, G., 1982. Myenteric plexus in a fresh water teleost intestine. I. Quantitative study of nerve cells. Anat. Anz., 152: 359-362.

DE-SOUZA, R.R., FERRAZ-DE-CARVALHO, C.A., LIBERTI, E.A., FUJIMURA, I., 1988. Quantitative study on the myenteric plexus of the distal end of the human esophagus. Gegenbaurs Morphol. Jahrb., 134: 565-574.

DE-SOUZA, R.R., MORATELLI, H.B., BORGES, N., LIBERTI, E.A., 1993. Age-induced nerve cell loss in the myenteric plexus of the small intestine in man. Gerontology, 39: 183-188.

EL-BADAWI, A., SCHENK, E.A., 1966. Dual innervation of the mammalian urinary bladder. A histochemical study of the distribution of cholonergic and adrenergic nerves. Am. J. Anat., 119: 405-428.

EK, A., ANDERSON, K.E., PERSSON, C.G.A., 1977. Adrenergic and cholinergic nerves of the human urethra and urinary bladder. A histochemical study. Acta Physiol. Scand., 99: 345-352. 
FEHÉR, E., CSÁNYI, K., VAJDA, J., 1979. Ultrastructure of the nerve cells and fibers in the urinary bladder wall of the cat. Acta Anat., 103: 109-118.

FERRAZ-DE-CARVALHO, C.A., DE-SOUZA, R.R., OLIVEIRA, C.A., HAMADA, G.S., FERNANDES, P.M.P., 1983. A quantitative study on the myenteric plexus of the distal end of the duodenum and the proximal part of the jejunum. Gegenbaurs Morphol. Jahrb., 129: 51-56.

GABELLA, G., 1979. Innervation of the gastrointestinal tract. Rev. Cytol., 59: 129-193.

GABELLA, G., 1987. The number of neurons in the small intestine of mice, guinea-pigs and sheep. Neuroscience, 22:737-752.

GABELLA, G., TRIGG, P., MCPHAIL, H., 1988. Quantitative cytology of ganglion neurons and satellite glial cells in the superior cervical ganglion of the sheep. Relationship with ganglia neuron size. J. Neurocytol, 17: 753-769.

GABELLA, G., 1990. Intramural neurons in the urinary bladder of the guinea-pig. Cell Tissue Res., 261: 231-237.

GILPIN, C.J., DIXON, J.S., GILPIN, S.A., GOSLING, J.A., 1983. The fine structure of the wall of the human urinary bladder. J. Anat., 137: 705-713.

GUNN, M., 1968. Histological and histochemical observations on the myenteric and submucous plexuses of mammals. J. Anat., 102: 223-239.

INDAR-JIT, I., 1951. The structure and development of the ileocolic valve and its frenula. Indian J. Med. Res., 44: 361-373.

IRWIN, D., 1931. The anatomy of the Auerbach's plexus. Am. J. Anat., 49: 141-166.

KUMAR, D., PHILLIPS, S.F., 1989. Human myenteric plexus: confirmation of unfamiliar structures in adults and neonates. Gastroenterology, 96: 1021-1028.

LIBERTI, E.A.; DE SOUZA, R.R.; PERITO, M.A.M.; ALVES, N.; CHADI, G, 1994a. Number, size and distribution of ganglion neurons in urinary bladder of rodents. Biol. Res., 27:123-128.

LIBERTI, E.A., QUEIROZ, L.M., POMPEU, E., PERITO, M.A.M., MINARELLI, A.M., MORAES, J.O.R., DE SOUZA, R.R., 1994b. A quantitative comparative study of the ganglionic neurons in the myenteric and submucous plexuses of the small intestine, and in the intramural plexus of the gall bladder of the guinea-pig. Rev. bras. Ciên. morfol, 11 : 106-114. 
LORENZ, J., 1962. Observations comparatives sur l'innervation intramurale du cardia, du pylore et de valvule ileocoecale chez l'homme normal au cours de l'age. Z. Mikrosk. Anat. Forsch., 68: 540-563.

MATSUO, H.A., 1934. A contribution on the anatomy of Auerbach's plexus. Jap. J. Med. Sci. Anat., 4: 417-428.

McLEAN, J.R., BELL, C., BURNSTOCK, G., 1966. Histochemical and pharmacological studies of the innervation of the urinary bladder of the frog (Rana temporaria). Comp. Biochem. Physiol., 21: 383-392.

MECIANO FILHO, J., CARVALHO, V.C., DE-ZOUZA, R.R., 1995. Nerve cell loss in the myenteric plexus of the human esophagus in relation to age: a preliminary investigation. Gerontology, 41: 18-21.

MOSTAFA, F.A., NASSAR, Z.Y., MAHRAN, Z.Y., EL-MAHALLAWI, M.N., 1975. Intrinsec Innervation of the urinary bladder of the kangoroo and albino rats. Acta Anat., 91: 350-361.

MURAT, V.N., 1933. Sur la question de la cytoarchitectonique des ganglions nerveux de líntestin de l'homme. Trab. Lab. Rech. Biol. Univ. Madrid., 28: 387-401.

OHKUBO, K., 1936. Studien über das intramurale nervensystem des verdaungskanals. III. Affe und mensch. Jap. J. Med. Sci. Anat., 6: 219-247.

PALUMBI, G., 1933. Diferentti aspetti del plesso di auerbach in regione dei vari segmenti dell'intestino umano. Ric. Morfol., 13: 538-562.

SCHABADASCH, A., 1930. Die nerven des magens der katze. Z. Zell. Forsch. Mikrosk. Anat., 10: 154.

STERNINI, C., 1988. Structural and chemical organization of the myenteric plexus. Ann. Rev. Phsiol., 50: 81-93.

TAFURI, W.L., 1957. Auerbach's plexus in the guinea-pig. I. A quantitative study of the ganglia and nerve cells in the ileum, caecum and colon. Acta Anat., 31: 522-530.

WELLS, T.R., LANDING, B.H., ARIEL, I, NADORRA, R. GARCIA, C., 1987. Normal anatomy of the myenteric plexus of infants and children. Perpect. Pediatr. Pathol., 1:152-174. 


\begin{tabular}{|c|c|c|c|c|}
\hline 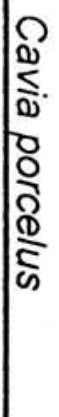 & 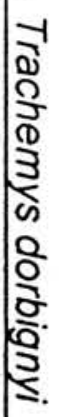 & 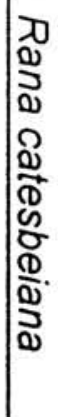 & 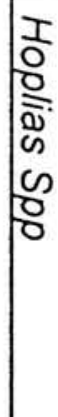 & 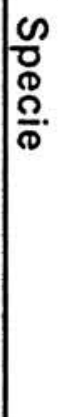 \\
\hline$\frac{N}{D}$ & $\vec{\omega}$ & $\stackrel{N}{ }$ & $\underset{\omega}{\omega}$ & $z$ \\
\hline O & $\vec{\omega}$ & $\frac{\Delta}{N}$ & $\begin{array}{l}\omega \\
\stackrel{0}{\gamma} \\
0\end{array}$ & $\bar{\gamma}$ \\
\hline$\frac{\infty}{\infty}$ & $\vec{N}$ & $\stackrel{N}{A}$ & $\begin{array}{c}\sigma \\
0 \\
\omega\end{array}$ & $\frac{z}{2}$ \\
\hline$\stackrel{N}{\mathcal{O}}$ & $\vec{G}$ & $\infty$ & $\vec{\infty}$ & ( \\
\hline$\stackrel{\infty}{\omega}$ & $N$ & $\omega$ & $\stackrel{N}{V}$ & $\frac{\Omega}{\frac{\Omega}{3}}$ \\
\hline $\mid \begin{array}{l}0 \\
0\end{array}$ & $\stackrel{\Delta}{0}$ & $\stackrel{\Delta}{0}$ & $\underset{\omega}{\omega}$ & $\underset{\Lambda}{z}$ \\
\hline $\begin{array}{l}N \\
\omega \\
\omega\end{array}$ & $\underset{\infty}{\omega}$ & $\begin{array}{l}\Delta \\
\infty \\
\sim\end{array}$ & $\overrightarrow{\vec{\sigma}}$ & 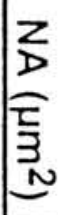 \\
\hline
\end{tabular}



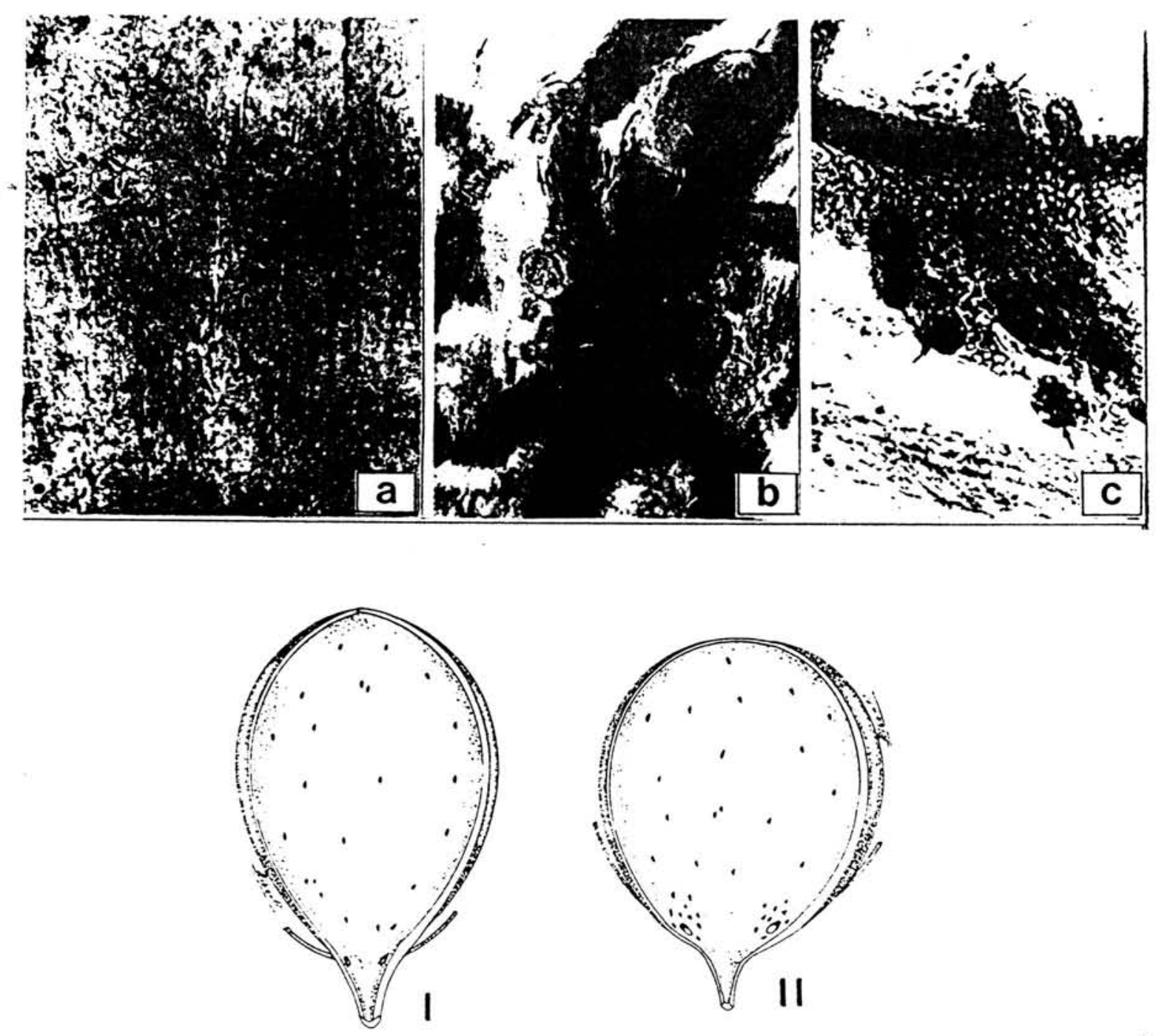


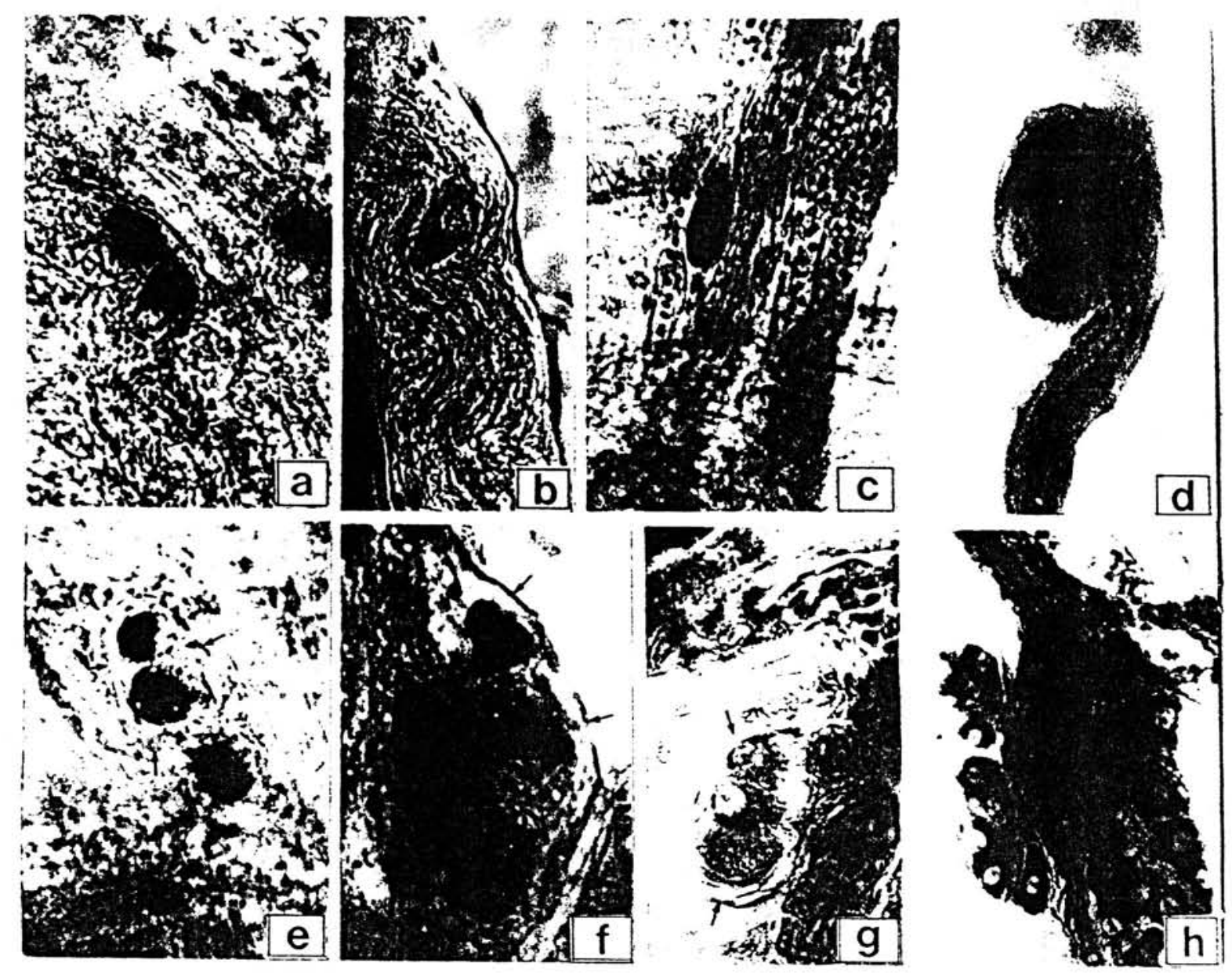

